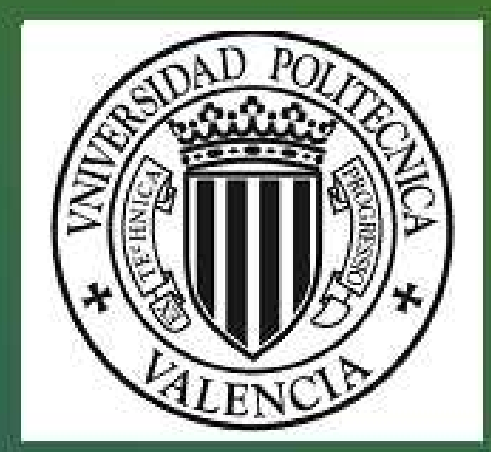

\title{
DESARROLLO DE UN VECTOR PARA LA EXPRESIÓN SIMULTÁNEA DE MÚLTIPLES PROTEÍNAS EN PLANTAS BASADO EN EL POTYVIRUS DEL GRABADO DEL TABACO
}

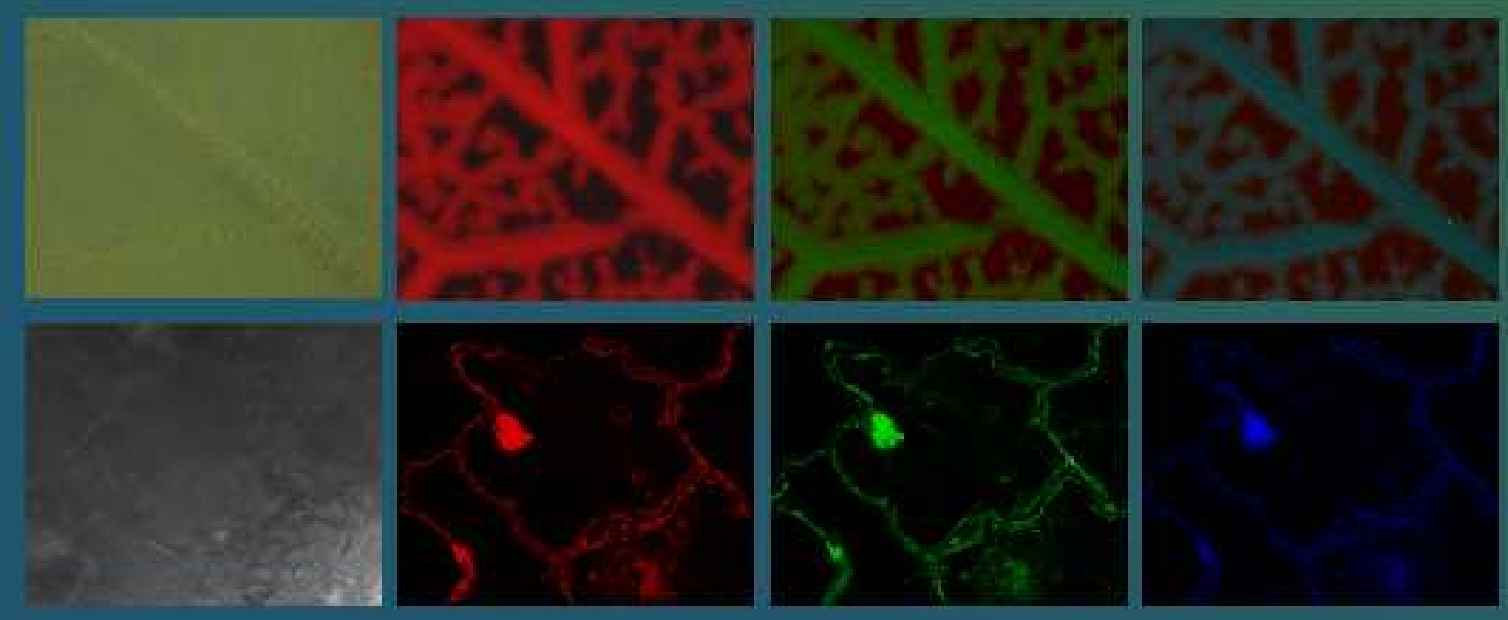

TESIS DOCTORAL

Leonor Cecilia Bedoya Rojas

DIRECTOR

José Antonio Darós Arnau 

A mi familia, fuente de amor y sabiduría 

DESARROLLO DE UN VECTOR PARA LA EXPRESIÓN SIMULTÁNEA DE MÚLTIPLES PROTEÍNAS EN PLANTAS BASADO EN EL POTYVIRUS DEL GRABADO DEL TABACO

MEMORIA DE TESIS DOCTORAL PRESENTADA POR:

Leonor Cecilia Bedoya Rojas

PARA OPTAR AL GRADO DE:

Doctor en Biotecnología por la Universidad Politécnica de Valencia

DIRECTOR:

José Antonio Darós Arnau

UNIVERSIDAD POLITÉCNICA DE VALENCIA

CONSEJO SUPERIOR DE INVESTIGACIONES CIENTÍFICAS

INSTITUTO DE BIOLOGÍA MOLECULAR Y CELULAR DE PLANTAS 

El Dr. José Antonio Darós Arnau, Científico Titular del CSIC, en el Instituto de Biología Molecular y Celular de Plantas (IBMCP, CSIC-Universidad Politécnica de Valencia).

CERTIFICA:

que la Licenciada en Biología LEONOR CECILIA BEDOYA ROJAS ha realizado bajo su dirección en el Instituto de Biología Molecular y Celular de Plantas el trabajo que lleva por título "DESARROLLO DE UN VECTOR PARA LA EXPRESIÓN SIMULTÁNEA DE MÚLTIPLES PROTEÍNAS EN PLANTAS BASADO EN EL POTYVIRUS DEL GRABADO DEL TABACO", y autoriza su presentación para optar al grado de Doctor en Biotecnología.

Y para que así conste y produzca los efectos oportunos donde proceda, expide y firma el presente certificado en Valencia, a 3 de Noviembre de 2011.

Dr. José Antonio Darós Arnau 



\section{AGRADECIMIENTOS}

Durante la realización de mi tesis he tenido la oportunidad de compartir con muchas personas a las cuales me gustaría agradecer, y espero no olvidar a nadie.

En primer lugar tengo que dar mi más profundo agradecimiento a José Antonio Darós, mi director, por haber confiado en mí, haberme dado la oportunidad de incorporarme en su grupo de investigación para desarrollar mi doctorado y por ofrecerme durante todo este tiempo su apoyo y su instrucción. Agradezco enormemente su paciencia, su comprensión con los problemas que se me han presentado en el camino y su ayuda constante e incondicional en mi formación para poder alcanzar este gran logro en mi carrera profesional. No olvidaré la importancia de tener ordenadas tanto las ideas como el sitio de trabajo para poder desarrollar un trabajo satisfactorio.

De forma similar, tengo que plasmar mi agradecimiento a todos los que han sido y son parte del equipo de trabajo en el estratégicamente situado laboratorio 2.05. A los más experimentados, y algunos ya doctores, Jorge Marques, María Ángeles Nohales y Fernando Martínez, por su calurosa acogida inicial y por estar siempre dispuestos a compartir sus conocimientos conmigo y tenerme paciencia en el aprendizaje de las tareas propias del trabajo diario. En este sentido tengo que dar un agradecimiento especial a Fernando por haber participado tan activamente en todo lo referente a mi trabajo de tesis, por su guía y por su actitud abierta y colaboradora. A María Ángeles, de quien admiro su fuerza y disciplina y que ha sido un ejemplo a seguir, y a Jorge desde la distancia desearle lo mejor para la vida y que la vida le devuelva en logros su buen rollo conmigo y su espontánea decencia.

También tengo que incluir a Laura Rubio, cuya estancia fue corta pero fructífera y su aporte a mi trabajo importante, espero que continúe con la experiencia investigadora porque se le da muy bien. $Y$ finalmente, pero no por ello menos importante, las incorporaciones más recientes, la técnico Verónica Aragonés, la doctoranda Eszter Majer y la joven practicante Iris Lodewijk. A ellas un agradecimiento especial por convertirse, más que en compañeras, en amigas y cómplices en el día a día de mi última etapa, y porque sin su compañía, apoyo y ayuda no habría logrado llegar hasta este punto de mi vida. Junto con ellas doy gracias también a Sofía Minoia, del laboratorio de Ricardo Flores, por sus amenas charlas en los pasillos, por regalarme tantos momentos de risas y por dejarme hacer parte de su propia vivencia en el 
instituto. Todas ellas son el fiel reflejo de que la ciencia no tiene por qué reñir con la sencillez, la educación y la amabilidad.

No puede faltar tampoco mi más profundo agradecimiento a quienes dirigen los distintos servicios del instituto y sin los cuales sería imposible sacar adelante cualquier trabajo. No me siento capaz de nombrarlos a todos pero desde Assumpta y Ana Mira, pasando por Marisol, Eugenio y Ramón, incluyendo a los miembros de metabolómica, de genómica y proteómica, así como todos los que hacen parte del grupo de trabajo de los invernaderos. En general, a todo el personal del instituto y a todos los que desarrollan de una $u$ otra forma su trabajo en él, así como a los profesores y compañeros del master, a todos muchas gracias por su ayuda cuando la necesité o simplemente por corresponder un saludo o una sonrisa al cruzarnos en algún pasillo.

En un apartado especial están los agradecimientos a mi familia, ausentes físicamente pero presentes siempre en mi corazón. A mis padres primero que nada, porque sin sus enseñanzas y la idea constante de que solamente estudiando podemos hacer cosas grandes en la vida, no hubiera tenido el impulso y la fuerza para seguir mis sueños. Gracias a su apoyo incondicional en mis ganas un poco locas de hacer ciencia, y gracias por su amor y trabajo con el que pude llegar a ser profesional y arriesgarme a venir a un país desconocido buscando mejorar y aprender un poco más. No podría haber tenido mejores padres, gracias. También a mi hermano y mi hermana y sus familias, que con su cariño me han dado fuerza para seguir adelante. A mi abuela porque es el mejor ejemplo del empuje y la fuerza que tenemos las mujeres. A mi prima Pilar y a César por acompañarme durante una parte de mi experiencia. Muy especialmente agradecer a mi familia política, a mis suegros por acogerme como a una hija y por darme tantas cosas buenas, así como a mis cuñadas y cuñados por su cariño. Gracias a ellos porque nunca me he sentido sola estando lejos de Colombia.

$Y$ finalmente, a mi esposo Santiago, por ser mi compañero de aventuras, por compartir mis sueños y ayudarme a alcanzarlos y por dejarme apoyarlo y ayudarlo a alcanzar los suyos propios. Gracias por tu paciencia, tu apoyo y tu amor en todo momento y por sacrificarte para que pudiera obtener mi doctorado como parte de nuestro proyecto de vida conjunto. Te amo y espero que podamos estar juntos siempre recorriendo este camino, porque caminar contigo a mi lado hace que todo parezca posible. $Y$ ahora somos una familia completa, gracias por darme el regalo de ser mamá que es una de las alegrías más grandes de la vida. Los adoro a nuestro bebé y a ti, y son la fuerza para despertar cada día con esperanza y sin miedo por lo que vendrá. 


\section{ÍNDICE}

ABREVIATURAS

RESUMEN

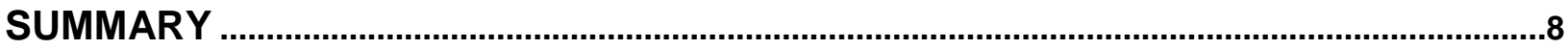

RESUM

CAPÍTULO 1. INTRODUCCIÓN GENERAL .......................................................................14

1. LAS PLANTAS COMO BIOFACTORÍAS ................................................. 15

2. LOS VIRUS COMO VECTORES DE EXPRESIÓN DE PROTEÍNAS ...................20

3. CLONES INFECCIOSOS DE VIRUS .....................................................29

4. SUPRESORES VIRALES DEL SILENCIAMIENTO INDUCIDO POR RNA ..........32

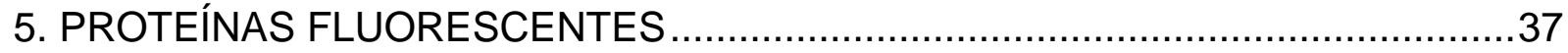

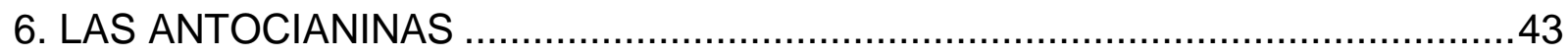

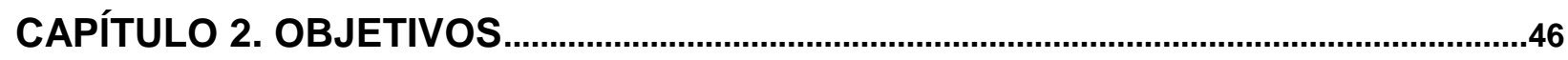

CAPÍTULO 3. RESULTADOS: CONSTRUCCIÓN DE CLONES INFECCIOSOS Y ESTABLES DEL VIRUS DEL GRABADO DEL TABACO (TEV).............................................48

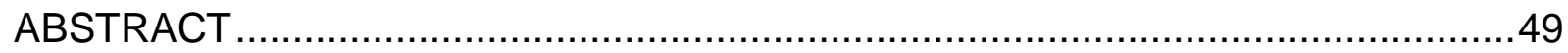

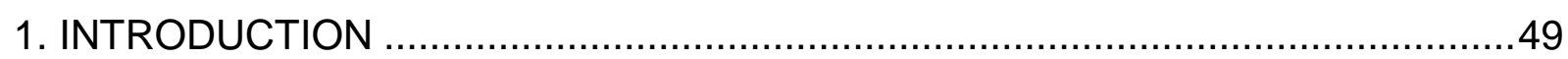

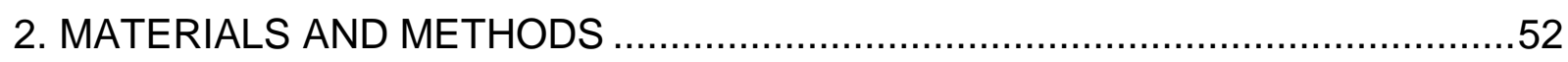

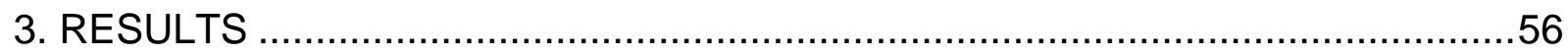

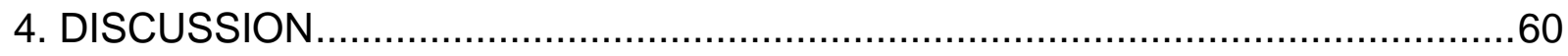

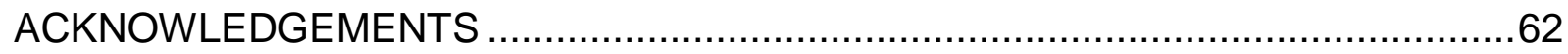

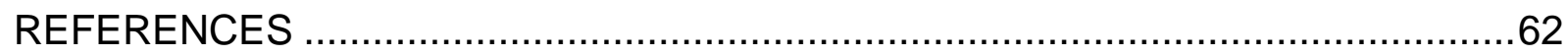

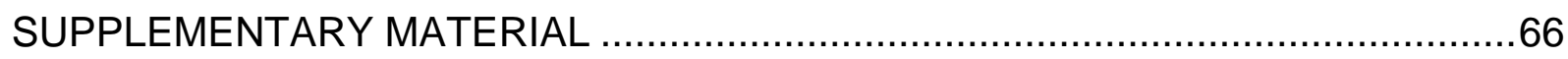


CAPÍTULO 4. RESULTADOS: CONSTRUCCIÓN DE UN VECTOR VIRAL DESARMADO PARA LA EXPRESIÓN SIMULTÁNEA DE MÚLTIPLES PROTEÍNAS, BASADO EN EL VIRUS DEL GRABADO DEL TABACO (TEV) ………........................................................72

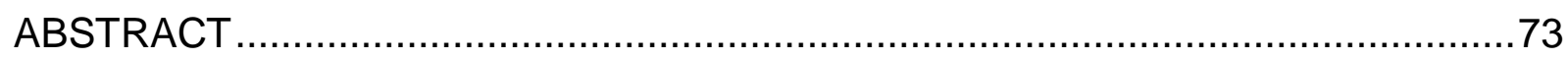

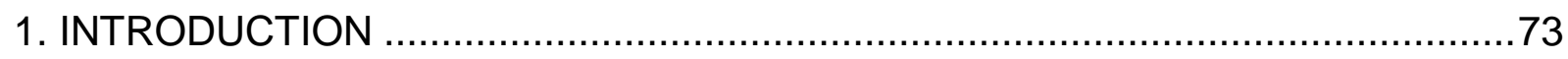

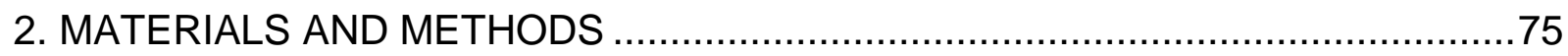

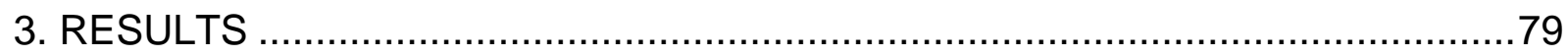

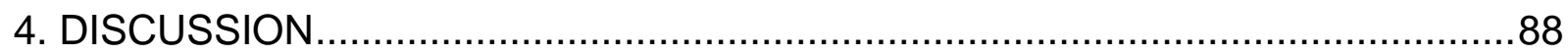

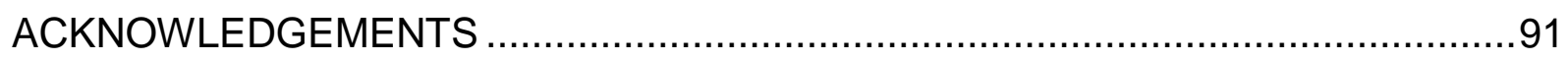

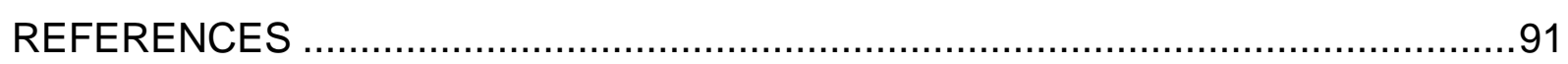

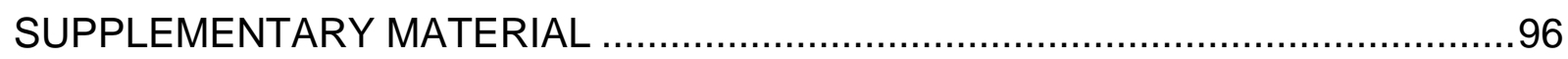

CAPÍTULO 5. RESULTADOS: SUPLEMENTACIÓN DEL VECTOR DE EXPRESIÓN BASADO EN EL TEV CON UN SUPRESOR VIRAL ADICIONAL DEL SILENCIAMIENTO

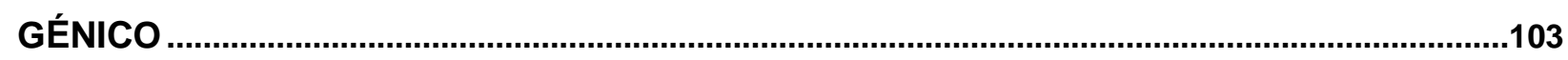

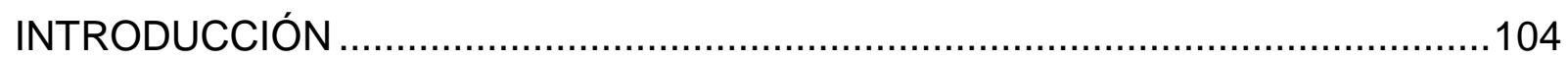

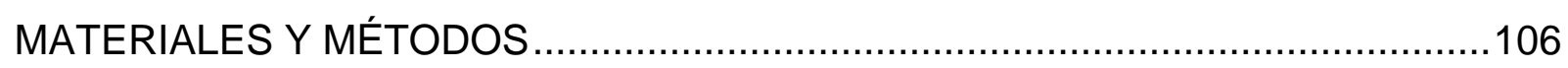

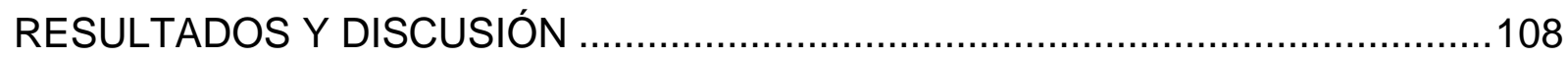

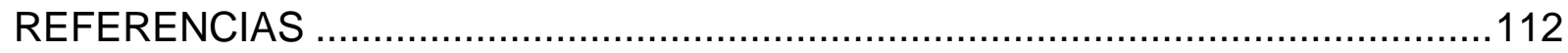

CAPÍTULO 6. RESULTADOS: DECONSTRUCCIÓN DEL VECTOR DE EXPRESIÓN BASADO EN EL POTYVIRUS DEL GRABADO DEL TABACO ..............................................116

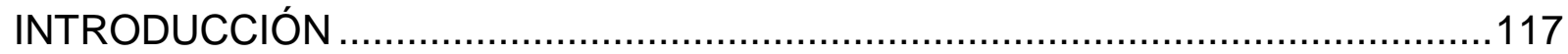

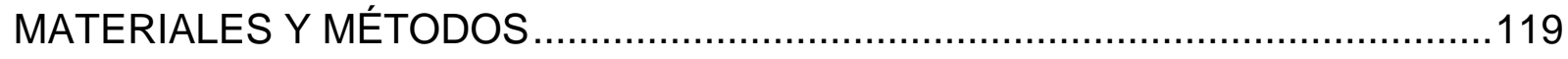

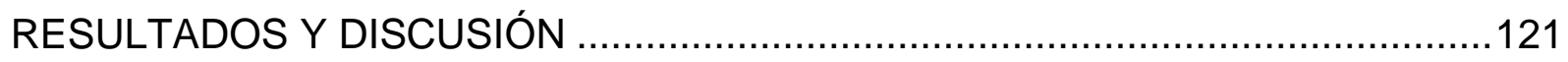

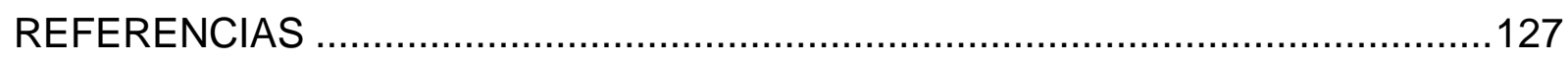

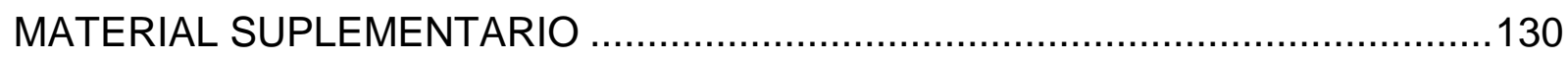

CAPITULO 7. RESULTADOS: ROSEA1 COMO MARCADOR VISUAL PARA SEGUIR LA INFECCIÓN Y MOVIMIENTO DE VIRUS EN PLANTAS.........................................................131

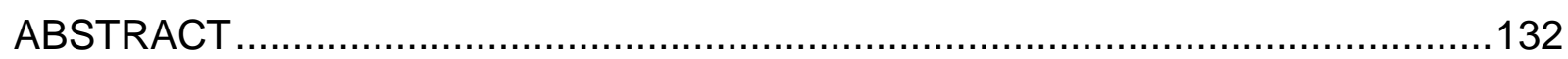

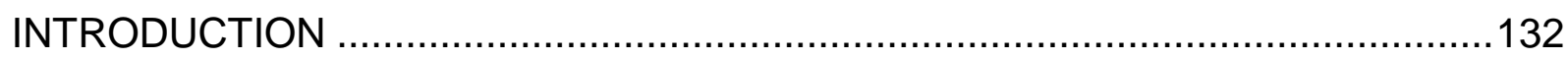


RESULTS 134

DISCUSSION

MATERIALS AND METHODS 145

ACKNOWLEDGEMENTS 147

REFERENCES 147

SUPPLEMENTARY MATERIAL 153

CAPÍTULO 8. DISCUSIÓN GENERAL 162

CONCLUSIONES 172

BIBLIOGRAFÍA .175 
ABREVIATURAS 
AGO: argonaute protein, proteína Argonauta.

BAC: bacterial artificial chromosome, cromosoma artificial bacteriano.

BFP: blue fluorescent protein, proteína fluorescente azul.

BMV: Brome mosaic virus, virus del mosaico del bromo.

BSMV: Barley stripe mosaic virus, virus del mosaico estriado de la cebada.

BWYV: Beet western yellows virus, virus del amarilleo occidental de la remolacha.

BYV: Beet yellows virus, virus del amarilleo de la remolacha.

CaMV: Cauliflower mosaic virus, virus del mosaico de la coliflor.

CAT: chloramphenicol acetyltransferase, cloranfenicol acetiltransferasa.

cDNA: complementary DNA, DNA complementario.

$\mathrm{CHI}$ : chalcone isomerase, chalcona isomerasa.

CHS: chalcone synthase, chalcona sintasa.

CMV: Cucumber mosaic virus, virus del mosaico del pepino.

CP: coat protein, proteína de cubierta o de la cápside.

CPMV: Cowpea mosaic virus, virus del mosaico del chícharo.

CTV: Citrus tristeza virus, virus de la tristeza de los cítricos.

CYIVV: Clover yellow vein virus, virus del amarilleo del trébol.

DCL: dicer-like RNAse III, RNAsa de tipo III dicer-like.

Del: Delila.

DHFR: dihydrofolate reductase, dihidrofolato reductasa.

DNA: deoxyribonucleic acid, ácido desoxirribonucléico.

DO: densidad óptica.

DRB: double stranded RNA-binding protein, proteína de unión a RNA de doble cadena.

DsRed: Dicosoma red fluorescent protein, proteína fluorescente roja de Dicosoma.

dsRNA: double stranded RNA, RNA de doble cadena.

EGFP: enhanced green fluorescent protein, proteína fluorescente verde mejorada.

EYFP: enhanced yellow fluorescent protein, proteína fluorescente amarilla mejorada.

FLIP: fluorescence loss in photobleaching, pérdida de fluorescencia en fotobleaching.

FMDV: Foot-and-mouth disease virus, virus de la fiebre aftosa.

FPs: fluorescent proteins, proteínas fluorescents.

FRAP: fluorescence recovery after photobleaching, recuperación de la fluorescencia después del fotobleaching.

FRET: fluorescence resonance energy transfer, transferencia de energía de resonancia fluorescente. 
GFP: green fluorescent protein, proteína fluorescente verde.

GUS: beta glucuronidasa.

HC-Pro: viral helper component-protease, componente ayudante-proteasa viral.

HIV: Human immunodeficiency virus, virus de la inmunodeficiencia humana.

HPV: Human papilloma virus, virus del papiloma humano.

kb: kilobase.

miRNA: micro RNA, micro RNA.

MP: movement protein, proteína de movimiento.

NPTII: neomycin Phosphotransferase II, neomicina fosfotransferasa II.

ORF: open reading frame, pauta de lectura abierta.

ORSV: Odontoglossum ringspot virus, virus de la mancha anillada del Odontoglossum.

PCR: polymerase chain reaction, reacción en cadena de la polimerasa.

PEDV: Porcine epidemic diarrea virus, virus de la diarrea epidémica porcina.

PPV: Plum pox virus, virus de la sharka de los frutales de hueso.

PSbMV: Pea seedborne mosaic virus, virus del mosaico del guisante.

PSTVd: Potato spindle tuber viroid, viroide del tubérculo fusiforme de la patata.

PVA: Potato virus $A$, virus $A$ de la patata.

PVV: Potato virus $V$, virus $V$ de la patata.

PVX: Potato virus $X$, virus $X$ de la patata.

PVY: Potato virus $Y$, virus $Y$ de la patata.

PTGS: post-transcriptional gene silencing, silenciamiento génico postranscripcional.

RdRP: RNA-dependent RNA polymerase, RNA polimerasa RNA-dependiente.

RFP: red fluorescent protein, proteína fluorescente roja.

RISC: RNA-induced silencing complex, complejo de silenciamiento inducido por RNA.

RNA: ribonucleic acid, ácido ribonucléico.

Ros1: Rosea1.

RT-PCR: reverse transcription-PCR, transcripción reversa-PCR.

sRNA: small RNA, RNA pequeño.

siRNA: small interfering RNA, pequeño RNA interferente.

ssRNA: single stranded RNA, RNA monocaternario o de simple cadena.

TBSV: Tomato bushy stunt virus, virus del enanismo arbustivo del tomate.

TCV: Turnip crinkle virus, virus del arrugamiento del nabo.

TEV: Tobacco etch virus, virus del grabado del tabaco.

TGEV: Transmissible gastroenteritis virus, virus transmisible de la gastroenteritis. 
TMV: Tobacco mosaic virus, virus del mosaico del tabaco.

TRV: Tobacco rattle virus, virus del cascabeleo del tabaco.

TuMV: Turnip mosaic virus, virus del mosaico del nabo.

TVMV: Tobacco vein mottling virus, virus del moteado de las venas del tabaco.

TYLCV: Tomato yellow leaf curl virus, virus del rizado amarillo del tomate.

UTR: untranslated region, región no traducible.

VIGS: virus-induced gene silencing, silenciamiento inducido por virus.

WSMV: Wheat streak mosaic virus, virus del mosaico estriado del trigo.

YFP: yellow fluorescent protein, proteína fluorescente amarilla.

ZYMV: Zucchini yellow mosaic virus, virus del mosaico amarillo del calabacín. 


\section{RESUMEN}

El uso de plantas como biofactorías se ha propuesto como una opción sencilla, económica y más segura para la producción biotecnológica de proteínas heterólogas y otros productos de aplicación en medicina o industria. Asímismo, los virus de vegetales pueden ser una herramienta muy eficiente para la obtención de dichos productos, gracias a su facilidad natural de infectar, invadir las plantas y expresar su información genética eficientemente. Entre ellos se encuentra el virus del grabado del tabaco ( Tobacco etch virus, TEV), un virus de RNA de cadena positiva de la familia Potyviridae ampliamente empleado en estudios sobre biología molecular de virus de plantas e interacciones planta-patógeno. Basándose en un clon infeccioso de este virus, en el presente estudio se ha desarrollado un vector viral desarmado que permite la expresión simultánea de múltiples proteínas heterólogas en plantas.

Puesto que el único clon infeccioso de este virus disponible era inestable durante su amplificación en bacterias como Escherichia coli, como primera etapa para el desarrollo del vector de expresión, se diseñaron y construyeron tres nuevos plásmidos con el mismo clon infeccioso del TEV que permitieran infectar plantas con RNA transcrito in vitro (pMTEV), directamente con DNA (p35TEV) o por agroinoculación (pGTEV). En su construcción se eliminaron las secuencias consideradas superfluas en los plásmidos correspondientes y se orientaron los distintos elementos funcionales de forma lógica para aumentar la estabilidad del cDNA viral durante su propagación en bacterias. Los tres nuevos plásmidos resultaron mucho más estables que el ancestral y permitieron infectar eficientemente plantas de tabaco mediante RNA transcrito, directamente con DNA plasmídico o por agroinoculación.

El vector de expresión se construyó sobre la base del plásmido para agroinoculación pGTEV. En el vector, el cistrón viral que codifica la RNA polimerasa RNA dependiente (proteína Nlb) se reemplazó por un casete que contenía los cDNAs de las distintas proteínas heterólogas a expresar. Estos cDNAs fueron flanqueados por las secuencias correspondientes a sitios de corte naturales y artificiales de la proteasa viral NlaPro para asegurar el correcto procesamiento de las proteínas heterólogas de la poliproteína viral. Se construyeron varias versiones del vector de expresión, entre las que destacan el vector que expresa tres proteínas fluorescentes, roja (mCherry), amarilla (Venus) y 
azul (mTagBFP), y el que expresa dos factores de transcripción de Antirrhinum majus (Delila y Rosea1) de la ruta de biosíntesis de las antocianinas. Al inocular plantas de tabaco (Nicotiana tabacum) transgénicas, que suplementan la función Nlb a través de un transgén, se detectó la expresión colocalizada de las tres proteínas fluorescentes tanto a nivel de tejido como subcelular. También se comprobó el eficiente procesamiento de cada proteína heteróloga a partir de la poliproteína viral. Finalmente, se comprobó que el vector que carece del cistrón de su RNA polimerasa es incapaz de infectar plantas en las que esta función no es suplementada, lo que supone un importante elemento de biocontención de la tecnología. En el caso de la expresión de los dos factores de transcripción que activan la biosíntesis de antocianinas, la inoculación de las plantas transgénicas que expresan Nlb provocó una fuerte acumulación de estos compuestos en los tejidos infectados por el virus que adquirieron una fuerte coloración rojiza. Estos resultados avalan la utilidad del nuevo vector para expresar proteínas heterooligoméricas que requieren un correcto ensamblado de sus múltiples componentes y en ingeniería metabólica de plantas.

A continuación, para mejorar los niveles de expresión de las proteínas heterólogas a partir del vector viral basado en el TEV, se analizó el efecto de insertar un segundo supresor viral del silenciamiento inducido por RNA. Los resultados sobre un vector que expresa la proteína fluorescente roja mCherry mostraron que la coexpresión de la proteína P19 del virus del enanismo arbustivo del tomate (TBSV) aumenta la expresión en aproximadamente un 50\%, y la proteína $2 \mathrm{~b}$ del virus del mosaico del pepino (CMV) la aumenta un $20 \%$. En contraste, la proteína $16 \mathrm{~K}$ del virus del cascabeleo del tabaco (TRV) no tiene ningún efecto, mientras que la proteína HC-Pro de otro potyvirus, el virus de la sharka de los frutales de hueso, tiene un efecto negativo. En una segunda estrategia para mejorar el vector de expresión desarmado basado en el TEV, se estudio qué otros cistrones del genoma del virus podrían transferirse a la planta huésped. Utilizando una estrategia de expresión transitoria en plantas de Nicotiana benthamiana, se identificaron nuevos cistrones que se podrían eliminar del vector y ser suplementados en trans, lo que mejorará la capacidad de albergar información genética heteróloga por parte del vector.

Finalmente, los estudios de expresión de factores de transcripción de la ruta de las antocianinas llevaron al desarrollo de un nuevo sistema para seguir visualmente la 
dinámica de un proceso de infección viral en plantas. El sistema se basa en la expresión del factor de transcripción Rosea1 (Ros1) de 25.7 kDa que induce la acumulación de antocianinas coloreadas en los tejidos por los que el virus se replica y mueve. La cantidad de pigmento rojo se observó que correlacionaba con la carga viral, por lo que el marcador resultó ser cuantitativo. Además, este marcador mostró ser muy estable durante pases infectivos seriados en plantas de tabaco. Además de la infección del TEV en plantas de tabaco, el marcador mostró ser útil para seguir la infección del potyvirus del mosaico del nabo en plantas de Arabidopsis thaliana y del virus del mosaico del tabaco o el virus $X$ de la patata en plantas de $N$. benthamiana. 


\section{SUMMARY}

The use of plants as biofactories has been proposed as an easy, economical and safe option for the biotechnological production of heterologous proteins and other products for use in medicine or industry. Likewise, plant viruses can be a very efficient tool for the production of these products, thanks to its natural capacity to infect, invade the plants and efficiently express their genetic information. Among them, it is Tobacco etch virus (TEV), a positive strand RNA virus of the family Potyviridae widely used in studies on molecular biology of plant viruses and plant-pathogen interactions. Based on an infectious clone of this virus, this study has developed a disarmed viral vector that allows the simultaneous expression of multiple heterologous proteins in plants.

Since the only available infectious clone of this virus was unstable during amplification in bacteria such as Escherichia coli, in the first step towards the development of the expression vector, three new plasmids were designed and constructed with the same TEV infectious clone that allowed infecting plants with in vitro transcribed RNA (pMTEV), directly with DNA (p35TEV) or by agroinoculation (pGTEV). In the construction, sequences considered redundant were eliminated in the corresponding plasmids and the various functional elements were directed in a logical way to increase the stability of the viral cDNA during propagation in bacteria. The three new plasmids were much more stable than the ancestral and allowed infecting plants efficiently through transcribed RNA, directly with plasmid DNA or by agroinoculation.

The expression vector was constructed based on the plasmid for agroinoculation pGTEV. In the vector, the viral cistron encoding the RNA-dependent RNA polymerase (protein Nlb) was replaced by a cassette containing the cDNAs of different heterologous proteins to be expressed. These cDNAs were flanked by sequences corresponding to natural and artificial cleavage sites of viral protease NlaPro to ensure the proper processing of the heterologous proteins from the viral polyprotein. Several versions of the expression vector were constructed, among which are the vector expressing three fluorescent proteins, red (mCherry), yellow (Venus) and blue (mTagBFP), and another expressing two transcription factors (Delila and Rosea1) from Antirrhinum majus biosynthetic pathway of anthocyanins. When inoculating transgenic tobacco plants (Nicotiana tabacum), which supplement the Nlb function through a transgene, the col- 
localized expression of the three fluorescent proteins was detected both at tissue and subcellular level. The efficient processing of each heterologous protein from the viral polyprotein was also observed. Finally, it was proved that the vector that lacks the RNA polymerase cistron is unable to infect plants in which this function is not supplemented, which is an important component of biocontainment for the technology. In the case of expression of the two transcription factors that activate anthocyanin biosynthesis, the inoculation of transgenic plants expressing Nlb caused a strong accumulation of these compounds in tissues infected with the virus that acquired a strong reddish color. These results support the usefulness of the new vector to express heterooligomeric proteins that require a proper assembly of its multiple components and in plant metabolic engineering.

Next, to improve the expression levels of the heterologous proteins from the viral vector based on the TEV, the effect of inserting a second viral suppressor of RNA-induced silencing was analyzed. The results on a vector expressing the red fluorescent protein mCherry showed that co-expression of the P19 protein from Tomato bushy stunt virus (TBSV) increases the expression by approximately $50 \%$, and the $2 \mathrm{~b}$ protein from Cucumber mosaic virus (CMV) increases it by $20 \%$. In contrast, the $16 \mathrm{~K}$ protein from Tobacco rattle virus (TRV) has no effect, whereas the HC-Pro protein from another potyvirus, Plum pox virus (PPV), has a negative effect. In a second strategy to improve the disarmed expression vector based on the TEV, the transfer of other cistrons of the viral genome to the host plant was studied. Using a transient expression strategy in Nicotiana benthamiana plants, new cistrons were identified that could be eliminated from the vector and supplemented in trans were, which will improve the vector capacity to accommodate heterologous genetic information.

Finally, the studies about transcription factors from the anthocyanin pathway led to the development of a new system to visually track the dynamics of a viral infection process in plants. The system is based on the expression of the transcription factor Rosea1 (Ros1) of $25.7 \mathrm{kDa}$ that induces colored anthocyanin accumulation in the tissues where the virus replicates and moves. The amount of red pigment was observed to correlate with viral load, so that the marker was found to be quantitative. In addition, this marker was shown to be very stable during serial infective passages in tobacco plants. In addition to TEV infection in tobacco plants, the marker was shown to be helpful in 
tracking the infection of turnip mosaic potyvirus in Arabidopsis thaliana plants and Tobacco mosaic virus or Potato virus $X$ in $N$. benthamiana plants. 


\section{RESUM}

La utilització de plantes com a biofactories s'ha proposat com una opció senzilla, econòmica i mes segura per a la producció biotecnològica de proteïnes heteròlogues $\mathrm{i}$ d'altres productes d'aplicació en medicina i industria. Tanmateix, els virus de vegetals poden ser una ferramenta molt eficient per a la obtenció d'estos productes, gràcies a la facilitat natural d'infectar, envair les plantes i expressar la seua informació genètica eficientment. Entre ells es troba el virus del gravat del tabac (Tobacco etch virus, TEV), un virus d'RNA de cadena positiva de la família Potyviridae amplament empleat en estudis sobre la biologia molecular de virus de plantes e interaccions planta-patogen. Basant-se en un clon infecciós d'este virus, en el present estudi s'ha desenvolupat un vector viral desarmat que permet l'expressió simultània de múltiples proteïnes heteròlogues en plantes.

Donat que l'únic clon infecciós disponible d'este virus era inestable durant la seua amplificació en bactèries com Escherichia coli, com a primera etapa per al desenvolupament del vector d'expressió, es dissenyaren i construïren tres nous plasmidis amb el mateix clon infecciós del TEV que permeteren infectar plantes amb RNA transcrit in vitro (pMTEV), directament amb DNA (p35TEV) o per agroinoculació (pGTEV). En la seua construcció s'eliminaren les seqüències considerades supèrflues en els plasmidis corresponents i s'orientaren els distints elements funcionals de forma lògica per a augmentar l'estabilitat del cDNA viral durant la seua propagació en bacteris. Els tres nous plasmidis resultaren molt mes estables que l'ancestral $i$ permeteren infectar eficientment plantes de tabac mitjançant RNA transcrit, directament amb DNA plasmídic o per agroinoculació.

El vector d'expressió es va construir sobre la base del plasmidi per a agroinoculació pGTEV. En el vector, el cistró que codifica la RNA polimerasa RNA depenent (proteïna $\mathrm{Nlb)}$ es va reemplaçar per un casset que contenia els cDNAs de les distintes proteïnes heteròlogues a expressar. Estos cDNAs foren flanquejats per les seqüencies corresponents a llocs de tall naturals i artificials de la proteasa viral NlaPro per a assegurar el correcte processament de les proteïnes heteròlogues a partir de la poliproteïna viral. Es construïren varies versions del vector d'expressió, entre les que destaquen el vector que expressa tres proteïnes fluorescents, roja (mCherry), groga 
(Venus) i blava (mTagBFP), i el que expressa dos factors de transcripció d'Antirrhinum majus (Delila i Rosea1) de la ruta de biosíntesi d'antocianines. Al inocular plantes de tabac (Nicotiana tabacum) transgèniques, que suplementen la funció Nlb a través d'un transgèn, es va detectar l'expressió colocalitzada de les tres proteïnes fluorescents tant a nivell de teixit com subcel.lular. També es va comprovar l'eficient processament de cada proteïna heteròloga a partir de la poliproteïna viral. Finalment, es va comprovar que el vector al qui li manca el cistró de la seua RNA polimerasa es incapaç d'infectar plantes en les que la funció no es suplementada, la qual cosa suposa un important element de biocontenció de la tecnologia. En el cas de l'expressió dels dos factors de transcripció que activen la biosíntesi d'antocianines, la inoculació de les plantes transgèniques que expressen Nlb va provocar una forta acumulació d'estos compostos en els teixits infectats per el virus que van adquirir una forta coloració vermella. Estos resultats avalen la utilitat del nou vector per a expressar proteïnes heterooligomèriques que requereixen un correcte encoblament dels seus múltiples components i en enginyeria metabòlica de plantes.

A continuació, per a millorar els nivells d'expressió de les proteïnes heteròlogues a partir del vector viral basat en el TEV, es va analitzar el efecte d'inserir un segon supressor viral del silenciament induït per RNA. Els resultats sobre un vector que expressa la proteïna fluorescent roja mCherry van mostrar que la coexpressió de la proteïna P19 del virus del nanisme arbustiu de la tomata (TBSV) augmenta l'expressió en aproximadament un $50 \%$, i la proteïna $2 \mathrm{~b}$ del virus del mosaic del cogombre (CMV) la augmenta un $20 \%$. En contrast, la proteïna $16 \mathrm{~K}$ del virus del cascavelleig del tabac (TRV) no té ningun efecte, mentre que la proteïna HC-Pro d'un altre potyvirus, el virus de la sharka de la pruna, té un efecte negatiu. En una segona estratègia per a millorar el vector d'expressió desarmat basat en el TEV, es va estudiar quins altres cistrons del genoma del virus podrien transferir-se a la planta hoste. Utilitzant una estratègia d'expressió transitòria en plantes de Nicotiana benthamiana, es van identificar nous cistrons que es podrien eliminar del vector i ser suplementats en trans, la qual cosa millorarà la capacitat d'albergar informació genètica heteròloga per part del vector.

Finalment, els estudies d'expressió de factors de transcripció de la ruta de les antocianines portaren al desenvolupament d'un nou sistema per a seguir visualment la dinàmica d'un procés de infecció viral en plantes. El sistema es basa en la expressió 
del factor de transcripció Rosea1 (Ros1) de 25.7 kDa que indueix la acumulació d'antocianines acolorides en els teixits en els que el virus es replica i es mou. La quantitat de pigment roig es va observar correlacionada amb la càrrega viral, per el que el marcador va resultar ser quantitatiu. A demés, este marcador va mostrar ser molt estable durant passes infectius seriats en plantes de tabac. A demés de la infecció del TEV en plantes de tabac, el marcador va mostrar ser útil per seguir la infecció del potyvirus del mosaic del nap en plantes d'Arabidopsis thaliana i del virus mosaic del tabac o el virus $X$ de la creïlla en plantes de $N$. benthamiana. 
CAPÍTULO 1:

INTRODUCCIÓN GENERAL 


\section{LAS PLANTAS COMO BIOFACTORIAS}

El progreso de la biología molecular y la ingeniería genética ha permitido el desarrollo de distintos sistemas biológicos para la obtención de proteínas recombinantes como anticuerpos, vacunas humanas y animales, hormonas, componentes sanguíneos, enzimas industriales y biopolímeros (Dyck et al., 2003; Basaran y Rodríguez-Cerezo, 2008; Ezure et al., 2010; Jeong et al., 2011). Uno de los primeros y más usados sistemas de producción de proteínas es el de bacterias como Escherichia coli (ampliamente estudiada tanto para investigación básica como aplicada), Pseudomonas spp., Serratia marcescens, Erwinia herbicola o Lactococcus lactis. Aunque crecen rápidamente y pueden originar altas concentraciones de un producto, las bacterias no tienen un sistema de modificaciones postraduccionales lo que dificulta la obtención de proteínas grandes correctamente plegadas y además pueden producir endotoxinas que contaminen las proteínas producidas (Demain y Vaishnav, 2009). Los hongos y las levaduras como Saccharomyces cerevisiae, Pichia y Hansenula son también un prometedor sistema de expresión debido a su capacidad de modificación de proteínas y relativamente altas tasas de producción. De igual forma, algunos mohos como Trichoderma y Aspergilli se han usado por sus altos niveles de expresión. Sin embargo, a pesar de sus ventajas pueden tener problemas de inestabilidad en sistemas de producción a gran escala o un incorrecto procesamiento postraduccional de las proteínas haciéndolas inactivas (Gerngross, 2004). Las células de insectos aparecieron como una posibilidad para expresar proteínas desde que Smith et al., en 1983, produjeron interferón $\beta$ humano en una línea de células derivadas del lepidóptero Spodoptera frugiperda, usando un baculovirus como vector. Con esta aproximación aunque existe la ventaja de contar con un sistema de modificaciones que permite producir proteínas de mamíferos complejas, a menudo dicho sistema no es suficientemente eficiente y se pueden obtener proteínas incorrectamente procesadas (Rai y Padh, 2001). Como alternativa para la producción de muchas proteínas de aplicación terapéutica, como anticuerpos monoclonales o vacunas, se han desarrollado variadas líneas celulares de mamíferos que permiten obtener proteínas correctamente procesadas y activas. Entre ellas se encuentran las células de ovario de hámster chino $(\mathrm{CHO})$, las células de riñón de hámster sirio (BHK), hibridomas, células de mieloma de ratón (NSO), células de riñón de mono verde africano (Vero) o células de retinoblasto fetal humano (Per.C6). Una de las principales desventajas de esta aproximación es el alto costo en recursos y tiempo que conlleva el establecimiento y mantenimiento de 
dichas líneas celulares, además de la posibilidad de contaminación con patógenos (Bisbee, 1993). Asimismo, se están desarrollando animales transgénicos como ratones, vacas, cerdos, conejos, ovejas y cabras, para la producción de proteínas recombinantes principalmente a través de la leche (Clark, 1998). En este caso, frente a las ventajas evidentes de poder obtener proteínas activas y más parecidas a las originales (generalmente humanas), hay desventajas que incluyen los altos costos, el largo tiempo de producción, los altos requerimientos técnicos y tecnológicos, las posibilidades de contaminación de los animales con patógenos humanos y los factores éticos propios de manipular este tipo de material (Mahmoud, 2007).

Frente a todas las vías de producción de proteínas recombinantes anteriormente descritas, las plantas se presentan como un sistema alternativo con un gran potencial. La biotecnología vegetal se propuso, como primer objetivo, mejorar y aumentar la producción agrícola para la alimentación de una población mundial creciente, pero dos importantes descubrimientos han permitido el avance en este campo y la ampliación de sus metas a muchas otras áreas de la investigación. El primero fué que a partir de una sola célula vegetal se puede regenerar una planta entera idéntica genéticamente a esa primera célula (Steward et al., 1958). El segundo, que se puede transferir un gen foráneo al DNA de una planta por medio de la bacteria fitopatógena Agrobacterium tumefaciens aprovechando su mecanismo natural de infección, es decir, la transmisión de genes desde su plásmido Ti (T-DNA) hasta el genoma vegetal, con vectores binarios diseñados especialmente con este propósito (De Block et al., 1984).

Las plantas son un sistema óptimo de expresión y ofrecen diversas ventajas en comparación con bacterias, hongos o células animales. Su mantenimiento es fácil y menos costoso, ya que básicamente solo necesitan agua, sol y nutrientes. El escalado de la producción, la extracción del producto final y el almacenamiento y transporte, además de económicos, suelen ser más fáciles y rápidos (Daniell et al., 2001). Cuentan naturalmente con la capacidad de compartimentalizar y almacenar de forma estable proteínas en determinados órganos, y un sistema de expresión de proteínas y de modificaciones postraduccionales de las mismas, como la glicosilación o el plegamiento, muy eficiente y similar al de animales y humanos, lo que permite obtener proteínas recombinantes correctamente estructuradas y activas. Tienen un muy bajo riesgo de contaminación con patógenos o endotoxinas, presentes en sistemas 
animales y bacterianos, que puedan afectar los productos destinados a uso humano, y no suscitan los problemas éticos asociados al manejo de material animal (Shih y Dorán, 2009). Finalmente, algunas proteínas producidas en sistemas vegetales, como por ejemplo vacunas, pueden usarse mediante el consumo directo de las plantas, eliminando la necesidad de extracción y purificación o requiriendo únicamente un procesamiento simple y económico (Desai et al., 2010).

En general, existen dos métodos para producir proteínas heterólogas en plantas: la transformación nuclear o de plastidios y la transformación transitoria (Fig. 1.1). En cualquier caso, el objetivo suele ser que las proteínas se expresen en hojas o en órganos de almacenamiento como semillas y, en determinadas ocasiones, que la información genética sea heredable (Mett et al., 2008). La transformación genética estable de plantas es un método que se ha extendido considerablemente desde los primeros casos exitosos, por ejemplo cuando Fraley et al. (1983) lograron transformar protoplastos obtenidos de hojas de petunia con genes marcadores y de selección utilizando $A$. tumefaciens, y comprobaron su correcta expresión en tejido calloso. También existen ejemplos como la expresión de la hormona de crecimiento humano (hGH) en callos transformantes de tabaco y girasol (Barta et al., 1986), de seroalbúmina humana (HSA) en plantas transgénicas de tabaco y patata (Sijmons et al., 1990), la obtención del primer anticuerpo funcional (IgG) en 1989 en plantas de tabaco transgénicas (Hiatt et al., 1989), o la obtención en maíz de productos como avidina, $\beta$-glucuronidasa (GUS) y tripsina (Hood, 2002). Aunque la transformación mediada por Agrobacterium tumefaciens suele ser la opción más común, también se han desarrollado otros métodos para insertar genes en el genoma nuclear de las plantas como la microinyección, la biobalística, la electroporación, o la transformación mediada por polietilenglicol (PEG), si bien ninguno de ellos parece ser igual de eficiente (Meyers et al., 2010). Asimismo, además de la transformación nuclear se puede realizar la transformación genética estable del genoma de plastidios, principalmente el cloroplasto. En este caso, la introducción del gen foráneo se realiza por recombinación homóloga y, al contrario de lo que ocurre con la transformación nuclear, se conoce con exactitud el sitio de la inserción. Por el modo de transmisión de los cloroplastos es un sistema contenido, se pueden acumular grandes cantidades de proteínas, y se evitan los posibles problemas de posicionamiento de los genes introducidos y el silenciamiento génico (Daniell et al., 2002). Existen ejemplos de transformación del 
cloroplasto en plantas cultivadas para mejorar alguna característica agronómica, como resistencias a factores bióticos y abióticos. Igualmente se ha estudiado su utilidad para la expresión de proteínas de aplicación en medicina como insulina, interferones, somatotropina, antígenos para vacunas contra enfermedades bacterianas, virales o de protozoos, y en la industria para producir biopolímeros, aminoácidos o enzimas industriales (Verma y Daniell, 2007). Por otro lado, para la producción de proteínas recombinantes también se puede realizar la expresión transitoria en plantas, en la cual no se introduce una característica heredable. Este método ofrece la ventaja de ser mucho más rápido que la transformación genética, un proceso largo y de grandes requerimientos técnicos por haber una etapa in vitro obligatoria, la posibilidad de obtener mayores concentraciones de proteínas, al evitarse muchos de los problemas relacionados con la inserción de genes en el genoma vegetal como el silenciameinto, y evitar el debate suscitado sobre la obtención y uso de plantas transgénicas (Kapila et al., 1997). La expresión transitoria puede realizarse en general por agroinfiltración o por medio de la infección con virus vegetales modificados. En el primer caso, un cultivo de A. tumefaciens recombinante conteniendo el vector con el gen a expresar se infiltra, usualmente en las hojas de las plantas, por vacío o por inyección directa. De este modo, dentro del área infiltrada y en las células en cuyo núcleo se ha insertado el TDNA de la bacteria, unos pocos días después ocurre la transcripción y la expresión del gen foráneo. Esta técnica permite obtener cantidades suficientes de proteínas para estudiar la utilidad de diversas construcciones, o para la misma caracterización de las proteínas heterólogas obtenidas, y hace posible la expresión simultánea de múltiples genes o de genes de gran tamaño en la zona infiltrada (Fischer y Emans, 2000). Uno de los principales problemas que se pueden presentar con la agroinfiltración es que el silenciamiento génico postranscripcional (PTGS) disminuya o elimine la expresión de las proteínas recombinantes en un corto tiempo, aunque en algunos casos la coinoculación con supresores del silenciamiento virales ha permitido contrarrestar este proceso (Johansen y Carrington, 2001; Álvarez et al., 2008). Otra posibilidad para expresar transitoriamente proteínas en plantas es por medio de vectores virales. Esta es una metodología mucho más rápida, fácil y flexible que la transformación genética, con la que se pueden obtener niveles de expresión en comparación mucho más altos y es aplicable a una potencialmente amplia gama de plantas en los estadios más convenientes de su desarrollo (Pogue et al., 2002). 


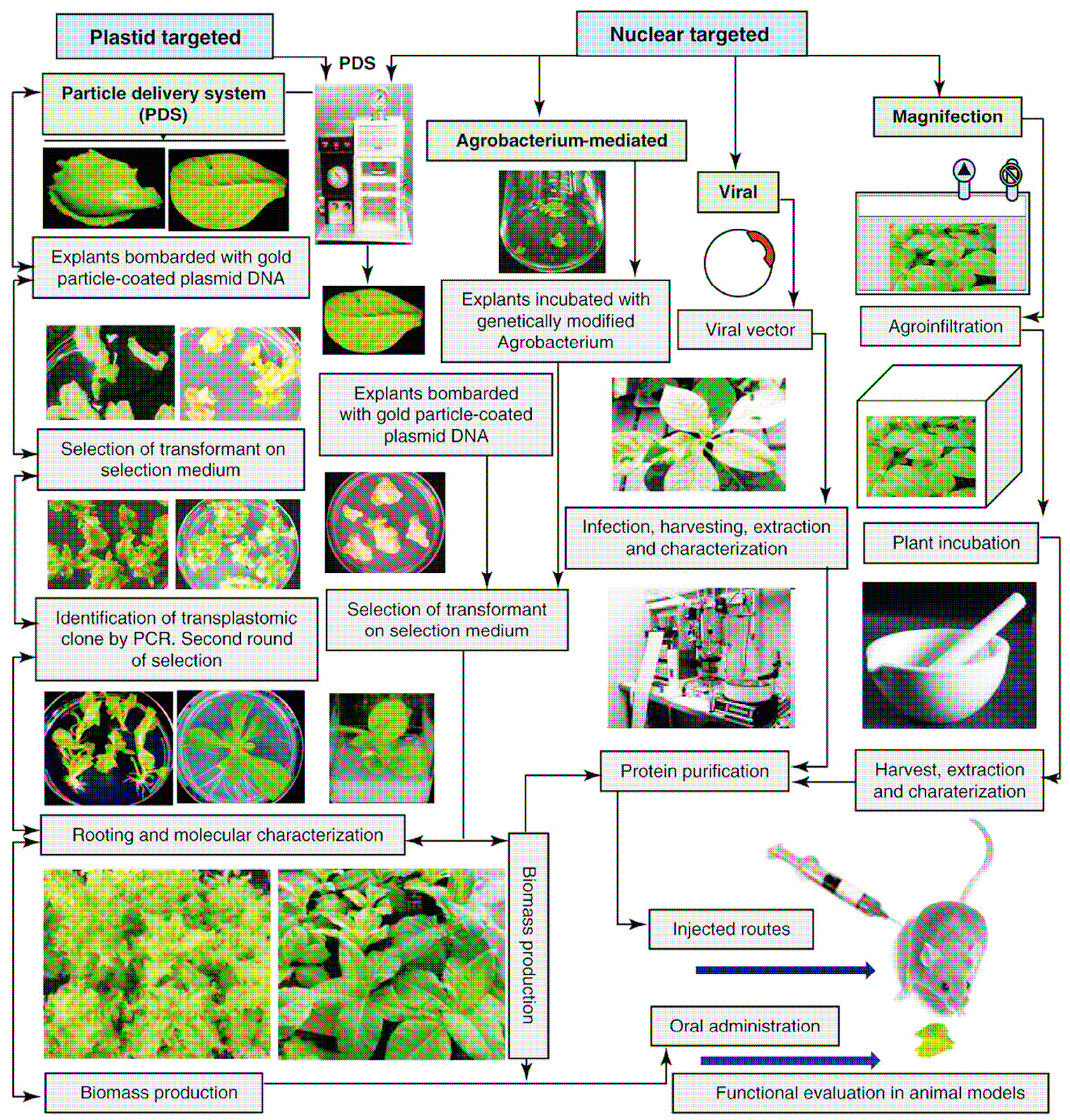

Figura 1.1. Representación esquemática del proceso de producción de antígenos, vacunas o biofármacos en plantas y su evaluación funcional en modelos animales. Los explantes son tejidos con potencial de regeneración en plantas y como ejemplos de plantas se muestra la lechuga y el tabaco. Tomado de Daniell et al., 2009.

Finalmente, existe una larga lista de plantas y sistemas vegetales que se han usado para producir proteínas recombinantes de distintas aplicaciones, siendo muy común el empleo de especies como Nicotiana benthamiana, Nicotiana tabacum o Arabidopsis thaliana. También plantas de patata, tomate, maíz, arroz, zanahoria, algunas pocas especies frutales no arbóreas, e incluso algas, ya sea como plantas completas, en semillas, en cultivos celulares o para la transformación de cloroplastos (Rybicki, 2010). 


\section{LOS VIRUS COMO VECTORES DE EXPRESIÓN DE PROTEÍNAS}

Los virus vegetales han representado históricamente un problema y, debido al gran número de enfermedades que causan en cultivos de importancia mundial, han sido estudiados principalmente como patógenos causantes de grandes pérdidas económicas. Sin embargo, la investigación básica y aplicada avanzan a un ritmo cada vez mayor, hay un auge actual de la biotecnología y se han desarrollado herramientas clave, como los sistemas de vectores binarios basados en el uso de la bacteria Agrobacterium tumefaciens (Komori et al, 2007), lo cual ha hecho cambiar las perspectivas de estos patógenos. Las interacciones que los virus establecen con sus plantas huésped han dado una oportunidad para su uso en áreas como el estudio a nivel molecular de las infecciones virales, la expresión de proteínas heterólogas en sistemas vegetales o el desarrollo de vectores para estudios de silenciamiento genético inducido por virus (virus-induced gene silencing, VIGS) (Ratcliff et al., 2001; Zhang et al., 2010), entre otros.

En lo referente a su aplicación en la obtención de proteínas heterólogas, los virus vegetales son adecuados vectores de expresión porque debido a sus genomas relativamente pequeños su manipulación genética in vitro es casi rutinaria, lo que permite obtener variadas construcciones en un tiempo considerablemente corto, la infección mecánica o por agroinoculación de plantas es simple y rápida, y la purificación de las proteínas a partir del tejido vegetal sencilla (Cañizares et al., 2005). Asimismo, una de las principales características que los hacen atractivos para su uso a nivel biotecnológico, es que los virus son capaces de alterar y utilizar a su favor toda la maquinaria molecular de las células vegetales infectadas, en funciones como la replicación, la transcripción y la traducción, para multiplicarse rápidamente y moverse sistémicamente a lo largo de toda la planta. Este hecho posibilita que un gen foráneo insertado en el genoma viral se exprese y acumule de forma similar a otros genes virales, es decir, en cantidades potencialmente altas, durante el relativamente corto lapso de tiempo en que se establece y extiende la infección viral, en tejidos vegetales variados como hojas, tallos y raíces, y en un virtualmente amplio espectro de plantas según sea la gama de huéspedes del virus empleado (Scholthof et al., 1996).

Existen distintas aproximaciones para la construcción de vectores virales, los cuales se introducen en las plantas por medio de transcritos infecciosos o por agroinoculación, y 
que se pueden dividir en tres grupos generales (Fig. 1.2). En primer lugar se encuentra la presentación de epítopos en las partículas virales, descrita por Johnson et al. (1997). Esta metodología se usa para la producción de antígenos y el desarrollo de vacunas contra diversas enfermedades humanas o animales, y consiste en la expresión de péptidos fusionados a la proteína de la cápside viral, en la superficie de los viriones completos. Debido al alto número de copias de la proteína de cubierta en una partícula viral, los epítopos se pueden acumular en grandes cantidades en plantas donde se ha producido la infección viral sistémica y se pueden extraer fácilmente. Para realizar este tipo de estudios es importante conocer detalladamente a nivel molecular y genético el genoma viral y, especialmente, la secuencia y características de la proteína de la cápside $(\mathrm{CP})$, para realizar la inserción o fusión del péptido en una región donde no se alteren las funciones de ensamblaje y movimiento virales. Dentro de los virus que se han usado para la expresión de epítopos uno de los más frecuentes es el virus del mosaico del tabaco (Tobacco mosaic virus, TMV), que tiene como principal ventaja su altísima capacidad de acumularse en los tejidos vegetales permitiendo la obtención de grandes cantidades de proteínas recombinantes. Hamamoto et al. (1993) presentaron uno de los primeros ejemplos de vectores basados en el TMV para expresar un péptido inhibidor de la enzima convertidora de angiotensina (ACEI). Dicho péptido tiene aplicación en el tratamiento de enfermedades cardiacas e hipertensión, y se produjo en plantas de tabaco y de tomate fusionado a la región C-terminal de la CP viral. En todos los casos el virus pudo moverse sistémicamente y expresar tanto el péptido fusionado a la CP como la CP sola en las partículas virales, incluso en los frutos de tomate. Asimismo, con el TMV se han expresado con éxito epítopos de la malaria en plantas de tabaco (Turpen et al., 1995), la hemaglutinina del virus de la influenza y una proteína de cubierta del virus de la inmunodeficiencia humana (Human immunodeficiency virus, HIV) tipo I (Sugiyama et al., 1995), y un péptido derivado de la proteína de la cápside del poliovirus tipo I, que produjo inmunización en ratones (Fujiyama et al., 2006). También se han empleado otros virus en este tipo de estudios, como el virus $X$ de la patata (Potato virus $X, \mathrm{PVX}$ ) para expresar la proteína fluorescente verde GFP (green fluorescent protein de Aequorea victoria) (Santa Cruz et al., 1996), el virus del enanismo arbustivo del tomate (Tomato bushy stunt virus, TBSV) para expresar parte de una glicoproteína del HIV (Joelson et al., 1997) o el virus del mosaico del caupí (Cowpea mosaic virus, CPMV) (Liu et al., 2005). Un segundo sistema de expresión consiste en introducir un gen foráneo en el genoma del virus completo y que mantenga 
todas sus funciones intactas. Esto significa añadir información genética al virus mientras este conserva su capacidad de infectar las células vegetales, replicarse y moverse sistémicamente a lo largo de toda la planta en un tiempo de 2 a 3 semanas (Gleba et al., 2004). Para virus en los que se expresan genes por medio de mRNAs subgenómicos, la construcción de vectores se puede hacer añadiendo un promotor subgenómico adicional (Chapman et al., 1992), mientras que para otro tipo de virus el gen de interés se puede clonar en pauta con un marco abierto de lectura existente (open reading frame, ORF), junto con secuencias que permitan su procesamiento (Hagiwara et al., 1999).

El mantener intacta toda la información necesaria para que el virus sea completamente funcional y desempeñe correctamente todos sus procesos es una ventaja. Sin embargo, pueden presentarse problemas por las limitaciones sobre la cantidad de material genético exógeno que se puede insertar, como el incorrecto ensamblaje de las partículas virales, la inestabilidad y pérdida del inserto, una reducida gama de plantas huésped, una evolución más lenta de la infección o la baja acumulación de la proteína recombinante por problemas en la replicación o el movimiento célula a célula y de larga distancia dentro de la planta (Gleba et al., 2007). Algunas posibles soluciones se han enfocado en la manipulación de las secuencias de los promotores subgenómicos (Shivprasad et al., 1999), la mejora genética de algunas proteínas virales relevantes como la proteína de movimiento (movement protein, MP) (Toth et al., 2002), o incluso el intercambio de algunos genes entre distintos virus para ampliar su gama de huéspedes (Wu y Zhou, 2002). En tercer y último lugar, existe la posibilidad de construir vectores virales en los que se ha sustituido algún gen viral por el gen de la proteína recombinante. Esta metodología busca contrarrestar los problemas impuestos por el límite de tamaño para la inserción de genes en los vectores, y que algunas de las funciones virales no esenciales se puedan eliminar o trasladar a otros sistemas para suplementarlas en trans. Además, dentro de este grupo se incluyen todas las técnicas de deconstrucción y modificación genética que permiten crear vectores virales más eficientes en la acumulación de proteínas heterólogas y en los que se pueda insertar genes de mayor tamaño (Gleba et al., 2007). Como ejemplo se puede nombrar el trabajo de Sainsbury y Lomonossoff (2008), en el que para aumentar la cantidad de expresión de las proteínas recombinantes eliminaron el codón AUG de la posición 161 de la porción 5' del RNA-2 del CPMV (que contiene los genes de la proteína de 
movimiento y de cubierta) y sustituyeron desde la posición 512 en adelante con distintas proteínas heterólogas. Encontraron que proteínas fluorescentes como la GFP o la DsRed (red fluorescent protein de Discosoma) se pueden acumular en plantas de Nicotiana benthamiana a concentraciones de hasta 1,6 g por cada kg de tejido fresco, mientras que otras como el antígeno central de la hepatitis $\mathrm{B}$ (Hepatitis $B$ core antigen, HBcAg) o el anticuerpo anti-HIV humano 2 G12 pueden acumularse en hasta $1 \mathrm{~g}$ o 325 mg por kg de tejido fresco, respectivamente. También se encuentra el sistema descrito por Gleba et al. en 2005, llamado "Magnifection", desarrollado por la compañía alemana Icon Genetics. Este sistema de expresión de proteínas consiste básicamente en la infiltración de distintas partes de plantas maduras con cultivos diluidos de $A$. tumefaciens que contienen en su T-DNA un replicón de un RNA viral. De este modo, la bacteria es la encargada de la infección primaria y sistémica de la planta, mientras que el vector viral mantiene las funciones de movimiento célula a célula, amplificación y expresión, lo cual permite alcanzar altísimos niveles de acumulación de proteínas.

Representative Virus

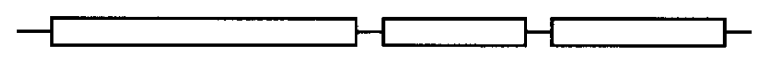

Gene Replacement

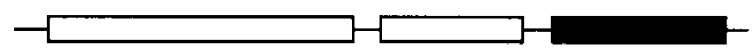

Gene Insertion

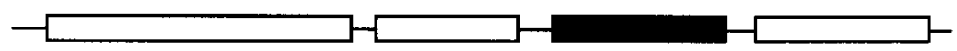

Epitope Presentation

Complementation

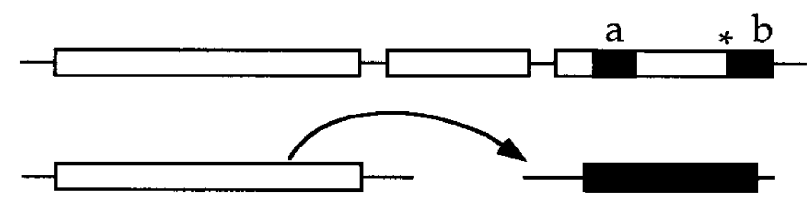

Gene Replacement

Bromovirus

Caulimovirus

Furovirus

Geminivirus

Hordeivirus

Potexvirus

Tobamovirus

Tobravirus

Epitope Presentation Complementation

Gene Insertion

Comovirus

Caulimovirus

Tobamovirus

Alfamovirus

Geminivirus

Tombusvirus

Caulimovirus

Potexvirus

Potyvirus

Tobamovirus

Dianthovirus

Geminivirus

Potexvirus

Tobamovirus

Tombusvirus

Tombusvirus

Figura 1.2. Representación esquemática de 4 distintas formas de expresar proteínas heterólogas en plantas por medio de vectores virales: reemplazo de genes virales, inserción de genes de interés en el genoma viral completo, presentación de pequeños epítopos o complementación con otros vectores. En la parte inferior se enumeran algunos de los grupos de virus empleados en cada tipo de estrategia. Tomado de Scholthof et al., 1996. 
En lo referente a los tipos de virus vegetales que se pueden utilizar como vectores, estos se pueden dividir en tres grupos. El primero, está compuesto por virus cuyo genoma es una doble cadena de DNA, y a este pertenecen los caulimovirus y los badnavirus. El virus del mosaico de la coliflor (Cauliflower mosaic virus, CaMV) pertenece a los primeros y, en 1984, se usó como vector para expresar en plantas el gen bacteriano de la dihidrofolato reductasa (dhfr), en sustitución del gen viral para la transmisión por insectos, y así conferir resistencia al metotrexato (Brisson et al., 1984). Sin embargo, a pesar de este y otros intentos, estos virus no parecen ser buenos vectores de expresión ya que solo permiten la inserción de genes pequeños y tienen una gama de plantas huésped estrecha (Gronenborn and Matzeit, 1989). Un segundo grupo es el de los geminivirus, compuesto por los géneros mastrevirus, curtovirus, topocuvirus y begomovirus, que pueden infectar un amplio número de plantas mono y dicotiledóneas. Su pequeño genoma, de entre 2,5 y 3 kilobases (kb), está compuesto por DNA de cadena sencilla que puede ser mono o bipartito, y su replicación ocurre en el núcleo de las células vegetales infectadas a través de un DNA intemediario de doble cadena (Gutierrez et al., 2004). Stanley (1993) describe algunos ejemplos de miembros de este grupo que se han usado como vectores de expresión, reemplazando el gen de la CP por algún gen foráneo. Aunque se han logrado infectar plantas y expresar genes de interés, parece que existen limitaciones impuestas por el tamaño final del vector, además del papel crucial que puede jugar la CP en replicación o movimiento. En tercer lugar se encuentra el grupo más amplio, del que forman parte los virus con genoma de RNA. Aunque hay algunos de doble cadena de RNA o de simple cadena y sentido negativo, los más abundantes y estudiados son los virus de cadena sencilla y sentido positivo [ssRNA(+)]. A ese grupo pertenecen tanto virus isométricos como virus alargados y flexuosos con forma de varilla. En los primeros hay diversas familias como Bromoviridae, Tombusviridae, Luteoviridae o Tymoviridae y subfamilias como Comovirinae (Fauquet et al., 2005). Aunque algunos miembros de estas familias se han estudiado como vectores de expresión de genes reporteros como GUS o el de la cloranfenicol acetiltransferasa (CAT), posiblemente debido a su estructura y conformación hay una gran inestabilidad de los genes insertados y limitaciones de tamaño (French et al., 1986). Por otro lado, están los virus de ssRNA (+) con forma de varilla, un grupo amplio y variado cuyos miembros se han usado más extensamente como vectores de expresión por ser mucho más flexibles a la inserción de material genético exógeno en su genoma. Dentro de estos hay familias como Potyviridae, 
Closteroviridae o miembros del género Tymovirales y destacan géneros como Tobamovirus, cuyo miembro principal es el virus del mosaico del tabaco (TMV), Potexvirus, como PVX o Potyvirus, que infectan una amplia gama de plantas en todo el mundo (Scholthof et al., 1996).

Con respecto a los potyvirus, estos pertenecen a la familia Potyviridae, conforman uno de los géneros de virus más numeroso de los descritos, y se encuentran distribuidos en todo el mundo como patógenos de una amplia gama de plantas mono y dicotiledóneas, muchas de ellas de importancia agronómica, hortícola u ornamental. Representan aproximadamente el $30 \%$ de todos los virus de plantas y están relacionados con los comovirus y nepovirus de vegetales y con los picornavirus de animales por características relativas a la estructura del genoma y algunas secuencias proteicas (Ward y Shukla, 1991). Son transmitidos por áfidos de forma no persistente y por semillas. Las partículas virales tienen forma de varilla, son flexuosas, sin envoltura y de 700-750 nm de longitud, conteniendo una copia del genoma viral. Este consiste en RNA de cadena sencilla y sentido positivo de aproximadamente $10 \mathrm{~kb}$, con regiones terminales no traducibles (UTRs), una proteína VPg unida covalentemente en 5' y una cola poliA en 3' (Riechmann et al., 1992). Poseen una pauta de lectura abierta (ORF) principal, de la que se obtiene una poliproteína, por traducción no dependiente de cap, que se procesa en al menos 10 proteínas maduras por la acción de tres proteasas virales distintas que forman parte de la misma poliproteína (Urcuqui-Inchima et al., 2001), y además existe una segunda pauta solapante recientemente descrita de la que se deriva la proteína P3N-PIPO (Chung et al., 2008). Los potyvirus, y más concretamente el virus del grabado del tabaco (Tobacco etch virus, TEV) han sido ampliamente empleados como virus modelo para el estudio básico de factores relacionados con la infección, como los elementos de la transmisión por áfidos (Fernández-Calvino et al., 2010), la replicación y movimientos virales (Cui et al., 2010), así como de las relaciones e interacciones que se establecen entre el virus y su planta huésped a nivel molecular (Ala-Poikela et al., 2011). Además de dichos estudios básicos, estos virus también se han utilizado para expresar en plantas genes foráneos de diferentes tipos. Por ejemplo, con el virus del mosaico amarillo del calabacín (Zucchini yellow mosaic virus, ZYMV) se ensayó la expresión de un epítopo inmunogénico del virus de la fiebre aftosa insertado en el área amino terminal de la proteína de la cápside (evaluando variadas deleciones dentro de la misma), y se ha 
comprobado que dicha región no es necesaria para el movimiento sistémico viral (Arazi et al., 2001a). Asimismo, con una cepa atenuada de este virus se ha probado la expresión del gen del interferón alfa-2 humano en plantas de calabaza y pepino (Arazi et al., 2001b), y también la adquisición de resistencia a herbicidas que contienen glufosinato de amonio en plantas de melón, pepino, calabaza y sandía gracias a la expresión del gen bar, que codifica para la fosfinotricina acetiltransferasa (Shibolet et al., 2001). Con construcciones basadas en el virus del mosaico estriado del trigo (Wheat streak mosaic virus, WSMV), el virus tipo de los Tritimovirus, se lograron expresar genes reporteros, como GUS o el de resistencia a la kanamicina (neomicina fofotransferasa, NPTII) en plantas de trigo y maíz, mostrando su posible aplicación en plantas monocotiledóneas (Choi et al., 2000). Se han insertado genes de proteínas heterólogas en un vector basado en el virus de la sharka de los frutales de hueso (Plum pox virus, PPV), para formar un cistrón independiente entre el gen de la replicasa (NIb) y el de la proteína de cubierta (CP), que se procesa gracias al sitio de procesamiento natural entre los dos genes virales y la adición de un sitio artificial de reconocimiento de la proteasa Nla viral en la región amino terminal. Con dicho vector se ha expresado la proteína estructural VP60 del virus de la enfermedad hemorrágica del conejo (Rabbit hemorrhagic disease vius, RHDV) en plantas de Nicotiana clevelandii, con cuyos extractos se logró obtener respuesta inmune a dicho virus en conejos (FernándezFernández et al., 2001). Genes reporteros como GFP o GUS se han usado para estudiar el mejor sitio de inserción dentro del genoma viral, medir la eficiencia de expresión y ensayar la posibilidad de insertar y expresar simultáneamente más de un gen. Ejemplos de ello son vectores basados en el virus del mosaico del nabo (Turnip mosaic virus, TuMV) (Beauchemin et al., 2005), el TEV (Dolja et al., 1992), el virus del amarilleo del trébol (Clover yellow vein virus, CYIVV) (Masuta et al., 2000) y el virus A de la patata (Potato virus A, PVA) (Kelloniemi et al., 2008).

Desde un punto de vista histórico, los primeros virus en desarrollarse como vectores de expresión alrededor de 1980 fueron aquellos con genomas de DNA (Brisson et al., 1984), ya que solamente estos se podían manipular genéticamente. Sin embargo, los virus de DNA poseen complejos sistemas de replicación y, además, la mayoría de virus de plantas tienen genomas de RNA de una cadena y sentido positivo, que tienen amplias gamas de huéspedes y pueden llegar a alcanzar muy altas concentraciones en las plantas que infectan. Con la obtención del primer clon de cDNA completo e 
infeccioso del virus del mosaico del bromo (Brome mosaic virus, BMV) por Ahlquist et al. (1984), se inició el desarrollo de los virus de RNA como vectores para su uso en expresión de secuencias foráneas, o como herramientas para el estudio del silenciamiento génico, ya que sus genomas relativamente pequeños hacen que sean más fáciles de manipular en el laboratorio mediante genética reversa para el diseño y construcción de los vectores de expresión deseados (Wagner et al., 2004). Además, al clonar las secuencias virales bajo la acción de promotores como el $35 \mathrm{~S}$ del CaMV, es posible crear clones directamente infecciosos como DNA. Otro avance técnico importante fue el empleo de Agrobacterium tumefaciens para promover la infección viral en las plantas que, al contrario de la inoculación mecánica con RNA o DNA, facilita una inserción directa y muy eficiente del cDNA viral en el núcleo de las células vegetales, y también permite la agroinfección con virus no transmitidos mecánicamente (Grimsley et al., 1986).

Los primeros vectores virales se construyeron reemplazando el gen de la CP por otros genes. Este es el caso de la inserción del gen cloranfenicol acetiltransferasa (CAT) en el genoma del TMV con largas deleciones en la CP (Takamatsu et al, 1987), de lo genes GUS y CAT reemplazando la CP del TBSV (Scholthof et al, 1993) o del gen de la GFP en el virus del arrugamiento del nabo (Turnip crinkle virus, TCV) (Cohen et al., 2000) Sin embargo, en la mayoría de ocasiones aunque los vectores funcionaban correctamente en protoplastos y en plantas se desarrollaban síntomas y se expresaban los genes reporteros a nivel local en las hojas inoculadas, no se observaba infección sistémica, o si esta ocurría los genes insertados se perdían rápidamente. Este hecho mostró que para muchos virus vegetales la proteína de cubierta puede jugar un papel crucial para el movimiento y otras funciones virales (Takamatsu et al, 1987; Scholthof et al, 1993; Cohen et al., 2000). A partir de allí, se inició el desarrollo de vectores virales en los que los genes heterólogos se insertaban en reemplazo de algún gen viral o en el genoma completo para no afectar ninguna función vital. En el segundo caso, ya que dicha inserción se traduce en un mayor tamaño, este tipo de aproximaciones se ha enfocado a virus que forman partículas alargadas, los cuales tienen una mayor flexibilidad para empaquetar genomas agrandados. A pesar del alto número de virus vegetales que existen, la construcción de vectores de expresión en plantas se ha enfocado principalmente en unos pocos. Tal vez el que ocupa el primer lugar es el TMV, un virus con un genoma de RNA de menos de $7 \mathrm{~kb}$ que codifica para cuatro 
proteínas, dos de las cuales se traducen a partir de RNAs subgenómicos. Una de las características que lo hacen atractivo es la capacidad de acumular su CP en hasta un $10 \%$ del peso fresco de tejido vegetal infectado (Yusibov et al., 1999). Para superar los problemas de reemplazar la CP del TMV por otro gen, anteriormente descritos, Donson et al. (1991) construyeron un vector utilizando un promotor subgenómico, y la proteína de la CP, del virus de la mancha anillada del Odontoglossum (Odontoglossum ringspot virus, ORSV). Con esta metodología se pudieron expresar los genes de la hidrofolato reductasa (DHFR) y de la neomicina fosfotransferasa II (NptII), gracias al correcto movimiento sistémico del virus, en plantas de $N$. benthamiana. Así, comenzaron a expresarse otro tipo de genes utilizando vectores basados en el TMV. Por ejemplo, el gen de la proteína inactivadora de ribosomas alfa-tricosantina, usada en estudios sobre el HIV, se expresó en plantas de $N$. benthamiana alcanzando una concentración de hasta el $2 \%$ de las proteínas solubles (Kumagai et al., 1993). También se expresaron las cadenas pesada y ligera del anticuerpo monoclonal (mAb) C017-1A, usado contra un antígeno del cáncer de colon, en dos vectores separados y coinfiltrados en $N$. benthamiana, que permitió detectar el anticuerpo correctamente ensamblado y funcional (Verch et al., 1998). Wigdorovitz et al. (1999) obtuvieron respuesta inmune en ratones después de inyectarles un extracto foliar obtenido de plantas infectadas con un vector de expresión del TMV conteniendo la proteína VP1, un factor inmunogénico del virus de la fiebre aftosa (Foot and mouth disease virus, FMDV). Asimismo, usando el TMV como vector se han podido expresar la FSH (follicle stimulating hormone), una glucoproteína producida por mamíferos en la glándula pituitaria (Dirnberger et al., 2001), un epítopo (COE) del virus de la diarrea epidémica porcina (Porcine epidemic diarrea virus, PEDV) en niveles de hasta $5 \%$ de todas las proteínas solubles (Kang et al., 2004), o el gen L1 del virus del papiloma humano tipo 16 (Human papillomavirus, HPV-16) (Varsani, 2006), entre otros.

Un segundo virus ampliamente usado como vector de expresión de proteínas recombinantes es PVX, el miembro tipo de los potexvirus. De forma similar a lo ocurrido con el TMV, uno de los primeros ensayos mostró que el reemplazo del gen de la CP con el gen GUS bacteriano impedía el movimiento sistémico del virus en plantas de $N$. tabacum cv. Samsun NN o Nicotiana clevelandii, mientras que al situar ese mismo gen dentro del genoma viral completo bajo la acción de una copia del promotor subgenómico de la CP viral, el virus pudo moverse sistémicamente y expresar GUS 
adecuadamente, aunque con una estabilidad media (Chapman et al., 1992). Posteriormente, en 1995, Baulcombe et al. obtuvieron resultados similares al expresar la proteína verde GFP en plantas de Nicotiana clevelandii. A pesar de la relativamente baja estabilidad de algunas construcciones realizadas con este virus, se han expresado distintas proteínas, como fragmentos variables de cadena sencilla (simple-chain variable fragment, $\mathrm{scFv}$ ) contra la $\mathrm{CP}$ del virus $\mathrm{V}$ de la patata (Potato virus $\mathrm{V}, \mathrm{PVV}$ ) (Hendy et al., 1999) o la proteína estructural VP6 de un rotavirus murino (Epizootic diarrhea of infant mice, EDIM) de forma libre y como una fusión a la proteína de cubierta en plantas de $N$. benthaminana (O'Brien et al., 2000). También se han expresado con éxito por medio del PVX el gen de la defensina WT1 de Wasabia japónica, con actividad antimicrobiana y antifúngica, en plantas de $N$. benthamiana (Sahito et al., 2001), la proteína de la nucleocápside del virus de la hepatitis B (HBcAg) (Mechtcheriakova et al., 2006) y la proteína E7 del HPV-16 fusionada en 5' o 3' a la CP (Plchova et al., 2011), además de sus aplicaciones en estudios de genética funcional y de silenciamiento génico (Verchot-Lubicz et al., 2007). En tercer lugar se sitúa el CPMV, miembro de los comovirus, cuyo genoma consiste en dos moléculas separadas de RNA, y que siguen una estrategia de expresión mediante una poliproteína parecida a la de los potyvirus. Verver et al. (1998) lo propusieron como potencial vector de expresión de proteínas al comprobarse la correcta expresión de la GFP después de insertarla en el RNA-2 en reemplazo de la CP viral y, posteriormente, Gopinath et al. (2000) ensayaron distintas construcciones e hicieron cambios insertando sitios de procesamiento artificiales para mejorar la estabilidad genética de dicho inserto, alcanzando niveles de expresión de hasta $1 \%$ del total de proteínas solubles.

\section{CLONES INFECCIOSOS DE VIRUS}

Una de las restricciones para poder estudiar los virus, y modificarlos para su aplicación en áreas como la biotecnología, es contar con la herramienta de los clones infecciosos que permitan su manipulación a nivel molecular. Este hecho es de mayor importancia en lo referente a virus con genomas de RNA, como lo son una gran parte de los virus de vegetales, y la genética reversa aplicada a dicho grupo es la que ha permitido su manipulación y estudio casi al mismo tiempo que para otros tipos de virus. Por ejemplo, el avance de la tecnología de RNA y DNA y recombinante, y el desarrollo de las enzimas capaces de realizar la transcripción reversa, permitió la obtención de copias 
complementarias de DNA a partir de los genomas virales de RNA, así como su multiplicación en forma de plásmidos en células bacterianas (Lai, 2000).

La primera manipulación genética de un virus de RNA se realizó por medio de mutagénesis al bacteriófago Qß para estudiar su efecto en la replicación (Flavell et al., 1975). Estudios posteriores con dicho fago mostraron el potencial de usar la genética reversa como herramienta para el estudio de virus de RNA, ya que se logró obtener un clon infeccioso con el RNA del fago mutado (Domingo et al., 1976). Aún más, gracias al descubrimiento y comercialización de enzimas capaces de realizar el proceso de transcripción reversa, se pudo obtener un vector plasmídico con una copia en DNA del genoma completo del bacteriófago, de $4.5 \mathrm{~kb}$, que resultó ser infectivo y completar su ciclo cuando se insertaba en células de Escherichia coli (Taniguchi et al., 1978). Así comenzó a extenderse el uso de esta técnica a otro tipo de patógenos con genomas de RNA, muchos de los cuales se acumulan poco en sus plantas huésped o son difíciles de aislar. En 1981 Racaniello y Baltimore lograron sintetizar el cDNA del poliovirus tipo I (PV1) y clonarlo en el plásmido pBR322, para posteriormente secuenciar todos los 7410 nucleótidos de su genoma. De forma similar, la construcción de un clon completo de cDNA en un vector plasmídico del viroide del tubérculo fusiforme de la patata (Potato spindle tuber viroid, PSTVd), del que tanto el DNA como el RNA extraído de la bacteria fueron infecciosos al inocular plantas de tomate, amplió el potencial de investigar sobre la replicación y patogénesis de los viroides (Cress et al., 1983). Otra técnica de gran importancia, desarrollada por Ahlquist et al. en 1984, es la transcripción in vitro, con una RNA polimerasa de E. coli, en ese caso del cDNA del BMV con el fin de obtener RNA e infectar eficientemente plantas de cebada (Hordeum vulgare). Gracias a esta capacidad de obtener in vitro RNAs con las secuencias en sus extremos 5' y 3' lo más parecidas al virus silvestre y con los que infectar plantas, mediante la introducción en el cDNA de promotores para una determinada RNA polimerasa, se pudo mejorar el estudio de virus con genomas de RNA, inicialmente pequeños o segmentados como el virus del cascabeleo del tabaco (Tobacco rattle virus, TRV) (Hamilton y Baulcome, 1989) o el virus del moteado de las venas del tabaco (Tobacco vein mottling virus, TVMV) (Domier et al., 1989). Desde los primeros ejemplos hace más de dos décadas, y gracias al perfeccionamiento y multiplicación de las técnicas moleculares, se ha conseguido la clonación e inserción del cDNA en plásmidos bacterianos u otro tipo de vectores, así como la obtención de DNA (usando 
generalmente el promotor 35S del CaMV) o RNA (por medio de promotores de fagos como T3, T7 o SP6 y las correspondientes RNA polimerasas) infecciosos, de virus vegetales con genomas cada vez de mayor tamaño. Un logro sustancial en este campo fue la clonación del genoma de casi $30 \mathrm{~kb}$ del coronavirus de la gastroenteritis porcina (Transmissible gastroenteritis virus, TGEV), que forma parte del grupo de virus de RNA con los genomas más grandes que existen, insertándolo en un cromosoma bacteriano artificial de bajo número de copias (BAC), y con el que se pudieron recuperar partículas infecciosas (Almazán et al., 2000). Este hecho ha abierto la posibilidad de aplicar la genética reversa prácticamente a cualquier virus de vegetales, animales o humanos, cuyo genoma sea de RNA, y en la actualidad se siguen construyendo clones para distintos tipos de virus (Crutzen et al., 2009; Edwards y Weiland, 2010). No obstante, muchos de estos genomas pueden llegar a generar dificultades para la construcción de los clones infecciosos. En primer lugar, la síntesis de un cDNA a partir de RNA por el proceso de transcripción reversa es más difícil y con menos fidelidad de copia a medida que el RNA es más largo. La disponibilidad de polimerasas de alta fidelidad de copia para las técnicas de transcripción reversa $(R T)$ y $P C R$ ha permitido superar en gran medida este problema y se pueden obtener secuencias cada vez más parecidas a las consenso y con menos errores (Chen et al., 2009). Por otro lado, es posible que las secuencias virales sean tóxicas cuando se introducen en bacterias, lo cual puede llevar a su inestabilidad durante la propagación y la ocurrencia de mutaciones o deleciones parciales o totales del inserto viral. Este hecho puede ser mucho más frecuente en virus de RNA de sentido positivo, y puede explicarse en parte por la demostrada actividad de promotores eucarióticos en bacterias (Antonucci et al., 1989), o tal vez de promotores crípticos dentro de las secuencias virales o bacterianas, que promueven la expresión de genes cuyos productos son tóxicos. Recientemente, por ejemplo, Pu et al. (2011) han reportado una estrategia para minimizar la actividad de promotores crípticos que conllevan a la toxicidad de cDNAs de los flavavirus, causantes de distintas encefalitis.

De manera similar, frente a dicha inestabilidad y toxicidad de los cDNAs virales en bacterias se han empleado otros tipos de estrategias. Las más simples consisten en sustituir la cepa de E. coli donde se propaga el plásmido con el clon viral, el uso de plásmidos de bajo número de copias como BACs (Messerle et al., 1997; Hurrelbrink et al., 1999; Almazán et al., 2000), o incluso utilizar para la clonación otro tipo de vectores 
como los YACs, cromosomas artificiales de levaduras (Polo et al., 1997), u otros virus (Casais et al., 2001). En otros casos, existe la posibilidad de clonar el genoma viral en fragmentos de cDNAs separados que posteriormente se ligan y transcriben para obtener un RNA infeccioso (Kapoor et al., 1995; Yount et al., 2002), un método aplicado ampliamente a los Flavivirus (Gritsun y Gould, 1995), aunque este proceso puede ser mucho menos eficiente que cuando se parte de un clon completo. Adicionalmente, existe la alternativa de insertar intrones eucarióticos en la secuencia viral, para evitar la posible expresión de secuencias que resulten tóxicas, y los cuales son procesados in vivo una vez se han infectado las células huésped. Johansen (1996) empleó esta técnica exitosamente para estabilizar en E. coli el cDNA completo de dos ailsados del virus del mosaico del guisante transmitido por semilla (Pea seedborne mosaic virus, PSbMV). También se han insertado intrones para estabilizar en bacterias clones de otros virus como el causante de la sharka de los frutales de hueso (PPV) (López-Moya y García, 2000), el flavivirus de la encefalitis japonesa (Japanese encephalitis flavivirus, JE) (Yamshchikiv et al., 2001), y el TGEV (González et al., 2002). Este tipo de aproximaciones metodológicas tiene, sin embargo, el inconveniente de que los virus necesitan obligatoriamente una fase nuclear dentro de las células que infectan, para que ocurra el procesamiento de los intrones, y tener que alterar la secuencia del genoma viral de una forma que no siempre es deseada. Finalmente, en 2003 Satyanarayana et al. propusieron una alternativa de estabilización diferente, introduciendo mutaciones de cambio de pauta (inserciones o deleciones) en las regiones tóxicas del cDNA viral del virus de la tristeza de los cítricos (Citrus tristeza virus, CTV). En este caso es importante encontrar un punto intermedio en el que no se afecte la infectividad del clon y la toxicidad de la secuencia sea suficientemente baja para su propagación en vectores de alto número de copias en E. coli.

\section{SUPRESORES VIRALES DEL SILENCIAMIENTO INDUCIDO POR RNA}

Los organismos eucariotas, y en particular las plantas, dependen para su correcto funcionamiento de una serie de rutas reguladoras de genes que se denominan rutas de silenciamiento por RNA (Fig. 1.3). Un componente fundamental de dichas rutas son los pequeños RNAs (small RNAs o sRNAs), de 21 a 24 nucleótidos de tamaño, producidos de diversas maneras a partir de los RNAs de doble cadena (double stranded RNAs, dsRNAs) o de precursores parecidos a dsRNAs. Conjuntamente, el silenciamiento puede actuar tanto en la degradación específica de secuencia dirigida a RNAs 
invasivos, por medio de la cual se generan pequeños RNAs interferentes (siRNAs), como en la regulación de la expresión de genes endógenos, de la cual se obtienen los microRNAs (miRNAs) (Vaucheret et al., 2001). Dicho mecanismo también puede actuar en los procesos de metilación del DNA y la supresión de la transcripción, hecho que presumiblemente esté relacionado con la prevención del daño en el genoma que puedan causar elementos como los transposones (Baulcombe, 2004).

Estos pequeños RNAs ejercen su función mediante su incorporación a los complejos ribonucleoprotéicos del silenciamiento y gracias a la complementariedad de bases. De forma resumida, los dsRNAs de cualquier naturaleza son reconocidos y unidos por una proteína de unión a RNA de doble cadena (DRB) asociada a una de las proteínas similar a DICER (DICER-like, DCLs), las cuales tiene actividad RNasa de tipo III y los corta en fragmentos dobles de entre 21 a 24 nucleótidos con grupos fosfato en 5' característicos y dos nucleótidos sobresalientes en 3'. Estos dupletes se separan y una de las cadenas se une a una de las proteínas Argonauta (AGOs), que componen el complejo de silenciamiento inducido por RNA (RISC), por medio del cual la fuente original de los dsRNAs, ya sea DNA o RNA, es reconocida por su homología de secuencia y su expresión es inhibida. Además, en plantas la señal del silenciamiento puede expandirse sistémicamente desde su punto de origen gracias a la acción de las RNA polimerasas RNA dependientes (RdRPs) que la amplifica (Voinnet, 2008).

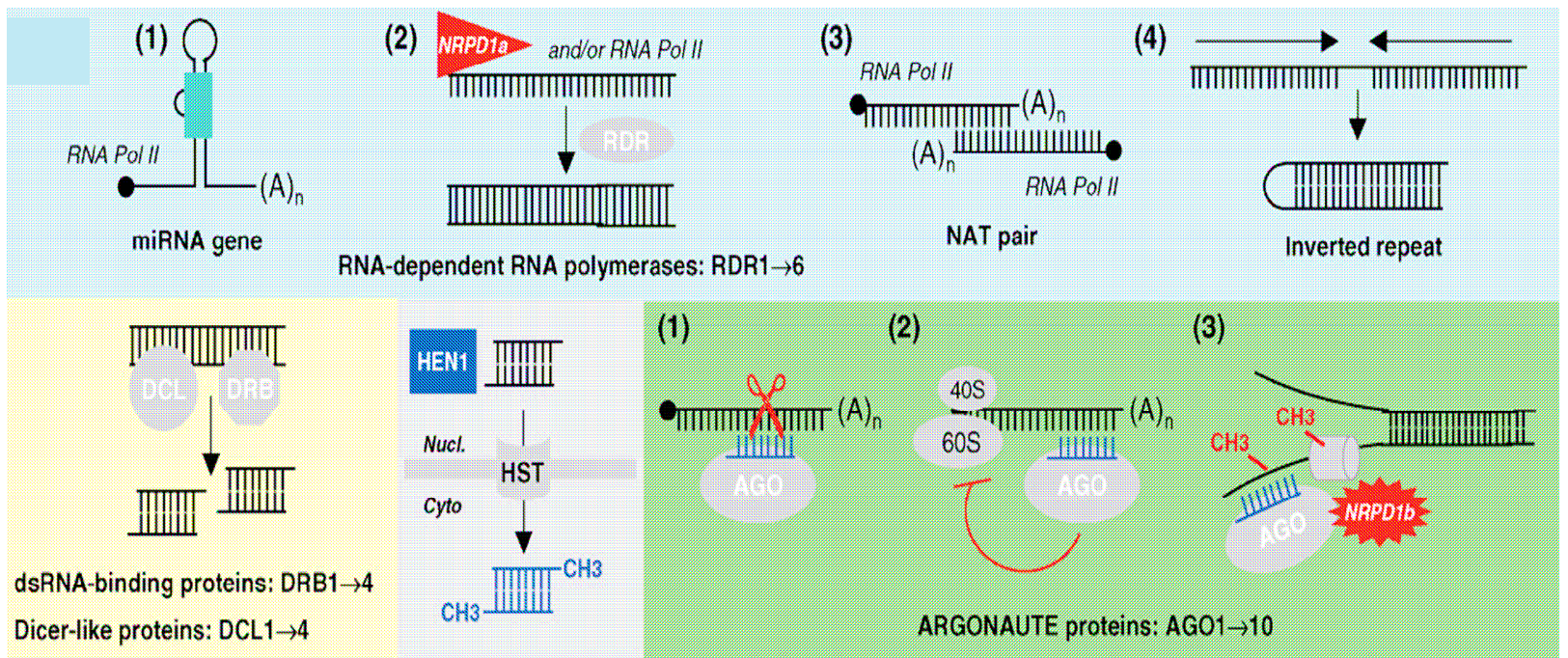

Figura 1.3. Esquema general del proceso de silenciamiento caracterizado en Arabidopsis. Panel superior: 4 diferentes fuentes de RNAs bicatenarios. Panel inferior: a la izquierda la unión y corte del RNA bicatenario en pequeños RNAs por las proteínas DRB y DCL. En el centro su metilación por la proteína HEN1 y su transporte al citoplasma. A la derecha, la acción del complejo RISC por medio de la interacción de las proteínas AGO y los sRNAs que puede llevar a (1) el corte del RNA mensajero original, (2) la represión de la traducción o (3) la metilación de la citosina o las histonas en el DNA. Tomado de Voinnet et al., 2008. 
Uno de los papeles más relevantes atribuidos a la maquinaria de silenciamiento de RNA en plantas es como parte de los procesos de defensa contra patógenos y, concretamente, contra virus. Durante la infección los virus pueden generar dsRNAs que son reconocidos por la planta y que activan la maquinaria de silenciamiento para impedir su acumulación, un proceso conocido como silenciamiento inducido por virus (virus induced gene silencing, VIGS) (Ruiz et al., 1998; Xie y Guo, 2006). Se ha visto que dichos dsRNAs pueden originarse, además de como intermediarios del proceso de replicación, por el plegamiento intramolecular de los RNAs virales que lleva a la formación de horquillas imperfectas, las cuales se asemejan a algunos precursores de microRNAs. Adicionalmente, dentro de las células vegetales, los virus también pueden interferir en las rutas de silenciamiento endógenas para regular la expresión de genes específicos, por ejemplo, para impedir la acción de los mecanismos de defensa de la planta (Dunoyer y Voinnet, 2005).

Los virus de vegetales han desarrollado mecanismos para contrarrestar los procesos de silenciamiento y defensa de las plantas por medio de las proteínas denominadas supresores del silenciamiento, conocidas primeramente como determinantes de patogenicidad, y descritas hace más de una década como la respuesta de los virus a los mecanismos de defensa vegetales (Voinnet et al., 1999). Los supresores no solamente son proteínas que prácticamente todos los virus vegetales han desarrollado, sino que ahora se sabe que virus animales y humanos también los poseen (Li y Ding, 2006). En virus de plantas los supresores son numerosos y variados, multifuncionales, pueden intervenir en uno o múltiples pasos durante el transcurso del silenciamiento génico, y muy frecuentemente poseen sitios de unión a RNA u otras moléculas específicas. Todo ello para permitir que se desarrolle la infección, pueda ocurrir la replicación y acumulación del virus, y se dé el movimiento sistémico a lo largo de toda la planta (Wang y Metzlaff, 2005).

En cuanto al tipo de intervención en la ruta del silenciamiento, existen algunos supresores que afectan el procesamiento del RNA de doble cadena (dsRNA), interfiriendo en la función de las proteínas DRBs o de las proteínas DCLs encargadas de su corte en pequeños RNAs. Este es el caso de la proteína p38 del virus del arrugado del nabo (Turnip crinkle virus, TCV) (Qu et al., 2003), la $2 b$ del virus del mosaico del pepino (Cucumber mosaic virus, CMV) (Diaz-Pendon et al., 2007), y la P6 
del CaMV (Haas et al., 2008). Otros tienen dominios de unión a RNA, mediante los cuales pueden retener los siRNAs e impedir que interaccionen con el complejo RISC para desencadenar el silenciamiento. Este es el caso de la proteína HC-Pro de los potyvirus, la cual parece interferir en variados puntos de la ruta, y que posee un motivo conservado (FRNK) por medio del cual puede unir siRNAs y miRNAs de doble cadena y está relacionado con el desarrollo de síntomas (Shiboleth et al., 2007). También forman parte de este grupo las proteínas p21 del virus del amarillamiento de la remolacha (Beet yellows virus, BYV) y la proteína p19 del PVX, para las cuales Lakatos et al. (2006) comprobaron con ensayos in vitro e in vivo que ejercen su acción mediante la unión a pequeños RNAs. Asimismo, la proteína NS3 del virus de la hoja blanca del arroz (Rice hoja blanca virus, RHBV) ha mostrado gran afinidad por los sRNAs de $21 \mathrm{nt}$ de longitud (Hemmes et al. 2007). Existen también supresores que interfieren en la estabilización de los pequeños RNAs, la cual se lleva a cabo a través del proceso de metilación por parte de la metiltransferasa HEN1. En este caso aunque no se conoce con exactitud el mecanismo de acción se sabe que pueden bloquear dicha estabilización proteínas como p21, p19, HC-Pro (Yu et al., 2006) y la proteína 126K del TMV, que podría realizar la demetilación o unir sRNAs para impedir la acción de HEN1 (Vogler et al., 2007). Por otro lado, algunas proteínas supresoras pueden interactuar directamente con componentes del complejo de silenciamiento RISC para disminuir así su disponibilidad y por consiguiente la eficiencia del silenciamiento. Dentro de este grupo se pueden incluir la proteína P0 del virus del amarillamiento occidental de la remolacha (Beet western yellow virus, BWYV), que interacciona con la proteína AGO1 (Bortolamiol et al., 2007), y la proteína 2b del CMV, que como se ha mencionado antes puede interactuar con las proteínas DCL y también con AGO1 (Zhang et al., 2006). Otros supresores son capaces de bloquear la amplificación y movimiento de la señal de silenciamiento dentro de la planta, permitiendo la invasión por parte del virus, como por ejemplo la proteína V2 del virus del rizado amarillo del tomate (Tomato yellow leaf curl virus, TYLCV), para la que Glick et al. (2008) describieron la capacidad de unirse a la proteína SGS3 vegetal relacionada con dicho proceso. Finalmente, existen supresores del silenciamiento virales para los cuales no se ha definido un mecanismo de acción específico, ya que no se han identificado dominios funcionales relacionados con el mecanismo de supresión ni alguna relación con su localización subcelular, aunque se cree que su secuencia y estructura pueden ser de gran importancia y su actividad supresora ha sido comprobada. Este es el caso de proteínas tan variadas como la 
TGBp1 del PVX (Senshu et al., 2009), la proteína 16K del TRV (Ghazala et al., 2008), la proteína yb del virus del mosaico estriado de la cebada (Barley stripe mosaic virus, BSMV) (Bragg y Jackson, 2004) o la proteína P15 de los peclovirus (Dunoyer et al., 2002).

Las proteínas supresoras del silenciamiento codificadas por los virus de vegetales, además de ser objeto de estudio para la descripción a nivel molecular de los factores relacionados con las interacciones virus-plantas y del proceso de silenciamiento génico, son una potencial herramienta para la mejora de la eficiencia en los sistemas de expresión de proteínas recombinantes en plantas. En este sentido, además del uso de plantas transgénicas o de vectores virales de expresión, es común llevar a cabo ensayos de expresión transitoria por medio de $A$. tumefaciens para probar la posible expresión y eficiencia de algunas proteínas o intentar coexpresar más de una proteína en una misma región de tejido vegetal (Fischer et al., 1999). Aunque este sistema de agroinfiltración es susceptible de usarse para la producción de proteínas a gran escala, con frecuencia la expresión alcanza un nivel máximo en hasta 3 días y disminuye después radicalmente. Este hecho se atribuyó en principio a causas como una ineficiente inserción del T-DNA, la muerte celular o una combinación errónea del sistema vegetal y la cepa de $A$. tumefaciens. Sin embargo, ahora se sabe que gran parte de la transitoriedad de la expresión es debida a la acción del silenciamiento genético postranscripcional (PTGS) en las plantas (Johansen y Carrington, 2001). Por este motivo, se ha estudiado el efecto que puede tener en los niveles de expresión de una determinada proteína la adición, conjunta o por separado, de una proteína supresora viral. Por ejemplo, Voinnet et al. (2003) ensayaron el efecto que distintos supresores del silenciamiento podían tener en el proceso de PTGS, iniciado al agroinocular plantas de $N$. benthamiana con vectores que contienen la proteína reportera GFP. En resultados previos con plantas transgénicas que expresan constitutivamente la GFP, se había visto que la co-inoculación de la GFP con el supresor p25 del PVX evitaba que ocurriera dicho silenciamiento. Posteriormente, encontraron que algunos supresores mejoran la expresión de la GFP, y hacen que esta ocurra durante más tiempo, en ensayos de expresión transitoria. El supresor p19 del TBSV mostró ser el más efectivo, ya que a 5 días después de la inoculación los niveles de GFP se incrementaron desde 5-12 $\mu$ g por gramo de tejido fresco (cuando no está el supresor) hasta $270-340 \mu \mathrm{g}$ por gramo de tejido. Además, la proteína HC-Pro del PVY 
también mostró ser buen inhibidor del silenciamiento de la GFP, aunque no es comparable con p19 que permite la expresión de la GFP hasta 20 dpi. La utilidad del supresor HC-Pro también se puede apreciar en el estudio realizado por Chiera et al., en 2008, en el cual utilizando un ensayo de expresión transitoria basado en el bombardeo de partículas de cotiledones de alubias Lima, se vio que la expresión de la GFP puede alcanzar niveles máximos a las 49 horas postintroducción, en comparación con $21 \mathrm{~h}$ cuando no se introduce el supresor, cuando se introduce por separado, y hasta mas de 50 h cuando HC-Pro está fusionada a la GFP. De forma similar, utilizando este mismo tipo de ensayos de expresión transitoria, Dhillon et al. (2009) evaluaron el efecto en la expresión de la GFP de los supresores del silenciamiento HC-Pro (potyvirus), p19 (tombusvirus), p21 (closterovirus), $\gamma \beta$ (hordeivirus), AL2 (begomovirus) y 126K (tobamovirus), como fusiones traduccionales en 3' o en cointroducciones. En sus resultados las co-introducciones fueron más eficientes, y los supresores HC-Pro, p19 y $\gamma \beta$ permitieron obtener mayores niveles de expresión y durante más tiempo de la proteína GFP, mientras que AL2, p21 o 126K provocaron o bien una reducción en la expresión, o ningún cambio con respecto al control sin ningún supresor.

En conjunto, este y otros estudios han mostrado que es posible emplear proteínas del silenciamiento de diferentes virus para aumentar y estabilizar la expresión de proteínas reporteras en plantas, indicando su gran potencial para mejorar también la expresión de proteínas recombinantes de interés en sistemas vegetales. Sin embargo, se debe tener en cuenta que cada tipo de estudio y cada combinación supresor-planta puede representar un proceso individual, y los resultados en cada caso pueden variar ampliamente.

\section{PROTEÍNAS FLUORESCENTES}

El rápido desarrollo de técnicas basadas en proteínas fluorescentes (FPs), hasta llegar a establecerse en la actualidad como una herramienta fundamental en distintos y variados campos de la investigación científica, como la biotecnología y la medicina, tuvo su inicio en 1962 con la primera descripción, caracterización y purificación de la proteína fluorescente verde (GFP) de la medusa Aequorea victoria. Dicha proteína es un componente del proceso de bioluminiscencia, y es capaz de absorber la luz azul emitida por la aequorina de la medusa y transformarla en luz verde (Shimomura et al., 1962). Esta GFP tiene características interesantes como mantener su fluorescencia al 
incubarse con agentes químicos como ácido clorhídrico $(\mathrm{HCl})$, urea o sodio dodecil sulfato (SDS), y ser estable en un rango de $\mathrm{pH}$ desde 5.5 hasta 12 o a temperaturas altas (Bokman y Ward., 1981). Aproximadamente 30 años después, conociendo sus características de excitación y emisión de energía, la descripción de su cromóforo y factores que pueden afectar su estabilidad como el pH o la temperatura, y después de realizarse la clonación del gen de la GFP, Chalfie et al. (1994) la expresaron tanto en la bacteria E. coli como en el nematodo Caenorhabditis elegans. Lo que observaron fue una adecuada fluorescencia gracias a la correcta formación del cromóforo sin la necesidad de ninguna enzima o cofactor adicional, y propusieron su uso potencial para monitorizar la expresión de genes y la localización de proteínas en organismos vivos ya que se puede fusionar a otras proteínas sin perder su fluorescencia, no es tóxica, y permite análisis no destructivos.

Posteriormente, se generaron proteínas variantes por medio de mutaciones en la secuencia original del cromóforo de la GFP, llegando a dividirse en 7 clases distintas, y las cuales tienen diferentes espectros de excitación y emisión que abarcan longitudes de onda desde aproximadamente 440 nanometros (nm) (BFP), el color azul del espectro visible, hasta casi $530 \mathrm{~nm}$ (YFP), el color amarillo (Tsien, 1998). Por otro lado, se han descubierto y clonado un gran número de proteínas fluorescentes y cromoproteínas no fluorescentes (capaces de absorber pero no emitir luz) de otros animales (Fig. 1.4), como miembros de las clases de celenterados Anthozoa e Hydrozoa y los géneros Aequorea, Obelia, Phialidium o Renilla. Dichas proteínas comparten hasta un $30 \%$ de identidad de secuencia con la GFP, se pueden dividir, dependiendo de los colores de emisión, en nuevas proteínas verdes (similares a GFP), proteínas amarillas (YFP) y proteínas naranja-rojas (RFP), y han aumentando considerablemente el potencial de emplearlas en diferentes tipos de estudios como marcadores fluorescentes (Matz et al., 2002).

En cuanto a las proteínas fluorescentes azules, la EBFP fue una de las primeras en desarrollarse a partir de la GFP de A. victoria, pero presentaba una baja fluorescencia y poca fotoestabilidad. Por este motivo, se han desarrollado nuevas variantes con características mejoradas para abrir la posibilidad de realizar estudios de imagen en células vivas, y que pueden observarse con filtros estándar para análisis de fluorescencias en el espectro de luz azul, como las denominadas SBFP2 (Kremers et 
al., 2007) y EBFP2 (Mena et al., 2006), siendo esta última la más fluorescente y estable. En cuanto a las proteínas de color cian, de $470 \mathrm{~nm}$ a $500 \mathrm{~nm}$ dentro del espectro de luz visible, las primeras fueron simples variantes de la ECFP (una modificación de la GFP) hasta la obtención de la mTFP1, una variante monomérica de una proteína extraída de una especie de Clavularia con mayor estabilidad en medios ácidos y una fluorescencia más alta (Ai et al., 2006). A pesar de la existencia de esta proteína, también se han intentado mejorar las proteínas derivadas de la ECFP para aumentar su brillo, solubilidad y eficiencia en estudios de interacción de proteínas como de transferencia de energía (FRET, fluorescene resonance energy transfer), generando nuevas proteínas como SCFP y SYFP (Kremers et al., 2006).

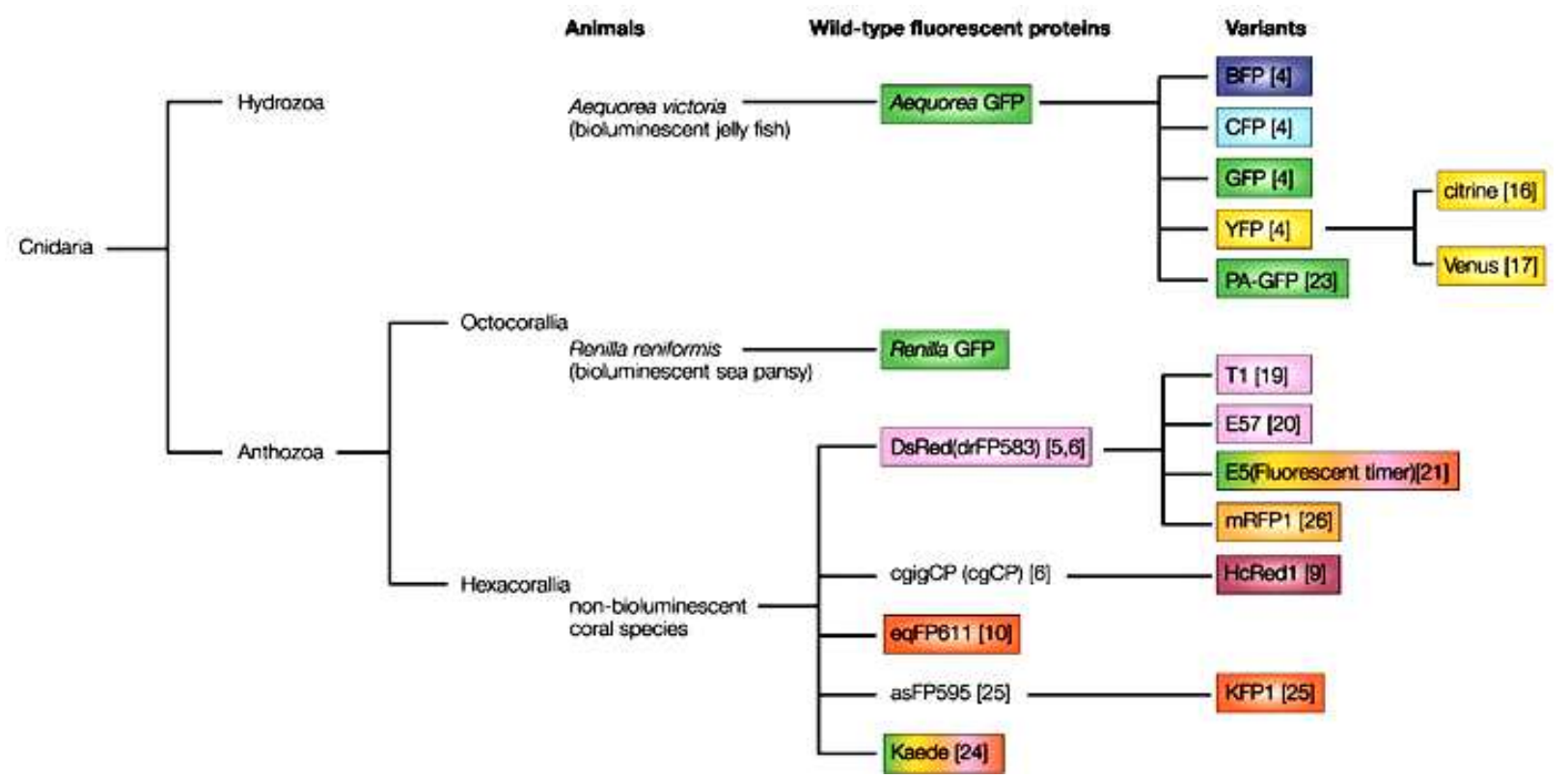

Figura 1.4. Filogenia de algunas proteínas fluorescentes y su procedencia. Los colores indican la longitud de onda máxima de emisión. BFP: proteína fluorescente azul (blue fluorescent protein). CFP: proteína fluorescente cian (cyan fluorescent protein). GFP: proteína fluorescente verde (green fluorescent protein). KFP1: proteína fluorescente kindling (kindling fluorescent protein). mRFP1: proteína fluorescente roja monomérica (monomeric red fluorescent protein). PA-GFP: proteína fluorescente verde fotoactivable (photoactivatable-GFP). YFP: proteína fluorescente amarilla (yellow fluorescent protein). Tomado de Miyawaki et al., 2003.

En el siguiente rango del espectro se encuentran las proteínas verdes, con emisiones de entre $500 \mathrm{~nm}$ y $525 \mathrm{~nm}$ aproximadamente. A este grupo pertenecen proteínas provenientes de fuentes variadas que incluyen diferentes especies de Aequorea, copépodos, anfioxos y arrecifes de coral (Li et al., 2009). A pesar de su gran diversidad, la mayoría de estas proteínas no ofrecen características mejoradas de fluorescencia ni estabilidad molecular frente a la EGFP, la proteína derivada de la GFP original de $A$. victoria por medio de mutaciones y que continúa siendo ampliamente usada. Una excepción es la proteína esmeralda, derivada de la GFP, que tiene además de las 
ventajas y mutaciones de la EGFP otras nuevas mutaciones que mejoran su ensamblaje y luminosidad, haciéndola llamativa para estudios de imagen de células vivas (Cubitt et al., 1999). La única característica negativa de dicha proteína es la ocurrencia en ciertos ambientes de un rápido photobleaching, la destrucción fotoquímica del fluoróforo. Otra proteína desarrollada con mejores características que la EGFP y esmeralda, es la llamada "superfolder" GFP la cual, además de ser levemente más brillante, estable en ambientes ácidos y resistente a elementos químicos, tiene una mejor capacidad de plegarse correctamente cuando está fusionada a otras proteínas. Dicha estabilidad estructural es de gran interés cuando se realizan estudios de proteómica, como por ejemplo ensayos de localización o interacciones proteínaproteína (Pédelacq et al., 2006).

Cerca del espectro del verde, se encuentran las proteínas fluorescentes amarillas (YFPs). Aunque la primera variante derivada de la GFP, EYFP, continúa empleándose en algunos estudios, esta tiene algunas desventajas que se han intentado superar con modificaciones genéticas. Un ejemplo es la proteína Citrina, descrita en un ensayo de expresión en E. coli (Griesbeck et al., 2001), y que presenta 5 mutaciones de la GFP que hacen que presente una fluorescencia amarilla alta, se pliegue correctamente a 37 @C y sea más resistente a medios ácidos. De forma similar, se desarrolló la proteína mVenus, creada introduciendo 5 mutaciones más en EYFP y que ha mostrado, además de una mejor fluorescencia, una estabilidad mejorada en cuanto a temperatura y acidez del medio donde se encuentra, así como un proceso de maduración más rápido (Rekas et al., 2002). Otro ejemplo es la proteína Ypet, una proteína amarilla generada a partir de otra YFP, con el objetivo específico de mejorar la sensibilidad de un sistema azulamarillo de transferencia de energía (FRET) para estudios de interacción o análisis celulares a nivel molecular (Nguyen y Daugherty, 2005).

En último lugar se encuentran las proteínas fluorescentes que emiten en un rango aproximado de longitud de onda entre $560 \mathrm{~nm}$ y $650 \mathrm{~nm}$, en colores naranjas y rojos, casi todas obtenidas a partir de diversas especies de coral. Denominadas como RFPs, muchas de estas proteínas en realidad tienen espectros correspondientes a colores naranja, como es el caso de DsRed, TagRFP y tdTomato (Shaner et al., 2007). En general tienen buenas características en cuanto a luminiscencia y estabilidad, y debido a que durante mucho tiempo no existieron proteínas que emitieran en esa parte del 
espectro de luz visible, han emergido como una herramienta con un alto potencial para su empleo en técnicas de visualización molecular y celular. Un ejemplo es la proteína Kusabira-Orange, obtenida de Fungia concinna, y modificada genéticamente para mejorar su estabilidad en distintos pHs y fotoestabilidad (Karasawa et al., 2004), y a partir de la cual se generó la proteína monomérica mKO con la adición de 20 mutaciones. Asimismo, la proteína tetramérica DsRed ha dado origen a diferentes proteínas en el camino de desarrollar una versión monomérica. Una de ellas es la tdTomato, tal vez una de las más brillantes y fotoestables de todas las proteínas fluorescentes que existe, diseñada para permitir fusiones a otras proteínas sin afectar sus características (Campbell et al., 2002). En cuanto a las proteínas rojas, estas son interesantes por su aplicabilidad en estudios de imágenes multicolor y porque a mayor longitudes de onda hay una menor fototoxicidad y se pueden realizar análisis más profundos dentro de tejidos biológicos. Las que se han desarrollado por medio de estudios mutacionales de la proteína mRFP1 se han nombrado como frutas por su similitud en el color de emisión y las más conocidas y utilizadas son mStrawberry y mCherry (Patterson, 2004). Con una capacidad de fluorescencia parecida a esta última, y después de realizar determinadas mutaciones alrededor del cromóforo de la TagRFP, se ha logrado desarrollar la proteína mKate (similar a una proteína llamada Katushka) la cual ha ampliado el espectro de emisión hasta el rojo lejano, con longitudes de onda alrededor de $650 \mathrm{~nm}$ (Shcherbo et al., 2007).

El descubrimiento y desarrollo de las proteínas fluorescentes, desde la GFP hasta todas sus diversas variantes (Fig. 1.5), ha permitido el estudio de una sinnúmero de procesos, organismos y moléculas, creando la posibilidad de fusionarlas prácticamente a cualquier producto genético, direccionarlas a compartimentos subcelulares o tejidos específicos, etc., y así observar su expresión en células, tejidos u organismos completos para su descripción. En primer lugar está su aplicación como marcadores moleculares para el estudio de la activación y el proceso de expresión de genes, el etiquetado multicolor de proteínas, el análisis del desarrollo y crecimiento celulares o la descripción de células cancerígenas o microorganismos patogénicos y virus, que se pueden emplear en bacterias, hongos, insectos, plantas y animales (Stepanenko et al., 2008). De este modo, el uso de estas proteínas en estudios sobre ciclos celulares permite conocer la localización a nivel subcelular de factores reguladores y estructuras microscópicas, así como la descripción de su dinámica en el tiempo gracias a técnicas 
de visualización en tiempo real (un ejemplo es el estudio de Bonnet et al., en 2008). Las proteínas fluorescentes también actúan como biosensores y permiten estudiar la dinámica de determinadas proteínas dentro de las células, mediante fusiones a las mismas, y mediante técnicas como la recuperación de la fluorescencia después del photobleaching (fluorescent recovery after photobleaching, FRAP) o la pérdida de fluorescencia durante el photobleaching (fluorescence loss in photobleaching, FLIP) (Bancaud et al., 2010). Otra metodología ampliamente usada para el estudio de las interacciones moleculares entre proteínas, basada en el uso de 2 o más proteínas fluorescentes fusionadas a cada proteína de interés, es la denominada FRET o de transferencia de energía. Esta se basa en la capacidad de transferir energía desde un fluoróforo hasta otro si se encuentran lo suficientemente cerca, de modo que la emisión de fluorescencia de un donador permite la excitación, y posterior emisión, del aceptor (Gambin y Deniz, 2010).

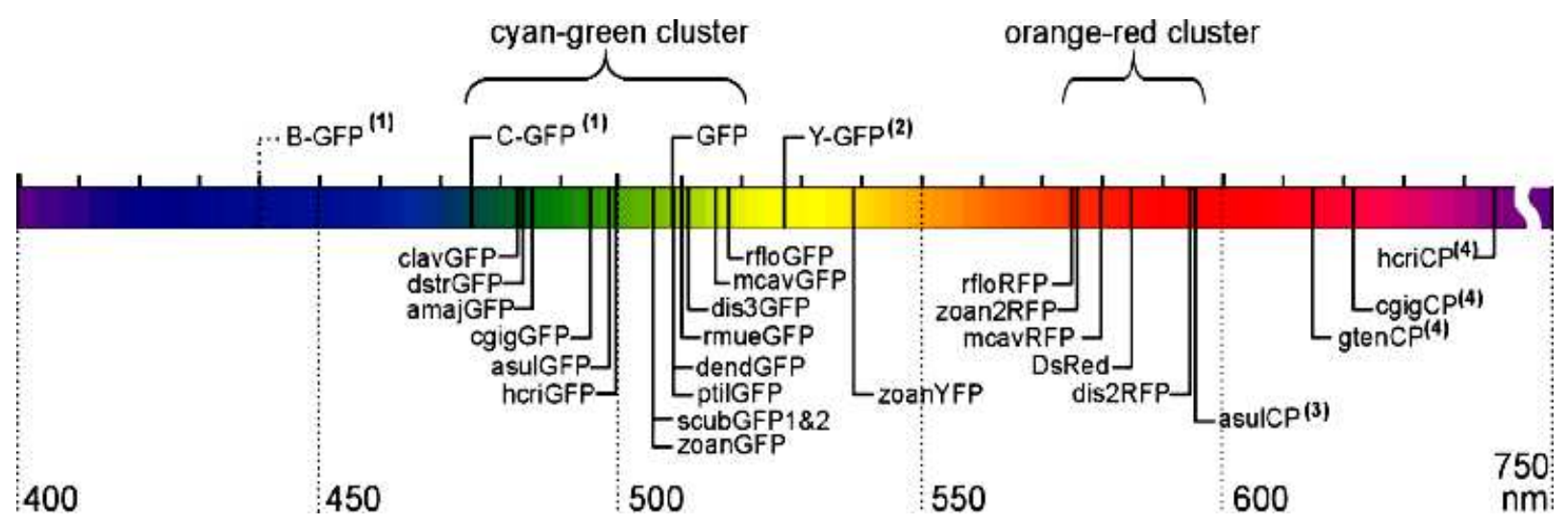

Figura 1.5. Longitudes de onda de emisión máximas de algunas de las proteínas fluorescentes de tipo GFP y sus variantes obtenidas por mutación. Tomado de Matz et al., 2002.

Con respecto a las aplicaciones de la GFP y otras proteínas fluorescentes en plantas, en Leffel et al. (1997) se describen y enumeran algunas de las más importantes. Tal vez la primera ventaja que ofrecieron dichas proteínas fue ser una alternativa superior en ensayos de expresión transitoria y estable de proteínas al hasta entonces empleado gen repostero GUS ( $\beta$-glucuronidasa), o a marcadores de selección como resistencia a antibióticos, que pueden ser invasivos o destructivos en los tejidos de las plantas. Por otro lado, y adicionalmente a las aplicaciones como marcador genético en estudios de desarrollo, localización subcelular o tráfico de membranas en células vegetales, las FPs han sido ampliamente utilizadas en el estudio de enfermedades causadas por distintos patógenos en plantas, particularmente virus. Por medio de ellas, fusionándolas a las CPs virales, se puede describir con detalle a nivel de células, órganos y plantas enteras 
como ocurre el movimiento de las partículas virales (Cohen et al., 2000). Asimismo, su uso permite el estudio de la localización de los ácidos nucleicos virales, por ejemplo en protoplastos, para monitorear procesos relacionados con la infección como la replicación y la traducción (Zhang y Simon, 2003) o ensayos de interacción proteínaproteína y ácidos nucleicos-proteína entre el virus y el huésped (Huang et al., 2001). En general, las FPs se han usado en todo tipo de estudios básicos sobre las infecciones virales $y$, además, su eficiente papel como genes marcadores o reporteros también ha beneficiado ampliamente el desarrollo de herramientas biotecnológicas como diversos vectores virales para la expresión de genes heterólogos en plantas o para el análisis del proceso de silenciamiento genético y VIGS (Lim et al., 2010).

\section{LAS ANTOCIANINAS}

Las plantas son capaces de responder a un ambiente que está en constante cambio gracias a su flexible metabolismo y a la producción de una gran variedad de metabolitos secundarios. Existen rutas biosintéticas básicas conservadas, en una amplia gama de especies, a partir de las cuales se producen modificaciones que permiten la generación de un gran número de estos compuestos. Un extenso grupo dentro de los metabolitos secundarios es el de los flavonoides, una familia de compuestos polifenólicos de bajo peso molecular producidos por diferentes tipos de plantas. Como parte de las variadas funciones que pueden tener dentro de las plantas los flavonoides proporcionan la pigmentación a las flores, los frutos y las semillas, para atraer a polinizadores y dispersores de semillas, están implicados en los mecanismos de defensa y señalización frente a patógenos y están relacionados con la fertilidad y la germinación del polen (Koes et al., 1994). Se conocen más de 6000 flavonoides y todos comparten la misma estructura bioquímica básica, es decir, un núcleo compuesto por dos anillos de 6 átomos de carbono ( $A$ y $B$ ) interconectados por un anillo $C$ variable. $D e$ acuerdo a las modificaciones en este último anillo los flavonoides pueden dividirse en flavanones, isoflavones, flavones, flavonoles, flavanoles y antocianinas (Schijlen et al., 2004). Estas últimas son pigmentos solubles en agua, responsables de dar colores azul, púrpura, violeta y rojos a distintos tejidos. Se sintetizan en el citoplasma de las células pero se acumulan en las vacuolas de forma glicosilada y se pueden expresar permanente $o$ transitoriamente en las plantas, y en respuesta a factores como el fotoperíodo (fotoinducción), la temperatura u otro tipo de señales ambientales. Son abundantes en tejidos como frutos y flores, aunque también pueden acumularse en 
raíces y hojas, y cumplen algunas funciones adicionales a las anteriormente descritas, como proteger a las plantas de la luz ultravioleta, participar en la resistencia al frío, la sequía y factores bióticos como hongos y bacterias, y tener capacidad antioxidativa por absorción de los radicales de oxígeno, lo cual las hace atractivas a nivel de salud humana para ayudar a prevenir enfermedades como el cáncer (Chalker-Scott, 1999).

En general, la ruta biosintética de las antocianinas está bien caracterizada (detallada en Holton y Cornish, 1995) y una gran mayoría de los estudios para su descripción, y el aislamiento de los genes que la componen, se han realizado basándose en plantas de maíz (Zea mays), de boca de dragón (Antirrhinum majus), y de petunia (Petunia hybrida) (Fig. 1.6). El proceso biosintético (también para otros flavonoides) se basa en los precursores malonil-CoA (del metabolismo de los carbohidratos) y p-cumaril-CoA (de la ruta de los fenilpropanoides), los cuales son procesados por la enzima chalcona sintasa (CHS) para iniciar el proceso. Esta ruta es larga, compleja y contiene múltiples componentes que pueden dividirse en genes estructurales y genes reguladores, siendo estos segundos los que modulan la expresión de los primeros. Algunos ejemplos de los genes estructurales principales son los que corresponden a las enzimas CHS, chalcona isomerasa $(\mathrm{CHI})$, la flavonona y flavonoide hidroxilasas (F3H y $\mathrm{F} 3$ 'H), dihidroflavonol reductasa (DFR), antocianidina sintasa (ANS) y antocianina glucosiltransferasa (3GT), siendo esta última la encargada de estabilizar la molécula añadiendo un azúcar para hacerla soluble y permitir su acumulación en las vacuolas de las células.

En cuanto a los genes reguladores, también estos son numerosos y variados, y son los encargados de coordinar el nivel de expresión de determinados genes estructurales, modulando así la biosíntesis y la cantidad de antocianinas presentes en un determinado órgano o tejido vegetal. Estos factores de transcripción están muy conservados en distintas especies vegetales y pueden dividirse en las dos familias cMYB y c-MYC, definidas por sus homologías de secuencia con dos distintos protooncogenes de vertebrados. Se han identificado un gran número, así como también caracterizado rutas de activación o inhibición de expresión de determinadas enzimas dentro de la ruta de las antocianinas, tanto en las tres plantas modelo indicadas como en muchas otras (Schijlen et al., 2004). La identificación de estos genes se ha realizado mediante la caracterización de diversos mutantes en los que se ha reducido o bloqueado por completo la síntesis de antocianinas y se ha visto que son similares en 
distintas especies vegetales, sugiriendo un origen evolutivo común. En maíz se han descrito los grupos $\mathrm{C} 1$ y $\mathrm{R}$ de genes cuyos miembros pueden regular uno o más componentes de la ruta para modularla por completo (Grotewold et al., 1998). En petunia los factores de transcripción que afectan la ruta de las antocianinas se han nombrado de acuerdo a los mutantes en los que se han descrito, siendo algunos de los más estudiados $A n 1, A n 2, A n 4$ y $A n 11$, y se ha visto que pueden ser redundantes, afectando cada uno a numerosas enzimas (Quattrocchio et al., 1993). Finalmente, en las flores de $A$. majus, se han definido varios genes reguladores, siendo tres de los más conocidos Delila (Del), Eluta y Rosea1. La expresión de la CHS y la CHI muestra poca regulación mientras que los pasos subsiguientes de la ruta necesitan la acción de Del y están sujetos a una regulación cuantitativa de los demás genes reguladores (Holton y Cornish, 1995). Además, estudios posteriores han mostrado las posibles relaciones que pueden existir entre distintos genes reguladores, como por ejemplo la interacción que se da entre Del y Rosea1 para promover una mayor expresión de ciertos genes de la ruta y, al final, una mayor acumulación de antocianinas (Schwinn et al., 2006).

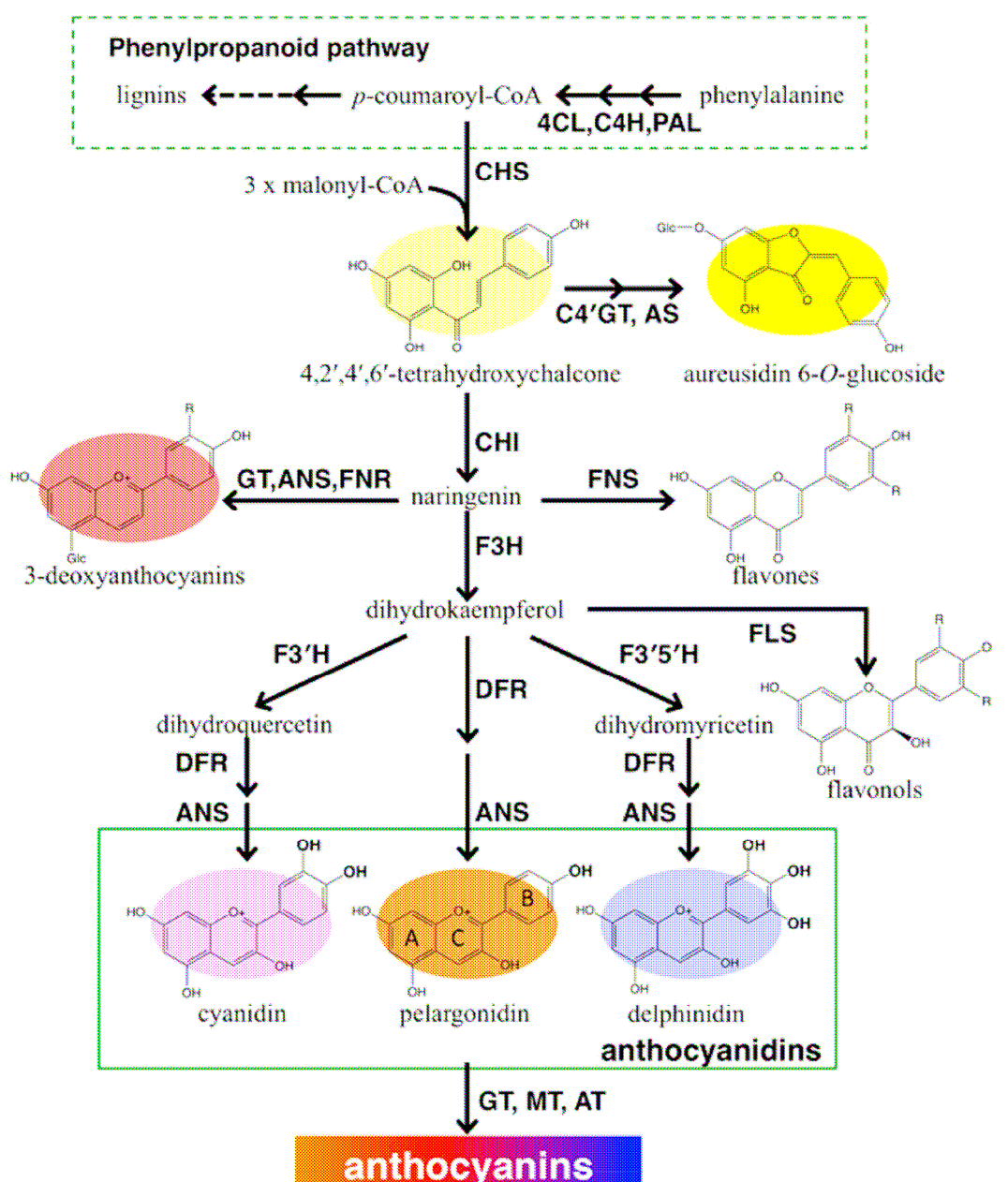

Figura 1.6. Esquema general de la ruta de biosíntesis de las antocianinas en plantas. En cada paso se indican sobre la flecha las enzimas involucradas en la reacción. Tomado de Nishihara y Nakatsuka, 2011. 
CAPÍTULO 2:

OBJETIVOS 
- Construir tres nuevos plásmidos con el mismo clon infeccioso del virus del grabado del tabaco (TEV) que permitan infectar plantas con RNA, DNA y por agroinoculación, y que sean más estables durante su propagación en Escherichia coli que el plásmido ancestral pTEV7DA.

- Desarrollar un vector viral desarmado basado en un clon infeccioso del TEV para la expresión equimolar y simultánea de múltiples proteínas en plantas, y evaluar su utilidad expresando tres proteínas reporteras fluorescentes o dos factores de transcripción de Antirrhinum majus involucrados en la biosíntesis de antocianinas.

- Estudiar el efecto sobre la proteína reportera mCherry de la coexpresión de diferentes supresores virales del silenciamiento en el vector viral basado en el TEV.

- Continuar la deconstrucción del vector, identificando nuevos cistrones virales que se puedan suministrar en trans.

- Evaluar la aplicación del factor de transcripción Rosea1 de A. majus como marcador reportero visual para seguir la infección y movimiento de virus en plantas. 
CAPÍTULO 3. RESULTADOS:

CONSTRUCCIÓN DE CLONES INFECCIOSOS

Y ESTABLES DEL VIRUS DEL GRABADO DEL TABACO (TEV) 
Virus Research 149: 234-240 (2010)

\section{Stability of Tobacco etch virus infectious clones in plasmid vectors}

\section{Leonor C. Bedoya, José-Antonio Darós}

Instituto de Biología Molecular y Celular de Plantas (CSIC-Universidad Politécnica de Valencia), Avenida de los Naranjos,46022 Valencia, Spain

\section{ABSTRACT}

Tobacco etch virus (TEV) has been traditionally used as a model to research many aspects of the molecular biology of plant RNA virus and, more recently, experimental evolution. However, the only plasmid of this virus species with an infectious clone that has been commonly available to research (pTEV7DA) is rather unstable when propagated in the bacterium Escherichia coli. Here, the TEV infectious clone contained in PTEV7DA is used to construct three new plasmids that allowed infecting the host plants from RNA transcripts synthesized in vitro (pMTEV), directly from plasmid DNA (p35TEV) and by agroinoculation (pGTEV). To increase stability of the three constructed plasmids in E. coli, superfluous vector sequences were removed and the virus expression cassettes were inserted between the plasmid replication origins and antibiotic selection markers in reverse orientation to the latter gene. Although the TEV cDNA in these three new plasmids is not interrupted by any exogenous sequence, they are more stable than the parental pTEV7DA during propagation in E. coli, indicating a major contribution of the plasmid context in virus cDNA stability. Using the different inocula produced from the three new plasmids the TEV infectivity was also compared. The results showed that agroinoculation is the most effective inoculation method and is where symptoms unfold earlier.

\section{Introduction}

Having virus infectious clones in plasmid vectors is an important landmark in the research of its molecular biology and interaction with hosts and transmission vectors. However, many times the resulting plasmids are unstable and degenerate during propagation in bacteria, limiting their usefulness (Boyer and Haenni, 1994). This problem is not infrequent in the long plus strand RNA viruses, like potyvirus, whose genome of about $9500 \mathrm{nt}$ involves a long cDNA insert in a plasmid vector. 
Tobacco etch virus (TEV) (Allison et al., 1986) infects numerous plant species and belongs to genus Potyvirus within the family Potyviridae and picorna-like virus supergroup (Koonin et al., 2008). The potyviral RNA genome is linked to a viral protein VPg at the 5' end and contains a poly $(\mathrm{A})$ tail at the 3 ' end. It encodes an open reading frame that is translated to a polyprotein which is processed, in a regulated manner, by three viral proteases yielding a total of approximately ten mature proteins (Riechmann et al., 1992). Nonetheless, the RNA may encode more proteins like the recently proposed P3-PIPO which could be expressed through ribosomal frameshifting or transcriptional slippage mechanisms (Chung et al., 2008). TEV has traditionally been one of the model viruses used in the research of potyvirus molecular biology and with this virus species some pioneering findings have been accomplished including: the identification and characterization of the viral proteases (Carrington et al., 1989, 1990; Dougherty et al., 1988), the subcellular localization of the viral proteins (Restrepo et al., 1990), important progresses in viral replication (Darós et al., 1999; Haldeman-Cahill et al., 1998; Schaad et al., 1997), translation (Khan et al., 2008; Niepel and Gallie, 1999) and movement (Dolja et al., 1992), to go in depth into the virus-host interaction (Agudelo- Romero et al., 2008a; Chisholm et al., 2000; Lellis et al., 2002) and the transmission by aphids (Ruiz-Ferrer et al., 2005) or the description of the first viral suppressor of RNA silencing (Kasschau and Carrington, 1998). More recently, this virus species has also been the object of interest as a model organism in experimental evolution of plant RNA viruses (Agudelo-Romero et al., 2008b; Carrasco et al., 2007; de la Iglesia and Elena, 2007; Torres-Barceló et al., 2010). And this is despite the only plasmid with a full-length clone of this virus commonly available to researchers (pTEV7DA), allowing production in vitro of infectious transcripts (Carrington et al., 1993; Dolja et al., 1993), is rather unstable when propagated in the bacterium Escherichia coli (Fig. 1A).

Several strategies have been proposed to solve the problem of instability of plasmid vectors containing RNA virus cDNAs during amplification in bacteria. Perhaps, the most accepted is the interruption of potentially toxic sequences in viral cDNA with introns, which are properly processed during viral RNA expression in the host. This strategy was proposed to stabilize a plasmid with a clone of the potyvirus Pea seedborne mosaic virus (Johansen, 1996) and has been successfully used with other potyviruses like Plum pox virus (López-Moya and García, 2000) or other RNA viruses including some from animal hosts (Gonzalez et al., 2002; Yamshchikov et al., 2001). This strategy requires, 
however, the interruption of the viral cDNA with exogenous sequences and the expression of the viral RNA from a DNA in the nucleus of the host cell which might not be desirable in some instances.
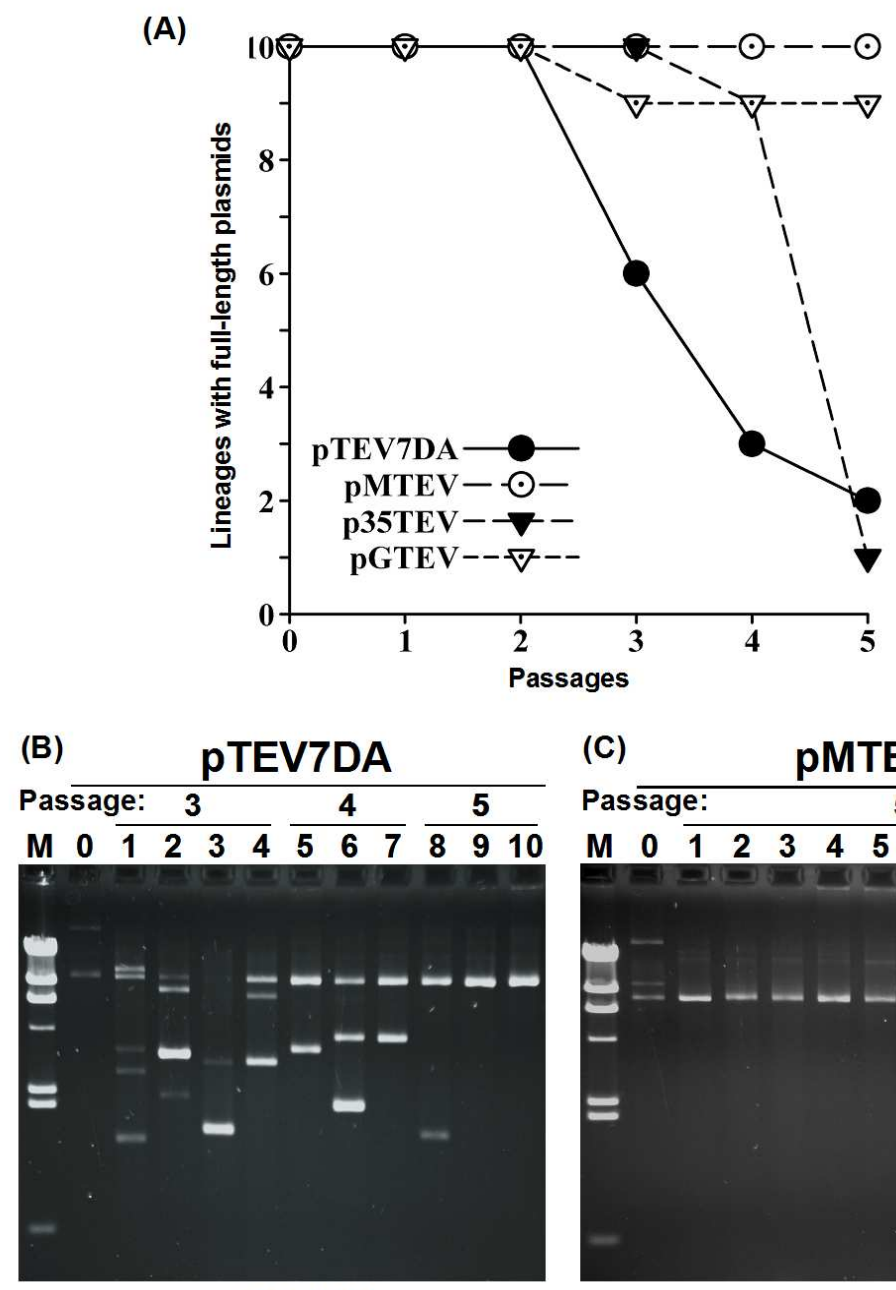

(C) PMTEV
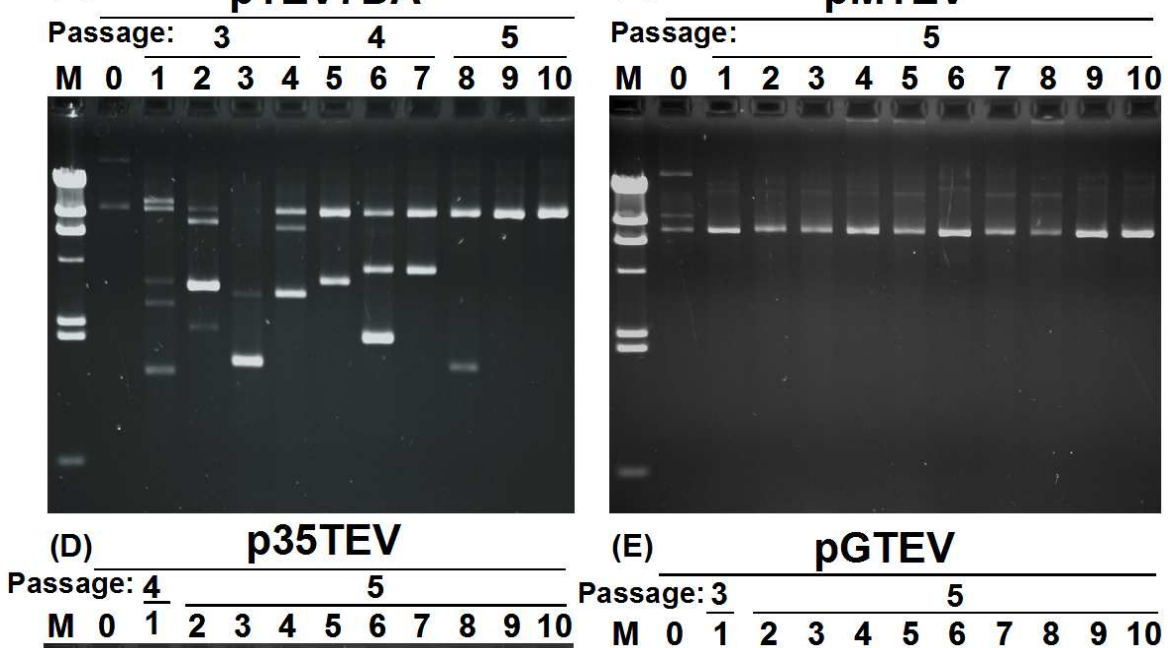

(E)
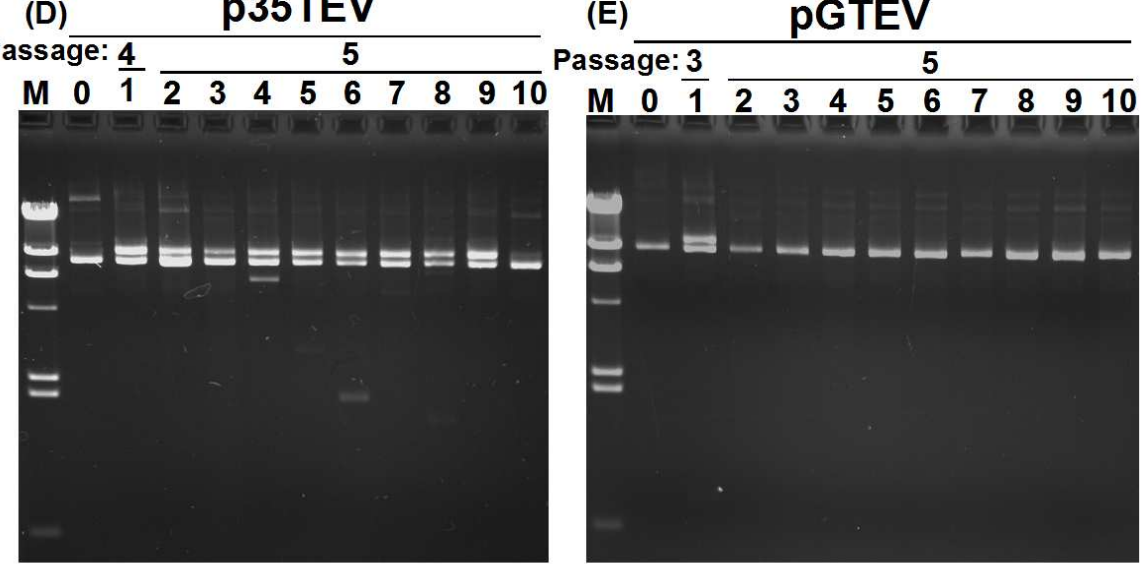

Fig. 1. Stability of the plasmids with a TEV infectious clone in E. coli. (A) Plot of the number of E. coli lineages keeping a full-length plasmid versus the passage number in liquid medium. pTEV7DA (solid circles), pMTEV (open circles), p35TEV (solid triangles) and pGTEV (open triangles). Plasmids that have lost integrity or reached passage 5 in the different $E$. coli lineages carrying pTEV7DA (B), pMTEV (C), p35TEV (D) and pGTEV (E). The passage number at the end of which the plasmid was purified is indicated. $M$, molecular mass marker, lambda phage DNA digested with EcoRI and HindIII. 
In the present work, the TEV infectious clone contained in plasmid pTEV7DA was taken as a starting point to construct three new plasmids that allowed infecting the host plants from RNA transcripts synthesized in vitro (pMTEV), directly from plasmid DNA (p35TEV) and by agroinoculation (pGTEV). The three new plasmids present substantially increased stability during propagation in $E$. coli compared to the parental pTEV7DA without the additional cost of interrupting the TEV cDNA by any exogenous sequence. This supports a major contribution of the plasmid context in virus cDNA stability. Finally, the infectivity of the three inocula that can be yielded by the three plasmids was compared showing superior performance of agroinoculation.

\section{Materials and methods}

\subsection{Plasmid construction}

Plasmid pMINI was obtained by PCR amplification of pUC18 (Genbank access no. L08752) using 5'-phosphorylated, divergent primers PI (5'-GGCGCGGCAGATCT GCGTTGCTGGCGTTTTTCC-3', Bglll site underlined, sequence complementary to pUC18 positions 2500-2518 in italics) and PII (5'-GCGCGCGGCGCGGC CCCGGGATGAGACAATAACCCTGA-3', Paul and Xmal sites underlined, sequence homologous to pUC18 positions 834-851 in italics), ligation of the PCR product with T4 DNA ligase (Fermentas) and transformation of $E$. coli $\mathrm{DH} 5 \alpha$ by electroporation (ECM 399, BTX). PCR amplifications were done in $20 \mu$ with $0.4 \mathrm{U}$ of the high fidelity Phusion DNA polymerase (Finnzymes) in HF buffer (Finnzymes), 3\% DMSO, $0.2 \mathrm{mM}$ dNTPs, $0.5 \mu \mathrm{M}$ each primer and $10 \mathrm{ng}$ template DNA. Reactions were incubated for $30 \mathrm{~s}$ at 98 ${ }^{\circ} \mathrm{C}$ followed by 30 cycles of $10 \mathrm{~s}$ at $98^{\circ} \mathrm{C}, 30 \mathrm{~s}$ at $55^{\circ} \mathrm{C}$ and $30 \mathrm{~s}$ at $72{ }^{\circ} \mathrm{C}$, and a final extension of $10 \mathrm{~min}$ at $72{ }^{\circ} \mathrm{C}$.

Plasmid pTEV7DA contains a TEV infectious clone (Genbank access no. DQ986288) flanked by SP6 phage RNA polymerase promoter and a unique Bglll site (Carrington et al., 1993; Dolja et al., 1993). It is original from Dr. James C. Carrington Laboratory (Oregon State University). From this plasmid, first, a DNA containing the SP6 promoter and a 5' fragment of TEV cDNA up to position 425 was amplified by PCR with primers PIII (5'-GGCGCGGCCCCGGGATTTAGGTGACAC-3', Xmal site underlined) and PIV (5'-CTCTTGCCATGGGTGAGCGCGCGAC-3', Paul site underlined). The PCR product digested with Xmal and Paul was inserted between the Xmal and Paul sites of pMINI. The inserted sequence in the resulting plasmid, pTEV2b, was confirmed by sequencing. 
Next, the Paul-Bglll fragment corresponding to the rest of the TEV cDNA was transferred from pTEV7DA to pTEV2b by DNA digestion and ligation. The resulting plasmid was named pMTEV (Fig. 2A and Fig. 1 supplementary).

The Cauliflower mosaic virus (CaMV) 35S promoter was amplified from plasmid pCAMBIA-2301 (Genbank access no. AF234316) with primers PV (5'-GGCGCGGC CCCGGGCGGCCGCGATTCCATTGCCCAG-3', Xmal and Notl sites underlined, sequence homologous to PCAMBIA-2301 positions 11,314-11,328 in italics) and PVI (5'- CCTCTCCAAATGAAATGAACTTCC-3', sequence complementary to pCAMBIA2301 positions $11,592-11,614$ in italics). This last primer was phosphorylated at the 5' end. The PCR product was digested with Xmal and ligated to the amplification product of pTEV2b with the divergent primers PII and PVII (5'-AAAATAACAAATCT CAACACAACATATAC-3', homologous to TEV DQ986288 positions 1-29) cut with Xmal. PVII was also phosphorylated at the 5' end. In the resulting plasmid, pTEV2c, the sequences of the 35S promoter and the 5' fragment of TEV cDNA was corroborated by sequencing. Next, a DNA with the CaMV 355 terminator was amplified from plasmid pCaMVW260 (Schoelz and Shepherd, 1988) with primers PVIII (5'-GGCGCGGC GCGCGCGGCGCGGCAGATCTCGCTGAAATCACC-3', Paul and Bglll sites underlined, sequence homologous to 35 S terminator in italics) and PIX (5'-GGCGCGG CGGATCCGGGCCCCTGGATTTTGGTTTTAGGAATTAG-3', BamHI and Apal sites underlined, sequence complementary to $35 S$ terminator in italics), was digested with Paul and BamHI and inserted between the Paul and Bglll sites of pTEV2c. The sequence of $35 S$ terminator was verified by sequencing in the resulting plasmid pTEV2d. Finally, most of the TEV cDNA (Paul-Bglll fragment) was transferred to this last plasmid by DNA digestion and ligation. The resulting plasmid was named p35TEV (Fig. 2B, and Fig. 2 supplementary). In plasmid pCLEAN-G181 (Genbank access no. EU186083) the compatible restriction sites Xhol and Sall were eliminated by DNA digestion and religation and the Bglll site by digestion, fill-in with Klenow DNA polymerase (Fermentas) and religation. To the resulting plasmid derived from pCLEANG181 the Notl-Apal DNA fragment from pTEV2d which contained the CaMV 35S promoter and 35S terminator flanking the 5' fragment of TEV cDNA was transferred and, next, the rest of TEV cDNA (Paul-Bglll fragment) from pTEV7DA. The resulting plasmid was named pGTEV (Fig. 2C and Fig. 3 supplementary). 


\subsection{Analysis of plasmid stability in E. coli}

Competent cells of $E$. coli DH5a were transformed by electroporation with plasmids pTEV7DA, pMTEV, p35TEV and pGTEV, respectively. The transformant clones were selected in LB ( $1 \%$ tryptone, $0.5 \%$ yeast extract, $1 \% \mathrm{NaCl}), 1.5 \%$ agar plates containing $50 \mu \mathrm{g} / \mathrm{ml}$ ampicillin (pTEV7DA, pMTEV and p35TEV) or $50 \mu \mathrm{g} / \mathrm{ml}$ kanamycin (pGTEV). For each plasmid, ten colonies were picked and grown in $3 \mathrm{ml}$ of LB liquid medium with $50 \mu \mathrm{g} / \mathrm{ml}$ carbenicillin (pTEV7DA, pMTEV and p35TEV) or $50 \mu \mathrm{g} / \mathrm{ml}$ kanamycin (pGTEV) at $37^{\circ} \mathrm{C}$ with $225 \mathrm{rpm}$ constant shaking. After $24 \mathrm{~h}$, each culture was refreshed by diluting ( $30 \mu \mathrm{l}$ in $3 \mathrm{ml}$ fresh medium) and growth was continued to a total of five passages in liquid culture. At the end of each passage, the plasmid present in each $E$. coli culture was analyzed by rapid extraction in a buffer:phenol:chloroform mix and electrophoresis separation in a 1\% agarose gel in TAE buffer (40 mM Tris, $20 \mathrm{mM}$ sodium acetate, $1 \mathrm{mM}$ EDTA, $\mathrm{pH}$ 7.2) as it has been previously described (Sanjuán and Darós, 2007). In those lineages where the plasmid had degenerated, it was purified from the culture with silica gel columns (Wizard plus SV minipreps, Promega) and the passages were interrupted.
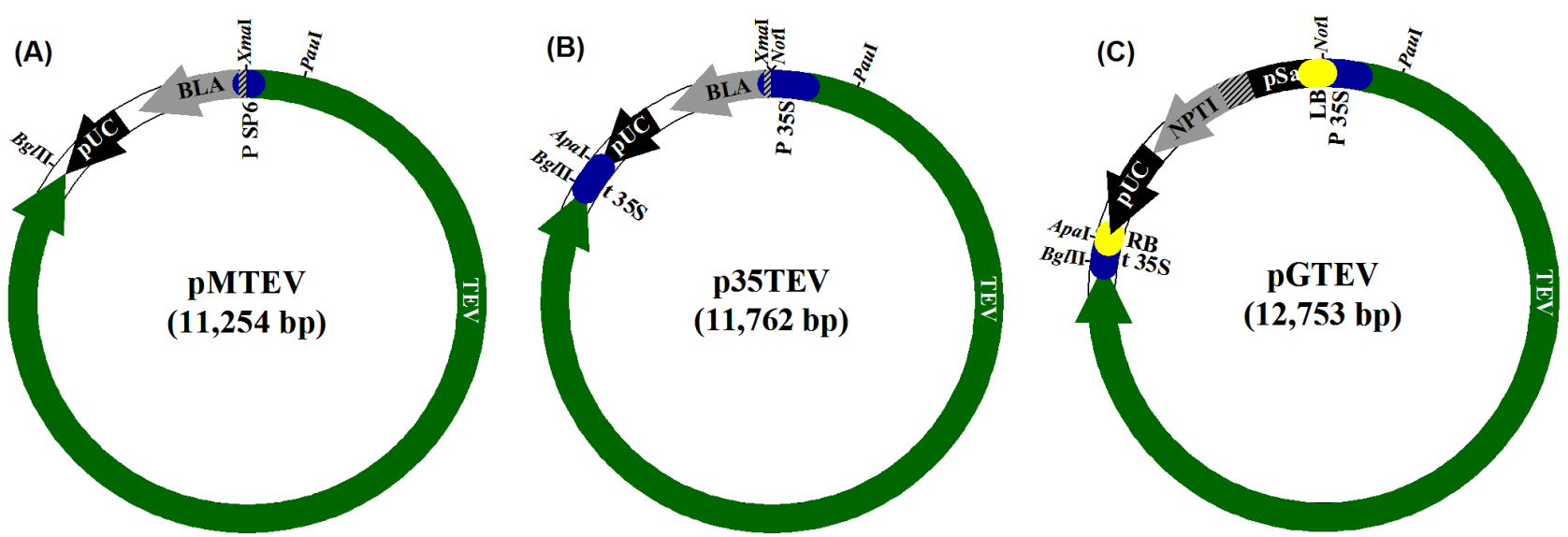

Fig. 2. Plasmids containing an infectious TEV cDNA. (A) Transcription vector pMTEV with an SP6 promoter (blue box), the TEV cDNA (green arrow), pUC replication origin (black arrow) and $\beta$-lactamase selection marker (BLA, gray arrow) with its promoter (striped gray box). (B) Expression vector p35TEV with CaMV $35 S$ promoter and terminator ( $P$ 35S and $t 35 S$, blue boxes). Other details as indicated in (A). (C) Binary vector pGTEV where the TEV expression cassette with $35 \mathrm{~S}$ promoter and terminator is flanked by the right and left borders of the T-DNA (RB and LB, respectively, yellow boxes). The plasmid also contains a pUC replication origin (pUC, black arrow), a pSa replication origin (black box) and kanamycin selection marker (NPTI, gray arroy) with its promoter (striped gray box). Other details as indicated in (B). In the schemes the positions of some restriction sites, particularly interesting, are also indicated. 


\subsection{Plant inoculation}

Plants of Nicotiana tabacum cv. Xhanti nc were grown in a greenhouse at $25 \stackrel{\circ}{ } \mathrm{C}$ with a photoperiod of $16 \mathrm{~h}$ day and $8 \mathrm{~h}$ night. Plants were inoculated at 1 -month age. To inoculate the plants with RNA transcripts obtained from pMTEV, $2 \mu \mathrm{g}$ of this plasmid, linearized with Bglll, were transcribed in a $50 \mu \mathrm{l}$ reaction with $125 \mathrm{U}$ SP6 RNA polymerase (Epicentre) in buffer $40 \mathrm{mM}$ Tris- $\mathrm{HCl}, \mathrm{pH} 8.0,6 \mathrm{mM} \mathrm{MgCl}, 20 \mathrm{mM}$ DTT, 2 $\mathrm{mM}$ spermidine, containing $0.5 \mathrm{mM}$ ATP, CTP and UTP, $50 \mu \mathrm{M}$ GTP, $0.5 \mathrm{mM}$ $\mathrm{m}^{7} \mathrm{G}\left[5^{\prime}\right] \mathrm{ppp}\left[5^{\prime}\right] \mathrm{G}$ (Epicentre), $50 \cup$ RNase inhibitor (Fermentas) and $0.25 \cup$ yeast inorganic pyrophosphatase (Fermentas) for $2 \mathrm{~h}$ at $37^{\circ} \mathrm{C}$. After $15 \mathrm{~min}$ of starting the reaction, it was supplemented with GTP to $0.5 \mathrm{mM}$. To quantify the full-length TEV transcript, an aliquot of the transcription reaction was analyzed by electrophoresis in a 1\% agarose gel in TBE buffer ( $89 \mathrm{mM}$ Tris, $89 \mathrm{mM}$ boric acid, $2 \mathrm{mM}$ EDTA) containing 1 $\mathrm{M}$ urea. The gel was stained with ethidium bromide and the amount of full-length TEV transcript estimated using an image analyzer and RNA standards included in the gel. The tobacco plants were inoculated mechanically by mixing on a leaf a volume of $5 \mu l$ containing different amounts of the TEV transcript reaction and $5 \mu \mathrm{l}$ of $10 \%$ carborundum in $100 \mathrm{mM} \mathrm{K}_{2} \mathrm{HPO}_{4}$ and spreading through the leaf surface with a glass rod. To inoculate plants with plasmid p35TEV, different amounts of this plasmid were mechanically inoculated as in the case of RNA. The plasmid was quantified by separating an aliquot by electrophoresis in a $1 \%$ agarose gel in TAE buffer, staining with ethidium bromide and estimating the amount of DNA with an image analyzer using DNA standards included in the same gel. Plasmid pGTEV was transformed in an Agrobacterium tumefaciens C58C1 strain containing the helper plasmid pCLEAN-S48 (Thole et al., 2007). Transformant bacteria were selected in LB agar plates containing $50 \mu \mathrm{g} / \mathrm{ml}$ rifampicin, $7.5 \mu \mathrm{g} / \mathrm{ml}$ tetracycline and $50 \mu \mathrm{g} / \mathrm{ml}$ kanamycin and, subsequently, were grown at $28^{\circ} \mathrm{C}$ in a liquid culture of LB containing the same antibiotics. Tobacco plants were infiltrated with $A$. tumefaciens using a syringe in two leaves (two infiltrations per leaf) in three different ways. (1) Colonies from a plate resuspended in buffer $10 \mathrm{mM}$ MES-NaOH, pH 5.6, $10 \mathrm{mM} \mathrm{MgCl}_{2}, 150 \mu \mathrm{M}$ acetosyringone and induced for $2 \mathrm{~h}$ at 28 ${ }^{\circ} \mathrm{C}$. (2) Directly with liquid culture grown to an optic density at $600 \mathrm{~nm}$ of approximately 0.5. (3) Cells from a liquid culture grown to an optic density of approximately 0.5 , sedimented by centrifugation, resuspended to an optic density of 0.5 in the same buffer as (1) and induced for $2 \mathrm{~h}$ at $28^{\circ} \mathrm{C}$. 


\section{Results}

\subsection{Instability of pTEV7DA in E. coli}

The transcription vector pTEV7DA (Carrington et al., 1993; Dolja et al., 1993) contains the TEV clone with Genbank access no. DQ986288. The synthesis in vitro of an RNA with 5' cap structure from this plasmid linearized with Bglll by SP6 RNA polymerase produces the TEV RNA with an extra G at the 5' end and a 3' poly $(A)$ tail of 45 nt which is highly infectious when inoculated into tobacco plants. This plasmid is, however, unstable during its propagation in E. coli. To measure the tendency of this plasmid to degenerate during its amplification in E. coli and to compare it with that of other plasmids with the same TEV infectious clone, an assay was designed consisting of passaging $E$. coli lineages that carried the different plasmids in liquid cultures and analyzing the plasmid integrity at the end of each passage. From ten $E$. coli colonies transformed with pTEV7DA, ten lineages growing in liquid medium were established and refreshed each $24 \mathrm{~h}$ by 1:100 dilution in fresh medium, which corresponds to approximately 6.64 generations of binary fission per day. Plasmid integrity in each lineage was followed by electrophoresis at the end of each passage (Fig. 1A and B). In those lineages where the plasmid had degenerated, it was purified and the passages interrupted. During propagation of pTEV7DA, degenerated forms of the plasmid appeared in four lineages at passage 3 (Fig. 1B, lanes 1-4), in three lineages at passage 4 (Fig. 1B, lanes 5-7), and in an additional lineage at passage 5 (Fig. 1B, lane 8). Only two lineages kept the full-length plasmid after five passages (Fig. 1B, lanes 9 and 10). Inoculation of tobacco plants with in vitro transcripts produced from these two plasmids led to infections with the typical etching of TEV (Table 1). Some of the PTEV7DA degenerated forms were eluted from the agarose gel and characterized by restriction enzyme reactions as well as sequencing. The results showed the presence of extensive deletions in the TEV cDNA.

\subsection{Construction of new plasmids with the TEV cDNA infectious clone}

Starting from the TEV infectious clone contained in plasmid pTEV7DA three new plasmids were constructed that would allow inoculating plants from in vitro transcripts, directly from plasmid DNA and by agroinoculation. The new plasmids were rationally designed to increase their stability in E. coli without modifying or interrupting the TEV 
cDNA with exogenous sequences. In any case, the stability of these new plasmids was contrasted with that of the original pTEV7DA by the assay consisting of passaging ten independent lineages of $E$. coli bearing the different plasmids. The new plasmid pMTEV contained the same transcription cassette as pTEV7DA (Fig. 2A and Fig. 1 supplementary). Transcription in vitro with SP6 RNA polymerase produced a full-length TEV RNA with an extra 5'-G and a 45 nt 3' poly $(A)$ tail. But, to increase plasmid stability in E. coli, this transcription cassette was inserted into a pUC18 minimal version of 1713 bp (pMINI) with all sequences considered to be superfluous being removed, out of a minimal replication origin, the $\beta$-lactamase selection marker and a short polylinker. Moreover, the transcription cassette was introduced between the replication origin and the selection marker in reverse orientation to $\beta$-lactamase gene to avoid transcription of any kind of mRNA that could end with translation of TEV polyprotein in bacteria. The new plasmid resulted to be highly stable in $E$. coli, since the full-length plasmid was recovered in the stability assay from the ten independent lineages after five passages in liquid culture (Fig. 1A and C, lanes 1-10). From the plasmids purified from the cultures after the fifth passage, 5'-capped transcripts were synthesized in vitro and tobacco plants inoculated. These transcripts were highly infectious inducing a disease with the typical TEV etching symptoms (Table 1). Next, a plasmid designed to infect plants directly from DNA was constructed, p35TEV (Fig. 2B and Fig. 2 supplementary). The TEV cDNA was flanked by CaMV 35S promoter and terminator and this cassette inserted between the replication origin and the $\beta$-lactamase selection marker of pMINI also in reverse orientation to this last gene. The transcription in vivo mediated by the RNA polymerase II from the $35 \mathrm{~S}$ promoter must produce a full-length TEV transcript including an extra 5'-G and a 45 nt long 3' poly $(A)$ tail which would be followed by sequences transcribed from the $35 \mathrm{~S}$ terminator. In the stability assay, p35TEV resulted less stable than its predecessor pMTEV but more than the ancestral pTEV7DA (Fig. $1 \mathrm{~A})$. The plasmid in one of the ten $E$. coli lineages degenerated during passage 4 to a slower form (Fig. 1D, lane 1) and the same occurred in eight additional lineages during passage 5 (Fig. 1D, lanes 2-9). Only one lineage maintained a full-length plasmid along the five passages (Fig. 1D, lane 10). This plasmid, purified after passage 5, was inoculated into tobacco and produced the typical symptoms of TEV disease (Table 1). Some of the slower forms of p35TEV were eluted from the agarose gel and electroporated into $E$. coli for amplification. However, after several attempts 
transformant clones were never obtained, precluding further characterization of these forms.

Finally, a third plasmid to agroinoculate plants was constructed, pGTEV (Fig. 2C and Fig. 3 supplementary). The expression cassette with the TEV cDNA flanked by CaMV 35S promoter and terminator of p35TEV was inserted between the right and left borders of the T-DNA in amodified version of pCLEAN-G181 (Thole et al., 2007). This vector contains a small pCLEAN-type T-DNA, double left border and right border with right border overdrive sequence. It requires the helper plasmid pSoup (Hellens et al.,2000) or some of its derivatives (Thole et al., 2007) to replicate in $A$. tumefaciens. The resulting plasmid was more stable in $E$. coli than its parental p35TEV (Fig. 1A). Only in one lineage the integrity of the plasmid was lost during passage 3 (Fig. 1E, lane 1). The rest of the lineages maintained the full-length plasmid along the five passages (Fig. 1E, lanes 2-10). The plasmids present in these nine lineages were purified after passage 5 and used to transform $A$. tumefaciens C58C1 carrying helper plasmid pCLEAN-S48. With the cultures of the resulting $A$. tumefaciens clones, tobacco plants were agroinoculated and developed the typical TEV etching (Table 1).

\subsection{Comparative TEV infection with inocula obtained from the three new plasmids}

Having three new plasmids at hand that allowed inoculating plants with the same TEV infectious clone through three different manners, an experiment to compare these three inoculation procedures from a practical view was designed. The infectivity of different amounts of 5' capped RNA transcripts obtained in vitro from pMTEV was compared with that of the same amounts of plasmid p35TEV. In the comparison three modalities of plant agroinoculation with $A$. tumefaciens transformed with pGTEV were also included. Batches of ten tobacco plants were inoculated in one leaf with 1, 0.1 and $0.01 \mathrm{pmol}$ of full-length TEV in vitro transcripts or, directly, with plasmid p35TEV DNA. Likewise, batches of ten plants were agroinoculated with an $A$. tumefaciens culture in which the bacteria were washed and induced with acetosyringone, directly with the liquid culture without washing and inducing, or with $A$. tumefaciens colonies from a plate resuspended in buffer and induced. When 1 pmol of full-length TEV transcript was inoculated, $70 \%$ of the plants were infected (Fig. 3). With 0.1 pmol of transcript only $20 \%$ became infected and none were infected with 0.01 pmol (Fig. 3). Using 1, 0.1 and 0.01 pmol of p35TEV DNA per plant 100,80 and $60 \%$ of the plants became infected, 
respectively (Fig. 3). In contrast, $100 \%$ of the plants were infected through the three modalities of agroinoculation assayed (Fig. 3). In general, disease symptoms emerged between days 4 and 6 postinoculation, with the agroinoculated plants being amongst the earliest to show the symptoms. All agroinoculated plants showed symptoms 4 days postinoculation but one, agroinoculated with colonies, showed them at day 5.

Table 1. Inoculation of tobacco plants with inocula obtained from plasmids with a TEV infectious clone purified after five passages of $24 \mathrm{~h}$ in E. coli.

\begin{tabular}{|c|c|c|}
\hline Plasmid & Lineage & Number plants infected/inoculated* \\
\hline \multirow{2}{*}{ PTEV7DA } & 9 & $4 / 5$ \\
\hline & 10 & $5 / 5$ \\
\hline \multirow{10}{*}{ pMTEV } & 1 & $5 / 5$ \\
\hline & 2 & $5 / 5$ \\
\hline & 3 & $4 / 5$ \\
\hline & 4 & $4 / 5$ \\
\hline & 5 & $5 / 5$ \\
\hline & 6 & $5 / 5$ \\
\hline & 7 & $5 / 5$ \\
\hline & 8 & $5 / 5$ \\
\hline & 9 & $5 / 5$ \\
\hline & 10 & $4 / 5$ \\
\hline P35TEV & 10 & $4 / 6$ \\
\hline \multirow{9}{*}{ pGTEV } & 2 & $6 / 6$ \\
\hline & 3 & $6 / 6$ \\
\hline & 4 & $6 / 6$ \\
\hline & 5 & $6 / 6$ \\
\hline & 6 & $6 / 6$ \\
\hline & 7 & $6 / 6$ \\
\hline & 8 & $6 / 6$ \\
\hline & 9 & $6 / 6$ \\
\hline & 10 & $6 / 6$ \\
\hline
\end{tabular}

${ }^{*}$ Results 7 days postinoculation. 


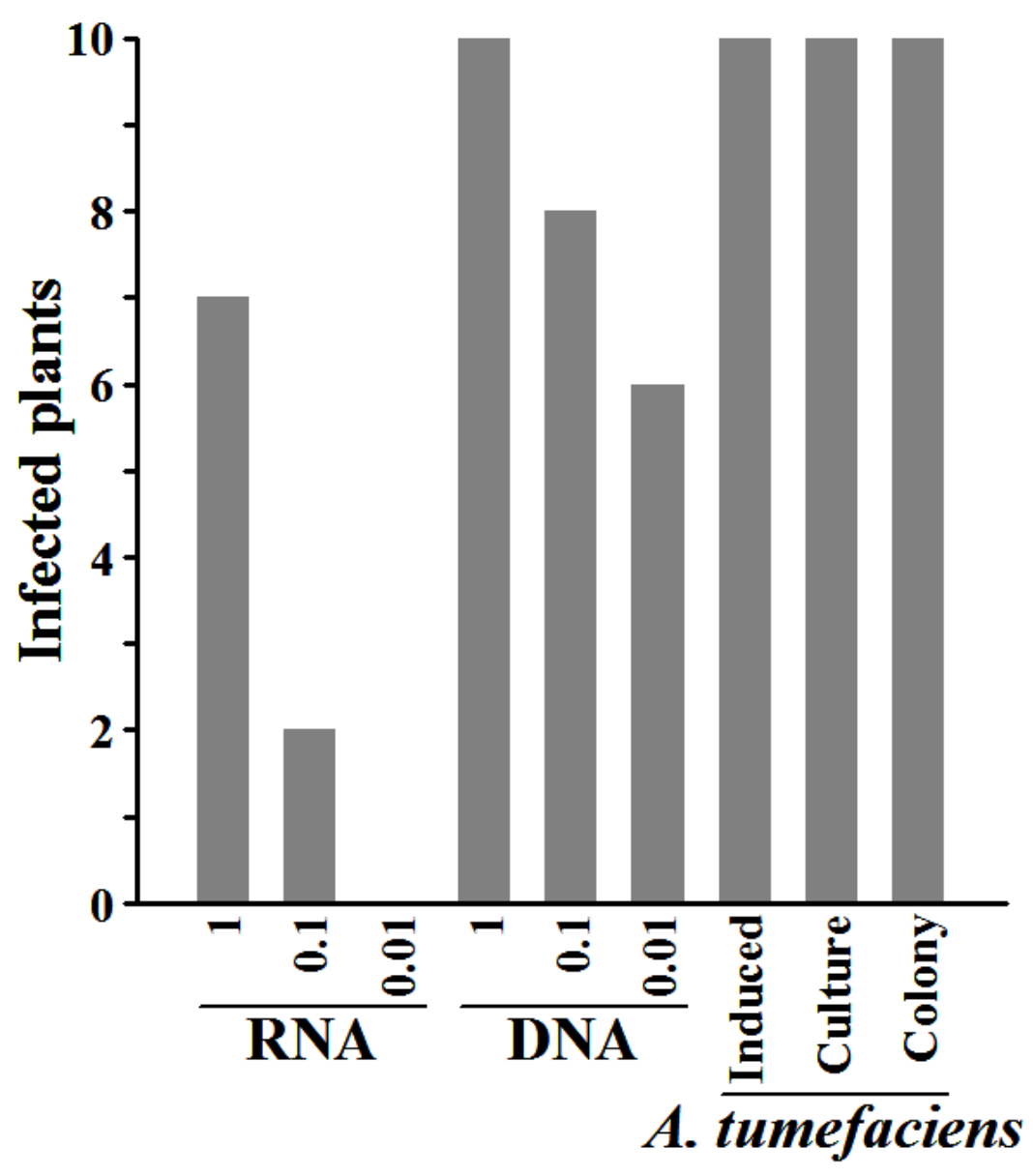

Fig. 3. Graph of the number of TEV infected tobacco plants from different inocula. Results are shown 7 days after inoculation with $1,0.1$ and 0.01 pmol of full-length TEV RNA synthesized in vitro from pMTEV (RNA), of plasmid p35TEV (DNA) or by agroinoculation ( $A$. tumefaciens) through three different ways using washed and induced bacteria (induced), directly bacteria from a liquid culture (culture) and bacterial colonies resuspended from a plate and induced (colony).

\section{Discussion}

Infectious clones of RNA viruses in plasmid vectors are a fundamental tool to research the virus molecular biology and, many times, these constructions are the starting point to design virus based expression vectors useful in biotechnological applications (Lico et al., 2008). Nonetheless, these plasmids are often unstable when propagated in bacteria like E. coli and sequence alterations, such as point mutations and deletions, are produced during culture (Boyer and Haenni, 1994). Amongst the reasons proposed to explain this instability stands the toxicity of the viral cDNA inside the bacteria or, more explicitly, the toxicity of the viral gene products expressed from promoters either present in the plasmid or cryptic in the viral cDNA but active in bacteria. To overcome this limitation different strategies have been proposed. The most accepted consists of interrupting the viral cDNA with introns that avoid the expression of the viral toxic 
product in bacteria and that are properly processed by splicing in the host (Johansen, 1996). This strategy has some drawbacks such as the undesired increment in plasmid size, that is only applicable to plasmids devoted to trigger infection from a DNA expressed in the cell nucleus and, in some cases, it might become inconvenient interrupting the viral cDNA with exogenous sequences. Another strategy successfully used in the case of Citrus tristeza virus involves a compromise between infectivity and stability and consists of the introduction of mutations changing the translation frame in slippery regions next to the toxic viral sequences (Satyanarayana et al., 2003). In any case, the plasmid instability problems could also be potentially solved by simpler strategies like changing the E. coli strain, the growth temperature or changing the plasmid vector in those cases where vector sequences or the combination between vector and viral sequences have an important role. pTEV7DA (Carrington et al., 1993; Dolja et al., 1993) is a plasmid with an infectious clone of TEV, a model plant RNA virus belonging to the family Potyviridae, commonly available to research. This plasmid is, however, unstable when propagated in E. coli as it is shown in the stability assay based on passaging $E$. coli lineages carrying this plasmid in successive liquid cultures (Fig. 1). To circumvent this limitation, in the present work three new plasmids containing the same TEV cDNA as in pTEV7DA have been designed and constructed (Fig. 2). The plasmids design was rationalized trying to improve stability in $E$. coli without resorting to virus cDNA interruption with exogenous intron sequences. These three new plasmids resulted to be more stable than the ancestral pTEV7DA in the stability assay (Fig. 1). The rules for designing the new plasmids were to keep the vector backbone to a minimum size by deleting all superfluous sequences (Strathmann et al., 1991) and to insert TEV expression cassettes between the plasmid replication origin and the antibiotic selection marker in reverse orientation to this last gene (Fig. 2). This way, the possibilities of expression of TEV polyprotein in bacteria as a consequence of vector promoters or vector cryptic promoters must be negligible. As a matter of fact, pMTEV that contains exactly the same transcription cassette as pTEV7DA resulted to be highly stable during propagation in E. coli (Fig. 1). However, in p35TEV where exclusively sequences corresponding to CaMV 35S promoter and terminator were added, stability decreased (Fig. 1), possibly due to some activity of eukaryotic 35S promoter in bacteria as has previously been reported (Assaad and Signer, 1990). Interestingly, when the same expression cassette of p35TEV was moved to a binary plasmid, the resulting plasmid, pGTEV, increased stability (Fig. 1). These results illustrate the influence of the 
context in the stability of long viral cDNAs, like those from potyvirus, in plasmid vectors and may aid in to the rational design of this kind of constructions. The three new plasmids allow inoculating plants with the same TEV infectious clone from RNA (pMTEV) and DNA (p35TEV) and by agroinoculation (pGTEV). Although the choice of inoculum will mainly depend on the specific objectives pursued, a comparative inoculation from a practical view using the three inocula (Fig. 3) showed that, in the case of TEV, agroinoculation is the most effective method and in which symptoms show the earliest. Moreover, the agroinoculation process can be fairly simplified without a significant loss in infectivity (Fig. 3). Inoculation with RNA and DNA may be effective enough, in those cases in which agroinoculation is not desirable. In the present comparison, DNA was more infective than RNA. However, it must be taken into account that in the assay the molar amounts of plasmid p35TEV and full-length in vitro RNA transcripts from pMTEV were normalized but only an unknown fraction of the latter is expected to be properly capped at the 5' end, a feature that is needed to unleash infection from RNA in the case of TEV. In short, having three plasmids with the same TEV infectious clone that are stable when propagating in $E$. coli and that allow infecting plants with RNA, DNA or by agroinoculation expands the possibilities of using this model virus to research many aspects of potyvirus molecular biology and experimental evolution.

\section{Acknowledgements}

This work was supported by grants BIO2008-01986 from Ministerio de Ciencia e Innovación from Spain and ACOMP/2009/042 from Generalitat Valenciana (to J.A.D). We thank Dr. James C. Carrington (Oregon State University, USA) for providing plasmid pTEV7DA and Drs. Santiago F. Elena (IBMCP, CSIC-UPV, Valencia, Spain) and Mario Fares (IBMCP, CSIC-UPV, Valencia, Spain and University of Dublin, Trinity College, Dublin, Ireland) for their suggestions, advice and critical reading of the manuscript.

\section{References}

Agudelo-Romero, P., Carbonell, P., de la Iglesia, F., Carrera, J., Rodrigo, G., Jaramillo, A., Pérez-Amador, M.A., Elena, S.F., 2008a. Changes in the gene expression profile of Arabidopsis thaliana after infection with Tobacco etch virus. Virol. J. 5, 92. 
Agudelo-Romero, P., Carbonell, P., Perez-Amador, M.A., Elena, S.F., 2008b. Virus adaptation by manipulation of host's gene expression. PLoS One 3, e2397.

Allison, R., Johnston, R.E., Dougherty, W.G., 1986. The nucleotide sequence of the coding region of tobacco etch virus genomic RNA: evidence for the synthesis of a single polyprotein. Virology 154, 9-20.

Assaad, F.F., Signer, E.R., 1990. Cauliflower mosaic virus P35S promoter activity in Escherichia coli. Mol. Gen. Genet. 223, 517-520.

Boyer, J.C., Haenni, A.L., 1994. Infectious transcripts and cDNA clones of RNA viruses. Virology 198, 415-426.

Carrasco, P., de la Iglesia, F., Elena, S.F., 2007. Distribution of fitness and virulence effects caused by single-nucleotide substitutions in Tobacco etch virus. J. Virol. 81, 12979-12984.

Carrington, J.C., Cary, S.M., Parks, T.D., Dougherty, W.G., 1989. A second proteinase encoded by a plant potyvirus genome. EMBO J. 8, 365-370.

Carrington, J.C., Freed, D.D., Oh, C.S., 1990. Expression of potyviral polyproteins in transgenic plants reveals three proteolytic activities required for complete processing. EMBO J. 9, 1347-1353.

Carrington, J.C., Haldeman, R., Dolja, V.V., Restrepo-Hartwig, M.A., 1993. Internal cleavage and trans-proteolytic activities of the VPg-proteinase (NIa) of tobacco etch potyvirus in vivo. J. Virol. 67, 6995-7000.

Chisholm, S.T., Mahajan, S.K., Whitham, S.A., Yamamoto, M.L., Carrington, J.C., 2000. Cloning of the Arabidopsis RTM1 gene, which controls restriction of long-distance movement of tobacco etch virus. Proc. Natl. Acad. Sci. U.S.A. 97, 489-494.

Chung, B.Y., Miller, W.A., Atkins, J.F., Firth, A.E., 2008. An overlapping essential gene in the Potyviridae. Proc. Natl. Acad. Sci. U.S.A. 105, 5897-5902.

Daròs, J.A., Schaad, M.C., Carrington, J.C., 1999. Functional analysis of the interaction between VPg-proteinase (NIa) and RNA polymerase (NIb) of tobacco etch potyvirus, using conditional and suppressor mutants. J. Virol. 73, 8732-8740.

de la Iglesia, F., Elena, S.F., 2007. Fitness declines in Tobacco etch virus upon serial bottleneck transfers. J. Virol. 81, 4941-4947.

Dolja, V.V., Herndon, K.L., Pirone, T.P., Carrington, J.C., 1993. Spontaneous utagenesis of a plant potyvirus genome after insertion of a foreign gene. J. Virol. 67 , 5968-5975. 
Dolja, V.V., McBride, H.J., Carrington, J.C., 1992. Tagging of plant potyvirus replication and movement by insertion of $\beta$-glucuronidase into the viral polyprotein. Proc. Natl. Acad. Sci. U.S.A. 89, 10208-10212.

Dougherty, W.G., Carrington, J.C., Cary, S.M., Parks, T.D., 1988. Biochemical and mutational analysis of a plant virus polyprotein cleavage site. EMBO J. 7, 12811287.

Gonzalez, J.M., Penzes, Z., Almazan, F., Calvo, E., Enjuanes, L., 2002. Stabilization of a full-length infectious cDNA clone of transmissible gastroenteritis coronavirus by insertion of an intron. J. Virol. 76, 4655-4661.

Haldeman-Cahill, R., Daròs, J.A., Carrington, J.C., 1998. Secondary structures in the capsid protein coding sequence and 3' nontranslated region involved in amplification of the tobacco etch virus genome. J. Virol. 72, 4072-4079.

Hellens, R.P., Edwards, E.A., Leyland, N.R., Bean, S., Mullineaux, P.M., 2000. pGreen: a versatile and flexible binary $\mathrm{Ti}$ vector for Agrobacterium-mediated plant transformation. Plant Mol. Biol. 42, 819-832.

Johansen, I.E., 1996. Intron insertion facilitates amplification of cloned virus cDNA in Escherichia coli while biological activity is reestablished after transcription in vivo. Proc. Natl. Acad. Sci. U.S.A. 93, 12400-12405.

Kasschau, K.D., Carrington, J.C., 1998. A counterdefensive strategy of plant viruses: suppression of posttranscriptional gene silencing. Cell 95, 461-470.

Khan, M.A., Miyoshi, H., Gallie, D.R., Goss, D.J., 2008. Potyvirus genome-linked protein, VPg, directly affects wheat germ in vitro translation: interactions with translation initiation factors elF4F and elFiso4F. J. Biol. Chem. 283, 1340-1349.

Koonin, E.V., Wolf, Y.I., Nagasaki, K., Dolja, V.V., 2008. The Big Bang of picorna-like virus evolution antedates the radiation of eukaryotic supergroups. Nat. Rev. Microbiol. 6, 925-939.

Lellis, A.D., Kasschau, K.D., Whitham, S.A., Carrington, J.C., 2002. Loss-of susceptibility mutants of Arabidopsis thaliana reveal an essential role for elF(iso)4E during potyvirus infection. Curr. Biol. 12, 1046-1051.

Lico, C., Chen, Q., Santi, L., 2008. Viral vectors for production of recombinant proteins in plants. J. Cell Physiol. 216, 366-377.

López-Moya, J.J., García, J.A., 2000. Construction of a stable and highly infectious intron-containing cDNA clone of plum pox potyvirus and its use to infect plants by particle bombardment. Virus Res. 68, 99-107. 
Niepel, M., Gallie, D.R., 1999. Identification and characterization of the functional elements within the tobacco etch virus 5' leader required for cap-independent translation. J. Virol. 73, 9080-9088.

Restrepo, M.A., Freed, D.D., Carrington, J.C., 1990. Nuclear transport of plant potyviral proteins. Plant Cell 2, 987-998.

Riechmann, J.L., Laín, S., García, J.A., 1992. Highlights and prospects of potyvirus molecular biology. J. Gen. Virol. 73, 1-16.

Ruiz-Ferrer, V., Boskovic, J., Alfonso, C., Rivas, G., Llorca, O., López-Abella, D., López- Moya, J.J., 2005. Structural analysis of tobacco etch potyvirus HC-Pro oligomers involved in aphid transmission. J. Virol. 79, 3758-3765.

Sanjuán, R., Daròs, J.A., 2007. One-step site-directed mutagenesis of viroid dimeric cDNA. J. Virol. Methods 145, 71-75.

Satyanarayana, T., Gowda, S., Ayllón, M.A., Dawson, W.O., 2003. Frameshift mutations in infectious cDNA clones of Citrus tristeza virus: a strategy to minimize the toxicity of viral sequences to Escherichia coli. Virology 313, 481-491.

Schaad, M.C., Jensen, P.E., Carrington, J.C., 1997. Formation of plant RNA virus replication complexes on membranes: role of an endoplasmic reticulum-targeted viral protein. EMBO J. 16, 4049-4059.

Schoelz, J.E., Shepherd, R.J., 1988. Host range control of cauliflower mosaic-virus. Virology 162, 30-37.

Strathmann, M., Hamilton, B.A., Mayeda, C.A., Simon, M.I., Meyerowitz, E.M., Palazzolo, M.J., 1991. Transposon-facilitated DNA sequencing. Proc. Natl. Acad. Sci. U.S.A. 88, 1247-1250.

Thole, V., Worland, B., Snape, J.W., Vain, P., 2007. The pCLEAN dual binary vector system for Agrobacterium-mediated plant transformation. Plant Physiol. 145, 12111219.

Torres-Barceló, C., Darós, J.A., Elena, S.F., 2010. Compensatory molecular evolution of HC-Pro, an RNA-silencing suppressor from a plant virus. Mol. Biol. Evol. 27, 543-551.

Yamshchikov, V., Mishin, V., Cominelli, F., 2001. A new strategy in design of (+)RNA virus infectious clones enabling their stable propagation in E. coli. Virology 281, 272-280. 


\section{Supplementary material}

Fig. 1 supplementary. Sequence of transcription vector pMTEV $(11,254 \mathrm{bp})$ which contains an infectious TEV cDNA clone (Genebank access no. DQ986288). The sequences corresponding to the SP6 promoter (blue, transcription +1 nucleotide underlined), the minimal pUC replication origin (light gray), the $\beta$-lactamase open reading frame (dark gray, complementary sequence) and the unique restriction sites Paul, Bglll and Xmal (green) are marked. The in vitro transcription with SP6 RNA polymerase of this plasmid linearized with Bglll produces an RNA of $9,541 \mathrm{nt}$ (first and last positions of this transcript underlined).

ATTTAGGTGACACTATAGAAAATAACAAATCTCAACACAACATATACAAAACAAACGAATCTCAAGCAATCAAGCATTCTACTTCTATTGCAGCAAT TTAAATCATTTCTTTTAÄAGCAAAAGCAATTTTCTGAAAATTTTCACCATTTACGAACGATAGCCATGGCACTCATCTTTGGCACAGTCAACGCTAA CATCCTGAAGGAAGTGTTCGGTGGAGCTCGTATGGCTTGCGTTACCAGCGCACATATGGCTGGAGCGAATGGAAGCATTTTGAAGAAGGCAGAAGAG ACCTCTCGTGCAATCATGCACAAACCAGTGATCTTCGGAGAAGACTACATTACCGAGGCAGACTTGCCTTACACACCACTCCATTTAGAGGTCGATG CTGAAATGGAGCGGATGTATTATCTTGGTCGTCGCGCGCTCACCCATGGCAAGAGACGCAAAGTTTCTGTGAATAACAAGAGGAACAGGAGAAGGAA AGTGGCCAAAACGTACGTGGGGCGTGATTCCATTGTTGAGAAGATTGTAGTGCCCCACACCGAGAGAAAGGTTGATACCACAGCAGCAGTGGAAGAC ATTTGCAATGAAGCTACCACTCAACTTGTGCATAATAGTATGCCAAAGCGTAAGAAGCAGAAAAACTTCTTGCCCGCCACTTCACTAAGTAACGTGT ATGCCCAAACTTGGAGCATAGTGCGCAAACGCCATATGCAGGTGGAGATCATTAGCAAGAAGAGCGTCCGAGCGAGGGTCAAGAGATTTGAGGGCTC GGTGCAATTGTTCGCAAGTGTGCGTCACATGTATGGCGAGAGGAAAAGGGTGGACTTACGTATTGACAACTGGCAGCAAGAGACACTTCTAGACCTT GCTAAAAGATTTAAGAATGAGAGAGTGGATCAATCGAAGCTCACTTTTGGTTCAAGTGGCCTAGTTTTGAGGCAAGGCTCGTACGGACCTGCGCATT GGTATCGACATGGTATGTTCATTGTACGCGGTCGGTCGGATGGGATGTTGGTGGATGCTCGTGCGAAGGTAACGTTCGCTGTTTGTCACTCAATGAC ACATTATAGCGACAAATCAATCTCTGAGGCATTCTTCATACCATACTCTAAGAAATTCTTGGAGTTGAGACCAGATGGAATCTCCCATGAGTGTACA AGAGGAGTATCAGTTGAGCGGTGCGGTGAGGTGGCTGCAATCCTGACACAAGCACTTTCACCGTGTGGTAAGATCACATGCAAACGTTGCATGGTTG AAACACCTGACATTGTTGAGGGTGAGTCGGGAGACAGTGTCACCAACCAAGGTAAGCTCCTAGCAATGCTGAAAGAACAGTATCCAGATTTCCCAAT GGCCGAGAAACTACTCACAAGGTTTTTGCAACAGAAATCACTAGTAAATACAAATTTGACAGCCTGCGTGAGCGTCAAACAACTCATTGGTGACCGC AAACAAGCTCCATTCACACACGTACTGGCTGTCAGCGAAATTCTGTTTAAAGGCAATAAACTAACAGGGGCCGATCTCGAAGAGGCAAGCACACATA TGCTTGAAATAGCAAGGTTCTTGAACAATCGCACTGAAAATATGCGCATTGGCCACCTTGGTTCTTTCAGAAATAAAATCTCATCGAAGGCCCATGT GAATAACGCACTCATGTGTGATAATCAACTTGATCAGAATGGGAATTTTATTTGGGGACTAAGGGGTGCACACGCAAAGAGGTTTCTTAAAGGATTT TTCACTGAGATTGACCCAAATGAAGGATACGATAAGTATGTTATCAGGAAACATATCAGGGGTAGCAGAAAGCTAGCAATTGGCAATTTGATAATGT CAACTGACTTCCAGACGCTCAGGCAACAAATTCAAGGCGAAACTATTGAGCGTAAAGAAATTGGGAATCACTGCATTTCAATGCGGAATGGTAATTA CGTGTACCCATGTTGTTGTGTTACTCTTGAAGATGGTAAGGCTCAATATTCGGATCTAAAGCATCCAACGAAGAGACATCTGGTCATTGGCAACTCT GGCGATTCAAAGTACCTAGACCTTCCAGTTCTCAATGAAGAGAAAATGTATATAGCTAATGAAGGTTATTGCTACATGAACATTTTCTTTGCTCTAC TAGTGAATGTCAAGGAAGAGGATGCAAAGGACTTCACCAAGTTTATAAGGGACACAATTGTTCCAAAGCTTGGAGCGTGGCCAACAATGCAAGATGT TGCAACTGCATGCTACTTACTTTCCATTCTTTACCCAGATGTCCTGAGTGCTGAATTACCCAGAATTTTGGTTGATCATGACAACAAAACAATGCAT GTTTTGGATTCGTATGGGTCTAGAACGACAGGATACCACATGTTGAAAATGAACACAACATCCCAGCTAATTGAATTCGTTCATTCAGGTTTGGAAT CCGAAATGAAAACTTACAATGTTGGAGGGATGAACCGAGATATGGTCACACAAGGTGCAATTGAGATGTTGATCAAGTCCATATACAAACCACATCT CATGAAGCAGTTACTTGAGGAGGAGCCATACATAATTGTCCTGGCAATAGTCTCCCCTTCAATTTTAATTGCCATGTACAACTCTGGAACTTTTGAG CAGGCGTTACAAATGTGGTTGCCAAATACAATGAGGTTAGCTAACCTCGCTGCCATCTTGTCAGCCTTGGCGCAAAAGTTAACTTTGGCAGACTTGT TCGTCCAGCAGCGTAATTTGATTAATGAGTATGCGCAGGTAATTTTGGACAATCTGATTGACGGTGTCAGGGTTAACCATTCGCTATCCCTAGCAAT GGAAATTGTTACTATTAAGCTGGCCACCCAAGAGATGGACATGGCGTTGAGGGAAGGTGGCTATGCTGTGACCTCTGAAAAGGTGCATGAAATGTTG GAAAAAAACTATGTAAAGGCTTTGAAGGATGCATGGGACGAATTAACTTGGTTGGAAAAATTCTCCGCAATCAGGCATTCAAGAAAGCTCTTGAAAT TTGGGCGAAAGCCTTTAATCATGAAAAACACCGTAGATTGCGGCGGACATATAGACTTGTCTGTGAAATCGCTTTTCAAGTTCCACTTGGAACTCCT GAAGGGAACCATCTCAAGAGCCGTAAATGGTGGTGCAAGAAAGGTAAGAGTAGCGAAGAATGCCATGACAAAAGGGGTTTTTCTCAAAATCTACAGC ATGCTTCCTGACGTCTACAAGTTTATCACAGTCTCGAGTGTCCTTTCCTTGTTGTTGACATTCTTATTTCAAATTGACTGCATGATAAGGGCACACC GAGAGGCGAAGGTTGCTGCACAGTTGCAGAAAGAGAGCGAGTGGGACAATATCATCAATAGAACTTTCCAGTATTCTAAGCTTGAAAATCCTATTGG СTATCGCTCTACAGCGGAGGAAAGACTCCAATCAGAACACCCCGAGGCTTTCGAGTACTACAAGTTTTGCATTGGAAAGGAAGACCTCGTTGAACAG GCAAAACAACCGGAGATAGCATACTTTGAAAAGATTATAGCTTTCATCACACTTGTATTAATGGCTTTTGACGCTGAGCGGAGTGATGGAGTGTTCA AGATACTCAATAAGTTCAAAGGAATACTGAGCTCAACGGAGAGGGAGATCATCTACACGCAGAGTTTGGATGATTACGTTACAACCTTTGATGACAA TATGACAATCAACCTCGAGTTGAATATGGATGAACTCCACAAGACGAGCCTTCCTGGAGTCACTTTTAAGCAATGGTGGAACAACCAAATCAGCCGA GGCAACGTGAAGCCACATTATAGAACTGAGGGGCACTTCATGGAGTTTACCAGAGATACTGCGGCATCGGTTGCCAGCGAGATATCACACTCACCCG CAAGAGATTTTCTTGTGAGAGGTGCTGTTGGATCTGGAAAATCCACAGGACTTCCATACCATTTATCAAAGAGAGGGAGAGTGTTAATGCTTGAGCC TACCAGACCACTCACAGATAACGTGCACAAGCAACTGAGAAGTGAACCATTTAACTGCTTCCCAACTTTGAGGATGAGAGGGAAGTCAACTTTTGGG TCATCACCGATTACAGTCATGACTAGTGGATTCGCTTTACACCATTTTGCACGAAACATAGCTGAGGTAAAAACATACGATTTTGTCATAATTGATG AATGTCATGTGAATGATGCTTCTGCTATAGCGTTTAGGAATCTACTGTTTGAACATGAATTTGAAGGAAAAGTCCTCAAAGTGTCAGCCACACCACC AGGTAGAGAAGTTGAATTCACAACTCAGTTTCCCGTGAAACTCAAGATAGAAGAGGCTCTTAGCTTTCAGGAATTTGTAAGTTTACAAGGGACAGGT GCCAACGCCGATGTGATTAGTTGTGGCGACAACATACTAGTATATGTTGCTAGCTACAATGATGTTGATAGTCTTGGCAAGCTCCTTGTGCAAAAGG GATACAAAGTGTCGAAGATTGATGGAAGAACAATGAAGAGTGGAGGAACTGAAATAATCACTGAAGGTACTTCAGTGAAAAAGCATTTCATAGTCGC AACTAATATTATTGAGAATGGTGTAACCATTGACATTGATGTAGTTGTGGATTTTGGGACTAAGGTTGTACCAGTTTTGGATGTGGACAATAGAGCG GTGCAGTACAACAAAACTGTGGTGAGTTATGGGGAGCGCATCCAAAGACTCGGTAGAGTTGGGCGACACAAGGAAGGAGTAGCACTTCGAATTGGCC AAACAAATAAAACACTGGTTGAAATTCCAGAAATGGTTGCCACTGAAGCTGCCTTTCTATGCTTCATGTACAATTTGCCAGTGACAACACAGAGTGT TTCAACCACACTGCTGGAAAATGCCACATTATTACAAGCTAGAACTATGGCACAGTTTGAGCTATCATATTTTTACACAATTAATTTTGTGCGATTT GATGGTAGTATGCATCCAGTCATACATGACAAGCTGAAGCGCTTTAAGCTACACACTTGTGAGACATTCCTCAATAAGTTGGCGATCCCAAATAAAG GCTTATCCTCTTGGCTTACGAGTGGAGAGTATAAGCGACTTGGTTACATAGCAGAGGATGCTGGCATAAGAATCCCATTCGTGTGCAAAGAAATTCC AGACTCCTTGCATGAGGAAATTTGGCACATTGTAGTCGCCCATAAAGGTGACTCGGGTATTGGGAGGCTCACTAGCGTACAGGCAGCAAAGGTTGTT TATACTCTGCAAACGGATGTGCACTCAATTGCGAGGACTCTAGCATGCATCAATAGACTCATAGCACATGAACAAATGAAGCAGAGTCATTTTGAAG CCGCAACTGGGAGAGCATTTTCCTTCACAAATTACTCAATACAAAGCATATTTGACACGCTGAAAGCAAATTATGCTACAAAGCATACGAAAGAAAA TATTGCAGTGCTTCAGCAGGCAAAAGATCAATTGCTAGAGTTTTCGAACCTAGCAAAGGATCAAGATGTCACGGGTATCATCCAAGACTTCAATCAC CTGGAAACTATCTATCTCCAATCAGATAGCGAAGTGGCTAAGCATCTGAAGCTTAAAAGTCACTGGAATAAAAGCCAAATCACTAGGGACATCATAA TAGCTTTGTCTGTGTTAATTGGTGGTGGATGGATGCTTGCAACGTACTTCAAGGACAAGTTCAATGAACCAGTCTATTTCCAAGGGAAGAAGAATCA GAAGCACAAGCTTAAGATGAGAGAGGCGCGTGGGGCTAGAGGGCAATATGAGGTTGCAGCGGAGCCAGAGGCGCTAGAACATTACTTTGGAAGCGCA TATAATAACAAAGGAAAGCGCAAGGGCACCACGAGAGGAATGGGTGCAAAGTCTCGGAAATTCATAAACATGTATGGGTTTGATCCAACTGATTTTT CATACATTAGGTTTGTGGATCCATTGACAGGTCACACTATTGATGAGTCCACAAACGCACCTATTGATTTAGTGCAGCATGAGTTTGGAAAGTTAG AACACGCATGTTAATTGACGATGAGATAGAGCCTCAAAGTCTTAGCACCCACACCACAATCCATGCTTATTTGGTGAATAGTGGCACGAAGAAAGTT 
CTTAAGGTTGATTTAACACCACACTCGTCGCTACGTGCGAGTGAGAAATCAACAGCAATAATGGGATTTCCTGAAAGGGAGAATGAATTGCGTCAAA CCGGCATGGCAGTGCCAGTGGCTTATGATCAATTGCCACCAAAGAGTGAGGACTTGACGTTTGAAGGAGAAAGCTTGTTTAAGGGACCACGTGATTA CAACCCGATATCGAGCACCATTTGTCACTTGACGAATGAATCTGATGGGCACACAACATCGTTGTATGGTATTGGATTTGGTCCCTTCATCATTACA AACAAGCACTTGTTTAGAAGAAATAATGGAACACTGTTGGTCCAATCACTACATGGTGTATTCAAGGTCAAGAACACCACGACTTTGCAACAACACC TCATTGATGGGAGGGACATGATAATTATTCGCATGCCTAAGGATTTCCCACCATTTCCTCAAAAGCTGAAATTTAGAGAGCCACAAAGGGAAGAGCG CATATGTCTTGTGACAACCAACTTCCAAACTAAGAGCATGTCTAGCATGGTGTCAGACACTAGTTGCACATTCCCTTCATCTGATGGCATATTCTGG AAGCATTGGATTCAAACCAAGGATGGGCAGTGTGGCAGTCCATTAGTATCAACTAGAGATGGGTTCATTGTTGGTATACACTCAGCATCGAATTTCA CCAACACAAACAATTATTTCACAAGCGTGCCGAAAAACTTCATGGAATTGTTGACAAATCAGGAGGCGCAGCAGTGGGTTAGTGGTTGGCGATTAAA TGCTGACTCAGTATTGTGGGGGGGCCATAAAGTTTTCATGAGCAAACCTGAAGAGCCTTTTCAGCCAGTTAAGGAAGCGACTCAACTCATGAGTGAA TTGGTGTACTCGCAAGGGGAGAAGAGGAAATGGGTCGTGGAAGCACTGTCAGGGAACTTGAGGCCAGTGGCTGAGTGTCCCAGTCAGTTAGTCACAA AGCATGTGGTTAAAGGAAAGTGTCCCCTCTTTGAGCTCTACTTGCAGTTGAATCCAGAAAAGGAAGCATATTTTAAACCGATGATGGGAGCATATAA GCCAAGTCGACTTAATAGAGAGGCGTTCCTCAAGGACATTCTAAAATATGCTAGTGAAATTGAGATTGGGAATGTGGATTGTGACTTGCTGGAGCTT GCAATAAGCATGCTCATCACAAAGCTCAAGGCGTTAGGATTCCCAACTGTGAACTACATCACTGACCCAGAGGAAATTTTTAGTGCATTGAATATGA AAGCAGCTATGGGAGCACTATACAAAGGCAAGAAGAAAGAAGCTCTCAGCGAGCTCACACTAGATGAGCAGGAGGCAATGCTCAAAGCAAGTTGCCT GCGACTGTATACGGGAAAGCTGGGAATTTGGAATGGCTCATTGAAAGCAGAGTTGCGTCCAATTGAGAAGGTTGAAAACAACAAAACGCGAACTTTC ACAGCAGCACCAATAGACACTCTTCTTGCTGGTAAAGTTTGCGTGGATGATTTCAACAATCAATTTTATGATCTCAACATAAAGGCACCATGGACAG TTGGTATGACTAAGTTTTATCAGGGGTGGAATGAATTGATGGAGGCTTTACCAAGTGGGTGGGTGTATTGTGACGCTGATGGTTCGCAATTCGACAG TTCCTTGACTCCATTCCTCATTAATGCTGTATTGAAAGTGCGACTTGCCTTCATGGAGGAATGGGATATTGGTGAGCAAATGCTGCGAAATTTGTAC ACTGAGATAGTGTATACACCAATCCTCACACCGGATGGTACTATCATTAAGAAGCATAAAGGCAACAATAGCGGGCAACCTTCAACAGTGGTGGACA ACACACTCATGGTCATTATTGCAATGTTATACACATGTGAGAAGTGTGGAATCAACAAGGAAGAGATTGTGTATTACGTCAATGGCGATGACCTATT GATTGCCATTCACCCAGATAAAGCTGAGAGGTTGAGTGGATTCAAAGAATCTTTCGGAGAGTTGGGCCTGAAATATGAATTTGACTGCACCACCAGG GACAAGACACAGTTGTGGTTCATGTCACACAGGGCTTTGGAGAGGGATGGCATGTATATACCAAAGCTAGAAGAAGAAAGGATTGTTTCTATTTTGG AATGGGACAGATCCAAAGAGCCGTCACATAGGCTTGAAGCCATCTGTGCATCAATGATCGAAGCATGGGGTTATGACAAGCTGGTTGAAGAAATCCG CAATTTCTATGCATGGGTTTTGGAACAAGCGCCGTATTCACAGCTTGCAGAAGAAGGAAAGGCGCCATATCTGGCTGAGACTGCGCTTAAGTTTTTG TACACATCTCAGCACGGAACAAACTCTGAGATAGAAGAGTATTTAAAAGTGTTGTATGATTACGATATTCCAACGACTGAGAATCTTTATTTTCAGA GTGGCACTGTGGGTGCTGGTGTTGACGCTGGTAAGAAGAAAGATCAAAAGGATGATAAAGTCGCTGAGCAGGCTTCAAAGGATAGGGATGTTAATGC TGGAACTTCAGGAACATTCTCAGTTCCACGAATAAATGCTATGGCCACAAAACTTCAATATCCAAGGATGAGGGGAGAGGTGGTTGTAAACTTGAAT CACCTTTTAGGATACAAGCCACAGCAAATTGATTTGTCAAATGCTCGAGCCACACATGAGCAGTTTGCCGCGTGGCATCAGGCAGTGATGACAGCCT ATGGAGTGAATGAAGAGCAAATGAAAATATTGCTAAATGGATTTATGGTGTGGTGCATAGAAAATGGGACTTCCCCAAATTTGAACGGAACTTGGGT TATGATGGATGGTGAGGAGCAAGTTTCATACCCGCTGAAACCAATGGTTGAAAACGCGCAGCCAACACTGAGGCAAATTATGACACACTTCAGTGAC CTGGCTGAAGCGTATATTGAGATGAGGAATAGGGAGCGACCATACATGCCTAGGTATGGTCTACAGAGAAACATTACAGACATGAGTTTGTCACGCT ATGCGTTCGACTTCTATGAGCTAACTTCAAAAACACCTGTTAGAGCGAGGGAGGCGCATATGCAAATGAAAGCTGCTGCAGTACGAAACAGTGGAAC TAGGTTATTTGGTCTTGATGGCAACGTGGGTACTGCAGAGGAAGACACTGAACGGCACACAGCGCACGATGTGAACCGTAACATGCACACACTATTA GGGGTCCGCCAGTGATAGTTTCTGCGTGTCTTTGCTTTCCGCTTTTAAGCTTATTGTAATATATATGAATAGCTATTCACAGTGGGACTTGGTCTTG TGTTGAATGGTATCTTATATGTTTTAATATGTCTTATTAGTCTCATTACTTAGGCGAACGACAAAGTGAGGTCACCTCGGTCTAATTCTCCTATGTA GTGCGAGAAAAAAAAAAAAAAAAAAAAAAAAAAAAAAAAAAAAAAAAAAAAAGATCTGCGTTGCTGGCGTTTTTCCATAGGCTCCGCCCCCCTGACG AGCATCACAAAAATCGACGCTCAAGTCAGAGGTGGCGAAACCCGACAGGACTATAAAGATACCAGGCGTTTCCCCCTGGAAGCTCCCTCGTGCGCTC TCCTGTTCCGACCCTGCCGCTTACCGGATACCTGTCCGCCTTTCTCCCTTCGGGAAGCGTGGCGCTTTCTCATAGCTCACGCTGTAGGTATCTCAGT TCGGTGTAGGTCGTTCGCTCCAAGCTGGGCTGTGTGCACGAACCCCCCGTTCAGCCCGACCGCTGCGCCTTATCCGGTAACTATCGTCTTGAGTCCA ACCCGGTAAGACACGACTTATCGCCACTGGCAGCAGCCACTGGTAACAGGATTAGCAGAGCGAGGTATGTAGGCGGTGCTACAGAGTTCTTGAAGTG GTGGCCTAACTACGGCTACACTAGAAGGACAGTATTTGGTATCTGCGCTCTGCTGAAGCCAGTTACCTTCGGAAAAAGAGTTGGTAGCTCTTGATCC GGCAAACAAACCACCGCTGGTAGCGGTGGTTTTTTTGTTTGCAAGCAGCAGATTACGCGCAGAAAAAAAGGATCTCAAGAAGATCCTTTGATCTTTT CTACGGGGTCTGACGCTCAGTGGAACGAAAACTCACGTTAAGGGATTTTGGTCATGAGATTATCAAAAAGGATCTTCACCTAGATCCTTTTAAATTA AAAATGAAGTTTTAAATCAATCTAAAGTATATATGAGTAAACTTGGTCTGACAGTTACCAATGCTTAATCAGTGAGGCACCTATCTCAGCGATCTGT CTATTTCGTTCATCCATAGTTGCCTGACTCCCCGTCGTGTAGATAACTACGATACGGGAGGGCTTACCATCTGGCCCCAGTGCTGCAATGATACCGC GAGACCCACGCTCACCGGCTCCAGATTTATCAGCAATAAACCAGCCAGCCGGAAGGGCCGAGCGCAGAAGTGGTCCTGCAACTTTATCCGCCTCCAT CCAGTCTATTAATTGTTGCCGGGAAGTAGAGTAAGTAGTTCGCCAGTTAATAGTTTGCGCAACGTTGTTGCCATTGCTACAGGCATCGTGGTGTCA CGCTCGTCGTTTGGTATGGCTTCATTCAGCTCCGGTTCCCAACGATCAAGGCGAGTTACATGATCCCCCATGTTGTGCAAAAAAGCGGTTAGCTCCT TCGGTCCTCCGATCGTTGTCAGAAGTAAGTTGGCCGCAGTGTTATCACTCATGGTTATGGCAGCACTGCATAATTCTCTTACTGTCATGCCATCCGT AAGATGCTTTTCTGTGACTGGTGAGTACTCAACCAAGTCATTCTGAGAATAGTGTATGCGGCGACCGAGTTGCTCTTGCCCGGCGTCAATACGGGAT AATACCGCGCCACATAGCAGAACTTTAAAAGTGCTCATCATTGGAAAACGTTCTTCGGGGCGAAAACTCTCAAGGATCTTACCGCTGTTGAGATCCA GTTCGATGTAACCCACTCGTGCACCCAACTGATCTTCAGCATCTTTTACTTTCACCAGCGTTTCTGGGTGAGCAAAAACAGGAAGGCAAAATGCCGC AAAAAAGGGAATAAGGGCGACACGGAAATGTTGAATACTCATACTCTTCCTTTTTCAATATTATTGAAGCATTTATCAGGGTTATTGTCTCATCCCG GG 
Fig. 2 supplementary. Sequence of expression vector p35TEV $(11,762 \mathrm{bp})$ which contains an infectious TEV cDNA clone (Genebank access no. DQ986288). The sequences corresponding to the CaMV 35 S promoter (blue, transcription +1 nucleotide underlined), the $35 S$ terminator (blue, processing and polyadenylation site underlined), the minimal pUC replication origin (light gray), the $\beta$-lactamase open reading frame (dark gray, complementary sequence) and the unique restriction sites Paul, Bglll, Apal, Xmal and Notl (green) are marked.

GATTCCATTGCCCAGCTATCTGTCACTTTATTGTGAAGATAGTGGAAAAGGAAGTGGCTCCTACAAATGCCATCATTGCGATAAAGGAAAGGCCAT CGTTGAAGATGCCTCTGCCGACAGTGGTCCCAAAGATGGACCCCCACCCACGAGGAGCATCGTGGAAAAAGAAGACGTTCCAACCACGTCTTCAAAG CAAGTGGATTGATGTGATATCTCCACTGACGTAAGGGATGACGCACAATCCCACTATCCTTCGCAAGACCCTTCCTCTATATAAGGAAGTTCATTTC ATTTGGAGAGGAAAATAACAAATCTCAACACAACATATACAAAACAAACGAATCTCAAGCAATCAAGCATTCTACTTCTATTGCAGCAATTTAAATC ATTTCTTTTAÄAGCAAAAGCAATTTTCTGAAAATTTTCACCATTTACGAACGATAGCCATGGCACTCATCTTTGGCACAGTCAACGCTAACATCCTG AAGGAAGTGTTCGGTGGAGCTCGTATGGCTTGCGTTACCAGCGCACATATGGCTGGAGCGAATGGAAGCATTTTGAAGAAGGCAGAAGAGACCTCTC GTGCAATCATGCACAAACCAGTGATCTTCGGAGAAGACTACATTACCGAGGCAGACTTGCCTTACACACCACTCCATTTAGAGGTCGATGCTGAAAT GGAGCGGATGTATTATCTTGGTCGTCGCGCGCTCACCCATGGCAAGAGACGCAAAGTTTCTGTGAATAACAAGAGGAACAGGAGAAGGAAAGTGGCC AAAACGTACGTGGGGCGTGATTCCATTGTTGAGAAGATTGTAGTGCCCCACACCGAGAGAAAGGTTGATACCACAGCAGCAGTGGAAGACATTTGCA ATGAAGCTACCACTCAACTTGTGCATAATAGTATGCCAAAGCGTAAGAAGCAGAAAAACTTCTTGCCCGCCACTTCACTAAGTAACGTGTATGCCCA AACTTGGAGCATAGTGCGCAAACGCCATATGCAGGTGGAGATCATTAGCAAGAAGAGCGTCCGAGCGAGGGTCAAGAGATTTGAGGGCTCGGTGCAA TTGTTCGCAAGTGTGCGTCACATGTATGGCGAGAGGAAAAGGGTGGACTTACGTATTGACAACTGGCAGCAAGAGACACTTCTAGACCTTGCTAAAA GATTTAAGAATGAGAGAGTGGATCAATCGAAGCTCACTTTTGGTTCAAGTGGCCTAGTTTTGAGGCAAGGCTCGTACGGACCTGCGCATTGGTATCG ACATGGTATGTTCATTGTACGCGGTCGGTCGGATGGGATGTTGGTGGATGCTCGTGCGAAGGTAACGTTCGCTGTTTGTCACTCAATGACACATTAT AGCGACAAATCAATCTCTGAGGCATTCTTCATACCATACTCTAAGAAATTCTTGGAGTTGAGACCAGATGGAATCTCCCATGAGTGTACAAGAGGAG TATCAGTTGAGCGGTGCGGTGAGGTGGCTGCAATCCTGACACAAGCACTTTCACCGTGTGGTAAGATCACATGCAAACGTTGCATGGTTGAAACACC TGACATTGTTGAGGGTGAGTCGGGAGACAGTGTCACCAACCAAGGTAAGCTCCTAGCAATGCTGAAAGAACAGTATCCAGATTTCCCAATGGCCGAG AAACTACTCACAAGGTTTTTGCAACAGAAATCACTAGTAAATACAAATTTGACAGCCTGCGTGAGCGTCAAACAACTCATTGGTGACCGCAAACAAG CTCCATTCACACACGTACTGGCTGTCAGCGAAATTCTGTTTAAAGGCAATAAACTAACAGGGGCCGATCTCGAAGAGGCAAGCACACATATGCTTGA AATAGCAAGGTTCTTGAACAATCGCACTGAAAATATGCGCATTGGCCACCTTGGTTCTTTCAGAAATAAAATCTCATCGAAGGCCCATGTGAATAAC GCACTCATGTGTGATAATCAACTTGATCAGAATGGGAATTTTATTTGGGGACTAAGGGGTGCACACGCAAAGAGGTTTCTTAAAGGATTTTTCACTG AGATTGACCCAAATGAAGGATACGATAAGTATGTTATCAGGAAACATATCAGGGGTAGCAGAAAGCTAGCAATTGGCAATTTGATAATGTCAACTGA CTTCCAGACGCTCAGGCAACAAATTCAAGGCGAAACTATTGAGCGTAAAGAAATTGGGAATCACTGCATTTCAATGCGGAATGGTAATTACGTGTAC CCATGTTGTTGTGTTACTCTTGAAGATGGTAAGGCTCAATATTCGGATCTAAAGCATCCAACGAAGAGACATCTGGTCATTGGCAACTCTGGCGATT CAAAGTACCTAGACCTTCCAGTTCTCAATGAAGAGAAAATGTATATAGCTAATGAAGGTTATTGCTACATGAACATTTTCTTTGCTCTACTAGTGAA TGTCAAGGAAGAGGATGCAAAGGACTTCACCAAGTTTATAAGGGACACAATTGTTCCAAAGCTTGGAGCGTGGCCAACAATGCAAGATGTTGCAACT GCATGCTACTTACTTTCCATTCTTTACCCAGATGTCCTGAGTGCTGAATTACCCAGAATTTTGGTTGATCATGACAACAAAACAATGCATGTTTTGG ATTCGTATGGGTCTAGAACGACAGGATACCACATGTTGAAAATGAACACAACATCCCAGCTAATTGAATTCGTTCATTCAGGTTTGGAATCCGAAAT GAAAACTTACAATGTTGGAGGGATGAACCGAGATATGGTCACACAAGGTGCAATTGAGATGTTGATCAAGTCCATATACAAACCACATCTCATGAAG CAGTTACTTGAGGAGGAGCCATACATAATTGTCCTGGCAATAGTCTCCCCTTCAATTTTAATTGCCATGTACAACTCTGGAACTTTTGAGCAGGCGT TACAAATGTGGTTGCCAAATACAATGAGGTTAGCTAACCTCGCTGCCATCTTGTCAGCCTTGGCGCAAAAGTTAACTTTGGCAGACTTGTTCGTCCA GCAGCGTAATTTGATTAATGAGTATGCGCAGGTAATTTTGGACAATCTGATTGACGGTGTCAGGGTTAACCATTCGCTATCCCTAGCAATGGAAATT GTTACTATTAAGCTGGCCACCCAAGAGATGGACATGGCGTTGAGGGAAGGTGGCTATGCTGTGACCTCTGAAAAGGTGCATGAAATGTTGGAAAAAA ACTATGTAAAGGCTTTGAAGGATGCATGGGACGAATTAACTTGGTTGGAAAAATTCTCCGCAATCAGGCATTCAAGAAAGCTCTTGAAATTTGGGCG AAAGCCTTTAATCATGAAAAACACCGTAGATTGCGGCGGACATATAGACTTGTCTGTGAAATCGCTTTTCAAGTTCCACTTGGAACTCCTGAAGGGA ACCATCTCAAGAGCCGTAAATGGTGGTGCAAGAAAGGTAAGAGTAGCGAAGAATGCCATGACAAAAGGGGTTTTTCTCAAAATCTACAGCATGCTTC CTGACGTCTACAAGTTTATCACAGTCTCGAGTGTCCTTTCCTTGTTGTTGACATTCTTATTTCAAATTGACTGCATGATAAGGGCACACCGAGAGGC GAAGGTTGCTGCACAGTTGCAGAAAGAGAGCGAGTGGGACAATATCATCAATAGAACTTTCCAGTATTCTAAGCTTGAAAATCCTATTGGCTATCGC TCTACAGCGGAGGAAAGACTCCAATCAGAACACCCCGAGGCTTTCGAGTACTACAAGTTTTGCATTGGAAAGGAAGACCTCGTTGAACAGGCAAAAC AACCGGAGATAGCATACTTTGAAAAGATTATAGCTTTCATCACACTTGTATTAATGGCTTTTGACGCTGAGCGGAGTGATGGAGTGTTCAAGATACT CAATAAGTTCAAAGGAATACTGAGCTCAACGGAGAGGGAGATCATCTACACGCAGAGTTTGGATGATTACGTTACAACCTTTGATGACAATATGACA ATCAACCTCGAGTTGAATATGGATGAACTCCACAAGACGAGCCTTCCTGGAGTCACTTTTAAGCAATGGTGGAACAACCAAATCAGCCGAGGCAACG TGAAGCCACATTATAGAACTGAGGGGCACTTCATGGAGTTTACCAGAGATACTGCGGCATCGGTTGCCAGCGAGATATCACACTCACCCGCAAGAGA TTTTCTTGTGAGAGGTGCTGTTGGATCTGGAAAATCCACAGGACTTCCATACCATTTATCAAAGAGAGGGAGAGTGTTAATGCTTGAGCCTACCAGA CCACTCACAGATAACGTGCACAAGCAACTGAGAAGTGAACCATTTAACTGCTTCCCAACTTTGAGGATGAGAGGGAAGTCAACTTTTGGGTCATCAC CGATTACAGTCATGACTAGTGGATTCGCTTTACACCATTTTGCACGAAACATAGCTGAGGTAAAAACATACGATTTTGTCATAATTGATGAATGTCA TGTGAATGATGCTTCTGCTATAGCGTTTAGGAATCTACTGTTTGAACATGAATTTGAAGGAAAAGTCCTCAAAGTGTCAGCCACACCACCAGGTAGA GAAGTTGAATTCACAACTCAGTTTCCCGTGAAACTCAAGATAGAAGAGGCTCTTAGCTTTCAGGAATTTGTAAGTTTACAAGGGACAGGTGCCAACG CCGATGTGATTAGTTGTGGCGACAACATACTAGTATATGTTGCTAGCTACAATGATGTTGATAGTCTTGGCAAGCTCCTTGTGCAAAAGGGATACAA AGTGTCGAAGATTGATGGAAGAACAATGAAGAGTGGAGGAACTGAAATAATCACTGAAGGTACTTCAGTGAAAAAGCATTTCATAGTCGCAACTAAT ATTATTGAGAATGGTGTAACCATTGACATTGATGTAGTTGTGGATTTTGGGACTAAGGTTGTACCAGTTTTGGATGTGGACAATAGAGCGGTGCAGT ACAACAAAACTGTGGTGAGTTATGGGGAGCGCATCCAAAGACTCGGTAGAGTTGGGCGACACAAGGAAGGAGTAGCACTTCGAATTGGCCAAACAAA TAAAACACTGGTTGAAATTCCAGAAATGGTTGCCACTGAAGCTGCCTTTCTATGCTTCATGTACAATTTGCCAGTGACAACACAGAGTGTTTCAACC ACACTGCTGGAAAATGCCACATTATTACAAGCTAGAACTATGGCACAGTTTGAGCTATCATATTTTTACACAATTAATTTTGTGCGATTTGATGGTA GTATGCATCCAGTCATACATGACAAGCTGAAGCGCTTTAAGCTACACACTTGTGAGACATTCCTCAATAAGTTGGCGATCCCAAATAAAGGCTTATC СTCTTGGCTTACGAGTGGAGAGTATAAGCGACTTGGTTACATAGCAGAGGATGCTGGCATAAGAATCCCATTCGTGTGCAAAGAAATTCCAGACTCC TTGCATGAGGAAATTTGGCACATTGTAGTCGCCCATAAAGGTGACTCGGGTATTGGGAGGCTCACTAGCGTACAGGCAGCAAAGGTTGTTTATACTC TGCAAACGGATGTGCACTCAATTGCGAGGACTCTAGCATGCATCAATAGACTCATAGCACATGAACAAATGAAGCAGAGTCATTTTGAAGCCGCAAC TGGGAGAGCATTTTCCTTCACAAATTACTCAATACAAAGCATATTTGACACGCTGAAAGCAAATTATGCTACAAAGCATACGAAAGAAAATATTGCA GTGCTTCAGCAGGCAAAAGATCAATTGCTAGAGTTTTCGAACCTAGCAAAGGATCAAGATGTCACGGGTATCATCCAAGACTTCAATCACCTGGAAA СTATCTATCTCCAATCAGATAGCGAAGTGGCTAAGCATCTGAAGCTTAAAAGTCACTGGAATAAAAGCCAAATCACTAGGGACATCATAATAGCTTT GTCTGTGTTAATTGGTGGTGGATGGATGCTTGCAACGTACTTCAAGGACAAGTTCAATGAACCAGTCTATTTCCAAGGGAAGAAGAATCAGAAGCAC AAGCTTAAGATGAGAGAGGCGCGTGGGGCTAGAGGGCAATATGAGGTTGCAGCGGAGCCAGAGGCGCTAGAACATTACTTTGGAAGCGCATATAATA ACAAAGGAAAGCGCAAGGGCACCACGAGAGGAATGGGTGCAAAGTCTCGGAAATTCATAAACATGTATGGGTTTGATCCAACTGATTTTTCATACAT TAGGTTTGTGGATCCATTGACAGGTCACACTATTGATGAGTCCACAAACGCACCTATTGATTTAGTGCAGCATGAGTTTGGAAAGGTTAGAACACGC ATGTTAATTGACGATGAGATAGAGCCTCAAAGTCTTAGCACCCACACCACAATCCATGCTTATTTGGTGAATAGTGGCACGAAGAAAGTTCTTAAGG 
TTGATTTAACACCACACTCGTCGCTACGTGCGAGTGAGAAATCAACAGCAATAATGGGATTTCCTGAAAGGGAGAATGAATTGCGTCAAACCGGCAT GGCAGTGCCAGTGGCTTATGATCAATTGCCACCAAAGAGTGAGGACTTGACGTTTGAAGGAGAAAGCTTGTTTAAGGGACCACGTGATTACAACCCG ATATCGAGCACCATTTGTCACTTGACGAATGAATCTGATGGGCACACAACATCGTTGTATGGTATTGGATTTGGTCCCTTCATCATTACAAACAAGC ACTTGTTTAGAAGAAATAATGGAACACTGTTGGTCCAATCACTACATGGTGTATTCAAGGTCAAGAACACCACGACTTTGCAACAACACCTCATTGA TGGGAGGGACATGATAATTATTCGCATGCCTAAGGATTTCCCACCATTTCCTCAAAAGCTGAAATTTAGAGAGCCACAAAGGGAAGAGCGCATATGT СTTGTGACAACCAACTTCCAAACTAAGAGCATGTCTAGCATGGTGTCAGACACTAGTTGCACATTCCCTTCATCTGATGGCATATTCTGGAAGCATT GGATTCAAACCAAGGATGGGCAGTGTGGCAGTCCATTAGTATCAACTAGAGATGGGTTCATTGTTGGTATACACTCAGCATCGAATTTCACCAACAC AAACAATTATTTCACAAGCGTGCCGAAAAACTTCATGGAATTGTTGACAAATCAGGAGGCGCAGCAGTGGGTTAGTGGTTGGCGATTAAATGCTGAC TCAGTATTGTGGGGGGGCCATAAAGTTTTCATGAGCAAACCTGAAGAGCCTTTTCAGCCAGTTAAGGAAGCGACTCAACTCATGAGTGAATTGGTGT ACTCGCAAGGGGAGAAGAGGAAATGGGTCGTGGAAGCACTGTCAGGGAACTTGAGGCCAGTGGCTGAGTGTCCCAGTCAGTTAGTCACAAAGCATGT GGTTAAAGGAAAGTGTCCCCTCTTTGAGCTCTACTTGCAGTTGAATCCAGAAAAGGAAGCATATTTTAAACCGATGATGGGAGCATATAAGCCAAGT CGACTTAATAGAGAGGCGTTCCTCAAGGACATTCTAAAATATGCTAGTGAAATTGAGATTGGGAATGTGGATTGTGACTTGCTGGAGCTTGCAATAA GCATGCTCATCACAAAGCTCAAGGCGTTAGGATTCCCAACTGTGAACTACATCACTGACCCAGAGGAAATTTTTIAGTGCATTGAATATGAAAGCAGC TATGGGAGCACTATACAAAGGCAAGAAGAAAGAAGCTCTCAGCGAGCTCACACTAGATGAGCAGGAGGCAATGCTCAAAGCAAGTTGCCTGCGACTG TATACGGGAAAGCTGGGAATTTGGAATGGCTCATTGAAAGCAGAGTTGCGTCCAATTGAGAAGGTTGAAAACAACAAAACGCGAACTTTCACAGCAG CACCAATAGACACTCTTCTTGCTGGTAAAGTTTGCGTGGATGATTTCAACAATCAATTTTATGATCTCAACATAAAGGCACCATGGACAGTTGGTAT GACTAAGTTTTATCAGGGGTGGAATGAATTGATGGAGGCTTTACCAAGTGGGTGGGTGTATTGTGACGCTGATGGTTCGCAATTCGACAGTTCCTTG ACTCCATTCCTCATTAATGCTGTATTGAAAGTGCGACTTGCCTTCATGGAGGAATGGGATATTGGTGAGCAAATGCTGCGAAATTTGTACACTGAGA TAGTGTATACACCAATCCTCACACCGGATGGTACTATCATTAAGAAGCATAAAGGCAACAATAGCGGGCAACCTTCAACAGTGGTGGACAACACACT CATGGTCATTATTGCAATGTTATACACATGTGAGAAGTGTGGAATCAACAAGGAAGAGATTGTGTATTACGTCAATGGCGATGACCTATTGATTGCC ATTCACCCAGATAAAGCTGAGAGGTTGAGTGGATTCAAAGAATCTTTCGGAGAGTTGGGCCTGAAATATGAATTTGACTGCACCACCAGGGACAAGA CACAGTTGTGGTTCATGTCACACAGGGCTTTGGAGAGGGATGGCATGTATATACCAAAGCTAGAAGAAGAAAGGATTGTTTCTATTTTGGAATGGGA CAGATCCAAAGAGCCGTCACATAGGCTTGAAGCCATCTGTGCATCAATGATCGAAGCATGGGGTTATGACAAGCTGGTTGAAGAAATCCGCAATTTC TATGCATGGGTTTTGGAACAAGCGCCGTATTCACAGCTTGCAGAAGAAGGAAAGGCGCCATATCTGGCTGAGACTGCGCTTAAGTTTTTGTACACAT CTCAGCACGGAACAAACTCTGAGATAGAAGAGTATTTAAAAGTGTTGTATGATTACGATATTCCAACGACTGAGAATCTTTATTTTCAGAGTGGCAC TGTGGGTGCTGGTGTTGACGCTGGTAAGAAGAAAGATCAAAAGGATGATAAAGTCGCTGAGCAGGCTTCAAAGGATAGGGATGTTAATGCTGGAACT TCAGGAACATTCTCAGTTCCACGAATAAATGCTATGGCCACAAAACTTCAATATCCAAGGATGAGGGGAGAGGTGGTTGTAAACTTGAATCACCTTT TAGGATACAAGCCACAGCAAATTGATTTGTCAAATGCTCGAGCCACACATGAGCAGTTTGCCGCGTGGCATCAGGCAGTGATGACAGCCTATGGAGT GAATGAAGAGCAAATGAAAATATTGCTAAATGGATTTATGGTGTGGTGCATAGAAAATGGGACTTCCCCAAATTTGAACGGAACTTGGGTTATGATG GATGGTGAGGAGCAAGTTTCATACCCGCTGAAACCAATGGTTGAAAACGCGCAGCCAACACTGAGGCAAATTATGACACACTTCAGTGACCTGGCTG AAGCGTATATTGAGATGAGGAATAGGGAGCGACCATACATGCCTAGGTATGGTCTACAGAGAAACATTACAGACATGAGTTTGTCACGCTATGCGTT CGACTTCTATGAGCTAACTTCAAAAACACCTGTTAGAGCGAGGGAGGCGCATATGCAAATGAAAGCTGCTGCAGTACGAAACAGTGGAACTAGGTTA TTTGGTCTTGATGGCAACGTGGGTACTGCAGAGGAAGACACTGAACGGCACACAGCGCACGATGTGAACCGTAACATGCACACACTATTAGGGGTCC GCCAGTGATAGTTTCTGCGTGTCTTTGCTTTCCGCTTTTAAGCTTATTGTAATATATATGAATAGCTATTCACAGTGGGACTTGGTCTTGTGTTGAA TGGTATCTTATATGTTTTAATATGTCTTATTAGTCTCATTACTTAGGCGAACGACAAAGTGAGGTCACCTCGGTCTAATTCTCCTATGTAGTGCGAG AAAAAAAAAAAAAAAAAAAAAAAAAAAAAAAAAAAAAAAAAAAAAGATCTCGCTGAAATCACCAGTCTCTCTCTACAAATCTATCTCTCTCTATTTT CTCCATAAATAATGTGTGAGTAGTTTCCCGATAAGGGAAATTAGGGTTCTTATAGGGTTTCGCTCATGTGTTGAGCATATAAGAAACCCTTAGTATG TATTTGTATTTGTAAAATACTTCTATCAATAAAATTTCTAATTCCTAAAACCAAAATCCAGGGGCCCGGATCTGCGTTGCTGGCGTTTTTCCATAGG CTCCGCCCCCCTGACGAGCATCACAAAAATCGACGCTCAAGTCAGAGGTGGCGAAACCCGACAGGACTATAAAGATACCAGGCGTTTCCCCCTGGAA GCTCCCTCGTGCGCTCTCCTGTTCCGACCCTGCCGCTTACCGGATACCTGTCCGCCTTTCTCCCTTCGGGAAGCGTGGCGCTTTCTCATAGCTCACG СTGTAGGTATCTCAGTTCGGTGTAGGTCGTTCGCTCCAAGCTGGGCTGTGTGCACGAACCCCCCGTTCAGCCCGACCGCTGCGCCTTATCCGGTAAC TATCGTCTTGAGTCCAACCCGGTAAGACACGACTTATCGCCACTGGCAGCAGCCACTGGTAACAGGATTAGCAGAGCGAGGTATGTAGGCGGTGCTA CAGAGTTCTTGAAGTGGTGGCCTAACTACGGCTACACTAGAAGGACAGTATTTGGTATCTGCGCTCTGCTGAAGCCAGTTACCTTCGGAAAAAGAGT TGGTAGCTCTTGATCCGGCAAACAAACCACCGCTGGTAGCGGTGGTTTTTTTGTTTGCAAGCAGCAGATTACGCGCAGAAAAAAAGGATCTCAAGAA GATCCTTTGATCTTTTCTACGGGGTCTGACGCTCAGTGGAACGAAAACTCACGTTAAGGGATTTTGGTCATGAGATTATCAAAAAGGATCTTCACCT AGATCCTTTTAAATTAAAAATGAAGTTTTAAATCAATCTAAAGTATATATGAGTAAACTTGGTCTGACAGTTACCAATGCTTAATCAGTGAGGCACC TATCTCAGCGATCTGTCTATTTCGTTCATCCATAGTTGCCTGACTCCCCGTCGTGTAGATAACTACGATACGGGAGGGCTTACCATCTGGCCCCAG GCTGCAATGATACCGCGAGACCCACGCTCACCGGCTCCAGATTTATCAGCAATAAACCAGCCAGCCGGAAGGGCCGAGCGCAGAAGTGGTCCTGCA СTTTATCCGCCTCCATCCAGTCTATTAATTGTTGCCGGGAAGCTAGAGTAAGTAGTTCGCCAGTTAATAGTTTGCGCAACGTTGTTGCCATTGCTAC AGGCATCGTGGTGTCACGCTCGTCGTTTGGTATGGCTTCATTCAGCTCCGGTTCCCAACGATCAAGGCGAGTTACATGATCCCCCATGTTGTGCAAR AAAGCGGTTAGCTCCTTCGGTCCTCCGATCGTTGTCAGAAGTAAGTTGGCCGCAGTGTTATCACTCATGGTTATGGCAGCACTGCATAATTCTCTTI СTGTCATGCCATCCGTAAGATGCTTTTCTGTGACTGGTGAGTACTCAACCAAGTCATTCTGAGAATAGTGTATGCGGCGACCGAGTTGCTCTTGCCC GGCGTCAATACGGGATAATACCGCGCCACATAGCAGAACTTTAAAAGTGCTCATCATTGGAAAACGTTCTTCGGGGCGAAAACTCTCAAGGATCTTI ССGCTGTTGAGATCCAGTTCGATGTAACCCACTCGTGCACCCAACTGATCTTCAGCATCTTTTACTTTCACCAGCGTTTCTGGGTGAGCAAAAACAG GAAGGCAAAATGCCGCAAAAAAGGGATAAGGGCACACGGAAATGTTGAATACTCATACTCTTCCTTTTTCAATATTATTGAAGCATTTATCAGGG TTATTGTCTCATCCCGGGCGCCGC 
Fig. 3 supplementary. Sequence of binary plasmid pGTEV (12,753 bp) which contains an infectious TEV cDNA clone (Genebank access no. DQ986288). The sequences corresponding to the CaMV 35S promoter (blue, transcription +1 nucleotide underlined), the $35 \mathrm{~S}$ terminator (blue, processing and polyadenylation site underlined), the T-DNA right border and overdrive sequence (yellow, overdrive underlined), the T-DNA double left border (red), the minimal pUC replication origin (light gray), the kanamycin resistance open reading frame (dark gray, complementary sequence), the pSa replication origin and the unique restriction sites Paul, Bglll, Apal and Notl (green) are marked.

GATTCCATTGCCCAGCTATCTGTCACTTTATTGTGAAGATAGTGGAAAAGGAAGGTGGCTCCTACAAATGCCATCATTGCGATAAAGGAAAGGCCAT CGTTGAAGATGCCTCTGCCGACAGTGGTCCCAAAGATGGACCCCCACCCACGAGGAGCATCGTGGAAAAAGAAGACGTTCCAACCACGTCTTCAAAG CAAGTGGATTGATGTGATATCTCCACTGACGTAAGGGATGACGCACAATCCCACTATCCTTCGCAAGACCCTTCCTCTATATAAGGAAGTTCATTTC ATTTGGAGAGGAAATAACAAATCTCAACACAACATATACAAAACAAACGAATCTCAAGCAATCAAGCATTCTACTTCTATTGCAGCAATTTAAATC АTTTСTTTTAÄAGCAAAAGCAATTTTCTGAAAATTTTCACСАTTTACGAACGATAGCCATGGCACTCATCTTTGGCACAGTCAACGCTAACATCCTG AAGGAAGTGTTCGGTGGAGCTCGTATGGCTTGCGTTACCAGCGCACATATGGCTGGAGCGAATGGAAGCATTTTGAAGAAGGCAGAAGAGACCTCTC GTGCAATCATGCACAAACCAGTGATCTTCGGAGAAGACTACATTACCGAGGCAGACTTGCCTTACACACCACTCCATTTAGAGGTCGATGCTGAAAT GGAGCGGATGTATTATCTTGGTCGTCGCGCGCTCACCCATGGCAAGAGACGCAAAGTTTCTGTGAATAACAAGAGGAACAGGAGAAGGAAAGTGGCC AAAACGTACGTGGGGCGTGATTCCATTGTTGAGAAGATTGTAGTGCCCCACACCGAGAGAAAGGTTGATACCACAGCAGCAGTGGAAGACATTTGCA ATGAAGCTACCACTCAACTTGTGCATAATAGTATGCCAAAGCGTAAGAAGCAGAAAAACTTCTTGCCCGCCACTTCACTAAGTAACGTGTATGCCCA AACTTGGAGCATAGTGCGCAAACGCCATATGCAGGTGGAGATCATTAGCAAGAAGAGCGTCCGAGCGAGGGTCAAGAGATTTGAGGGCTCGGTGCAA TTGTTCGCAAGTGTGCGTCACATGTATGGCGAGAGGAAAAGGGTGGACTTACGTATTGACAACTGGCAGCAAGAGACACTTCTAGACCTTGCTAAAA GATTTAAGAATGAGAGAGTGGATCAATCGAAGCTCACTTTTGGTTCAAGTGGCCTAGTTTTGAGGCAAGGCTCGTACGGACCTGCGCATTGGTATCG ACATGGTATGTTCATTGTACGCGGTCGGTCGGATGGGATGTTGGTGGATGCTCGTGCGAAGGTAACGTTCGCTGTTTGTCACTCAATGACACATTAT AGCGACAAATCAATCTCTGAGGCATTCTTCATACCATACTCTAAGAAATTCTTGGAGTTGAGACCAGATGGAATCTCCCATGAGTGTACAAGAGGAG TATCAGTTGAGCGGTGCGGTGAGGTGGCTGCAATCCTGACACAAGCACTTTCACCGTGTGGTAAGATCACATGCAAACGTTGCATGGTTGAAACACC TGACATTGTTGAGGGTGAGTCGGGAGACAGTGTCACCAACCAAGGTAAGCTCCTAGCAATGCTGAAAGAACAGTATCCAGATTTCCCAATGGCCGAG AAACTACTCACAAGGTTTTTGCAACAGAAATCACTAGTAAATACAAATTTGACAGCCTGCGTGAGCGTCAAACAACTCATTGGTGACCGCAAACAAG СTCCATTCACACACGTACTGGCTGTCAGCGAAATTCTGTTTAAAGGCAATAAACTAACAGGGGCCGATCTCGAAGAGGCAAGCACACATATGCTTGA AATAGCAAGGTTCTTGAACAATCGCACTGAAAATATGCGCATTGGCCACCTTGGTTCTTTCAGAAATAAAATCTCATCGAAGGCCCATGTGAATAAC GCACTCATGTGTGATAATCAACTTGATCAGAATGGGAATTTTATTTGGGGACTAAGGGGTGCACACGCAAAGAGGTTTCTTAAAGGATTTTTCACTG AGATTGACCCAAATGAAGGATACGATAAGTATGTTATCAGGAAACATATCAGGGGTAGCAGAAAGCTAGCAATTGGCAATTTGATAATGTCAACTGA CTTCCAGACGCTCAGGCAACAAATTCAAGGCGAAACTATTGAGCGTAAAGAAATTGGGAATCACTGCATTTCAATGCGGAATGGTAATTACGTGTAC CСATGTTGTTGTGTTACTCTTGAAGATGGTAAGGCTCAATATTCGGATCTAAAGCATCCAACGAAGAGACATCTGGTCATTGGCAACTCTGGCGATT CAAAGTACСTAGACСTTCCAGTTCTCAATGAAGAGAAAATGTATATAGCTAATGAAGGTTATTGCTACATGAACATTTTCTTTGCTCTACTAGTGAA TGTCAAGGAAGAGGATGCAAAGGACTTCACCAAGTTTATAAGGGACACAATTGTTCCAAAGCTTGGAGCGTGGCCAACAATGCAAGATGTTGCAACT GCATGCTACTTACTTTCCATTCTTTACCCAGATGTCCTGAGTGCTGAATTACCCAGAATTTTGGTTGATCATGACAACAAAACAATGCATGTTTTGG ATTCGTATGGGTCTAGAACGACAGGATACCACATGTTGAAAATGAACACAACATCCCAGCTAATTGAATTCGTTCATTCAGGTTTGGAATCCGAAAT GAAAACTTACAATGTTGGAGGGATGAACCGAGATATGGTCACACAAGGTGCAATTGAGATGTTGATCAAGTCCATATACAAACCACATCTCATGAAG CAGTTACTTGAGGAGGAGCCATACATAATTTCCTGGCAATAGTCTCCCСTTCAATTTTAATTGCCATGTACAACTCTGGAACTTTTGAGCAGGCGT TACAAATGTGGTTGCCAAATACAATGAGGTTAGCTAACCTCGCTGCCATCTTGTCAGCCTTGGCGCAAAAGTTAACTTTGGCAGACTTGTTCGTCCA GCAGCGTAATTTGATTAATGAGTATGCGCAGGTAATTTTGGACAATCTGATTGACGGTGTCAGGGTTAACCATTCGCTATCCCTAGCAATGGAAATT GTTACTATTAAGCTGGCCACCCAAGAGATGGACATGGCGTTGAGGGAAGGTGGCTATGCTGTGACCTCTGAAAAGGTGCATGAAATGTTGGAAAAAA ACTATGTAAAGGCTTTGAAGGATGCATGGGACGAATTAACTTGGTTGGAAAAATTCTCCGCAATCAGGCATTCAAGAAAGCTCTTGAAATTTGGGCG AAAGCCTTTAATCATGAAAAACACCGTAGATTGCGGCGGACATATAGACTTGTCTGTGAAATCGCTTTTCAAGTTCCACTTGGAACTCCTGAAGGGA ACCATCTCAAGAGCCGTAAATGGTGGTGCAAGAAAGGTAAGAGTAGCGAAGAATGCCATGACAAAAGGGGTTTTTCTCAAAATCTACAGCATGCTTC CTGACGTCTACAAGTTTATCACAGTCTCGAGTGTCCTTTCCTTGTTGTTGACATTCTTATTTCAAATTGACTGCATGATAAGGGCACACCGAGAGGC GAAGGTTGCTGCACAGTTGCAGAAAGAGAGCGAGTGGGACAATATCATCAATAGAACTTTCCAGTATTCTAAGCTTGAAAATCCTATTGGCTATCGC TCTACAGCGGAGGAAAGACTCCAATCAGAACACCCCGAGGCTTTCGAGTACTACAAGTTTTGCATTGGAAAGGAAGACCTCGTTGAACAGGCAAAAC AACCGGAGATAGCATACTTTGAAAAGATTATAGCTTTCATCACACTTGTATTAATGGCTTTTGACGCTGAGCGGAGTGATGGAGTGTTCAAGATACT CAATAAGTTCAAAGGAATACTGAGCTCAACGGAGAGGGAGATCATCTACACGCAGAGTTTGGATGATTACGTTACAACCTTTGATGACAATATGACA ATCAACCTCGAGTTGAATATGGATGAACTCCACAAGACGAGCCTTCCTGGAGTCACTTTTAAGCAATGGTGGAACAACCAAATCAGCCGAGGCAACG TGAAGCCACATTATAGAACTGAGGGGCACTTCATGGAGTTTACCAGAGATACTGCGGCATCGGTTGCCAGCGAGATATCACACTCACCCGCAAGAGA TTTTCTTGTGAGAGGTGCTGTTGGATCTGGAAAATCCACAGGACTTCCATACCATTTATCAAAGAGAGGGAGAGTGTTAATGCTTGAGCCTACCAGA CCACTCACAGATAACGTGCACAAGCAACTGAGAAGTGAACCATTTAACTGCTTCCCAACTTTGAGGATGAGAGGGAAGTCAACTTTTGGGTCATCAC CGATTACAGTCATGACTAGTGGATTCGCTTTACACCATTTTGCACGAAACATAGCTGAGGTAAAAACATACGATTTTGTCATAATTGATGAATGTCA TGTGAATGATGCTTCTGCTATAGCGTTTAGGAATCTACTGTTTGAACATGAATTTGAAGGAAAAGTCCTCAAAGTGTCAGCCACACCACCAGGTAGA GAAGTTGAATTCACAACTCAGTTTCCCGTGAAACTCAAGATAGAAGAGGCTCTTAGCTTTCAGGAATTTGTAAGTTTACAAGGGACAGGTGCCAACG CCGATGTGATTAGTTGTGGCGACAACATACTAGTATATGTTGCTAGCTACAATGATGTTGATAGTCTTGGCAAGCTCCTTGTGCAAAAGGGATACAA AGTGTCGAAGATTGATGGAAGAACAATGAAGAGTGGAGGAACTGAAATAATCACTGAAGGTACTTCAGTGAAAAAGCATTTCATAGTCGCAACTAAT ATTATTGAGAATGGTTAACCATTGACATTGATGTAGTTGTGGATTTTGGGACTAAGGTTGTACCAGTTTTGGATGTGGACAATAGAGCGGTGCAGT ACAACAAAACTGTGGTGAGTTATGGGGAGCGCATCCAAAGACTCGGTAGAGTTGGGCGACACAAGGAAGGAGTAGCACTTCGAATTGGCCAAACAAA TAAAACACTGGTTGAAATTCAGAAATGGTTGCCACTGAAGCTGCCTTTCTATGCTTCATGTACAATTTGCCAGTGACAACACAGAGTGTTTCAACC ACACTGCTGGAAAATGCCACATTATTACAAGCTAGAACTATGGCACAGTTTGAGCTATCATATTTTTACACAATTAATTTTGTGCGATTTGATGGTA GTATGCATCCAGTCATACATGACAAGCTGAAGCGCTTTAAGCTACACACTTGTGAGACATTCCTCAATAAGTTGGCGATCCCAAATAAAGGCTTATC СTCTTGGCTTACGAGTGGAGAGTATAAGCGACTTGGTTACATAGCAGAGGATGCTGGCATAAGAATCCCATTCGTGTGCAAAGAAATTCCAGACTCC TTGCATGAGGAAATTGGCACATTGTAGTCGCCCATAAAGGTGACTCGGGTATTGGGAGGCTCACTAGCGTACAGGCAGCAAAGGTTGTTTATACTC TGCAAACGGATGTGCACTCAATTGCGAGGACTCTAGCATGCATCAATAGACTCATAGCACATGAACAAATGAAGCAGAGTCATTTTGAAGCCGCAAC TGGGAGAGCATTTTCCTTCACAAATTACTCAATACAAAGCATATTTGACACGCTGAAAGCAAATTATGCTACAAAGCATACGAAAGAAAATATTGCA GTGCTTCAGCAGGCAAAAGATCAATTGCTAGAGTTTTCGAACCTAGCAAAGGATCAAGATGTCACGGGTATCATCCAAGACTTCAATCACCTGGAAA СTATCTATCTCCAATCAGATAGCGAAGTGGCTAAGCATCTGAAGCTTAAAAGTCACTGGAATAAAAGCCAAATCACTAGGGACATCATAATAGCTTT GTCTGTGTTAATTGGTGTGGATGGATGCTTGCAACGTACTTCAAGGACAAGTTCAATGAACCAGTCTATTTCCAAGGGAAGAAGAATCAGAAGCAC AAGCTTAAGATGAGAGAGGCGCGTGGGGCTAGAGGGCAATATGAGGTTGCAGCGGAGCCAGAGGCGCTAGAACATTACTTTGGAAGCGCATATAATA ACAAAGGAAAGCGCAAGGGCACCACGAGAGGAATGGGTGCAAAGTCTCGGAAATTCATAAACATGTATGGGTTTGATCCAACTGATTTTTCATACAT 
TAGGTTTGTGGATCCATTGACAGGTCACACTATTGATGAGTCCACAAACGCACCTATTGATTTAGTGCAGCATGAGTTTGGAAAGGTTAGAACACGC ATGTTAATTGACGATGAGATAGAGCCTCAAAGTCTTAGCACCCACACCACAATCCATGCTTATTTGGTGAATAGTGGCACGAAGAAAGTTCTTAAGG TTGATTTAACACCACACTCGTCGCTACGTGCGAGTGAGAAATCAACAGCAATAATGGGATTTCCTGAAAGGGAGAATGAATTGCGTCAAACCGGCAT GGCAGTGCCAGTGGCTTATGATCAATTGCCACCAAAGAGTGAGGACTTGACGTTTGAAGGAGAAAGCTTGTTTAAGGGACCACGTGATTACAACCCG ATATCGAGCACCATTTGTCACTTGACGAATGAATCTGATGGGCACACAACATCGTTGTATGGTATTGGATTTGGTCCCTTCATCATTACAAACAAGC ACTTGTTTAGAAGAAATAATGGAACACTGTTGGTCCAATCACTACATGGTGTATTCAAGGTCAAGAACACCACGACTTTGCAACAACACCTCATTGA TGGGAGGGACATGATAATTATTCGCATGCCTAAGGATTTCCCACCATTTCCTCAAAAGCTGAAATTTAGAGAGCCACAAAGGGAAGAGCGCATATGT СTTGTGACAACCAACTTCCAAACTAAGAGCATGTCTAGCATGGTGTCAGACACTAGTTGCACATTCCCTTCATCTGATGGCATATTCTGGAAGCATT GGATTCAAACCAAGGATGGGCAGTGTGGCAGTCCATTAGTATCAACTAGAGATGGGTTCATTGTTGGTATACACTCAGCATCGAATTTCACCAACAC AAACAATTATTTCACAAGCGTGCCGAAAAACTTCATGGAATTGTTGACAAATCAGGAGGCGCAGCAGTGGGTTAGTGGTTGGCGATTAAATGCTGAC TCAGTATTGTGGGGGGGCCATAAAGTTTTCATGAGCAAACCTGAAGAGCCTTTTCAGCCAGTTAAGGAAGCGACTCAACTCATGAGTGAATTGGTGT ACTCGCAAGGGGAGAAGAGGAAATGGGTCGTGGAAGCACTGTCAGGGAACTTGAGGCCAGTGGCTGAGTGTCCCAGTCAGTTAGTCACAAAGCATGT GGTTAAAGGAAAGTGTCCCCTCTTTGAGCTCTACTTGCAGTTGAATCCAGAAAAGGAAGCATATTTTAAACCGATGATGGGAGCATATAAGCCAAGT CGACTTAATAGAGAGGCGTTCCTCAAGGACATTCTAAAATATGCTAGTGAAATTGAGATTGGGAATGTGGATTGTGACTTGCTGGAGCTTGCAATAA GCATGCTCATCACAAAGCTCAAGGCGTTAGGATTCCCAACTGTGAACTACATCACTGACCCAGAGGAAATTTTTAGTGCATTGAATATGAAAGCAGC TATGGGAGCACTATACAAAGGCAAGAAGAAAGAAGCTCTCAGCGAGCTCACACTAGATGAGCAGGAGGCAATGCTCAAAGCAAGTTGCCTGCGACTG TATACGGGAAAGCTGGGAATTTGGAATGGCTCATTGAAAGCAGAGTTGCGTCCAATTGAGAAGGTTGAAAACAACAAAACGCGAACTTTCACAGCAG CACCAATAGACACTCTTCTTGCTGGTAAAGTTTGCGTGGATGATTTCAACAATCAATTTTATGATCTCAACATAAAGGCACCATGGACAGTTGGTAT GACTAAGTTTTATCAGGGGTGGAATGAATTGATGGAGGCTTTACCAAGTGGGTGGGTGTATTGTGACGCTGATGGTTCGCAATTCGACAGTTCCTTG ACTCCATTCCTCATTAATGCTGTATTGAAAGTGCGACTTGCCTTCATGGAGGAATGGGATATTGGTGAGCAAATGCTGCGAAATTTGTACACTGAGA TAGTGTATACACCAATCCTCACACCGGATGGTACTATCATTAAGAAGCATAAAGGCAACAATAGCGGGCAACCTTCAACAGTGGTGGACAACACACT CATGGTCATTATTGCAATGTTATACACATGTGAGAAGTGTGGAATCAACAAGGAAGAGATTGTGTATTACGTCAATGGCGATGACCTATTGATTGCC ATTCACCCAGATAAAGCTGAGAGGTTGAGTGGATTCAAAGAATCTTTCGGAGAGTTGGGCCTGAAATATGAATTTGACTGCACCACCAGGGACAAGA CACAGTTGTGGTTCATGTCACACAGGGCTTTGGAGAGGGATGGCATGTATATACCAAAGCTAGAAGAAGAAAGGATTGTTTCTATTTTGGAATGGGA CAGATCCAAAGAGCCGTCACATAGGCTTGAAGCCATCTGTGCATCAATGATCGAAGCATGGGGTTATGACAAGCTGGTTGAAGAAATCCGCAATTTC TATGCATGGGTTTTGGAACAAGCGCCGTATTCACAGCTTGCAGAAGAAGGAAAGGCGCCATATCTGGCTGAGACTGCGCTTAAGTTTTTGTACACAT CTCAGCACGGAACAAACTCTGAGATAGAAGAGTATTTAAAAGTGTTGTATGATTACGATATTCCAACGACTGAGAATCTTTATTTTCAGAGTGGCAC TGTGGGTGCTGGTGTTGACGCTGGTAAGAAGAAAGATCAAAAGGATGATAAAGTCGCTGAGCAGGCTTCAAAGGATAGGGATGTTAATGCTGGAACT TCAGGAACATTCTCAGTTCCACGAATAAATGCTATGGCCACAAAACTTCAATATCCAAGGATGAGGGGAGAGGTGGTTGTAAACTTGAATCACCTTT TAGGATACAAGCCACAGCAAATTGATTTGTCAAATGCTCGAGCCACACATGAGCAGTTTGCCGCGTGGCATCAGGCAGTGATGACAGCCTATGGAGT GAATGAAGAGCAAATGAAAATATTGCTAAATGGATTTATGGTGTGGTGCATAGAAAATGGGACTTCCCCAAATTTGAACGGAACTTGGGTTATGATG GATGGTGAGGAGCAAGTTTCATACCCGCTGAAACCAATGGTTGAAAACGCGCAGCCAACACTGAGGCAAATTATGACACACTTCAGTGACCTGGCTG AAGCGTATATTGAGATGAGGAATAGGGAGCGACCATACATGCCTAGGTATGGTCTACAGAGAAACATTACAGACATGAGTTTGTCACGCTATGCGTT CGACTTCTATGAGCTAACTTCAAAAACACCTGTTAGAGCGAGGGAGGCGCATATGCAAATGAAAGCTGCTGCAGTACGAAACAGTGGAACTAGGTTA TTTGGTCTTGATGGCAACGTGGGTACTGCAGAGGAAGACACTGAACGGCACACAGCGCACGATGTGAACCGTAACATGCACACACTATTAGGGGTCC GCCAGTGATAGTTTCTGCGTGTCTTTGCTTTCCGCTTTTAAGCTTATTGTAATATATATGAATAGCTATTCACAGTGGGACTTGGTCTTGTGTTGAA TGGTATCTTATATGTTTTAATATGTCTTATTAGTCTCATTACTTAGGCGAACGACAAAGTGAGGTCACCTCGGTCTAATTCTCCTATGTAGTGCGAG AAAAAAAAAAAAAAAAAAAAAAAAAAAAAAAAAAAAAAAAAAAAAGATCTCGCTGAAATCACCAGTCTCTCTCTACAAATCTATCTCTCTCTATTTT CTCCATAAATAATGTGTGAGTAGTTTCCCGATAAGGGAAATTAGGGTTCTTATAGGGTTTCGCTCATGTGTTGAGCATATAAGAAACCCTTAGTATG TATTTGTATTTGTAAAATACTTCTATCAATAAAATTTCTAATTCCTAAAACCAAAATCCAGGGGCCCTCGACGTTCCTTGACAGGATATATTGGCGG GTAAACTAAGTCGCTGTATGTGTTTGTTTGAGATCCTCTAGGGCATGCAAGCTGATCTGGATCTCATGTGAGCAAAAGGCCAGCAAAAGGCCAGGAA CCGTAAAAAGGCCGCGTTGCTGGCGTTTTTCCATAGGCTCCGCCCCCCTGACGAGCATCACAAAAATCGACGCTCAAGTCAGAGGTGGCGAAACCCG ACAGGACTATAAAGATACCAGGCGTTTCCCCCTGGAAGCTCCCTCGTGCGCTCTCCTGTTCCGACCCTGCCGCTTACCGGATACCTGTCCGCCTTTC TCCCTTCGGGAAGCGTGGCGCTTTCTCATAGCTCACGCTGTAGGTATCTCAGTTCGGTGTAGGTCGTTCGCTCCAAGCTGGGCTGTGTGCACGAACC CCCCGTTCAGCCCGACCGCTGCGCCTTATCCGGTAACTATCGTCTTGAGTCCAACCCGGTAAGACACGACTTATCGCCACTGGCAGCAGCCACTGGT AACAGGATTAGCAGAGCGAGGTATGTAGGCGGTGCTACAGAGTTCTTGAAGTGGTGGCCTAACTACGGCTACACTAGAAGAACAGTATTTGGTATCT GCGCTCTGCTGAAGCCAGTTACCTTCGGAAGAAGAGTTGGTAGCTCTTGATCCGGCAAACAAACCACCGCTGGTAGCGGTGGTTTTTTTGTTTGCAA GCAGCAGATTACGCGCAGAAAAAAAGGATCTCAAGAAGATCCTTTGATCTTTTCTACGGGGTCTGACGCTCAGTGGAACGAAAACTCACGTTAAGGG ATTTTGGTCATGAGATTATCAAAAAGGATCTTCACCTAGATCCTTTTAAATTAAAAATGAAGTTTTAAATCAATCTAAAGTATATATGTGTAACATT GGTCTAGTGATTAGAAAAACTCATCGAGCATCAAATGAAACTGCAATTTATTCATATCAGGATTATCAATACCATATTTTTGAAAAAGCCGTTTCTG TAATGAAGGAGAAAACTCACCGAGGCAGTTCCATAGGATGGCAAGATCCTGGTATCGGTCTGCGATTCCGACTCGTCCAACATCAATACAACCTATT AATTTCCCCTCGTCAAAAATAAGGTTATCAAGTGAGAAATCACCATGAGTGACGACTGAATCCGGTGAGAATGGCAAAAGTTTATGCATTTCTTTCC AGACTTGTTCAACAGGCCAGCCATTACGCTCGTCATCAAAATCACTCGCATCAACCAAACCGTTATTCATTCGTGATTGCGCCTGAGCGAGACGAAA TACGCGATCGCTGTTAAAAGGACAATTACAAACAGGAATCGAATGCAACCGGCGCAGGAACACTGCCAGCGCATCAACAATATTTTCACCTGAATCA GGATATTCTTCTAATACCTGGAATGCTGTTTTCCCTGGGATCGCAGTGGTGAGTAACCATGCATCATCAGGAGTACGGATAAAATGCTTGATGGTCG GAAGAGGCATAAATTCCGTCAGCCAGTTTAGTCTGACCATCTCATCTGTAACAACATTGGCAACGCTACCTTTGCCATGTTTCAGAAACAACTCTGG CGCATCGGGCTTCCCATACAATCGGTAGATTGTCGCACCTGATTGCCCGACATTATCGCGAGCCCATTTATACCCATATAAATCAGCATCCATGTTG GAATTTAATCGCGGCCTTGAGCAAGACGTTTCCCGTTGAATATGGCTCATAACACCCCTTGTATTACTGTTTATGTAAGCAGACAGTTTTATTGTTC ATGATGATATATTTTTATCTTGTGCAATGTAACATCAGAGATTTTGAGACACAACGTGGCTTTGTTGAATAAATCGAACTTTTGCTGAGTTGAAGGA TCAGATCACGCATCTTCCCGACAACGCAGACCGTTCCGTGGCAAAGCAAAAGTTCAAAATCACCAACTGGTCCACCTACAACAAAGCTCTCATCAAC CGTGGCTCCCTCACTTTCTGGCTGGATGATGGGGCGATTCAGGC GATCCCCATCCAACAGCCCGCCGTCGAGCGGGCTTTTTTATCCCCGGAAGCCT GTGGATAGAGGGTAGTTATCCACGTGAAAACCGCTAATGCCCCGCAAAACCCTTGATTCACGGGGCTTTCCGECCCGCTCCAAAAAACTATCCACGTGA슥 ATCGCTAATCAGGGTACGTGAAATCGCTAATCGGAGTACGTGAAATCGCTAATAAGGTCACGTGAAATCGCTAATCAAAAAGGCACGTGAGAACGCT AATAGCCCTTTCAGATCAACAGCTTGCAAACACCCCTCGCTCCGGCAAGTAGTTACAGCAAGTAGTATGTTCAATTAGCTTTTCAATTATGAATATA TATATCAATTATTGGTCGCCCTTGGCTTGTGGACAATGCGCTACGCGCACCGGCTCCGCCCGTGGACAACCGCAAGCGGTTGCCCACCGTCGAGCGC СTTTGCCCACAACCCGGCGGCCGGCCCAACAGATCGTTTTATAAATTTTTTTTTTTGAAAAAGAAAAAGCCCGAAAGGCGGCAACCTCTCGGGCTT CTGGATTTCCGATCCCCGGAATTAGATCCGTTTAAACTACGTAAGATCGATCTTGGCAGGATATATTGTGGTGTAAACGTTCCTGCGGCGGTCGAGA TGGATCTTGGCAGGATATATTGTGGTGTAAACGTTCCTGCGGCCGC 
CAPÍTULO 4. RESULTADOS:

CONSTRUCCIÓN DE UN VECTOR VIRAL DESARMADO PARA LA EXPRESIÓN SIMULTÁNEA DE MÚLTIPLES PROTEÍNAS, BASADO EN EL VIRUS DEL GRABADO DEL TABACO (TEV) 
Journal of Biotechnology 150: 268-275 (2010)

\section{Simultaneous equimolar expression of multiple proteins in plants from a disarmed potyvirus vector}

Leonor Bedoya, Fernando Martínez, Laura Rubio, José-Antonio Darós

Instituto de Biología Molecular y Celular de Plantas (CSIC-Universidad Politécnica de Valencia), Avenida de los Naranjos, 46022 Valencia, Spain

\section{ABSTRACT}

The use of viral vectors for expression of heterologous proteins in plants is hampered by some limitations including the amount of exogenous genetic information that can be incorporated, difficulties with coexpression of stoichiometric amounts of multiple polypeptides and the risk that infectious clones could escape to environment. Here, a new plant viral vector is described which overcomes these limitations. The technology is based on the replacement of the viral RNA polymerase ( $\mathrm{Nlb}$ ) cistron of a potyvirus by a cassette for the coexpression of multiple heterologous proteins. The heterologous proteins are flanked by specific cleavage motifs of a viral protease that mediate their efficient release from the viral polyprotein. The vector only replicates and moves systemically in plants where the viral Nlb activity is supplied in trans by a transgene or another viral vector. The vector allowed for simultaneous expression of three fluorescent reporter proteins in the same subcellular location or two interacting transcription factors inducing anthocyanin accumulation. The vector had sufficient stability throughout the infectious cycle and the Nlb deletion prevented infection of wildtype plants which improves biosecurity.

\section{Introduction}

Plants and their viruses form an attractive combination from a biotechnological perspective: plants are ideal biofactories whose expression pattern can be programmed through engineered viral vectors. Through the simple and ingenious manipulation of infectious clones of multiple plant viruses, heterologous gene products of interest have been rapidly and efficiently expressed (Pogue et al., 2002; Cañizares et al., 2005; Gleba et al., 2007; Lico et al., 2008; Shih and Doran, 2009; Sainsbury et al., 2010). One virus group that has traditionally attracted interest in plant biotechnology is the potyviruses (genus Potyvirus, family Potyviridae). These plant viruses consist of a (+) polarity RNA 
of circa $10 \mathrm{~kb}$, with a 5' genome linked viral protein (VPg) and a 3' poly (A) tail, encapsidated in flexuous and elongated virions. The genome encodes a polyprotein which is processed in a regulated way by three viral proteases into about ten mature gene products (Urcuqui-Inchima et al., 2001), plus P3N-PIPO resulting from a translational frame shift (Chung et al., 2008; Wei et al., 2010). The proteases P1 and helper-component (HC-Pro), in the amino terminal end of the polyprotein, catalyze their own processing, while nuclear inclusion "a" protease (NlaPro), or its non-completely processed form (Nla), in which the NlaPro domain is still joined to VPg, catalyzes the remaining cleavages in cis and in trans, recognizing a conserved processing motif of seven amino acids $(-6 /+1)$ surrounding the cleavage site (Adams et al., 2005).

Several features make potyviruses appealing as expression vectors. Their expression via a polyprotein which is processed into a series of mature gene products allows for production of heterologous proteins in an amount equimolar to the rest of viral proteins (Dolja et al., 1992; Carrington et al., 1993). If the heterologous proteins are flanked by the specific processing sites of a viral protease, they are efficiently released from the polyprotein (Carrington et al., 1993). The use of different insertion sites allows for coexpression of several heterologous proteins from a single vector (Masuta et al., 2000; Beauchemin et al., 2005; Kelloniemi et al., 2008). The elongated nature of the virion allows it to accommodate large amounts of extraneous genetic material (Kelloniemi et al., 2008). Moreover, potyviruses constitute an extraordinarily diverse group infecting a large number of host plant species (Fauquet et al., 2005), making heterologous technologies broadly applicable.

The use of viral vectors to express heterologous gene products in plants has several limitations. One is the amount of heterologous genetic information that can be expressed from a single vector. Another is difficulties with coexpression of stoichiometric amounts of multiple polypeptides. Finally, there is the risk that recombinant viral vectors could escape to environment. Here, we attempt to overcome these limitations by developing a new vector based on the potyvirus Tobacco etch virus (TEV). The vector is based on two early findings in TEV molecular biology. First, the viral protease NlaPro (or its unprocessed form NIa) efficiently cleaves an artificial proteolytic site introduced in between a $\beta$-glucuronidase reporter gene and viral HC-Pro (Carrington et al., 1993). Second, a TEV mutant with a deletion of the whole viral RNA polymerase (nuclear inclusion "b" protein, NIb) cistron (TEVANIb) can be complemented in trans in a transgenic plant expressing this protein ( $\mathrm{Li}$ and Carrington, 1995). 
Furthermore, recent construction of a stable binary plasmid (pGTEV), containing a TEV infectious clone under the control of the Cauliflower mosaic virus (CaMV) $35 \mathrm{~S}$ promoter and terminator allows efficient infection of host plants by agroinoculation (Bedoya and Daròs, 2010). In the work described here, the Nlb cistron of a TEV infectious clone was replaced by cassettes to coexpress proteins that were flanked by natural and artificial cleavage sites of the viral protease NlaPro. The resulting vectors were stable and exclusively replicated and moved in plants where viral Nlb was supplied in trans through a transgene or compatible viral vector. Using this vector we show the coexpressions of up to three different fluorescent proteins in the same subcellular location. We also show the potential use of this vector in metabolic engineering by coexpressing two interacting transcription factors that very efficiently induced accumulation of anthocyanins in infected tissue.

\section{Materials and methods}

\subsection{Plasmid construction}

The pGTEV plasmid contains a TEV infectious cDNA (Genbank accession number DQ986288) flanked by CaMV 35S promoter and terminator (Bedoya and Darós, 2010). Plasmid pTEV89 contains a cDNA fragment of TEV-DQ986288 (positions 6506-9059) inserted in the Smal site of pBluescript II KS + (Genbank accession number X52327). This cDNA fragment includes the complete Nlb cistron flanked by restriction sites Eco81l and Blnl that are unique in pGTEV. Plasmid pgR107 (Genbank accession number AY297842) contains a Potato virus $X$ (PVX) infectious clone including a duplicated coat protein (CP) promoter ahead of a small polylinker (Lu et al., 2003). Plasmid pmCherry contains the cDNA of the red fluorescent protein mCherry (Genbank accession number AY678264) (Shaner et al., 2004). Plasmid pDH51-GW-YFP (Genbank accession number AM773752) (Zhong et al., 2008) contains the CDNA of the yellow fluorescent protein Venus (Nagai et al., 2002). Plasmid pmTagBFP contains the cDNA of the blue fluorescent protein mTagBFP (Subach et al., 2008) as in plasmid pTagBFP-N (Evrogen) but including the silent mutation G258A in the mTagBFP cDNA to remove an Eco81I site.

PCR amplification for plasmid construction was performed in $20 \mu \mathrm{l}$ with $0.4 \mathrm{U}$ of the high fidelity Phusion DNA polymerase (Finnzymes) in HF buffer (Finnzymes), 3\% dimethyl sulfoxide, $0.2 \mathrm{mM}$ dNTPs, $0.5 \mu \mathrm{M}$ each primer and $10 \mathrm{ng}$ of template DNA. The 
reactions were incubated $30 \mathrm{~s}$ at $98^{\circ} \mathrm{C}$ followed by 30 cycles of $10 \mathrm{~s}$ at $98^{\circ} \mathrm{C}, 30 \mathrm{~s}$ at $55 \stackrel{\circ}{\circ}$ and a variable extension time depending on the length of the expected product $(15 \mathrm{~s} / \mathrm{kb})$ at $72{ }^{\circ} \mathrm{C}$, and a final extension of $10 \mathrm{~min}$ at $72{ }^{\circ} \mathrm{C}$. The constructs were transformed by electroporation into Escherichia coli strain DH5a. mCherry cDNA including an amino terminal FLAG tag was amplified from pmCherry with primers $\mathrm{PI}$ and PII (the sequences and features of all primers are detailed in supplementary Table S1). Venus cDNA including an amino terminal HA tag was amplified from pDH51-GW-YFP with primers PIII and PIV. mTagBFP cDNA including an amino terminal c-Myc tag was amplified from pmTagBFP with primers PV and PVI. These three cDNAs digested with Eco31I (Fermentas) were ligated to the PCR product resulting from amplification of pTEV89 with primers PVII and PVIII also digested with Eco31I. In the resulting plasmids pTEV89cNIb-Cherry, pTEV89 $\triangle$ NIb-Venus and pTEV89 $\triangle$ NIb-Blue, each one of the tagged fluorescent protein cDNAs FLAG-mCherry, HA-Venus and c-Myc-mTagBFP, substitute most of NIb cistron and are flanked by the natural NlaPro proteolysis sites NlaPro/NIb and NIb/CP.

The three fluorescent protein cDNAs including the corresponding tags were amplified again to construct the cassette to coexpress the three proteins simultaneously. FLAGmCherry cDNA was amplified from pTEV89 $\mathrm{N}$ Ib-Cherry with primers PI and PIX. HAVenus cDNA was amplified from pTEV89 $\Delta$ NIb-Venus with primers PX and PXI. c-MycmTagBFP cDNA was amplified from pTEV89 NNIb-Blue with primers PXII and PVI. The three cDNAs were digested with Eco31I and ligated to the product of amplification of pTEV89 with primers PVII and PVIII also digested with Eco31I, as described above. The plasmid resulting from assembly of the four DNA fragments was named pTEV89 $\triangle \mathrm{NIb}$ CVB and contains the FLAG-mCherry, HA-Venus and c-Myc-mTagBFP cDNAs separated by two artificial NlaPro proteolysis sites, substituting most of the NIb cistron and flanked by the natural NlaPro proteolysis sites NlaPro/NIb and NIb/CP.

Similarly, the cDNAs of snapdragon (Antirrhinum majus L.) transcription factors Delila and Rosea1 were amplified from a DNA preparation obtained from a transgenic tomato expressing these genes (Butelli et al., 2008) with primers PXIII-PXIV and PXV-PXVI. Both cDNAs were digested with Eco31I and the products ligated, as described above, to the product of amplification of pTEV89 with primers PVII and PVIII. The resulting plasmid pTEV89 $\Delta$ NIb-DelRos contains the Delila and Rosea1 cDNAs separated by an artificial NlaPro proteolysis site, replacing most of NIb cistron and flanked by natural proteolysis sites NlaPro/NIb and NIb/CP. Finally, the Eco81I-BInl cDNA fragment from 
pGTEV was exchanged with each of the Eco81I-BInl restriction fragments from plasmids pTEV89 $\Delta$ NIb-Cherry, pTEV89 $\Delta$ NIb-Venus, pTEV89 $\Delta$ NIb-Blue, pTEV89 $\Delta$ NIbCVB and pTEV89 $\Delta$ NIb-DelRos containing the corresponding expression cassettes, to construct the expression vectors pGTEVANIb-Cherry, pGTEVANIb-Venus, pGTEVANIb-Blue, pGTEVANIb-CVB and pGTEVANIb- DelRos, respectively.

Plasmid pgR107-Nlb was constructed by inserting the complete TEV NIb cDNA, including an amino terminal ATG and a carboxy terminal UGA stop codon, amplified from pGTEV with primers PXVII and PXVIII and digested with Eco31I into plasmid pgR107 opened with Smal-Sall. The resulting plasmid was named pgR107-NIb and contains the TEV NIb cDNA under the control of the duplicated PVX CP promoter.

\subsection{Plant inoculation}

Wild-type tobacco plants (Nicotiana tabacum L. cv. Xanthi nc), transgenic plants from this same cultivar expressing TEV NIb plus an additional amino terminal Met (Li and Carrington, 1995) and wild-type Nicotiana benthamiana Domin plants about 6 weeks old were infiltrated in the two youngest expanded leaves (two infiltrations per leaf) and cultivated in a growth chamber under a photoperiod of $16 \mathrm{~h}$ day at $25^{\circ} \mathrm{C}$ and $8 \mathrm{~h}$ night at $23{ }^{\circ} \mathrm{C}$. The agroinoculation was done with cultures of Agrobacterium tumefaciens C58C1 containing the helper plasmid pCLEAN-S48 (Thole et al., 2007) and the plasmids (singly or in various combinations) pGTEV, pGTEV $\triangle$ NIb-Cherry, pGTEV $\triangle$ NIbVenus, pGTEVANIb-Blue, pGTEV $\Delta$ NIb-CVB, pGTEV $\Delta$ NIb-DelRos or pgR107-NIb, adjusted to an OD (600 nm) of approximately 0.5 and induced for $2 \mathrm{~h}$ at $28{ }^{\circ} \mathrm{C}$ with 150 $\mu \mathrm{M}$ acetosyringone in $10 \mathrm{mM}$ MES-NaOH, $\mathrm{pH} 5.6,10 \mathrm{mM} \mathrm{MgCl}_{2}$ (Bedoya and Daròs, 2010).

The plants were also inoculated mechanically with homogenates of infected tissues. Crude homogenates were obtained from $100 \mathrm{mg}$ of frozen tissue ground in a 2-ml Eppendorf tube with a 4-mm diameter stainless steel ball using a Retsch MM300 mill for $1 \mathrm{~min}$ at a $30 \mathrm{~s}^{-1}$ frequency and a total of $2 \mathrm{ml}$ (20 volumes) of buffer $\mathrm{Tl}$ (50 mM potassium phosphate, $\mathrm{pH} 8.0,1 \%$ polyvinylpyrrolidone $10,1 \%$ polyethylene glycol 6000 , $10 \mathrm{mM} 2$-mercaptoethanol) added. The two youngest expanded leaves were inoculated by depositing two 10- $\mu$ l drops (one per leaf side) of $10 \%$ Carborundum in $\mathrm{TI}$ and gently rubbing with a cotton swab soaked with the crude homogenates. 


\subsection{Analysis of fluorescent proteins}

Fluorescent proteins were observed with a fluorescence stereomicroscope Leica MZ 16 F equipped with filters DSR, GFP2 and V (Leica). Exposure times were of $10.1 \mathrm{~ms}$ (white light) and $5.1 \mathrm{~s}$ (fluorescence). Tissue sections mounted with Moviol were observed with a confocal microscope (Leica TCS-SP2-AOBS) using a HCX PL APO $63 X / 1.4$ oil lens with excitation lasers of 405,488 and $594 \mathrm{~nm}$ and detection windows of 420-470, 520-550 and 610-670 nm, respectively. The fluorescent proteins were also detected by western blot using specific antibodies against their corresponding tags. For this purpose, $0.1 \mathrm{~g}$ of frozen tissue was ground with the mill as indicated above and suspended in $300 \mu \mathrm{l}$ of buffer TEW $(60 \mathrm{mM}$ Tris- $\mathrm{HCl}, \mathrm{pH} 6.8,2 \%$ sodium dodecyl sulfate, $100 \mathrm{mM}$ dithiothreitol, 10\% glycerol, 0.01\% bromophenol blue). After $5 \mathrm{~min}$ at 98 $\stackrel{\circ}{ } \mathrm{C}$ the extract was vortexed and clarified by centrifuging $15 \mathrm{~min}$. Supernatants $(20 \mu \mathrm{l}$, equivalent to approximately $6.7 \mathrm{mg}$ fresh tissue) were separated by SDS-PAGE in discontinuous gels, with a stacking gel of $5 \%$ polyacrylamide and a resolving gel of $12.5 \%$ polyacrylamide both containing $0.05 \%$ SDS. The proteins were electroblotted to PVDF membranes (GE Healthcare) that were blocked for $1 \mathrm{~h}$ in $5 \%$ non-fat milk in buffer WB (10 mM Tris- $\mathrm{HCl}, \mathrm{pH} 7.5,154 \mathrm{mM} \mathrm{NaCl}, 0.1 \%$ Nonidet P40). The incubation with antibodies was overnight at room temperature at 1:10,000 dilution of mouse monoclonal antibodies anti-DYKDDDDK-tag-HRP (Genscript), anti- HA 12CA5 (Roche) and anti-c-Myc-HRP (Genscript) in 5\% non-fat milk in WB. In the case of the anti-HA antibody, the membranes were washed with buffer WB and further incubated for $1 \mathrm{~h}$ at room temperature with a sheep anti-mouse-IgG-HRP secondary antibody (GE Healthcare) at 1:10,000 dilution in 5\% non-fat milk in WB. Finally, all membranes were extensively washed with buffer WB and the horseradish peroxidase (HRP) detected by chemiluminescence with the ECL plus western blotting detection system (GE Healthcare).

\subsection{RT-PCR analysis of viral RNA}

From $50 \mathrm{mg}$ of frozen tissue ground with the mill, RNA was purified using silica gel columns that were eluted in $10 \mu \mathrm{l}$. RNA aliquots of $1 \mu \mathrm{l}$ were reverse transcribed with 50 $U$ of M-MuLV reverse transcriptase (Revertaid, Fermentas), $10 \cup$ RNase inhibitor (Fermentas), $1 \mathrm{mM}$ dNTPs and 5 pmol primer PXIX in $50 \mathrm{mM}$ Tris- $\mathrm{HCl}, \mathrm{pH}$ 8.3, $50 \mathrm{mM}$ 
$\mathrm{KCl}, 4 \mathrm{mM} \mathrm{MgCl}_{2}, 10 \mathrm{mM}$ dithiothreitol for $45 \mathrm{~min}$ at $42{ }^{\circ} \mathrm{C}, 10 \mathrm{~min}$ at $50^{\circ} \mathrm{C}$ and $5 \mathrm{~min}$ at $60 \stackrel{\circ}{\circ}$. The mix of RNA and primer in water was denatured for $1.5 \mathrm{~min}$ at $98^{\circ} \mathrm{C}$ prior to addition of the remaining reagents. For TEV diagnosis, $1 \mu$ laliquots of the RT reactions were used as templates in PCR reactions of $20 \mu \mathrm{l}$ with $1 \mathrm{U}$ of Thermus thermophilus DNA polymerase, $1 \mu \mathrm{M}$ each primer PXX and PXXI, $0.2 \mathrm{mM}$ dNTPs in buffer $75 \mathrm{mM}$ Tris- $\mathrm{HCl}, \mathrm{pH}$ 9.0, $2 \mathrm{mM} \mathrm{MgCl}$, $50 \mathrm{mM} \mathrm{KCl}, 20 \mathrm{mM}\left(\mathrm{NH}_{4}\right)_{2} \mathrm{SO}_{4}$. Reactions were incubated for 2 min at $94{ }^{\circ} \mathrm{C}$ followed by 30 cycles of $40 \mathrm{~s}$ at $94{ }^{\circ} \mathrm{C}, 30 \mathrm{~s}$ at $55^{\circ} \mathrm{C}$ and 3 min at $72{ }^{\circ} \mathrm{C}$, with a final extension of $10 \mathrm{~min}$ at $72{ }^{\circ} \mathrm{C}$. To analyze the integrity of the expression cassettes in the infected plants, the PCR amplification was performed with primers PXXII and PXXIII. In both cases, the PCR products were separated by electrophoresis in 1\% agarose gels in buffer TAE $(40 \mathrm{mM}$ Tris, $20 \mathrm{mM}$ sodium acetate, 1 mM EDTA, pH 7.2) and stained with ethidium bromide.

\section{Results}

3.1. Simultaneous expression of three reporter fluorescent proteins from a defective TEV viral vector

A defective TEV mutant including the complete deletion of the NIb cistron is able to replicate in tobacco plants where the NIb protein is supplied in trans through the expression of a transgene (Li and Carrington, 1995). To check whether this also occurs when the NIb cistron is replaced by a cassette to coexpress multiple heterologous proteins, such a cassette was constructed and inserted in the TEV infectious clone contained in the binary plasmid pGTEV (Fig. 1). The cassette contained the cDNAs of the three reporter fluorescent proteins mCherry, Venus and mTagBFP (Fig. 1 and Fig. S1). These fluorescent proteins have excitation and emission spectra that allow detection without cross interference and belong to different lineages of fluorescent proteins and share little sequence identity. Identical regions of the 5' and 3' termini of mCherry and Venus cDNAs were removed to avoid undesired recombination during virus replication by introducing four silent mutations in mCherry cDNA (Fig. S1). The proteins included amino terminal tags to allow unequivocal detection by specific antibodies: FLAG-mCherry, HA-Venus and c-Myc-mTagBFP (Fig. 1 and Fig. S1). In the expression cassette, the proteins were flanked by the $-8 /+3$ amino acid sequence surrounding the NIb/CP processing site in the TEV polyprotein (TTENLYFQ/SGT) (Fig. 1 and Fig. S1), where the recognition motif is the $-6 /+1$ heptapeptide (ENLYFQ/S) and 
amino acids $-8,-7$ (TT) and $+2,+3$ (GT) probably act as spacers, although a possible influence in processing efficiency cannot be ruled out (Adams et al., 2005). The nucleotide sequences corresponding to these artificial proteolytic sites also included silent mutations, again to avoid long sequence repetitions that may facilitate homologous recombination during viral replication (Fig. S1). The coexpression of the three reporter fluorescent proteins from the defective vector (TEV $\triangle N I b-C V B$ ) was analyzed by supplying the viral NIb activity in two different ways: by transgenic tobacco expressing NIb under the control of CaMV 35S promoter and terminator and in wild-type $N$. benthamiana plants coinoculated with a recombinant version of the compatible virus PVX, expressing NIb (PVX-NIb). In both cases, the supplemented protein was identical to TEV NIb (amino acids 2280-2791 from polyprotein ABJ16044) plus an amino terminal Met.

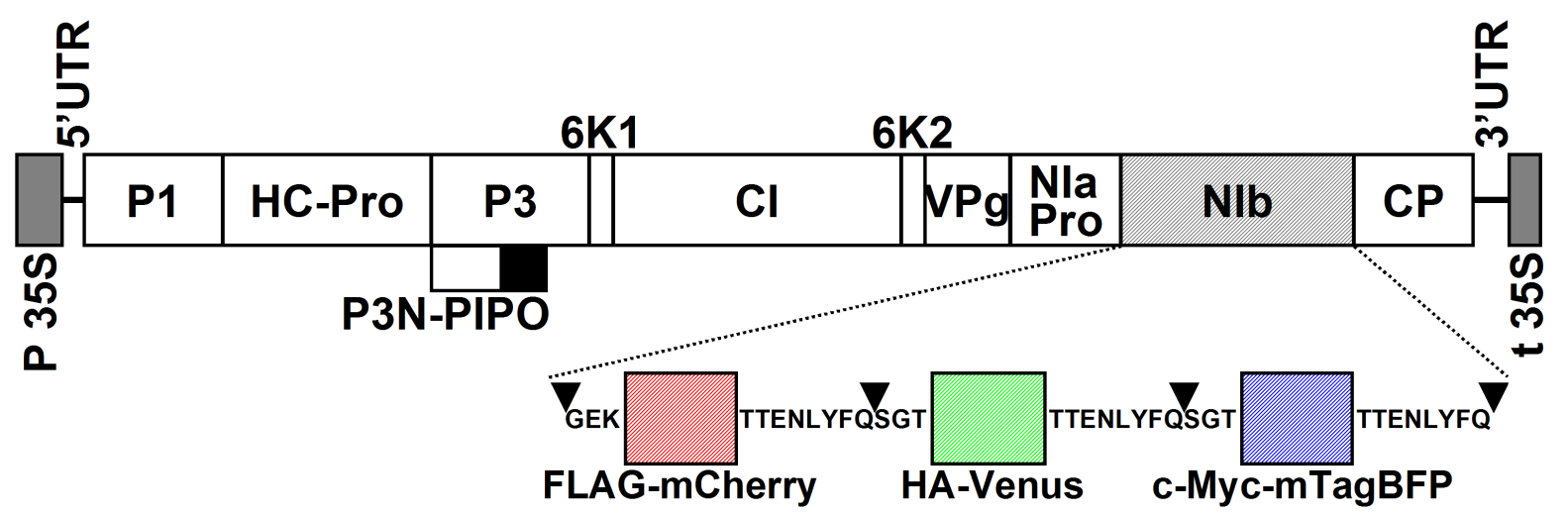

Fig. 1. Diagram of the defective expression vector TEV $\triangle$ NIb-CVB. In the TEV infectious clone contained in pGTEV, the NIb cistron (gray rectangle) is replaced with an expression cassette with the cDNAs of the three tagged reporter fluorescent proteins FLAG-mCherry (red rectangle), HA-Venus (green rectangle) and c-Myc-mTagBFP (blue rectangle) flanked by proteolytic processing sites of viral protease NlaPro. Indicated in the diagram are the positions of CaMV $35 S$ promoter ( $P$ 35S) and terminator (t 35S) (dark gray rectangles), TEV genome untranslated regions (5'UTR and 3'UTR) (black lines) and the remaining TEV cistrons (P1, HC-Pro, P3, P3NPIPO, 6K1, Cl, 6K2, VPg, Nla Pro and CP). Arrowheads indicate the proteolytic cleavage sites in the expression cassette. (For interpretation of the references to color in this figure legend, the reader is referred to the web version of the article.)

Transgenic tobacco was infiltrated with cultures of $A$. tumefaciens transformed with plasmid pGTEV $\triangle$ NIb-CVB and also, as controls, with $A$. tumefaciens transformed with pGTEV (wildtype virus, TEV-wt), pGTEV $\triangle$ NIb-Cherry, pGTEV $\Delta$ NIb-Venus and pGTEV $\Delta$ NIb-Blue (defective viruses with cassettes to express single reporter proteins, Fig. S1). At 4 days postinoculation (dpi) in plants agroinoculated with TEV-wt and with the defective viruses TEV $\Delta$ NIb-Cherry, TEV $\Delta$ NIb-Venus and TEV $\Delta$ NIb-Blue, the typical 
TEV etching symptoms emerged. Milder symptoms emerged in plants agroinoculated with TEV $\triangle$ NIb-CVB with a delay of a few days. Microscopic examination of systemic leaves from plants infected by TEV $\Delta$ NIb-Cherry, TEV $\Delta$ NIb-Venus and TEV $\Delta$ NIb-Blue revealed intense red, green (instead of yellow due to the stereomicroscope filter) and blue fluorescence, respectively, while leaves from plants infected by TEV $\triangle$ NIb-CVB showed the three fluorescent signals fully colocalized, as can be seen in the set of leaves collected at 9 dpi shown in Fig. 2a. A more precise analysis with a confocal microscope showed a full colocalization of the three fluorescence signals at the subcellular level (Fig. 2b). All three proteins accumulated throughout the cytoplasm and nucleus of the infected cells.

Wild-type $N$. benthamiana plants were coinfiltrated with a 1:1 mix of two cultures of $A$. tumefaciens transformed with either plasmid pgR107-NIb, which induces an infection by PVX-NIb, or with pGTEVANIb-CVB. Controls included inoculation of PVX-NIb alone and co-inoculation of PVX-NIb with TEV-wt, TEV $\Delta$ NIb-Cherry, TEV $\Delta$ NIb-Venus or TEV $\Delta$ NIbBlue. At $4 \mathrm{dpi}$, the apical leaves of the plants coagroinoculated with both PVX-NIb and TEV-wt became symptomatic (curling). With a delay of a few days, much milder symptoms (chlorotic spots) could be observed in plants coagroinoculated with PVX-NIb and TEV $\Delta$ NIb-Cherry, TEV $\Delta$ NIb-Venus or TEV $\Delta$ NIb-Blue. Plants agroinoculated with PVX-NIb alone or the mix PVX-NIb/TEVANIb-CVB were even slower to show symptoms and these were milder yet. About $14 \mathrm{dpi}, N$. benthamiana plants coagroinoculated with both PVX-NIb and TEV-wt collapsed. The remaining plants only showed mild symptoms. As in other experiments, symptomatic tissue was collected at different dpi and the expression of the fluorescent proteins microscopically analyzed. The results were somewhat similar to the case of the transgenic tobacco. Systemic leaves of plants coagroinoculated with PVX-NIb and TEVANIb-Cherry, TEVANIb-Venus or TEV $\Delta$ NIbBlue showed the corresponding fluorescence signals at 9 dpi (Fig. 2c). However, in this case, the reporter fluorescent proteins were never detected in systemic leaves of plants coagroinoculated with PVX-NIb and TEVANIb-CVB (Fig. 2c). 

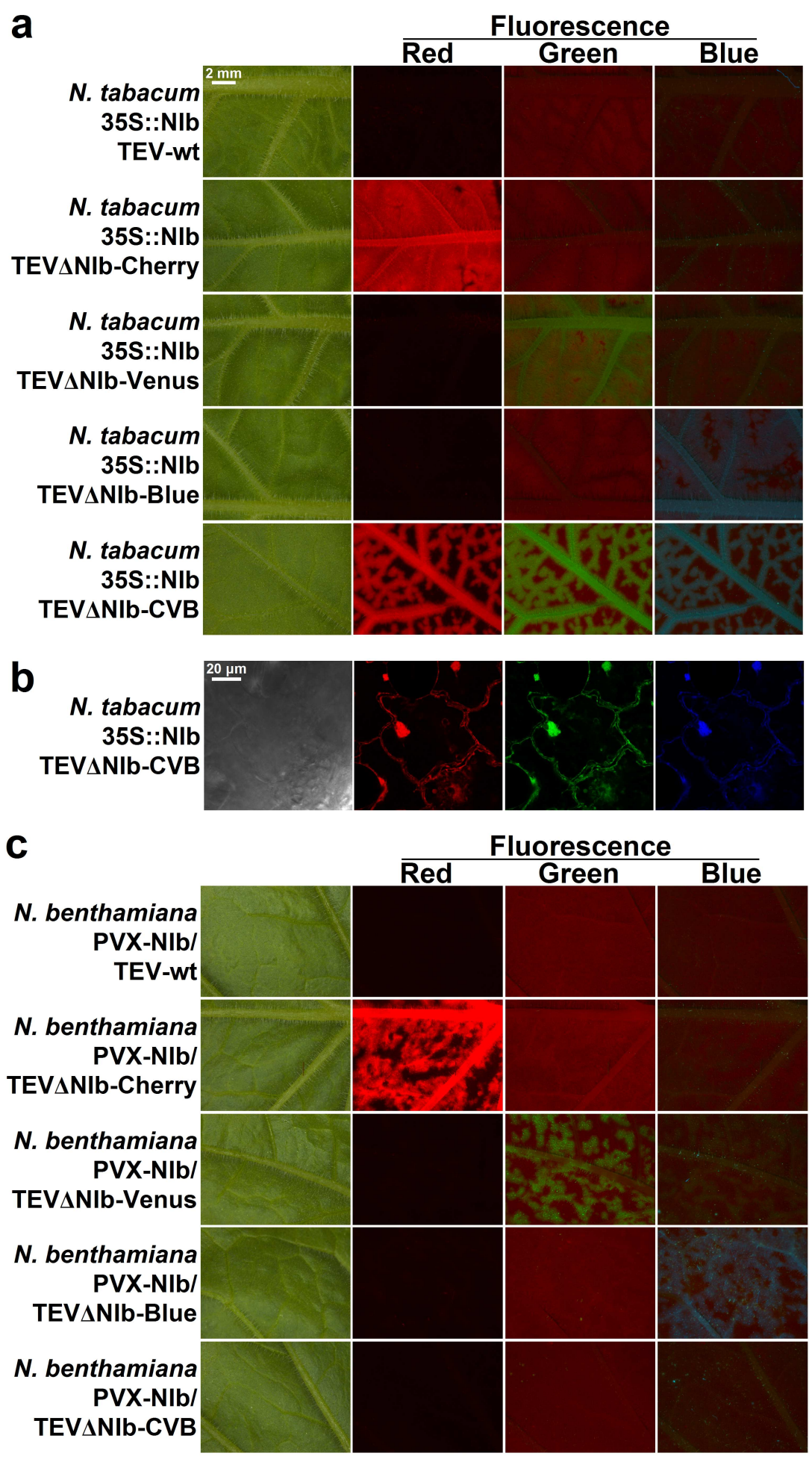

Fig. 2. Expression of the fluorescent reporter proteins. (a) Fluorescence stereomicroscope images of leaves of $N$. tabacum 35S::NIb inoculated with TEV-wt, TEV $\Delta \mathrm{Nlb}$-Cherry, TEV $\Delta \mathrm{NIb}$ Venus, TEV $\triangle \mathrm{Nlb}$-Blue and TEV $\triangle \mathrm{NIb}-\mathrm{CVB}$ taken with filters to detect red, green and blue fluorescence. (b) Confocal microscope images of a leaf of $N$. tabacum 35S::NIb inoculated with TEV $\triangle \mathrm{NIb}-\mathrm{CVB}$ with a combination of excitation lasers and detection windows to detect blue, green and red fluorescence. (c) Fluorescence stereomicroscope images of leaves of wild-type $N$. benthamiana plants coinoculated with PVX-NIb and TEV-wt, TEV $\Delta$ NIb-Cherry, TEV $\Delta$ NIbVenus, TEV $\triangle$ Nlb-Blue or TEV $\Delta$ Nlb-CVB taken with filters to detect red, green and blue fluorescence. Scale bars $2 \mathrm{~mm}$ (a and c) and $20 \mu \mathrm{m}(\mathrm{b})$. 


\subsection{Processing of the reporter fluorescent proteins from the viral polyprotein}

Next, the processing of the three reporter fluorescent proteins from the TEV $\triangle \mathrm{NIb}-\mathrm{CVB}$ polyprotein was investigated in symptomatic systemic tissue from transgenic tobaccos infected with TEV $\triangle \mathrm{NIb}-\mathrm{CVB}$, as well as from wild-type $N$. benthamiana plants coinfected with PVX-Nlb/TEVANIb-CVB. Tissue was collected at several time points, along with tissue from controls consisting of transgenic tobacco infected with TEV-wt, TEV $\triangle \mathrm{Nlb}$ Cherry, TEV $\Delta$ NIb-Venus and TEV $\Delta$ NIb-Blue and wild-type $N$. benthamiana plants coinfected with PVX-Nlb and TEV-wt, TEVANlb-Cherry, TEV $\Delta \mathrm{Nlb}$-Venus or TEV $\Delta \mathrm{Nlb}$ Blue. Proteins were extracted and separated by SDS-PAGE and the red (FLAGmCherry), yellow (HAVenus) and blue (c-Myc-mTagBFP) fluorescent proteins detected by western blot analysis using anti-FLAG, anti-HA and anti-c-Myc antibodies, respectively. Fig. 3 shows a representative experiment with tissues collected at $9 \mathrm{dpi}$. All expressed proteins could be detected by the corresponding antibodies and exclusively in their mature form, demonstrating the very efficient release of the heterologous proteins from the viral polyprotein. No protein was detected in wild-type $N$. benthamiana plants coagroinoculated with PVX-Nlb and TEVANIb-CVB (Fig. 3a-c, lanes 10), consistent with the observation under the fluorescence stereomicroscope and confirming that PVX-Nlb is unable to rescue the defective virus TEV $\triangle \mathrm{Nlb}-\mathrm{CVB}$ in the experimental conditions used here.

\subsection{Infectivity, expression level and stability of the defective TEV viral vector}

The inability of the defective viruses (TEV $\triangle \mathrm{Nlb}-\mathrm{CVB}$, TEV $\Delta \mathrm{Nlb}$ - Cherry, TEV $\Delta$ NlbVenus and TEVANlb-Blue) to infect plants where the viral Nlb was not present was confirmed y agroinoculation of wild-type and transgenic tobacco. After agroinoculation, all viruses induced etching symptoms a few dpi in transgenic tobacco but only the TEVwt control did so in wild-type tobacco. The results were confirmed molecularly by RTPCR diagnosis using systemic tissue collected at $30 \mathrm{dpi}$ from three replicate plants per treatment. Fig. 4 shows representative results from one of the three sets of inoculated plants. A 790-bp specific cDNA corresponding to coat protein TEV cistron was amplified from wild-type tobacco plants inoculated with TEV-wt but not from those inoculated with the defective viruses (Fig. 4, compare lane 2 with 3-6). The specific product was amplified from transgenic tobacco plants in all cases (Fig. 4, lanes 8-12). These results 
corroborate that the defective viral vector is only infectious in TEV NIb expressing tobacco, and noninfectious to wild-type tobacco.

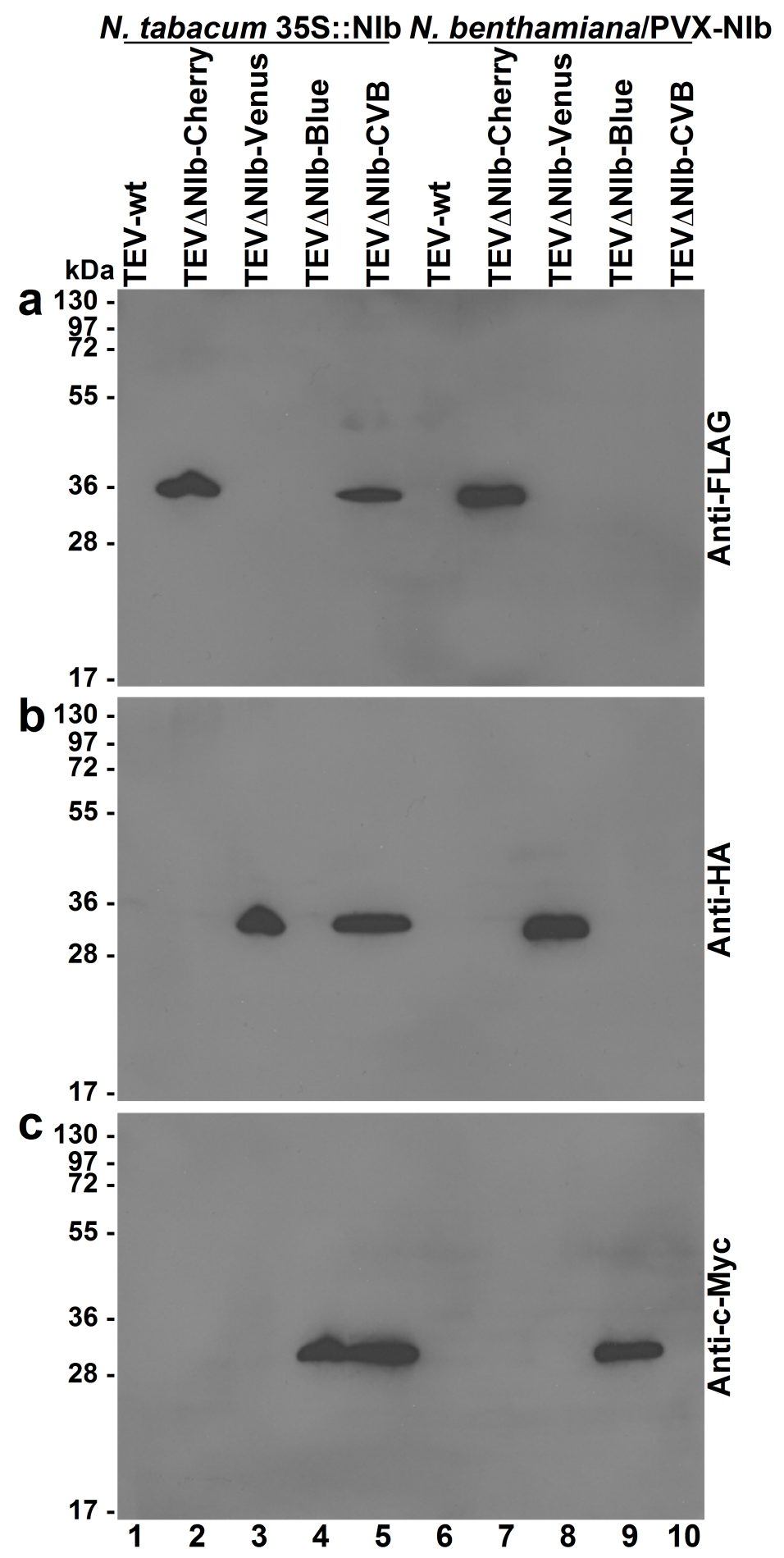

Fig. 3. Western blot analysis of the heterologous proteins expressed in $N$. tabacum $35 \mathrm{~S}: \mathrm{NIb}$ and $N$. benthamiana/PVX-NIb from vectors TEV $\Delta$ Nlb-Cherry, TEV $\Delta N I b$ - Venus, TEV $\Delta N I b-B l u e$ and TEV $\triangle$ NIb-CVB. Proteins were separated by SDS-PAGE, blotted and detected with antiFLAG (a), anti-HA (b) and anti-c-Myc (c) antibodies. N. tabacum 35S::NIb (lanes 1-5) and N. benthamiana/PVX-Nlb (lanes 6-10) inoculated with TEV-wt (lanes 1 and 6), TEV $\Delta$ Nlb-Cherry (lanes 2 and 7), TEV $\Delta$ Nlb-Venus (lanes 3 and 8), TEV $\Delta$ NIb-Blue (lanes 4 and 9) and TEV $\Delta$ NIbCVB (lanes 5 and 10). The positions and masses (in $\mathrm{kDa}$ ) of protein markers are indicated on the left. 


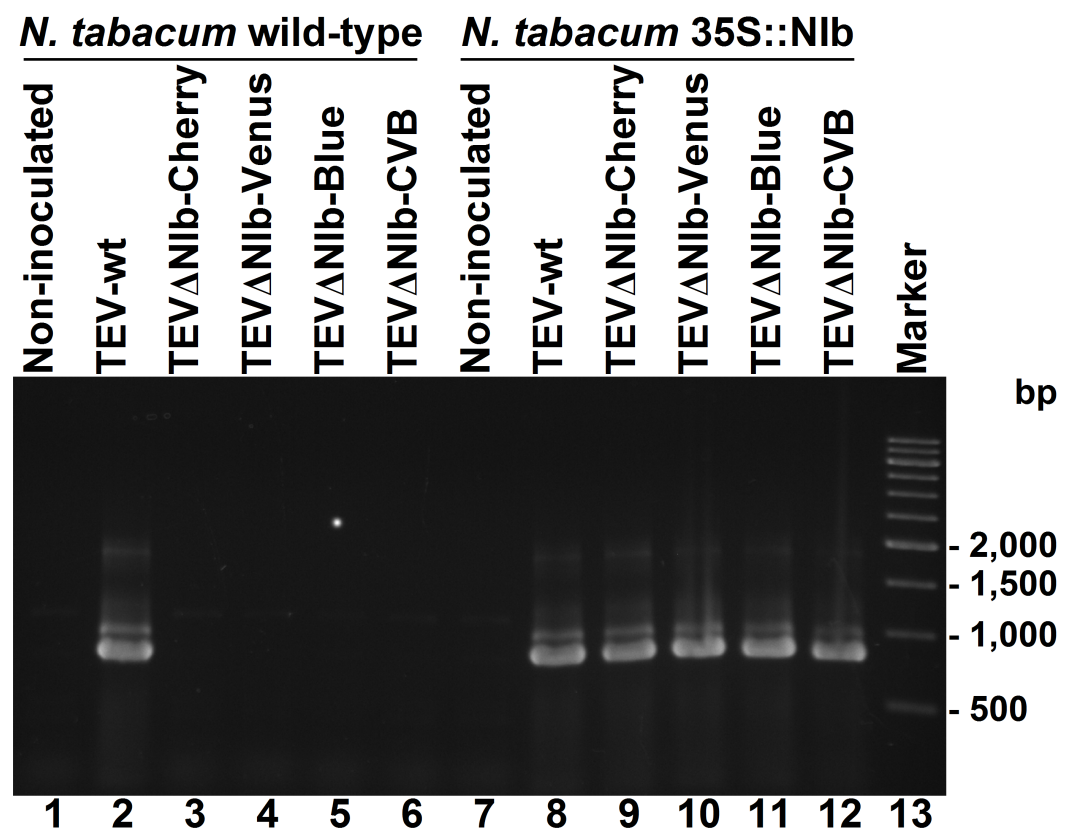

Fig. 4. TEV diagnosis by RT-PCR at 30 dpi in wild-type and $35 \mathrm{~S}:: \mathrm{Nlb} N$. tabacum inoculated with the defective viruses TEV $\triangle \mathrm{Nlb}$-Cherry, TEV $\Delta$ NIb-Venus, TEV $\Delta \mathrm{Nlb}-\mathrm{Blue}$ and TEV $\Delta \mathrm{NIb}-$ CVB. Amplification products were separated by electrophoresis in an agarose gel stained with ethidium bromide. Wild-type $N$. tabacum (lanes 1-6) and N. tabacum 35S::NIb (lanes 7-12) non-inoculated (lanes 1 and 7) or inoculated with TEV-wt (lanes 2 and 8), TEV $\Delta$ NIb-Cherry (lanes 3 and 9), TEV $\Delta$ NIb-Venus (lanes 4 and 10), TEV $\Delta$ NIb-Blue (lanes 5 and 11) and TEV $\Delta$ NIb-CVB (lanes 6 and 12). Lane 13, 500-bp ladder DNA marker with the length of some components (in bp) indicated on the right.

The heterologous protein yield resulting from infection with the defective vectors was also investigated. First, the expression of the three fluorescent proteins was screened in all leaves of plants infected by TEV $\Delta$ NIb-CVB. Strong coexpression of the three proteins was microscopically observed at $14 \mathrm{dpi}$ in most of the leaves above the two agroinoculated (Fig. S2). Second, the amount of the heterologous proteins expressed through the defective viral vector was estimated. For this purpose, FLAG-mCherry, in the form in which is released from the TEV $\triangle \mathrm{NIb}-\mathrm{CVB}$ polyprotein plus an additional amino terminal Met and a carboxy terminal Leu-Glu-His6 tail, was expressed in E. coli and purified by chromatography using a Ni-Sepharose column in denaturing conditions. The purified protein was quantified by SDS-PAGE separation and blue Coomassie staining using standards of bovine serum albumin of known concentration. Once quantified, dilutions of the FLAGmCherry preparation were used to estimate the amount of protein accumulating in the infected tissues by SDS-PAGE separation and western blot analysis using the anti-FLAG antibody (Fig. 5). At 9 dpi, symptomatic tissue had accumulated $8 \mathrm{mg}$ of FLAG-mCherry per $\mathrm{kg}$ of symptomatic tissue in transgenic tobacco infected by TEV $\triangle \mathrm{Nlb}-\mathrm{CVB}, 17 \mathrm{mg} / \mathrm{kg}$ for transgenic tobacco infected by 
TEV $\Delta \mathrm{Nlb}$-Cherry, and $20 \mathrm{mg} / \mathrm{kg}$ for wild-type $\mathrm{N}$. benthamiana coinfected by PVX-Nlb and TEV $\Delta \mathrm{Nlb}$-Cherry.

The stability of the expression vector was examined by RT-PCR amplification of the expression cassette at the end of an infectious cycle and by inoculation of a second set of plants using sap from leaves collected at $11 \mathrm{dpi}$. Only the full-length cassette was amplified at $11 \mathrm{dpi}$ from transgenic tobacco infected with TEV $\Delta \mathrm{Nlb}$-Cherry, TEV $\Delta \mathrm{Nlb}$ Venus and TEVANlb-Blue (Fig. 6, lanes 3-5). However in plants infected with TEV $\triangle$ NIb-CVB some smaller products were amplified in addition to the full-length cassette (Fig. 6, lane 6), suggesting the occurrence of some recombination events during virus replication in this case. Consistent with these observations, transgenic tobaccos infected with sap collected at $11 \mathrm{dpi}$ from plants previously infected with TEV $\Delta$ NIb-Cherry, TEVANIb-Venus, TEVANIb-Blue and TEVANIb-CVB also showed the expression of the corresponding fluorescent proteins (Fig. S3).

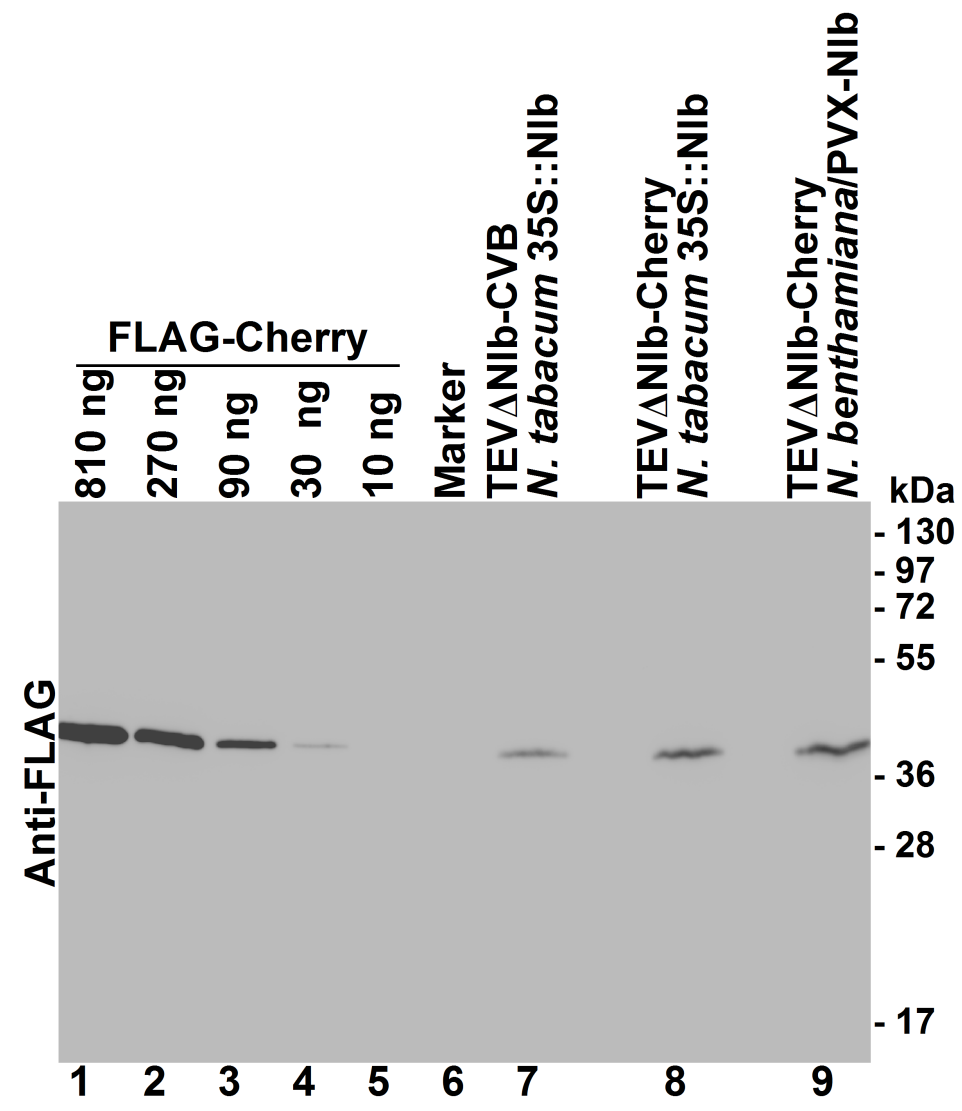

Fig. 5. Quantification of heterologous protein FLAG-mCherry expressed in N. tabacum 35S::NIb and $N$. benthamiana/PVX-NIb through the defective viral vectors TEV $\Delta$ NIb-Cherry and TEV $\triangle$ NIb-CVB. Proteins were separated by SDS-PAGE in duplicated gels, one stained with Coomassie blue (not shown) and the other subjected to western blot analysis using an antiFLAG antibody. Lanes 1-5, FLAG-mCherry standards purified from E. coli. Lane 6, protein molecular mass marker with positions and masses (in $\mathrm{kDa}$ ) indicated on the right. Lanes 7 and 8, N. tabacum 35S::NIb inoculated with TEV $\Delta$ NIb-CVB and TEV $\Delta$ Nlb-Cherry, respectively (6.7 $\mathrm{mg}$ fresh weight tissue). Lane 9, N. benthamiana/PVX-NIb inoculated with TEV $\Delta$ NIb-Cherry (6.7 mg fresh tissue). 


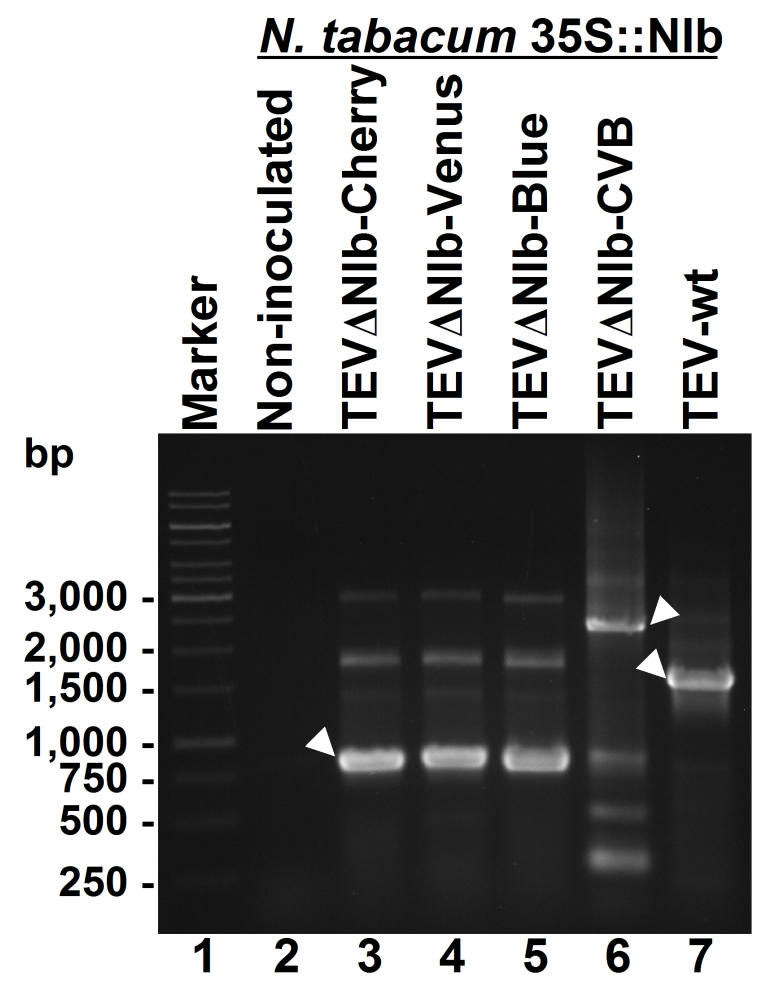

Fig. 6. Analysis by RT-PCR of the stability at $11 \mathrm{dpi}$ of the expression cassette in the defective viral vectors TEV $\Delta$ Nlb-Cherry, TEVANIb-Venus, TEV $\Delta$ NIb-Blue and TEV $\Delta$ NIb-CVB. Amplification products were separated by electrophoresis in an agarose gel that was stained with ethidium bromide. Lane 1, ladder DNA marker with the length of some components (in bp) indicated on the left. $N$. tabacum 35S::NIb non-inoculated (lane 2) or inoculated with TEV $\Delta \mathrm{NIb}$ Cherry (lane 3), TEV $\Delta \mathrm{NIb}$-Venus (lane 4), TEV $\Delta \mathrm{NIb}$-Blue (lane 5), TEV $\Delta \mathrm{NIb}-\mathrm{CVB}$ (lane 6) and TEV-wt (lane 7). The amplification products corresponding to the different full-length expression cassettes are indicated by arrowheads.

3.4. Coexpression of two transcription factors involved in the anthocyanin biosynthesis pathway

To demonstrate the utility of the new expression vector in plant metabolic engineering, the transcription factors Delila and Rosea1 from $A$. majus were coexpressed. These transcription factors are known to physically interact to activate the biosynthesis of anthocyanins. Transgenic tobacco plants were infiltrated with a culture of $A$. tumefaciens transformed with plasmid pGTEVANIb-DelRos (Fig. S4). Inoculated plants started to show the typical etching symptoms of TEV at 5 dpi. With a delay of 1 day, the etching pattern started to dye dark red. During the following days the dark red color expanded covering the symptomatic leaves, as can be seen in the set of leaves collected at 9 dpi shown in Fig. 7. 


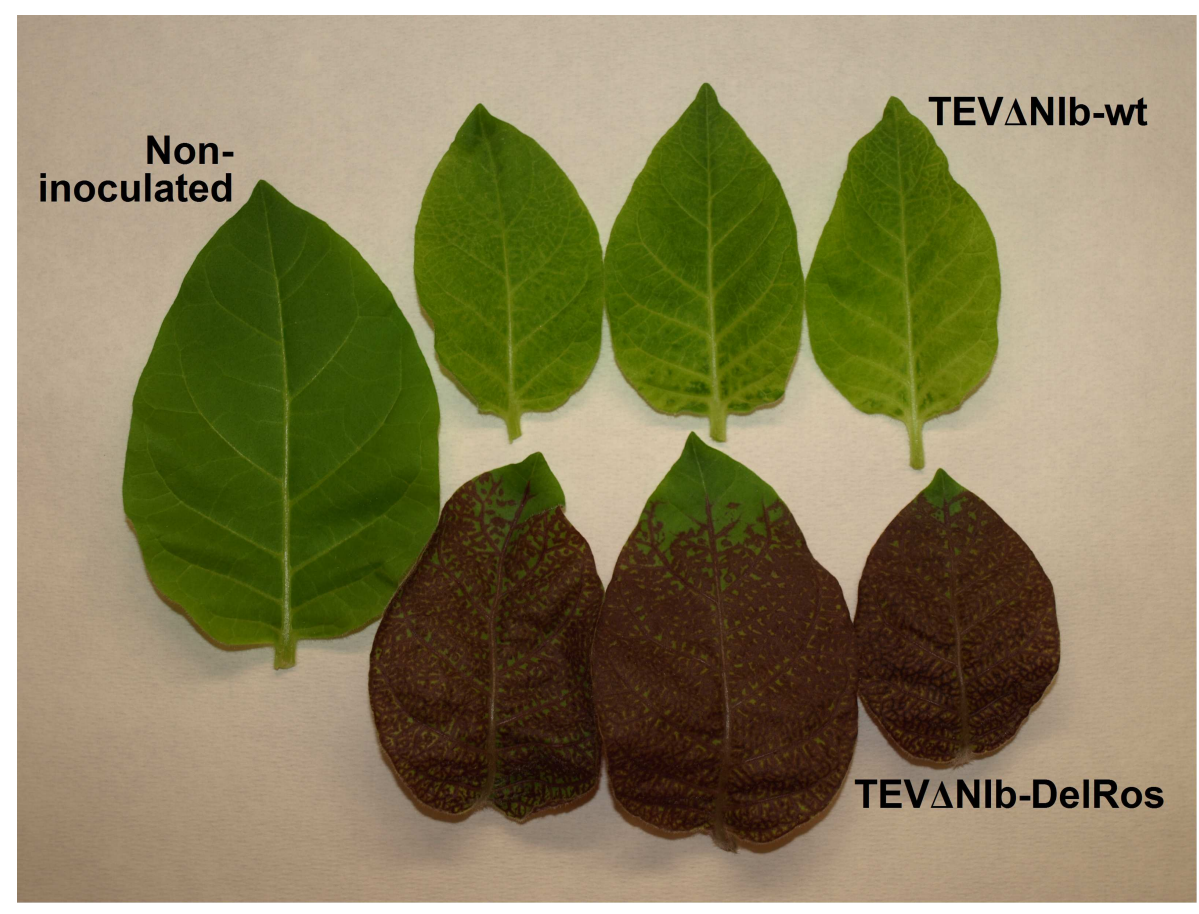

Fig. 7. Expression of $A$. majus Delila and Rosea1 transcription factors in N. tabacum 35S::NIb. Systemic symptomatic leaves from three Nlb-expressing transgenic tobaccos inoculated with TEV $\Delta$ NIb-wt and TEV $\Delta$ NIb-DelRos. A comparable leaf from a non-inoculated control is also included.

\section{Discussion}

The use of plants as biofactories has advantages such as low production cost, ease of scaling production, improbability of contamination with human pathogens, the rich and diverse metabolism of plants and a posttranslational modification system similar to that of mammalian cells (Liénard et al., 2007; Shih and Doran, 2009). The use of viruses as expression vectors in plants adds production speed and the intrinsic capacity of plant viruses to manipulate host genetic expression to boost production of viral proteins, for example, through the activity of the viral suppressors of RNA silencing ( $\mathrm{Li}$ and Ding, 2006). The new viral expression vector presented here is engineered from a potyvirus infectious clone and allows simultaneous coexpression of equimolar amounts of several heterologous proteins in the same subcellular location. Consequently, this new vector could facilitate coexpression of the polypeptide components of heterooligomeric proteins requiring accurate assembly or the several proteins comprising or regulating a metabolic pathway whose enzymes must act coordinately. When the NIb cistron of the infectious TEV cDNA contained in pGTEV (Bedoya and Darós, 2010) was replaced by a cassette to coexpress three reporter proteins (Figs. 1 and Fig. S1), the resulting virus infected and moved systemically in transgenic tobacco plants expressing the viral NIb. 
Moreover, the viral vector was stable during infection (Figs. 6 and Fig. S3) and produced the three fluorescent reporter proteins fully colocalized throughout the infected leaves (Figs. 2 and Fig. S2). The heterologous proteins were efficiently processed from the viral polyprotein (Fig. 3). Logically, the viral vector was unable to infect plants were the viral RNA polymerase was not provided in trans (Fig. 4). Provision of NIb from a transgene was more effective than coinoculation with PVX-NIb, because in the latter system only viral vectors expressing a single heterologous protein were supported (Figs. 2 and 3). The discrepancy in trans-complementation efficiency could be related to differences in the amount or location of Nlb produced by these two strategies.

Potyviruses have previously been used as vectors to express heterologous proteins in plants (Dolja et al., 1992; Carrington et al., 1993; Guo et al., 1998; German-Retana et al., 2000; Choi et al., 2000). Products such as soybean glutamine synthetase (Masuta et al., 2000), the VP60 structural protein of rabbit hemorrhagic disease virus (Fernández-Fernández et al., 2001), the Momordica and Gelonium anti-HIV proteins (Arazi et al., 2002) or the dust mite Dermatophagoides pteronyssinus group 5 allergen (Hsu et al., 2004) have been successfully expressed. Their genetic expression strategy, a polyprotein processed by viral proteases, allows these viruses to be used to tackle a classic limitation of viral vectors: coexpression of equimolar amounts of several heterologous proteins (Sainsbury et al., 2008). Using potyvirus based vectors, two (Masuta et al., 2000; Beauchemin et al., 2005) and up to three different heterologous proteins (Kelloniemi et al., 2008) have been expressed. The encapsidation of the potyvirus genomic RNA in an elongated virion facilitates insertion of large amounts of heterologous genetic information. In fact, a vector based on potyvirus potato virus $A$ that expressed three heterologous proteins had a genome $39.2 \%$ larger and was infectious, stable and moved systemically in infected plants (Kelloniemi et al., 2008). The vector described here could likely accommodate substantially larger insertions due to the initial $1.5-\mathrm{kb}$ deletion in the viral genome. The insertion of a 2.66- kb expression cassette only increases genome size $11 \%$ (Fig. S4). The expression of multiple proteins in potyviruses has previously been tackled in two different ways: introducing each protein in a different position in the viral polyprotein (Kelloniemi et al., 2008) or in a single expression cassette (Masuta et al., 2000). The processing of the heterologous proteins from the viral polyprotein is mediated by the viral proteases, that are functional in trans, acting on natural or artificial proteolytic sites (Carrington et al., 1993). In the expression vector described in this work, the three heterologous proteins were released from the 
polyprotein by the activity of the viral protease NlaPro (or its unprocessed version NIa) cleaving two natural (NlaPro/NIb and NIb/CP) and two artificial proteolytic sites. It is well known that TEV NlaPro specifically cleaves the heptapeptide Glu-X-X-Tyr-X-GIn/(Ser or Gly) (Dougherty et al., 1988; Phan et al., 2002). However, due to a bias in positions P2' and P3' in NlaPro cleavage motifs in all known potyvirus species (Adams et al., 2005), the eleven amino acids (TTENLYFQ/SGT,-8/+3) surrounding the natural TEV NIb/CP proteolytic site were chosen to construct the expression cassette, which resulted in a very efficient processing of the polyprotein (Fig. 3). The yield of the heterologous proteins expressed from the defective vector will require further investigation, because it may depend on many factors including the host plant species, harvest time, growth conditions or which part of the plant is analyzed. Yield might be further improved through codon optimization or by the inclusion of tags to induce specific subcellular localization or posttranslational modifications, improve protein stability or facilitate purification of the heterologous proteins (Streatfield, 2007). The yield of 8-20 mg per kg of infected tissue obtained in the present work (Fig. 5) is modest when compared to some other plant virus based expression systems which allow production of grams of heterologous protein per kg of tissue (Marillonnet et al., 2005; Lindbo, 2007; Sainsbury and Lomonossoff, 2008). However, these yields are comparable or even higher than those reported for similar proteins with other potyvirus-based vectors (Hsu et al., 2004; Shih and Doran, 2009). Nonetheless, these amounts of several proteins when expressed stoichiometrically in the same subcellular location may be sufficient for some purposes, as exemplified here by the coexpression of the two transcription factors Delila and Rosea1 that physically interact to induce anthocyanin biosynthesis in $A$. majus flowers (Schwinn et al., 2006; Butelli et al., 2008; Orzaez et al., 2009). These two transcription factors activate almost all genes encoding anthocyanin biosynthetic enzymes, including genes required for side chain modification and two genes involved in vacuolar import. Their coexpression through the TEV $\Delta$ NIb vector in NIb-expressing tobacco plants was sufficient to turn infected leaves dark red (Fig. 7). Some limitations of the expression system here described are that the heterologous proteins released from the TEV polyprotein contain extraneous amino acids at their amino and carboxy termini coming from the NlaPro proteolysis motif and that the heterologous proteins might be unable to enter secretory pathways to undergo posttranslational modification once released from the viral polyprotein. 
Finally, the defective viral vector only infects plants where the NIb activity from TEV is supplied in trans (Fig. 4). This may be perceived as an additional limitation, because the approach is bound either to a transgenic plant or to a coexpressing viral vector. From a biosecurity perspective, however, it is a major advantage because simultaneous transmission of both the viral vector and particularly a Nlb-expressing transgene to a non-target plant is exceedingly unlikely. As with other deconstructed viral vectors (Marillonnet et al., 2005; Regnard et al., 2010), the absence of intrinsic infectivity makes this vector more biosecure, diminishing the risk of escape to environment.

\section{Acknowledgements}

This work has been partially supported by grants BIO2008-01986 from Ministerio de Ciencia e Innovación from Spain and ACOMP/2009/042 from Generalitat Valenciana to J.A.D. F.M. is the recipient of a predoctoral fellowship from Universidad Politécnica de Valencia. We are in debt to Dr. James C. Carrington (Oregon State University) for providing Nlb expressing transgenic tobacco plants and to Dr. Diego Orzáez for advice and providing Delila/Rosea1 expressing tomato tissue. We thank Dr. C. Douglas Grubb (Leibniz-Institut für Pflanzenbiochemie, Germany) and Dr. Mark Zwart (IBMCP, Valencia) for critical review of the manuscript, and Dr. María Burgal and Dr. Alberto Hernández (Centro de Investigación Príncipe Felipe, Valencia) for valuable assistance with confocal microscope analysis.

\section{References}

Adams, M.J., Antoniw, J.F., Beaudoin, F., 2005. Overview and analysis of the olyprotein cleavage sites in the family Potyviridae. Mol. Plant Pathol. 6, 471-487.

Arazi, T., Huang, P.L., Huang, P.L., Zhang, L., Shiboleth, Y.M., Gal-On, A., Lee-Huang, S., 2002. Production of antiviral and antitumor proteins MAP30 and GAP31 in cucurbits using the plant virus vector ZYMV-AGII. Biochem. Biophys. Res. Commun. 292, 441-448.

Beauchemin, C., Bougie, V., Laliberté, J.F., 2005. Simultaneous production of two foreign proteins from a polyvirus-based vector. Virus Res. 112, 1-8.

Bedoya, L.C., Daròs, J.A., 2010. Stability of Tobacco etch virus infectious clones in plasmid vectors. Virus Res. 149, 234-240. 
Butelli, E., Titta, L., Giorgio, M., Mock, H.P., Matros, A., Peterek, S., Schijlen, E.G., Hall, R.D., Bovy, A.G., Luo, J., Martin, C., 2008. Enrichment of tomato fruit with healthpromoting anthocyanins by expression of select transcription factors. Nat. Biotechnol. 26, 1301-1308.

Cañizares, M.C., Nicholson, L., Lomonossoff, G.P., 2005. Use of viral vectors for vaccine production in plants. Immunol. Cell Biol. 83, 263-270.

Carrington, J.C., Haldeman, R., Dolja, V.V., Restrepo-Hartwig, M.A., 1993. Internal cleavage and trans-proteolytic activities of the VPg-proteinase (NIa) of tobacco etch potyvirus in vivo. J. Virol. 67, 6995-7000.

Choi, I.R., Stenger, D.C., Morris, T.J., French, R., 2000. A plant virus vector for systemic expression of foreign genes in cereals. Plant J. 23, 547-555.

Chung, B.Y.W., Miller, W.A., Atkins, J.F., Firth, A.E., 2008. An overlapping essential gene in the Potyviridae. Proc. Natl. Acad. Sci. U.S.A. 105, 5897-5902.

Dolja, V.V., McBride, H.J., Carrington, J.C., 1992. Tagging of plant potyvirus replication and movement by insertion of $\beta$-glucuronidase into the viral polyprotein. Proc. Natl. Acad. Sci. U.S.A. 89, 10208-10212.

Dougherty, W.G., Carrington, J.C., Cary, S.M., Parks, T.D., 1988. Biochemical and mutational analysis of a plant virus polyprotein cleavage site. EMBO J. 7, 12811287.

Fauquet, C.M., Mayo, M.A., Maniloff, J., Desselberger, U., Ball, L.A. (Eds.), 2005. Virus Taxonomy. Eight Report of the International Committee on Taxonomyof Viruses. Elsevier/Academic Press, London.

Fernández-Fernández, M.R., Mouriño, M., Rivera, J., Rodríguez, F., Plana-Durán, J., García, J.A., 2001. Protection of rabbits against rabbit hemorrhagic disease virus by immunization with the VP60 protein expressed in plants with a potyvirus-based vector. Virology 280, 283-291.

German-Retana, S., Candresse, T., Alias, E., Delbos, R.P., Le Gall, O., 2000. Effects of green fluorescent protein or $\beta$-glucuronidase tagging on the accumulation and pathogenicity of a resistance-breaking Lettuce mosaic virus isolate in susceptible and resistant lettuce cultivars. Mol. Plant Microbe Interact. 13, 316-324.

Gleba, Y., Klimyuk, V., Marillonnet, S., 2007. Viral vectors for the expression of proteins in plants. Curr. Opin. Biotechnol. 18, 134-141. 
Guo, H.S., López-Moya, J.J., García, J.A., 1998. Susceptibility to recombination rearrangements of a chimeric plum pox potyvirus genome after insertion of a foreign gene. Virus Res. 57, 183-195.

Hsu, C.H., Lin, S.S., Liu, F.L., Su, W.C., Yeh, S.D., 2004. Oral administration of a mite allergen expressed by zucchini yellow mosaic virus in cucurbit species downregulates allergen-induced airway inflammation and $\lg \mathrm{E}$ synthesis. J. Allergy Clin. Immunol. 113, 1079-1085.

Kelloniemi, J., Mäkinen, K., Valkonen, J.P., 2008. Three heterologous proteins simultaneously expressed from a chimeric potyvirus: infectivity, stability and the correlation of genome and virion lengths. Virus Res. 135, 282-291.

Li, F., Ding, S.W., 2006. Virus counterdefense: diverse strategies for evading the RNAsilencing immunity. Annu. Rev. Microbiol. 60, 503-531.

Li, X.H., Carrington, J.C., 1995. Complementation of tobacco etch potyvirus mutants by active RNA polymerase expressed in transgenic cells. Proc. Natl. Acad. Sci. U.S.A. 92, 457-461.

Lico, C., Chen, Q., Santi, L., 2008. Viral vectors for production of recombinant proteins in plants. J. Cell. Physiol. 216, 366-377.

Liénard, D., Sourrouille, C., Gomord, V., Faye, L., 2007. Pharming and transgenic plants. Biotechnol. Annu. Rev. 13, 115-147.

Lindbo, J.A., 2007. TRBO: a high-efficiency tobacco mosaic virus RNA-based overexpression vector. Plant Physiol. 145, 1232-1240.

Lu, R., Malcuit, I., Moffett, P., Ruiz, M.T., Peart, J., Wu, A.J., Rathjen, J.P., Bendahmane, A., Day, L., Baulcombe, D.C., 2003. High throughput virus-induced gene silencing implicates heat shock protein 90 in plant disease resistance. EMBO J. 22, 5690-5699.

Marillonnet, S., Thoeringer, C., Kandzia, R., Klimyuk, V., Gleba, Y., 2005. Systemic Agrobacterium tumefaciens-mediated transfection of viral replicons for efficient transient expression in plants. Nat. Biotechnol. 23, 718-723.

Masuta, C., Yamana, T., Tacahashi, Y., Uyeda, I., Sato, M., Ueda, S., Matsumura, T., 2000. Development of clover yellow vein virus as an efficient, stable geneexpression system for legume species. Plant J. 23, 539-546.

Nagai, T., Ibata, K., Park, E.S., Kubota, M., Mikoshiba, K., Miyawaki, A., 2002. A variant of yellow fluorescent protein with fast and efficient maturation for cell-biological applications. Nat. Biotechnol. 20, 87-90. 
Orzaez, D., Medina, A., Torre, S., Fernández-Moreno, J.P., Rambla, J.L., Fernándezdel-Carmen, A., Butelli, E., Martin, C., Granell, A., 2009. A visual reporter system for virus-induced gene silencing in tomato fruit based on anthocyanin accumulation. Plant Physiol. 150, 1122-1134.

Phan, J., Zdanov, A., Evdokimov, A.G., Tropea, J.E., Peters III, H.K., Kapust, R.B., Li, M., Wlodawer, A., Waugh, D.S., 2002. Structural basis for the substrate specificity of tobacco etch virus protease. J. Biol. Chem. 277, 50564-50572.

Pogue, G.P., Lindbo, J.A., Garger, S.J., Fitzmaurice, W.P., 2002. Making an ally from an enemy: plant virology and the new agriculture. Annu. Rev. Phytopathol. 40, 4574.

Regnard, G.L., Halley-Stott, R.P., Tanzer, F.L., Hitzeroth, I.I., Rybicki, E.P., 2010. High level protein expression in plants through the use of a novel autonomously replicating geminivirus shuttle vector. Plant Biotechnol. J. 8, 38-46.

Sainsbury, F., Cañizares, M.C., Lomonossoff, G.P., 2010. Cowpea mosaic virus: the plant virus-based biotechnology workhorse. Annu. Rev. Phytopathol..

Sainsbury, F., Lavoie, P.O., D’Aoust, M.A., Vézina, L.P., Lomonossoff, G.P., 2008. Expression of multiple proteins using full-length and deleted versions of cowpea mosaic virus RNA-2. Plant Biotechnol. J. 6, 82-92.

Sainsbury, F., Lomonossoff, G.P., 2008. Extremely high-level and rapid transient protein production in plants without the use of viral replication. Plant Physiol. 148, 12121218.

Schwinn, K., Venail, J., Shang, Y., Mackay, S., Alm, V., Butelli, E., Oyama, R., Bailey, P., Davies, K., Martin, C., 2006. A small family of MYB-regulatory genes controls floral pigmentation intensity and patterning in the genus Antirrhinum. Plant Cell 18, 831-851.

Shaner, N.C., Campbell, R.E., Steinbach, P.A., Giepmans, B.N., Palmer, A.E., Tsien, R.Y., 2004. Improved monomeric red, orange and yellow fluorescent proteins derived from Discosoma sp. red fluorescent protein. Nat. Biotechnol. 22, 15671572.

Shih, S.M., Doran, P.M., 2009. Foreign protein production using plant cell and organ cultures: advantages and limitations. Biotechnol. Adv. 27, 1036-1042.

Streatfield, S.J., 2007. Approaches to achieve high-level heterologous protein production in plants. Plant Biotechnol. J. 5, 2-15. 
Subach, O.M., Gundorov, I.S., Yoshimura, M., Subach, F.V., Zhang, J., Grüenwald, D., Souslova, E.A., Chudakov, D.M., Verkhusha, V.V., 2008. Conversion of red fluorescent protein into a bright blue probe. Chem. Biol. 15, 1116-1124.

Thole, V., Worland, B., Snape, J.W., Vain, P., 2007. The pCLEAN dual binary vector system for Agrobacterium-mediated plant transformation. Plant Physiol. 145, 12111219.

Urcuqui-Inchima, S., Haenni, A.L., Bernardi, F., 2001. Potyvirus proteins: a wealth of functions. Virus Res. 74, 157-175.

Wei, T., Zhang, C., Hong, J., Xiong, R., Kasschau, K.D., Zhou, X., Carrington, J.C., Wang, A., 2010. Formation of complexes at plasmodesmata for potyvirus intercellular movement is mediated by the viral protein P3N-PIPO. PLoS Pathog. 6, e1000962.

Zhong, S., Lin, Z., Fray, R.G., Grierson, D., 2008. Improved plant transformation vectors for fluorescent protein tagging. Transgenic Res. 17, 985-989. 


\section{Supplementary material}

Fig. S1. Nucleotide and amino acid sequences of the expression cassettes of viral vectors TEV $\triangle$ NIb-CVB, TEVANIb-Cherry, TEV $\Delta$ NIb-Venus and TEV $\Delta$ NIb-Blue. The sequences of FLAG-mCherry, HA-Venus and c-Myc-mTagBFP are in red, green and blue, respectively, with the fragments corresponding to the tags (FLAG, HA and $\mathrm{c}-\mathrm{Myc}$ ) on gray background. The sequences of the different NlaPro proteolytic sites are in black with the cleavage sites marked on a yellow background. Silent mutations introduced in mCherry and mTagBFP cDNAs are underlined.

\section{Expression cassette TEVANIb-CVB}

GGGGAGAAGGACTACAAGGACGACGATGACAAAATGGTTAGCAAAGGCGAGGAGGATAACATGGCCATCATCAAGGA GTTCATGCGCTTCAAGGTGCACATGGAGGGCTCCGTGA ÄCGGCCĀCGAGTTCGAGATCGAGGGCGAGGGCGAGGGCC GCCCCTACGAGGGCACCCAGACCGCCAAGCTGAAGGTGACCAAGGGTGGCCCCCTGCCCTTCGCCTGGGACATCCTG TCCCСTCAGTTCATGTACGGCTCCAAGGCCTACGTGAAGCACCCCGCCGACATCCCCGACTACTTGAAGCTGTCCTT CCCCGAGGGCTTCAAGTGGGAGCGCGTGATGAACTTCGAGGACGGCGGCGTGGTGACCGTGACCCAGGACTCCTCCC TGCAGGACGGCGAGTTCATCTACAAGGTGAAGCTGCGCGGCACCAACTTCCССTCCGACGGCCCCGTAATGCAGAAG AAGACCATGGGCTGGGAGGCCTCCTCCGAGCGGATGTACCCCGAGGACGGCGCCCTGAAGGGCGAGATCAAGCAGAG GCTGAAGCTGAAGGACGGCGGCCACTACGACGCTGAGGTCAAGACCACCTACAAGGCCAAGAAGCCCGTGCAGCTGC CCGGCGCCTACAACGTCAACATCAAGTTGGACATCACCTCCCACAACGAGGACTACACCATCGTGGAACAGTACGAA CGCGCCGAGGGCCGCCACTCCACCGGCGGCATGGATGAGCTGTATAAGACGACTGAAAACTTGTACTTCCAAAGCGG САСTTACCCATACGATGTTCCAGATTACGCTATGGTGAGCAAGGG'CAGGAGCTGTTCACCGGGGTGGTGCCCATCC TGGTCGAGCTGGACGGCGACGTAAACGGCCACAAGTTCAGCGTGTCCGGCGAGGGCGAGGGCGATGCCACCTACGGC AAGCTGACCCTGAAGCTGATCTGCACCACCGGCAAGCTGCCCGTGCCСTGGCCCACCСTCGTGACCACCCTGGGCTA CGGCCTGCAGTGCTTCGCCCGCTACCCCGACCACATGAAGCAGCACGACTTCTTCAAGTCCGCCATGCCCGAAGGCT ACGTCCAGGAGCGCACCATCTTCTTCAAGGACGACGGCAACTACAAGACCCGCGCCGAGGTGAAGTTCGAGGGCGAC ACССTGGTGAACCGCATCGAGCTGAAGGGCATCGACTTCAAGGAGGACGGCAACATCCTGGGGCACAAGCTGGAGTA CAACTACAACAGCCACAACGTCTATATCACCGCCGACAAGCAGAAGAACGGCATCAAGGCCAACTTCAAGATCCGCC ACAACATCGAGGACGGCGGCGTGCAGCTCGCCGACCACTACCAGCAGAACACCCCCATCGGCGACGGCCCCGTGCTG CTGCCCGACAACCACTACCTGAGCTACCAGTCCGCCCTGAGCAAAGACCCCAACGAGAAGCGCGATCACATGGTCCT GCTGGAGTTCGTGACCGCCGCCGGGATCACTCTCGGCATGGACGAGCTGTACAAGACTACAGAGAACCTCTACTTTC AATCAGGTACAGAACAAAAACTTATTTCTGAAGAAGATCTGATGAGCGAGCTGATTAAGGAGAACATGCACATGAAG CTGTACATGGAGGGCACCGTGGACAACCATCACTTCAAGTGCACATCCGAGGGCGAAGGCAAGCCCTACGAGGGCAC CCAGACCATGAGAATCAAGGTGGTCGAGGGCGGCССTCTCСССTTCGССTTCGACATCСTGGCTACTAGCTTCСTCT ACGGCAGCAAGACCTTCATCAACCACACCCAGGGCATCCCCGACTTCTTCAAGCAGTCCTTCCCTGAAGGCTTCACA TGGGAGAGAGTCACCACATACGAAGACGGGGGCGTGCTGACCGCTACCCAGGACACCAGCCTCCAGGACGGCTGCCT CATCTACAACGTCAAGATCAGAGGGGTGAACTTCACATCCAACGGCCCTGTGATGCAGAAGAAAACACTCGGCTGGG AGGCCTTCACCGAGACGCTGTACCCCGCTGACGGCGGCCTGGAAGGCAGAAACGACATGGCCCTGAAGCTCGTGGGC GGGAGCCATCTGATCGCAAACATCAAGACCACATATAGATCCAAGAAACCCGCTAAGAACCTCAAGATGCCTGGCGT СTACTATGTGGACTACAGACTGGAAAGAATCAAGGAGGCCAACAACGAGACCTACGTCGAGCAGCACGAGGTGGCAG TGGCCAGATACTGCGACCTCCCTAGCAAACTGGGGCACAAGCTTAATACGACTGAGAATCTTTATTTTCAG

GEKDYKDDDDKMVSKGEEDNMAI IKEFMRFKVHMEGSVNGHEFEIEGEGEGRPYEGTQTAKLKVTKGGPLPFAWDIL SPQFMYGSKAYVKHPADIPDYLKLSFPEGFKWERVMNFEDGGVVTVTQDSSLQDGEF IYKVKLRGTNFP SDGPVMQK KTMGWEASSERMYPEDGALKGEIKQRLKLKDGGHYDAEVKTTYKAKKPVQLPGAYNVNIKLDITSHNEDYTIVEQYE RAEGRHSTGGMDELYKTTENLYFQSGTYPYDVPDYAMVSKGEELFTGVVP ILVELDGDVNGHKF SVSGEGEGDATYG KLTLKLICTTGKLPVPWPTLVTTLGYGLQCF ARYPDHMKQHDFFKSAMP EGYVQERTIFFKDDGNYKTRAEVKFEGD TLVNRIELKGIDFKEDGNILGHKLEYNYNSHNVYITADKQKNGIKANFKIRHNIEDGGVQLADHYQQNTP IGDGPVL LPDNHYLSYQSALSKDPNEKRDHMVLLEFVTAAGITLGMDELYKTTENLYFQSGTEQKLISEEDLMSELIKENMHMK LYMEGTVDNHHFKCTSEGEGKPYEGTQTMRIKVVEGGPLPFAFDILATSFLYGSKTF INHTQGIPDFFKQSFPEGFT WERVTTYEDGGVLTATQDTSLQDGCLIYNVKIRGVNFTSNGPVMQKKTLGWEAFTETLYPADGGLEGRNDMALKLVG GSHLIANIKTTYRSKKPAKNLKMPGVYYVDYRLERIKEANNETYVEQHEVAVARYCDLPSKLGHKLNTTENLYFQ

\section{Expression cassette TEVANIb-Cherry}

GGGGAGAAGGACTACAAGGACGACGATGACAAAATGGTTAGCAAAGGCGAGGAGGATAACATGGCCATCATCAAGGA GTTCATGCGCTTCAAGGTGCACATGGAGGGCTCCGTGĀ CGGCCĀCGAGTTCGAGATCGAGGGCGAGGGCGAGGGCC GCCССTACGAGGGCACCCAGACCGCCAAGCTGAAGGTGACCAAGGGTGGCCСССTGCCСTTCGCCTGGGACATCCTG TCCССTCAGTTCATGTACGGCTCCAAGGCCTACGTGAAGCACCCCGCCGACATCCCCGACTACTTGAAGCTGTCCTT 
CCCCGAGGGCTTCAAGTGGGAGCGCGTGATGAACTTCGAGGACGGCGGCGTGGTGACCGTGACCCAGGACTCCTCCC TGCAGGACGGCGAGTTCATCTACAAGGTGAAGCTGCGCGGCACCAACTTCCССTCCGACGGCCCCGTAATGCAGAAG AAGACCATGGGCTGGGAGGCCTCCTCCGAGCGGATGTACCCCGAGGACGGCGCCCTGAAGGGCGAGATCAAGCAGAG GCTGAAGCTGAAGGACGGCGGCCACTACGACGCTGAGGTCAAGACCACCTACAAGGCCAAGAAGCCCGTGCAGCTGC CCGGCGCCTACAACGTCAACATCAAGTTGGACATCACCTCCCACAACGAGGACTACACCATCGTGGAACAGTACGAA CGCGCCGAGGGCCGCCACTCCACCGGCGGCATGGATGAGCTGTATAAGACGACTGAGAATCTTTATTTTCAG

GEKDYKDDDDKMVSKGEEDNMAI IKEFMRFKVHMEGSVNGHEFEIEGEGEGRPYEGTQTAKLKVTKGGPLPFAWDIL SPQFMYGSKAYVKHP ADIPDYLKLSFPEGFKWERVMNFEDGGVVTVTQDSSLQDGEF IYKVKLRGTNFP SDGPVMQK KTMGWEASSERMYPEDGALKGEIKQRLKLKDGGHYDAEVKTTYKAKKPVQLPGAYNVNIKLDITSHNEDYTIVEQYE RAEGRHSTGGMDELYKTTENLYFQ

\section{Expression cassette TEV $\Delta \mathrm{NIb}-$ Venus}

GGGGAGAAGTACCCATACGATGTTCCAGATTACGCTATGGTGAGCAAGGGCGAGGAGCTGTTCACCGGGGTGGTGCC САTCCTGGTCGAGCTGGACGGCGACGTAAACGGCCACAAGTTCAGCGTGTCCGGCGAGGGCGAGGGCGATGCCACCT ACGGCAAGCTGACCCTGAAGCTGATCTGCACCACCGGCAAGCTGCCCGTGCCCTGGCCCACCCTCGTGACCACCCTG GGCTACGGCCTGCAGTGCTTCGCCCGCTACCCCGACCACATGAAGCAGCACGACTTCTTCAAGTCCGCCATGCCCGA AGGCTACGTCCAGGAGCGCACCATCTTCTTCAAGGACGACGGCAACTACAAGACCCGCGCCGAGGTGAAGTTCGAGG GCGACACCCTGGTGAACCGCATCGAGCTGAAGGGCATCGACTTCAAGGAGGACGGCAACATCCTG

GGGCACAAGCTGGAGTACAACTACAACAGCCACAACGTCTATATCACCGCCGACAAGCAGAAGAACGGCATCAAGGC CAACTTCAAGATCCGCCACAACATCGAGGACGGCGGCGTGCAGCTCGCCGACCACTACCAGCAGAACACCCCCATCG GCGACGGCCCCGTGCTGCTGCCCGACAACCACTACCTGAGCTACCAGTCCGCCCTGAGCAAAGACCCCAACGAGAAG CGCGATCACATGGTCCTGCTGGAGTTCGTGACCGCCGCCGGGATCACTCTCGGCATGGACGAGCTGTACAAGACGAC TGAGAATCTTTATTTTCAG

GEKYPYDVPDYAMVSKGEELFTGVVP ILVELDGDVNGHKFSVSGEGEGDATYGKLTLKLICTTGKLPVPWPTLVTTL GYGLQCFARYPDHMKQHDFFKSAMPEGYVQERT IFFKDDGNYKTRAEVKFEGDTLVNRIELKGIDFKEDGNILGHKL EYNYNSHNVYITADKQKNGIKANFKIRHNIEDGGVQLADHYQQNTP IGDGPVLLPDNHYLSYQSALSKDPNEKRDHM VLLEFVTAAGITLGMDELYKTTENLYFQ

\section{Expression cassette TEV $\Delta$ NIb-Blue}

GGGGAGAAGGAACAAAAACTTATTTCTGAAGAAGATCTGATGAGCGAGCTGATTAAGGAGAACATGCACATGAAGCT GTACATGGAGGGCACCGTGGACAACCATCACTTCAAGTGCACATCCGAGGGCGAAGGCAAGCCCTACGAGGGCACCC AGACCATGAGAATCAAGGTGGTCGAGGGCGGCCСTCTCCССTTCGCСTTCGACATCCTGGCTACTAGCTTCCTCTAC GGCAGCAAGACCTTCATCAACCACACCCAGGGCATCCCCGACTTCTTCAAGCAGTCCTTCCCTGAAGGCTTCACATG GGAGAGAGTCACCACATACGAAGACGGGGGCGTGCTGACCGCTACCCAGGACACCAGCCTCCAGGACGGCTGCCTCA TCTACAACGTCAAGATCAGAGGGGTGAACTTCACATCCAACGGCCCTGTGATGCAGAAGAAAACACTCGGCTGGGAG GCCTTCACCGAGACGCTGTACCCCGCTGACGGCGGCCTGGAAGGCAGAAACGACATGGCCCTGAAGCTCGTGGGCGG GAGCCATCTGATCGCAAACATCAAGACCACATATAGATCCAAGAAACCCGCTAAGAACCTCAAGATGCCTGGCGTCT ACTATGTGGACTACAGACTGGAAAGAATCAAGGAGGCCAACAACGAGACCTACGTCGAGCAGCACGAGGTGGCAGTG GCCAGATACTGCGACCTCCCTAGCAAACTGGGGCACAAGCTTAATACGACTGAGAATCTTTATTTTCAG

GEKEQKLISEEDLMSELIKENMHMKLYMEGTVDNHHFKCTSEGEGKPYEGTQTMRIKVVEGGPLPFAFDILATSFLY GSKTF INHTQGIPDFFKQSFPEGFTWERVTTYEDGGVLTATQDTSLQDGCLIYNVKIRGVNFTSNGPVMQKKTLGWE AFTETLYPADGGLEGRNDMALKLVGGSHLIANIKTTYRSKKPAKNLKMPGVYYVDYRLERIKEANNETYVEQHEVAV ARYCDLP SKLGHKLNTTENLYFQ 
Fig. S2. Fluorescence stereomicroscope images of different leaves of $N$. tabacum 35S::NIb inoculated with the defective viral vectors TEV $\Delta$ NIb-CVB, TEV $\Delta$ NIb-Cherry (a) or TEV-wt as a control (b). Filters were used to detect red, green and blue fluorescence. Leaves collected at 14 dpi are numbered acropetally following those infiltrated. Scale bar $2 \mathrm{~mm}$.

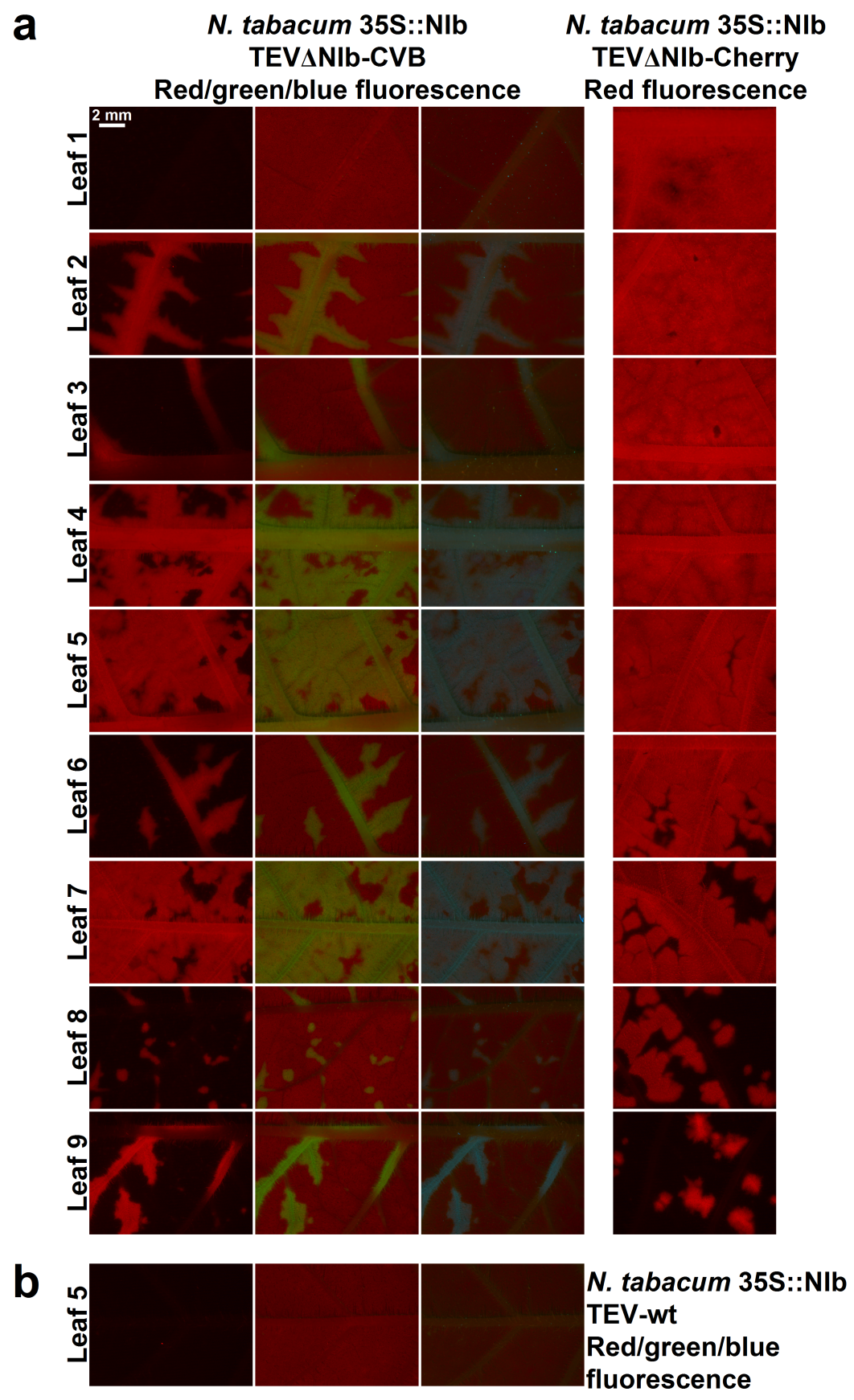


Fig. S3. Fluorescence stereomicroscope images of different leaves of $N$. tabacum 35S::NIb inoculated with sap of plants infected with TEV-wt (a), TEV $\Delta \mathrm{Nlb}$-Cherry, TEV $\Delta \mathrm{Nlb}$-Venus and TEV $\triangle$ Nlb-Blue (b) and TEV $\triangle N$ Ib-CVB (c). Three plants (1,2 and 3) were inoculated with sap collected at $11 \mathrm{dpi}$. Images were taken 10 days after the second inoculation. Filters were used to detect red, green and blue fluorescence. In the TEV-wt control (a) only images from one of the three replicate plants are shown. Scale bar $2 \mathrm{~mm}$.

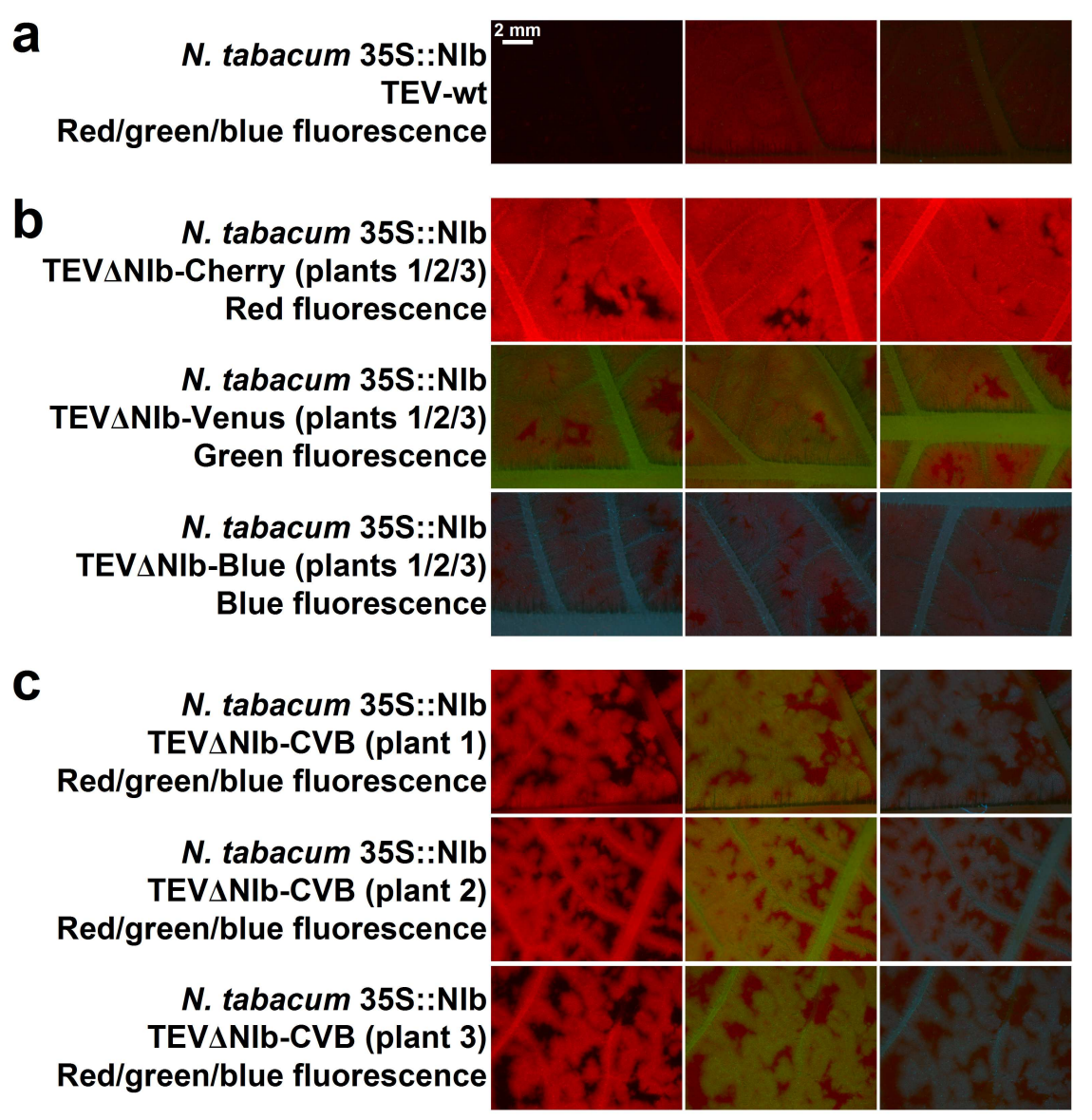

Fig. S4. Nucleotide and amino acid sequences of the expression cassettes of viral vector TEV $\Delta$ NIb-DelRos. The sequences of $A$. majus Delila (Genbank accession number M84913) and Rosea1 (Genbank accession number DQ275529) are in red and blue, respectively. The sequences of the different NlaPro proteolysis motifs are in black with the cleavage sites marked on yellow background. Mutations in Delila with respect to N84913 are underlined.

\section{Expression cassette TEV $\Delta$ NIb-DelRos}

GGGGAGAAGATGGCTACTGGTATCCAAAACCAAAAGATAGTGCCTGAGAATTTGAGGAAGCAACTTGCTATTGCTGT TAGAAGTATCCAATGGAGTTATGCAATTTCTGGTCCAATTCAGTTGCACAACCAGGGGTCTTGGAGTGGGGTGATG ĞGTCTACAATGGAGATATTAAAACTCGAAAAACTGTACAATCTGTCGAATTGAATCCCGATCAGCTGGGATTGCAG AGAAGTGATCAATTGAGAGAACTTTATGAGTCTCTTTCACTTGGTGAAACCAACACACAAGCTAAAAGGCCTACTGC TGCATTATCACCAGAAGACCTCACTGATGCTGAGTGGTTTTTCTTGGTTTGCATGTCTTTCATATTCAATATTGGCC AAGGGTTGCCTGGAAGAACATTAGCACGAAATCAAGCAGTATGGCTATGCAACGCTCATCGTGCGGACACCAAAGTT TTCTCGCGTTCTTTGCTTGCAAAGAGTGCGTCAATTCAGACAGTTGTGTGCTTTCCATATGCAGAAGGAGTAGTTGA GCTGGGAGCAACAGAGCTAGTACCGGAGGATTTGAATCTAATCCAGCATATAAAAACTTCATTCTTGGĀCAGTCCTG CCACCGTTCCCAAGATTCCCAACTATGTCTCCAACAGTATTACAAACAACAATGACCTCATTTGTGAAGCGCTTGAA CATGCTAATATACCAGAAAACGATCTTGATCAGCTTTTGAATTGTCCAGACACGAACATATGTTCTCCTGATAACAG TTTGGATGACTTTGCAGACAATTACTCATAGACGAATCGAATTTGGCAGAAGGCATCAATGGGGAGGTTCCTCAAA CACAAAGCTGGCCTTTCATGGATGATGCAATCAGCAATTGTCTCAATAGTTCTATGAATTCTAGTGACTGTATATCT CAAACTCATGAAAATCTAGAGTCTTTTGCTCCACTTTCTGATGGAAAAGGGCCACCGGAGACGAATAATTGTATGCA 


\section{RESULTADOS}

CAGCACTCAAAAATGCAATCAGCAGATAGAAAACACGGGTGTCCAAGGCGATGAGGTCCATTATCAAGGGGTACTTT CСAATCTTTTGAAGAGTTCCCATCAGTTGGTTCTTGGTCCСTACTTCAGAAATGGGAATAGAGAATCAAGCTTCGTT AGTTGGAACAAGGATGGATCGTCGGGTACTCATGTTCCCCGAAGCGGAACCTCACAAAGATTTCTGAAGAAAGTACT TTTTGAAGTAGCTAGAATGCATGAAAACTCCAGGCTTGATGCTGGTAAACAAAAAGGCAACAGTGACTGCCTTGCAA AGCCAACGGCTGATGAAATTGATAGAAACCACGTCTTGTCAGAGAGAAAACGCA $\overline{G A G A G A A A A T A A A C G A A C G G T T T ~}$ ATGATTCTTGCATCCCTAGTCCCATCCGGTGGCAAGGTTGACAAAGTATCAATACTAGACCATACAATAGATTACTT GAGAGGGCTTGAGAGGAAAGTCGACGAGCTGGAATCTAACAAAATGGTAAAGGGCCGGGGGCGGGAATCAACTACAA AAACTAAACTGCACGATGCCATTGAGAGGACCTCCGATAATTATGGCACAACAAGGACAAGTAATGTCAAGAAACCG TTGACAAACĀ̄GAGAAAGGCTTCTGATACGGACĀ̄GATTGGAGCCGTĀAATAGCAGAGGTCGATTGAAAGATTCCTT AACAGATAATATAACTGTGAACATTACAAACAAGGATGTGTTGATTGTCGTGAGTTGTTCTTCCAAGGAGTTTGTAT TGCTTGAAGTGATGGAAGCCGTAAGACGACTAAGTTTGGATTCCGAAACTGTTCAATCTTCCAACAGAGATGGAATT ATATCCATTACCATAAAAGCCAAGTGCAAGGGATTGAAGGTTGCATCAGCAAGTGTGATCAAACAAGCTCTTCAGAA AGTTACTATGAAGTCTACTACAGAGAACCTCTACTTTCAATCAGGTACAATGGAAAAGAATTGTCGTGGAGTGAGAA AAGGTACTTGGACCAAAGAAGAAGACACTCTCTTGAGGCAATGTATAGAAGAGTATGGTGAAGGGAAATGGCATCAA GTTCCACACAGAGCAGGGTTGAACCGGTGTAGGAAGAGTTGCAGGCTGAGGTGGTTGAATTATCTGAGGCCAAATAT CAAAAGAGGTCGGTTTTCGAGAGATGAAGTGGACCTAATTGTGAGGCTTCATAAGCTGTTGGGTAACAAATGGTCGC TGATTGCTGGTAGAATTCCTGGAAGGACAGCTAATGACGTGAAGAACTTTTGGAATACTCATGTGGGGAAGAATTTA GGCGAGGATGGAGAACGATGCCGGAAAAATGTTATGAACACAAAAACCATTAAGCTGACTAATATCGTAAGACCCCG AGCTCGGACCTTCACCGGATTGCACGTTACTTGGCCGAGAGAAGTCGGAAAAACCGATGAATTTTCAAATGTCCGGT TAACAACTGATGAGATTCCAGATTGTGAGAAGCAAACGCAATTTTACAATGATGTTGCGTCGCCACAAGATGAAGTT GAAGACTGCATTCAGTGGTGGAGTAAGTTGCTAGAAACAACGGAGGATGGGGAATTAGGAAACCTATTCGAGGAGGC CCAACAAATTGGAAATACGACTGAGAATCTTTATTTTCAG

GEKMATGIQNQKIVPENLRKQLAIAVRSIQWSYAIFWSNSVAQPGVLEWGDGFYNGDIKTRKTVQSVELNPDQLGLQ RSDQLRELYESLSLGETNTQAKRPTAALSPEDLTDAEWFF LVCMSF IFNIGQGLP GRTLARNQAVWLCNA HRADTKV FSRSLLAKSASIQTVVCFPYAEGVVELGATELVPEDLNLIQHIKTSFLDSPATVPKIPNYVSNSITNNNDLICEALE HANIPENDLDQLLNCPDTNICSPDNSLDDFADNLLIDESNLAEGINGEVPQTQSWPFMDDAISNCLNSSMNSSDCIS QTHENLESFAPLSDGKGPPETNNCMHSTQKCNQQIENTGVQGDEVHYQGVLSNLLKSSHQLVLGPYFRNGNRESSFV SWNKDGSSGTHVPRSGTSQRFLKKVLFEVARMHENSRLDAGKQKGNSDCLAKPTADEIDRNHVLSERKRREKINERF MILASLVPSGGKVDKVSILDHTIDYLRGLERKVDELESNKMVKGRGRESTTKTKLHDAIERTSDNYGTTRTSNVKKP LTNKRKASDTDKIGAVNSRGRLKDSLTDNITVNITNKDVLIVVSCSSKEFVLLEVMEAVRRLSLDSETVQSSNRDGI ISITIKAKCKGLKVASASVIKQALQKVTMKSTTENLYFQSGTMEKNCRGVRKGTWTKEEDTLLRQCIEEYGEGKWHQ VPHRAGLNRCRKSCRLRWLNYLRPNIKRGRF SRDEVDLIVRLHKLLGNKWSLIAGRIPGRTANDVKNFWNTHVGKNL GEDGERCRKNVMNTKTIKLTNIVRPRARTFTGLHVTWPREVGKTDEF SNVRITTDEIPDCEKQTQFYNDVASPQDEV EDCIQWWSKLLETTEDGELGNLFEEAQQIGNTTENLYFQ 
Table S1

Primers utilized for plasmid construction and RT-PCR amplification indicating the sequence, features and use.

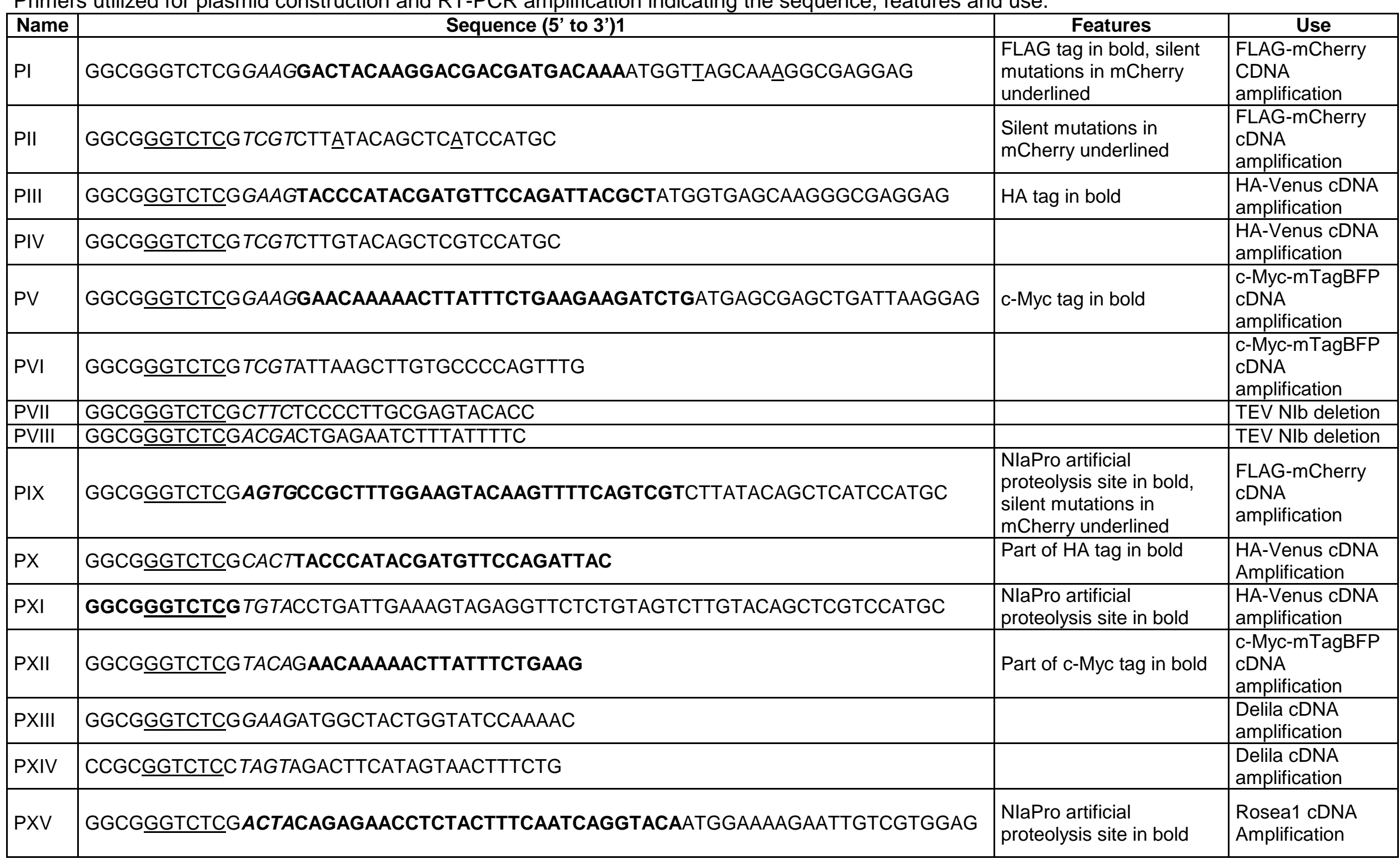




\begin{tabular}{|c|c|c|c|}
\hline PXVI & CCGCGGTCTCCTCGTATTTCCAATTTGTTGGGCCTC & & $\begin{array}{l}\text { Rosea1 cDNA } \\
\text { amplification }\end{array}$ \\
\hline PXVII & GGCGATCGATGGGGGAGAAGAGGAAATGGGTC & $\begin{array}{l}\text { Amino terminal ATG in } \\
\text { bold, phosphorylated at } \\
\text { the 5' end }\end{array}$ & $\begin{array}{l}\text { TEV Nlb cDNA } \\
\text { amplification }\end{array}$ \\
\hline PXVIII & GGCGGGTCTCGTCGATCACTGAAAATAAAGATTCTCAGTC & Stop codon in bold & $\begin{array}{l}\text { TEV NIb cDNA } \\
\text { amplification }\end{array}$ \\
\hline PXIX & CTCGCACTACATAGGAGAATTAGAC & $\begin{array}{l}\text { Complementary TEV- } \\
\text { DQ986288 } \\
\text { positions 9,471-9,495 }\end{array}$ & $\begin{array}{l}\text { TEV RNA reverse } \\
\text { transcription }\end{array}$ \\
\hline PXX & AGTGGCACTGTGGGTGCTGGTGTTG & $\begin{array}{l}\text { Homologous to TEV- } \\
\text { DQ986288 } \\
\text { positions } 8,518-8,542\end{array}$ & $\begin{array}{l}\text { PCR TEV } \\
\text { diagnosis }\end{array}$ \\
\hline PXXI & CTGGCGGACCCCTAATAG & $\begin{array}{l}\text { Complementary to TEV- } \\
\text { DQ986288 } \\
\text { positions } 9,289-9,306\end{array}$ & $\begin{array}{l}\text { PCR TEV } \\
\text { diagnosis }\end{array}$ \\
\hline PXXII & CATGAGTGAATTGGTGTACTCGCAA & $\begin{array}{l}\text { Homologous to TEV- } \\
\text { DQ986288 } \\
\text { positions } 6,957-6,981\end{array}$ & $\begin{array}{l}\text { Expression } \\
\text { cassette } \\
\text { PCR amplification }\end{array}$ \\
\hline PXXIII & CAACACCAGCACCCACAGTGCCACT & $\begin{array}{l}\text { Complementary to TEV- } \\
\text { DQ986288 } \\
\text { positions } 8,518-8,542\end{array}$ & $\begin{array}{l}\text { Expression } \\
\text { cassette } \\
\text { PCR amplification }\end{array}$ \\
\hline
\end{tabular}

1 In all cloning primers from PI to PXVI plus PXVIII, Eco31I recognition sites (GGTCTC) underlined and Eco31I cleavage sites in italics. 
CAPÍTULO 5. RESULTADOS:

SUPLEMENTACIÓN DEL VECTOR DE EXPRESIÓN BASADO EN EL TEV CON UN SUPRESOR VIRAL ADICIONAL DEL SILENCIAMIENTO GÉNICO 


\section{INTRODUCCIÓN}

Además del papel que cumple el silenciamiento génico inducido por RNA en la regulación de la expresión de genes en las plantas, también juega un papel fundamental en la defensa contra patógenos, como los virus, para contrarrestar el proceso de infección (Waterhouse et al., 2001). Los virus a su vez han desarrollado mecanismos para enfrentar esta maquinaria de defensa, como las proteínas supresoras que interfieren en las rutas basadas en el procesamiento de RNAs de doble cadena (dsRNAs) y obtención de pequeños RNAs (sRNAs) que desencadenan el proceso de silenciamiento génico (Csorba et al., 2009). Dichos supresores suelen ser proteínas virales multifuncionales, inicialmente descritas como factores de patogenicidad vitales para que se desarrolle la infección, y que pueden interferir de diferentes formas dentro de la ruta del silenciamiento mediado por sRNAs en plantas. Por ejemplo, la proteína HC-Pro (o la combinación P1/HC-Pro), codificada en el genoma del virus del grabado del tabaco (Tobacco etch virus, TEV), y relacionada con numerosas funciones como la transmisión por áfidos del virus o el desarrollo de síntomas, fue el primer supresor del silenciamiento descrito (Anandalakshmi et al., 1998; Kasschau y Carrington, 1998). Esta proteína multifuncional puede interferir en más de un punto dentro del proceso del silenciamiento y producir una gran variedad de efectos dependiendo del virus, a pesar de lo cual su capacidad de unir sRNA se acepta generalmente como una de sus características más relevantes y que sugiere su acción para impedir la amplificación de la señal de silenciamiento en la planta (Mallory et al., 2002). Otra, la proteína 2b, una de las cinco proteínas codificadas por el virus del mosaico del pepino (Cucumber mosaic virus, CMV), desempeña distintas funciones y está relacionada con el desarrollo de síntomas, el movimiento del virus y la supresión de mecanismos de defensa vegetales como la resistencia mediada por ácido salicílico y el silenciamiento basado en RNA (Lewsey et al., 2010). Su actividad supresora es amplia y en parte se atribuye a la capacidad de unir dsRNAs e interactuar con proteínas del complejo RISC como AGO1 y 4. De este modo interfiere tanto en la acumulación de microRNAs de las plantas huéspedes, afectando su regulación de la expresión genética, como de siRNAs derivados del virus (González et al., 2010). El virus del cascabeleo del tabaco (Tobacco rattle virus, TRV), cuyo genoma se compone de 2 moléculas de RNA de sentido positivo, codifica en su RNA1 la proteína rica en cisteínas 16K. Aunque es esencial para que ocurra la replicación del virus, su función se desconocía hasta que estudios como el de Reavy et al. (2004), expresando 16K en 
células de Drosophila, demostraron que esta proteína funciona como supresor del silenciamiento. En algunos estudios posteriores se comprobó su actividad suprimiendo el silenciamiento de la GFP en plantas de Nicotiana benthamiana, y se ha sugerido que actúa en los primeros pasos del proceso de silenciamiento, impidiendo su inicio o mantenimiento, ya que es incapaz de ejercer su actividad supresora una vez el proceso se ha establecido y diseminado a otras partes de la planta (Ghazala et al., 2008; Martínez-Priego et al., 2008). Por otro lado, se encuentra la proteína P19 del virus del enanismo arbustivo del tomate (Tomato bushy stunt virus, TBSV), con actividades variadas y específicas en determinadas plantas huésped (Scholthof, 2006), y descrita por Voinnet et al. (1999) como supresor del silenciamiento después de estudiar su capacidad para restaurar la expresión de la GFP en determinadas zonas de plantas transformadas con este gen reportero y en las cuales se había silenciado su expresión. Estudios posteriores han indicado que esta proteína supresora forma dímeros y actúa principalmente uniendo siRNAs de doble cadena, en especial de 21 nucleótidos (nt), para impedir su interacción con componentes del complejo RISC y así detener el proceso de silenciamiento (Omarov et al., 2006).

Las proteínas supresoras del silenciamiento, gracias a su variedad y diversidad en el modo de acción, también pueden considerarse herramientas potenciales para mejorar los sistemas de expresión de proteínas en plantas. Por ejemplo, se ha estudiado la capacidad de distintos supresores de mejorar la expresión de la proteína GFP cuando se realizan ensayos de expresión transitoria, encontrando que muchos de ellos pueden aumentar considerablemente dicha expresión y mantenerla durante un tiempo más largo (Chiera et al., 2008), sugiriendo su posible aplicación en la inserción de transgenes heterólogos en plantas. Asímismo, se ha visto que algunos supresores pueden mejorar el proceso de infección de virus vegetales (Siddiqui et al., 2008), hecho que indicaría la posibilidad de aumentar los niveles de expresión de proteínas recombinantes con vectores virales.

En este estudio se investigó el efecto de introducir cuatro supresores distintos del silenciamiento en el vector de expresión simple pGTEV $\Delta$ NIb-mCherry, situándolos entre la proteína reportera y el gen de la proteína de cubierta (CP). Se agroinocularon con las distintas construcciones plantas de tabaco (Nicotiana tabacum) transgénicas, que expresan la proteína viral NIb, y se compararon los niveles de expresión de la 
proteína reportera en tejido tomado 12 días después de la inoculación. Los resultados mostraron que la proteína P19 del TBSV y, en menor medida, la 2b del CMV, pueden mejorar la expresión de mCherry, demostrando el potencial de emplear supresores del silenciamiento para aumentar los niveles de expresión de proteínas por medio del vector de expresión basado en el TEV.

\section{MATERIALES Y MÉTODOS}

\section{$\underline{\text { Construcción de plásmidos }}$}

El plásmido pGTEV contiene un cDNA infeccioso del TEV (Genbank no DQ986288), flanqueado por el promotor y terminador 35S del CaMV (Bedoya y Darós, 2010). El plásmido pTEV3 $\triangle$ NIb-mCherry contiene un fragmento de cDNA del TEV-DQ986288 en el que el cistrón de la Nlb se ha sustituido por el cDNA de la proteína fluorescente mCherry. Los supresores se amplificaron por PCR a partir de los correspondientes clones virales y con los cebadores descritos en la Tabla 5.1. El supresor 2b se amplificó del aislado FNY del virus del mosaico del pepino (Rizzo and Palukaitis, 1990). Todas las reacciones de PCR se realizaron en $20 \mu$ con $0.4 \mathrm{U}$ de DNA polimerasa Phusion (Finnzymes) de alta fidelidad de copia en tampón HF (Finnzymes), 3\% DMSO, 0.2 mM dNTPs, $0.5 \mu \mathrm{M}$ de cada cebador y $10 \mathrm{ng}$ de DNA molde. Las reacciones se incubaron por $30 \mathrm{~s}$ a $98^{\circ} \mathrm{C}$, seguido de 30 ciclos de $10 \mathrm{~s}$ a $98^{\circ} \mathrm{C}, 30 \mathrm{~s}$ a $55^{\circ} \mathrm{C}$ y $30 \mathrm{~s}$ a $72{ }^{\circ} \mathrm{C}$, y con una extensión final de 10 min a $72 \stackrel{\circ}{\circ}$. Los productos de PCR y los plásmidos se trataron según las técnicas estándar basadas en el uso de la enzima de restricción tipo Ils Eco31l (Fermentas), se ligaron con la T4 DNA ligasa (Fermentas) y se transformaron en Escherichia coli DH5a por electroporación (ECM 399, BTX). Los cDNAs de los supresores se insertaron inicialmente en el vector pTEV3 $\triangle$ NIb-mCherry tras el gen reportero, y posteriormente se transfirieron a pGTEV, por digestión y ligación con las enzimas Eco81l-Apal (Fermentas), obteniéndose los plásmidos pTEV $\Delta$ NIb-mCherry.HC-Pro, pTEVANIb-mCherry.2b, pTEVANIb-mCherry.16K y pTEVANIb-mCherry.P19.

\section{$\underline{\text { Inoculación de plantas }}$}

Se inocularon plantas de tabaco transgénicas (Nicotiana tabacum L. cv. Xanthi nc) que expresan la proteína NIb del TEV (Li y Carrington, 1995), de alrededor de 5 semanas 
de edad, realizando dos infiltraciones en la tercera hoja verdadera y manteniéndolas en una cámara de cultivo con un fotoperíodo de 12 h día a $25^{\circ} \mathrm{C}$ y 12 h noche a $23^{\circ} \mathrm{C}$. La agroinoculación se realizó con cultivos de Agrobacterium tumefaciens C58C1 conteniendo el plásmido auxiliar pCLEAN-S48 (Thole et al., 2007) y los plásmidos pGTEV (wt), pTEV $\Delta$ NIb-mCherry, pTEV $\Delta$ NIb-mCherry.HC-Pro, pTEV $\Delta$ NIb-mCherry.2b, pTEV $\Delta$ NIb-mCherry.16K y pTEV $\Delta$ NIb-mCherry.P19, ajustados a una densidad óptica (DO) $(600 \mathrm{~nm})$ de aproximadamente 0.5 e inducidos a $28 \stackrel{\circ}{\circ}$ por $2 \mathrm{~h}$ con $150 \mu \mathrm{M}$ acetosiringona como se ha descrito anteriormente (Bedoya y Darós, 2010; ver capítulo 3).

Tabla 5.1. Cebadores usados para la amplificación de los cDNAs de los distintos supresores del silenciamiento virales. Sitios Eco31I subrayados.

\begin{tabular}{|c|l|l|l|}
\hline SUPRESOR & \multicolumn{1}{|c|}{ VIRUS } & CEBADOR DIRECTO & CEBADOR REVERSO \\
\hline HC-Pro & Plum pox virus & $\begin{array}{l}\text { GGCGGGTCTCGCACTTCAGA } \\
\text { CCCAGGCAAACAATTTTC }\end{array}$ & $\begin{array}{l}\text { GGCGGGTCTCGTCGTTCCAA } \\
\text { CCAGGTATGTTTTC }\end{array}$ \\
\hline $2 \mathrm{~b}$ & Cucumber mosaic virus & $\begin{array}{l}\text { GGCGGGTCTCGCACTATGGA } \\
\text { ATTGAACGTAGGTGC }\end{array}$ & $\begin{array}{l}\text { GGCGGGTCTCGTCGTGAAA } \\
\text { CACCTTCCGCCCATT }\end{array}$ \\
\hline $16 \mathrm{~K}$ & Tobacco rattle virus & $\begin{array}{l}\text { GGCGGGTCTCGCACTATGAC } \\
\text { GTGTGTACTCAAGGG }\end{array}$ & $\begin{array}{l}\text { GGCGGGTCTCGTCGTAAAAG } \\
\text { CAAACAAACGATCAATC }\end{array}$ \\
\hline P19 & $\begin{array}{l}\text { Tomato bushy stunt } \\
\text { virus }\end{array}$ & $\begin{array}{l}\text { GGCGGGTCTCGCACTATGGA } \\
\text { ACGAGCTATACAAGG }\end{array}$ & $\begin{array}{l}\text { GGCGGGTCTCGTCGTCTCGC } \\
\text { TTTCTTTTTCGAAGG }\end{array}$ \\
\hline
\end{tabular}

\section{Análisis de fluorescencia}

Transcurridos 12 días de la inoculación con los distintos cultivos, se recogió tejido sintomático para analizar la fluorescencia de mCherry. En primer lugar se hizo un estudio visual por medio de una lupa de fluorescencia Leica MZ 16 F equipada con el filtro DSR (Leica). Los tiempos de exposición fueron de $10.1 \mathrm{~ms}$ para luz blanca y $5.1 \mathrm{~s}$ para fluorescencia. Posteriormente, se recogieron aproximadamente $400 \mathrm{mg}$ de tejido representativo dentro de las zonas con fluorescencia, tomando para cada construcción tres réplicas correspondientes a tres plantas distintas. Dicho tejido se preparó homogenizando con un procesador manual (Tissueruptor, Qiagen) en 10 volúmenes de tampón de extracción (0.1 M carbonato de sodio, $\mathrm{pH} 9.6)$, manteniendo en todo momento en hielo. Se tomó una alícuota del homogenizado para centrifugar 5 minutos y recuperar el sobrenadante. Se sirvieron $200 \mu \mathrm{l}$ de cada muestra en una placa de 96 pocillos de paredes opacas (Greiner Bio-one) y se hizo la medición de la fluorescencia de mCherry con el fluorímetro VICTOR ${ }^{\mathrm{TM}}$ X5 Multilabel Plate Reader (Perkin Elmer), siguiendo un protocolo de excitación a 570 nm y emisión a 610 nm. 


\section{RESULTADOS Y DISCUSIÓN}

Con el objetivo de mejorar el nivel de expresión de proteínas heterólogas por medio del vector basado en el TEV desarrollado con anterioridad (Bedoya et al., 2010), se ensayó el efecto de cuatro diferentes supresores del silenciamiento virales en el vector que expresa la proteína mCherry en sustitución de la RNA polimerasa viral Nlb. Los cDNAs correspondientes a los supresores de los virus de la sharka de los frutales de hueso (Plum pox virus, PPV) (HC-Pro), CMV (2b), TRV (16K) y TBSV (P19) se insertaron seguidamente de mCherry y separados de la misma por un sitio de procesamiento artificial de la proteasa viral NlaPro (Fig. 5.1).

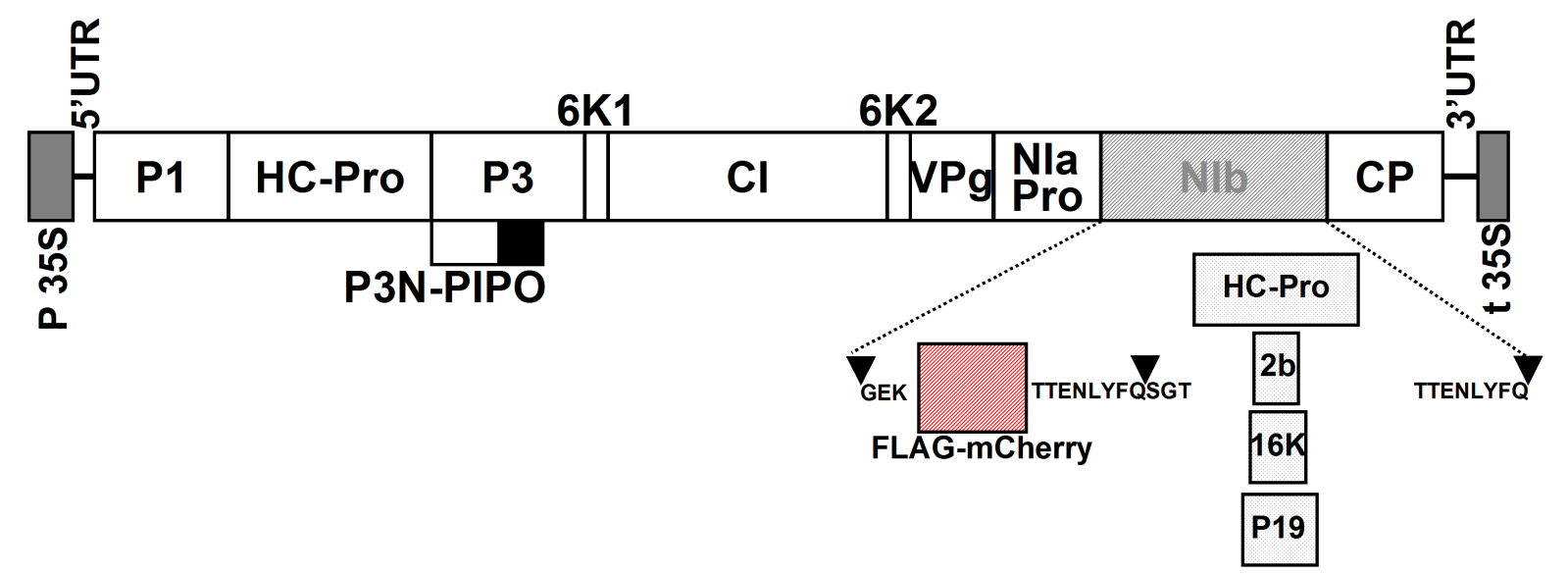

Figura 5.1. Diagrama del vector con los distintos supresores del silenciamiento. El cistrón de la NIb se ha reemplazado por un casete con los cDNAs de la proteína reportera mCherry y cada una de las proteínas supresoras analizadas, separadas entre sí por un sitio de procesamiento de la proteasa NlaPro.

Se agroinocularon con los diferentes plásmidos construidos plantas de tabaco transgénicas, que se sabe suplementan en trans la actividad Nlb (Li y Carrington, 1995), para analizar la influencia que los diferentes supresores del silenciamiento insertados pueden tener en la expresión de mCherry. En lo referente a los síntomas, aunque hubo algunas diferencias en el tiempo de aparición para las plantas inoculadas con las distintas construcciones con respecto al control TEVANlb-mCherry, estas pueden deberse simplemente al hecho de que el vector tenga una proteína adicional y, en todo caso, aproximadamente una semana después de la inoculación todas las plantas presentaban los síntomas típicos generados por el TEV distribuidos en las hojas más apicales. Al observar dicho tejido con la lupa de fluorescencia, asímismo, se vio la correcta expresión de la proteína mCherry en todos los casos y a simple vista los niveles de fluorescencia en todos los casos fueron muy similares. La única diferencia 
se observó en hojas inoculadas con el vector TEV $\Delta$ NIb-mCherry.HC-Pro, en las que la proteína reportera parecía tener una distribución levemente distinta a las demás muestras, con zonas sin fluorescencia (Fig. 5.2), posiblemente como consecuencia de una menor acumulación del virus.

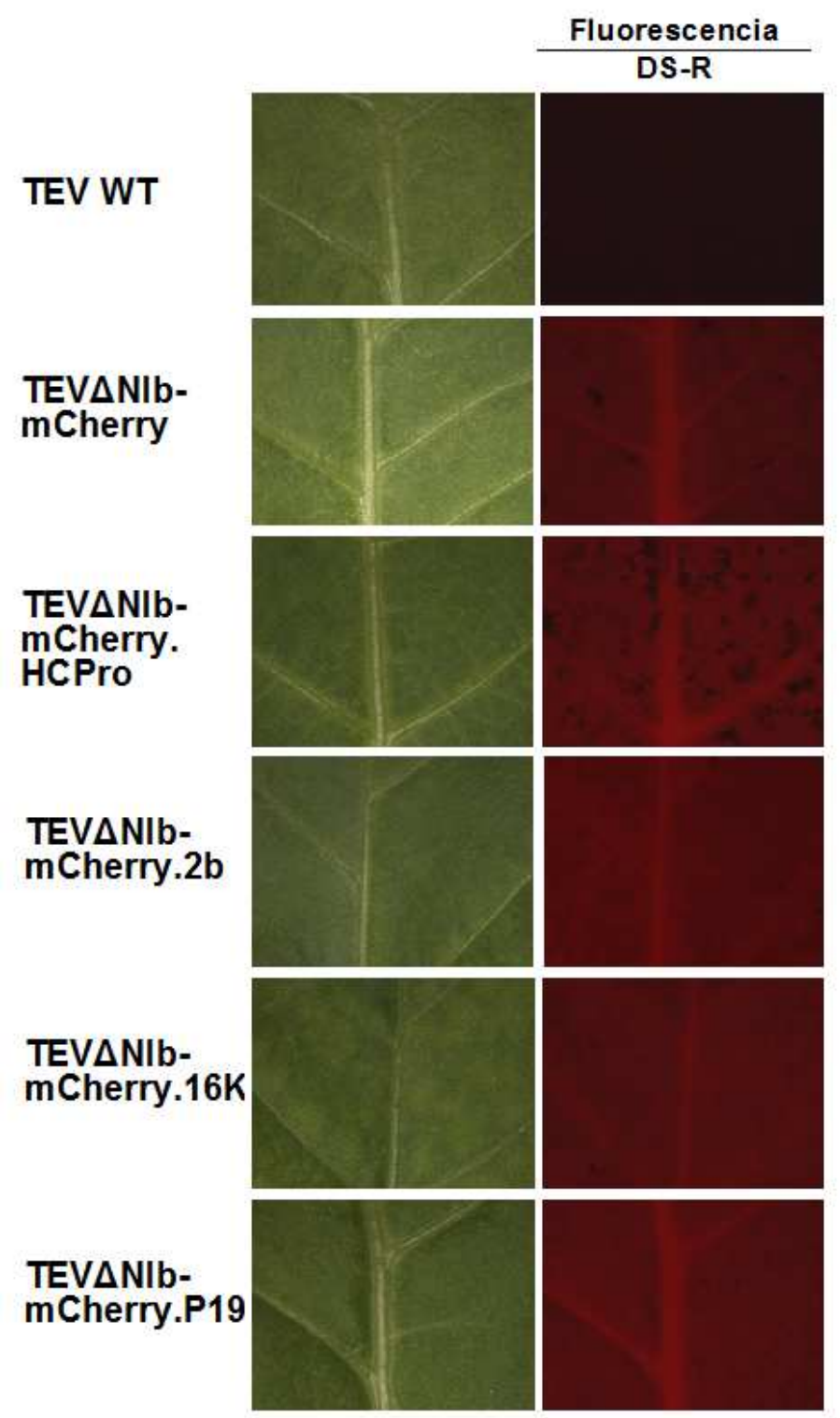

Figura 5.2. Expresión de la proteína reportera mCherry. Se muestran imágenes representativas de fluorescencia en hojas de tabaco transgénico inoculado con las diferentes construcciones.

Posteriormente, a partir de extractos del tejido recolectado, se hizo una valoración cuantitativa con fluorímetro de la expresión de la proteína mCherry, relacionando valores más altos de fluorescencia con una mayor concentración de la proteína en el extracto. En el análisis se incluyó la medida de extractos de plantas inoculadas con el virus WT, para descartar la porción de la fluorescencia atribuible a otros factores, no relacionados con la presencia de mCherry. Al realizar la corrección de todos los valores obtenidos restando el valor medio de dichas medidas, y representar los resultados para 
estudiar el aumento o disminución de la fluorescencia que se genera con los cuatro supresores, se observó que las proteína P19 y 2b fueron las únicas en producir un aumento en la expresión de mCherry, mientras que las proteínas $16 \mathrm{~K}$ y HC-Pro presentaron valores muy similares o menores que el control (Fig. 5.3).

El resultado más interesante fue el obtenido con el supresor del silenciamiento P19 del TBSV, con el que hubo un aumento en la expresión de la proteína fluorescente reportera, observándose una diferencia significativa de aproximadamente un $50 \%$ con respecto al valor medio del control sin ningún supresor adicional (Fig. 5.3). Este hecho reafirma la idea de que éste es un supresor muy potente, para el que se ha descrito en otros casos su utilidad en la mejora de expresión de proteínas en ensayos de expresión transitoria con Agrobacterium tumefaciens (Voinnet et al., 2003). El supresor P19 ha sido ampliamente estudiado y se sabe que interfiere en el proceso de silenciamiento uniendo pequeños RNAs (sRNAs) de doble cadena, y evitando su interacción con componentes del complejo RISC para su ensamblaje y activación (Lakatos et al., 2004). En este caso, además, se vio que P19 es capaz de ejercer su fuerte función supresora en unión con el supresor HC-Pro que contiene el vector viral y, aunque no se puede saber de que manera interactúan, es posible que la acción individual de cada uno no solamente no interfiera con la del otro sino que en conjunto sean capaces de contener de mejor forma el proceso de silenciamiento de las plantas, ya que ambos tienen una estrategia similar de supresión uniendo sRNAs y evitando el funcionamiento del complejo RISC (Lakatos et al., 2006).

Algo similar ocurrió con la proteína $2 \mathrm{~b}$ del CMV, la cual provocó un aumento significativo en la expresión de mCherry de alrededor del $20 \%$ con respecto al control (Fig. 5.3). Ensayos realizados con 2b, proteína de localización nuclear, sugieren que interviene en el proceso de silenciamiento interfiriendo en el movimiento de la señal silenciadora a otras partes de la planta, ya que es capaz de prevenirlo en tejidos donde todavía no se ha establecido, hecho que además se ha relacionado con el proceso de metilación del gen a silenciar (Guo y Ding, 2002; Goto et al., 2007). Igualmente, aunque el aumento en la expresión de mCherry no fue tan alto como con P19, 2b también es capaz de actuar en conjunción con la HC-Pro del TEV, posiblemente complementando su acción al ejercitar su función de forma diferente y en otros puntos de la ruta de silenciamiento. Este hecho podría estar relacionado de alguna manera con la 
capacidad sinergística que ha mostrado el CMV con respecto a diferentes virus de vegetales (Wang et al., 2004).

Por otro lado, las proteínas 16K del TRV y HC-Pro del PPV no produjeron ningún aumento en la expresión de la proteína fluorescente reportera mCherry, y en el segundo caso hubo una disminución de casi un 10\% en la fluorescencia (Fig. 5.3). Ghazala et al. (2008) encontraron que el supresor $16 \mathrm{~K}$ es capaz de disminuir los niveles de sRNAs derivados de la proteína GFP, indicando que esta proteína puede actuar en los primeros pasos del silenciamiento previniendo el procesamiento de RNAs de doble cadena. Sin embargo, en combinación con HC-Pro la proteína 16K no tuvo ningún efecto significativo, e incluso generó una leve disminución en los niveles de expresión de mCherry. Como se ha indicado (Martínez-Priego et al., 2008), 16K puede actuar como un supresor mucho más débil que HC-Pro y su actividad puede verse disminuida cuando se presentan altos niveles de RNAs de doble cadena, que en este caso pueden alcanzarse por la alta capacidad de infección del vector viral.

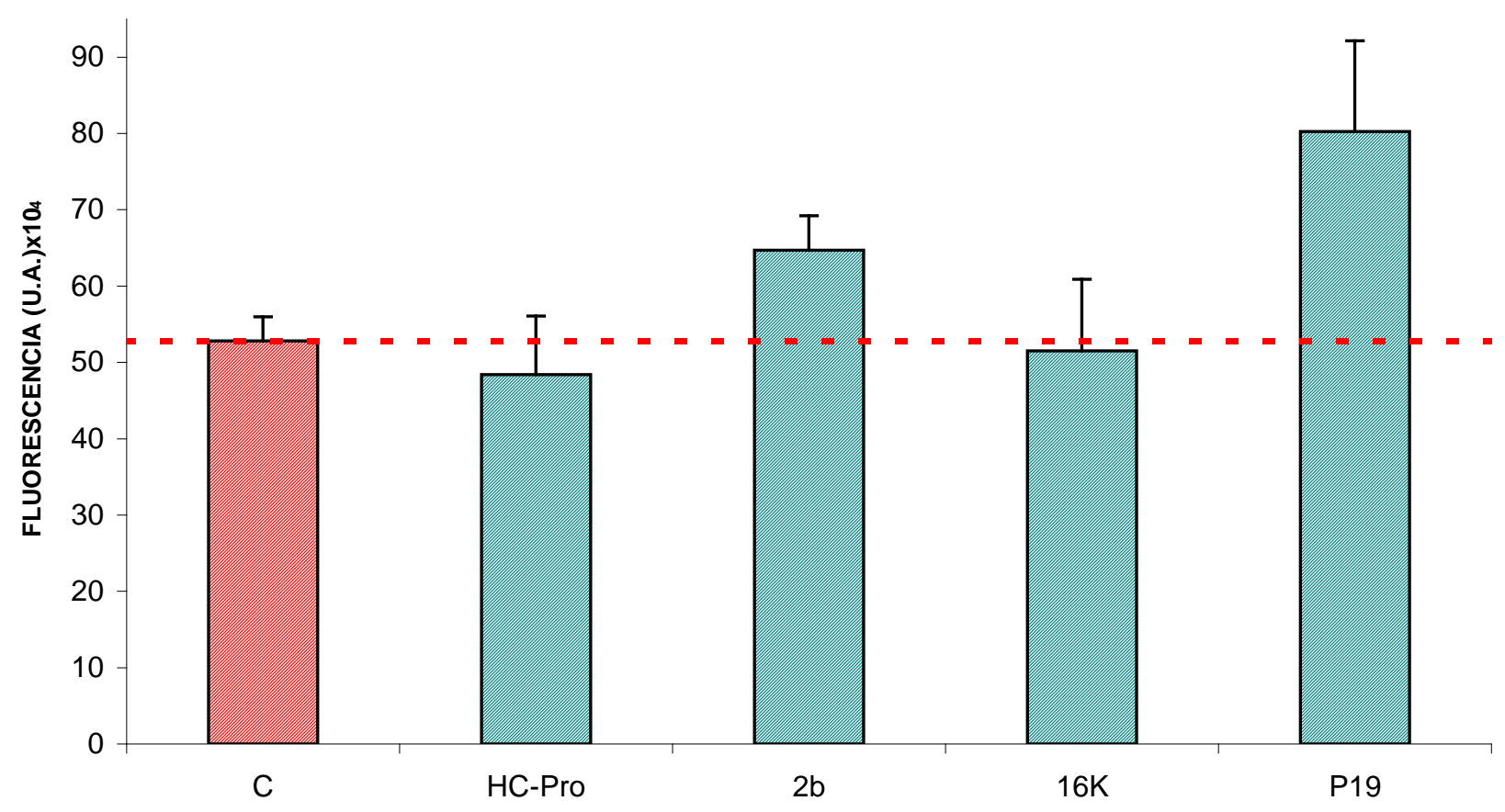

Figura 5.3. Representación gráfica de la fluorescencia medida en extractos de plantas inoculadas con las diferentes construcciones llevando los supresores HC-Pro (PPV), 2b (CMV), 16K (TRV) y P19 (TBSV). Se representa la media y error estándar de tres réplicas biológicas. La muestra $C$ corresponde al control TEV $\Delta N$ Ib-mCherry sin supresor adicional y la línea roja indica su valor medio. La fluorescencia se mide en unidades arbitrarias (U.A.). 
En el caso de la proteína HC-Pro, además de ser multifuncional, es un fuerte supresor que puede actuar en diferentes etapas dentro de la ruta del silenciamiento en plantas. Por ejemplo, se sabe que bloquea el mantenimiento del silenciamiento, ya que une pequeños RNAs de doble cadena (Shiboleth et al., 2007), o que interfiere en la actividad RNA endonucleasa de proteosomas en las células vegetales (Ballut et al., 2005). Su mismo descubrimiento como supresor se debe a su alta capacidad de sinergismo con otros virus, mejorando su capacidad de infección y acumulación (Pruss et al., 1997). Sin embargo, en el presente estudio al combinar dos proteínas similares pero de distintos virus como lo son el TEV y el PPV, se produjo una reducción en la expresión de mCherry. Aunque no se estudió a nivel molecular lo que esta ocurriendo, este hecho podría sugerir que una segunda copia heteróloga de HC-Pro no solo no actúa aditivamente en la función supresora, sino que además puede interferir hasta cierto nivel en el correcto funcionamiento de la primera por no poseer las mismas características que la proteína propia del TEV, y tal vez incluso interactúa de forma menos eficiente con los otros factores virales.

En conjunto, los resultados de este estudio muestran que es posible aumentar la eficiencia en la expresión de proteínas por medio del vector viral basado en el TEV desarrollado anteriormente, insertando las proteínas 2b del CMV o P19 del TBSV, las cuales junto con la HC-Pro que posee el vector son tres de los supresores más estudiados y potentes (Roth et al., 2004). Además, en comparación con otros tipos de estudios realizados en los que se han evaluado individualmente diferentes supresores del silenciamiento (Chiera et al., 2008; Dhillon et al., 2009), los resultados aquí descritos muestran la posibilidad de combinar más de una proteína supresora en ensayos de expresión de proteínas, teniendo en cuenta las características de cada uno, y que no todas las combinaciones son adecuadas.

\section{REFERENCIAS}

Anandalakshmi, R., Pruss, G. J., Ge, X., Marathe, R., Mallory, A. C., Smith, T. H. and Vance, V. B. (1998). A viral suppressor of gene silencing in plants. Proc Natl Acad Sci U $S$ A 95(22), 13079-84.

Ballut, L., Drucker, M., Pugniere, M., Cambon, F., Blanc, S., Roquet, F., Candresse, T., Schmid, H. P., Nicolas, P., Gall, O. L., and Badaoui, S. (2005). HcPro, a multifunctional protein encoded by a plant RNA virus, targets the $20 \mathrm{~S}$ proteasome and affects its enzymic activities. J Gen Virol 86(Pt 9), 2595-603. 
Bedoya, L. C., and Daros, J. A. (2010). Stability of Tobacco etch virus infectious clones in plasmid vectors. Virus Res 149(2), 234-40.

Bedoya, L., Martinez, F., Rubio, L., and Daros, J. A. (2010). Simultaneous equimolar expression of multiple proteins in plants from a disarmed potyvirus vector. J Biotechnol 150(2), 268-75.

Chiera, J. M., Lindbo, J. A., and Finer, J. J. (2008). Quantification and extension of transient GFP expression by the co-introduction of a suppressor of silencing. Transgenic Res 17(6), 1143-54.

Csorba, T., Pantaleo, V., and Burgyan, J. (2009). RNA silencing: an antiviral mechanism. Adv Virus Res 75, 35-71.

Dhillon, T., Chiera, J. M., Lindbo, J. A., and Finer, J. J. (2009). Quantitative evaluation of six different viral suppressors of silencing using image analysis of transient GFP expression. Plant Cell Rep 28(4), 639-47.

Ghazala, W., Waltermann, A., Pilot, R., Winter, S., and Varrelmann, M. (2008). Functional characterization and subcellular localization of the $16 \mathrm{~K}$ cysteine-rich suppressor of gene silencing protein of tobacco rattle virus. J Gen Viro/ 89(Pt 7), 174858.

González, I., Martínez, L., Rakitina, D. V., Lewsey, M. G., Atencio, F. A., Llave, C., Kalinina, N. O., Carr, J. P., Palukaitis, P., and Canto, T. (2010). Cucumber mosaic virus $2 \mathrm{~b}$ protein subcellular targets and interactions: their significance to RNA silencing suppressor activity. Mol Plant Microbe Interact 23(3), 294-303.

Goto, K., Kobori, T., Kosaka, Y., Natsuaki, T., and Masuta, C. (2007). Characterization of silencing suppressor $2 b$ of cucumber mosaic virus based on examination of its small RNA-binding abilities. Plant Cell Physiol 48(7), 1050-60.

Guo, H. S., and Ding, S. W. (2002). A viral protein inhibits the long range signaling activity of the gene silencing signal. EMBO J 21(3), 398-407.

Lakatos, L., Szittya, G., Silhavy, D., and Burgyan, J. (2004). Molecular mechanism of RNA silencing suppression mediated by p19 protein of tombusviruses. EMBO J 23(4), 876-84.

Lakatos, L., Csorba, T., Pantaleo, V., Chapman, E. J., Carrington, J. C., Liu, Y. P., Dolja, V. V., Calvino, L. F., Lopez-Moya, J. J., and Burgyan, J. (2006). Small RNA binding is a common strategy to suppress RNA silencing by several viral suppressors. EMBO J 25(12), 2768-80.

Lewsey, M. G., Gonzalez, I., Kalinina, N. O., Palukaitis, P., Canto, T., and Carr, J. P. (2010). Symptom induction and RNA silencing suppression by the cucumber mosaic virus 2b protein. Plant Signal Behav 5(6), 705-8.

Li, X. H., and Carrington, J. C. (1995). Complementation of tobacco etch potyvirus mutants by active RNA polymerase expressed in transgenic cells. Proc Natl Acad Sci U $S$ A 92(2), 457-61. 
Mallory, A. C., Reinhart, B. J., Bartel, D., Vance, V. B., and Bowman, L. H. (2002). A viral suppressor of RNA silencing differentially regulates the accumulation of short interfering RNAs and micro-RNAs in tobacco. Proc Natl Acad Sci U S A 99(23), 1522833.

Martínez-Priego, L., Donaire, L., Barajas, D., and Llave, C. (2008). Silencing suppressor activity of the Tobacco rattle virus-encoded $16-\mathrm{kDa}$ protein and interference with endogenous small RNA-guided regulatory pathways. Virology 376(2), 346-56.

Omarov, R., Sparks, K., Smith, L., Zindovic, J., and Scholthof, H. B. (2006). Biological relevance of a stable biochemical interaction between the tombusvirus-encoded P19 and short interfering RNAs. J Virol 80(6), 3000-8.

Pruss, G., Ge, X., Shi, X. M., Carrington, J. C., and Bowman Vance, V. (1997). Plant viral synergism: the potyviral genome encodes a broad-range pathogenicity enhancer that transactivates replication of heterologous viruses. Plant Cell 9(6), 859-68.

Reavy, B., Dawson, S., Canto, T., and MacFarlane, S. A. (2004). Heterologous expression of plant virus genes that suppress post-transcriptional gene silencing results in suppression of RNA interference in Drosophila cells. BMC Biotechnol 4, 18.

Roth, B. M., Pruss, G. J., and Vance, V. B. (2004). Plant viral suppressors of RNA silencing. Virus Res 102(1), 97-108.

Shiboleth, Y. M., Haronsky, E., Leibman, D., Arazi, T., Wassenegger, M., Whitham, S. A., Gaba, V., and Gal-On, A. (2007). The conserved FRNK box in HC-Pro, a plant viral suppressor of gene silencing, is required for small RNA binding and mediates symptom development. J Virol 81(23), 13135-48.

Siddiqui, S. A., Sarmiento, C., Kiisma, M., Koivumaki, S., Lemmetty, A., Truve, E., and Lehto, K. (2008). Effects of viral silencing suppressors on tobacco ringspot virus infection in two Nicotiana species. J Gen Virol 89(Pt 6), 1502-8.

Scholthof, H. B. (2006). The Tombusvirus-encoded P19: from irrelevance to elegance. Nat Rev Microbiol 4(5), 405-11.

Thole, V., Worland, B., Snape, J. W., and Vain, P. (2007). The pCLEAN dual binary vector system for Agrobacterium-mediated plant transformation. Plant Physiol 145(4), 1211-9.

Voinnet, O., Pinto, Y. M., and Baulcombe, D. C. (1999). Suppression of gene silencing: a general strategy used by diverse DNA and RNA viruses of plants. Proc Natl Acad Sci U S A 96(24), 14147-52.

Voinnet, O., Rivas, S., Mestre, P., and Baulcombe, D. (2003). An enhanced transient expression system in plants based on suppression of gene silencing by the p19 protein of tomato bushy stunt virus. Plant J 33(5), 949-56. 
Wang, Y., Tzfira, T., Gaba, V., Citovsky, V., Palukaitis, P., and Gal-On, A. (2004). Functional analysis of the Cucumber mosaic virus $2 \mathrm{~b}$ protein: pathogenicity and nuclear localization. J Gen Viro/ 85(Pt 10), 3135-47.

Waterhouse, P. M., Wang, M. B., and Lough, T. (2001). Gene silencing as an adaptive defence against viruses. Nature 411(6839), 834-42. 
CAPÍTULO 6. RESULTADOS:

DECONSTRUCCIÓN DEL VECTOR DE EXPRESIÓN BASADO EN EL POTYVIRUS DEL GRABADO DEL TABACO 


\section{INTRODUCCIÓN}

Los vectores virales son herramientas para la expresión de proteínas heterólogas en plantas con numerosas ventajas. Con ellos se pueden obtener mayores niveles de expresión que en plantas transgénicas, en un tiempo más corto, y el proceso completo es mucho más fácil y menos costoso, por lo que muchos virus se han empleado para producir gran variedad de proteínas recombinantes (Gleba et al., 2007). En los primeros ejemplos de construcción de vectores virales se sustituyó el gen de la proteína de cubierta (CP) viral por el gen foráneo a expresar, pero en muchos casos se comprobó que dicha proteína jugaba un papel importante en el movimiento del virus y su deleción impedía la infección sistémica de la planta (Scholthof et al., 1996). Por este motivo se adoptó la estrategia de insertar el gen de la proteína recombinante en adición al genoma viral completo. Sin embargo, una de las mayores restricciones de este tipo de vectores es el contenido de material genético exógeno que se puede insertar de forma estable sin comprometer su capacidad de infectar, replicarse en las células vegetales o moverse sistémicamente hacia otros tejidos de la planta (Cañizares et al. 2005). Como consecuencia, la necesidad de mejorar los vectores virales de expresión ha llevado a proponer estrategias diversas, basadas en la posibilidad de extraer genes del genoma viral, para ampliar su capacidad de insertar genes heterólogos, y suplementar estas funciones en trans. Por un lado, se pueden transferir genes virales a las plantas huésped para que estas cumplan su función y permitan al virus llevar a cabo correctamente todo el proceso de infección y expresión de la proteína recombinante. En algunos casos, como el descrito por Dore et al. en 1991, dicha suplementación de funciones virales en plantas transgénicas no ha sido eficiente, mientras que en otros, aunque con distintos objetivos, se han obtenido plantas que expresan eficientemente genes virales y que permiten que virus con deleciones parciales o totales en dichos genes se multipliquen y se muevan adecuadamente (Li y Carrington, 1995; Guevara-González et al, 1999). A pesar de esto, hay que tener en cuenta que la obtención de plantas transgénicas es un proceso largo y tedioso, y puede llegar a ser difícil insertar más de un gen o genes de gran tamaño. Otra estrategia que se ha empleado frecuentemente para distintos tipos de ensayos, consiste en la capacidad de complementar virus que tienen genes delecionados con otras cepas del mismo virus o con otros virus. Este fenómeno de transcomplementación ha sido descrito en ensayos como los realizados por Atabekov et al. (1999), Kumari et al. (2011) o Hiraguri et al. (2011), y es una opción interesante con altas probabilidades de 
aplicarse en la mejora de sistemas de expresión de proteínas recombinantes. Por otro lado, el desarrollo de técnicas para insertar genes, DNAs o cDNAs virales en plantas por medio de Agrobacterium tumefaciens (Grimsley et al., 1986), ha permitido perfeccionar las estrategias de deconstrucción de los vectores virales de expresión, transfiriendo algunas funciones a la bacteria, para así aumentar su eficiencia. En los trabajos de Gleba et al. (2005) y de Marillonnet et al. (2004 y 2005), se muestran las ventajas de combinar en ensayos de expresión transitoria los sistemas de transfección para insertar eficientemente material genético en plantas, basados en A. tumefaciens, y la alta acumulación de proteínas generada con los vectores virales. Además, se han investigado formas de optimizar este tipo de sistemas para producir altas cantidades de proteínas, como el uso de las 5' y 3' UTRs (regiones no traducibles) del virus del mosaico del chícharo (Cowpea mosaic virus, CPMV) o la inserción del supresor del silenciamiento P19 (Sainsbury et al., 2009).

En este trabajo se investiga la posibilidad de seguir deconstruyendo el vector de expresión basado en el virus del grabado del tabaco (TEV, género Potyvirus, familia Potyviridae) desarrollado con anterioridad (Bedoya et al., 2010), transfiriendo genes virales hacia un vector complementario que contiene la 5' y 3' UTRs del CPMV, y el cual se coinocula para suplementar la función correspondiente. Como gen reportero se empleó Rosea1, que codifica un factor de transcripción que promueve la biosíntesis de antocianinas en las plantas inoculadas, haciendo que se acumulen y permitiendo ver de color rojo las zonas donde ha ocurrido correctamente la complementación. Un análisis inicial de las condiciones de coinoculación mostró que la densidad óptica (DO) a 600 $\mathrm{nm}$ de los cultivos de $A$. tumefaciens y la hoja inoculada pueden ambos influir considerablemente en los resultados. Estos resultados mostraron que es posible eliminar, además de la Nlb que ya está delecionada en el vector, dos genes virales más (P1 y HC-Pro), los cuales son suplementados adecuadamente por un vector complementario. El gen de la CP se puede delecionar parcialmente y suplementar apropiadamente. 


\section{MATERIALES Y MÉTODOS}

\section{$\underline{\text { Construcción de plásmidos }}$}

El plásmido pTEV $\triangle$ Nlb-Ros1 contiene un cDNA infeccioso del TEV (Genbank nº DQ986288), flanqueado por el promotor y terminador 35S del CaMV (Bedoya y Darós, 2010), las mutaciones silenciosas (G273A y A1119G) para eliminar sitios de resticción Bsal internos, y el cistrón de NIb se ha reemplazado por el cDNA correspondiente a la región codificante del gen Rosea1. El plásmido pG53 es un vector derivado del pGTEV (Bedoya y Darós, 2010) en el que se ha eliminado todo el cDNA del TEV y el promotor y terminador 35S flanquean las 5' y 3' UTR del CPMV y un sitio de inserción para la expresión de proteínas con codón ATG de inicio y codón de terminación. Todas las reacciones de PCR se realizaron en $20 \mu \mathrm{l}$ con $0.4 \mathrm{U}$ de DNA polimerasa Phusion (Finnzymes) de alta fidelidad de copia en tampón HF (Finnzymes), 3\% DMSO, 0.2 mM dNTPs, $0.5 \mu \mathrm{M}$ de cada cebador y $10 \mathrm{ng}$ de DNA molde. Las reacciones se incubaron por $30 \mathrm{~s}$ a $98^{\circ} \mathrm{C}$, seguido de 30 ciclos de $10 \mathrm{~s}$ a $98^{\circ} \mathrm{C}, 30 \mathrm{~s}$ a $55^{\circ} \mathrm{C}$ y $30 \mathrm{~s}$ a $72^{\circ} \mathrm{C}, \mathrm{y}$ con una extensión final de $10 \mathrm{~min}$ a $72 \stackrel{\circ}{\circ}$. Los productos de PCR y plásmidos se trataron según las técnicas estándar basadas en el uso de la enzima de restricción tipo Ils Bsal (New England Biolabs), se ligaron con la T4 DNA ligasa (Fermentas) y se transformaron en Escherichia coli DH5a por electroporación (ECM 399, BTX). Los cebadores empleados se describen en la Tabla 6.1 suplementaria.

El plásmido pTEV $\Delta$ NIb-Ros1 se empleó para obtener por amplificación PCR y autoligación los plásmidos defectivos pTEVAP1.NIb-Ros1, pTEVAP1.HCPro.NIb-Ros1, pTEV $\triangle$ P1.HCPro.P3.NIb-Ros1, pTEVAP1.HCPro.P3.6K1.CI.NIb-Ros1 y pTEVANIb.NtCP-Ros1. En el plásmido pG53 se insertaron los cDNAS de las proteínas correspondientes, amplificadas a partir del plásmido pGTEV, para obtener los vectores complementarios pG53-NIb, pG53-P1.NIb (que conserva las 3 primeros aminoácidos de HC-Pro tras P1), pG53-P1.HCPro.NIb (que conserva los 3 primeros aminoácidos de P3 tras HC-Pro), pG53-P1.HCPro.P3.NIb, pG53-P1.HCPro.P3.6K1.CI.NIb y pG53NIb.CP. 
$\underline{\text { Inoculación de plantas }}$

Se inocularon plantas de Nicotiana benthamiana Domin de aproximadamente 5 semanas de edad, realizando un máximo de 3 infiltraciones por hoja, en distintas hojas dentro de una planta y manteniéndolas en una cámara de cultivo con un fotoperíodo de 12 h día a $25^{\circ} \mathrm{C}$ y 12 h noche a $23^{\circ} \mathrm{C}$. La agroinoculación se realizó con cultivos de Agrobacterium tumefaciens C58C1 conteniendo el plásmido auxiliar pCLEAN-S48 (Thole et al., 2007) y los plásmidos pTEV $\Delta$ NIb-Ros1, pTEV $\Delta$ P1.NIb-Ros1, pTEV $\triangle$ P1.HCPro.NIb-Ros1, pTEVAP1.HCPro.P3.NIb-Ros1, pTEVAP1.HCPro.P3.6K1.CI.NIb-Ros1, pTEVANIb.NtCP-Ros1, pG53-NIb, pG53P1.NIb, pG53-P1.HCPro.NIb, pG53-P1.HCPro.P3.NIb, pG53-P1.HCPro.P3.6K1.CI.NIb y pG53-NIb.CP, ajustados a la DO $(600 \mathrm{~nm})$ correspondiente en cada caso e inducidos a $28 \stackrel{\circ}{\mathrm{C}}$ por $2 \mathrm{~h}$ con $150 \mu \mathrm{M}$ acetosiringona como se ha descrito anteriormente (Bedoya y Darós, 2010). Inmediatamente antes de la coinoculación se mezclaron los cultivos de cada vector defectivo con su correspondiente vector complementario, en una relación 1:1. Como control para cada combinación se agroinocularon hojas con el vector defectivo sin ningún vector adicional, cuyo cultivo se mezcló con tampón de inducción.

\section{$\underline{\text { Cuantificación de antocianinas }}$}

Transcurridos 6 días de la inoculación se recogió tejido de las zonas infiltradas con las distintas combinaciones de suplementación, 4 réplicas por cada una, y se guardó a -80 ${ }^{\circ} \mathrm{C}$. El tejido congelado se homogenizó con un procesador mecánico (Tissueruptor, Qiagen) añadiendo 50 volúmenes de solución de extracción $(0.037 \% \mathrm{HCl}$ en metanol), y se mantuvo en hielo por $1 \mathrm{~h}$ con agitación ocasional para finalmente tomar una alícuota, centrifugar $5 \mathrm{~min}$ y recuperar el sobrenadante. La concentración de antocianinas se determinó midiendo los valores de absorbancia de cada muestra a 530 $\mathrm{nm}$ con un espectrofotómetro (Biochrom WPA Biowave II).

\section{$\underline{\text { Análisis estadístico }}$}

Los datos de absorbancia medidos para las distintas muestras se emplearon para hacer una análisis de varianza ANOVA multifactor, con el software STATGRAFICS Plus 5.1. Se definieron como significativos aquellos valores de $P$ inferiores a 0.05 . 


\section{RESULTADOS Y DISCUSIÓN}

Con el fin de aumentar la capacidad del vector viral de expresión desarrollado anteriormente (Bedoya et al., 2010) para introducir material genético exógeno, se planteó un ensayo de expresión transitoria basado en la deconstrucción del vector y la suplementación en trans por medio de la coinoculación con vectores complementarios en los que el gen a expresar está flanqueado por las 5' y 3' UTRs del CPMV para promover su expresión (Sainsbury y Lomonossoff, 2008). En el plásmido control el gen de Nlb se sustituyó por el gen reportero Ros1, y a partir de este se realizaron deleciones seriadas de la región $\mathrm{N}$-terminal del genoma del TEV hasta el cistrón de $\mathrm{Cl}$, o se delecionó en la región C-terminal parte de la proteína CP, generando 6 versiones del vector defectivo (Fig. 6.1A). Asímismo, para construir los 6 vectores complementarios, se insertaron secuencialmente a partir del control que expresa Nlb las secuencias de las proteínas delecionadas (Fig. 6.1B).

En primer lugar, se realizó con la combinación control (pTEVANlb-Ros1 + pG53-Nlb) un estudio preliminar para estandarizar las condiciones en que debía realizarse el ensayo de expresión transitoria en plantas de $N$. benthamiana. Para ello, se prepararon los diferentes cultivos de $A$. tumefaciens, llevando tanto los vectores defectivos como los complementarios a DO $(600 \mathrm{~nm})$ desde 0.0625 hasta 2 . Hay que tener en cuenta que los cultivos se llevaron inicialmente al doble de la DO (600 nm) que en la mezcla final. Al agroinocular hojas de $N$. benthamiana con los cultivos a diversas DO, y hacer una cuantificación de las antocianinas acumuladas transcurridos 6 días de la inoculación, se vió que a mayores DO hay una mayor acumulación de antocianinas, obteniéndose los valores más altos con una DO de aproximadamente 1 (Fig. 6.2A). De forma similar, y una vez escogida una DO de 1, se estudió en que tipo de tejido se observan los resultados de la suplementación más claramente, coinoculando los cultivos control en 6 hojas distintas dentro de una misma planta. Los resultados mostraron que es conveniente inocular las dos hojas más jóvenes, ya que en estas se obtuvieron los valores más altos reflejando una mejor acumulación de las antocianinas que en las hojas basales (Fig. 6.2B). 
A
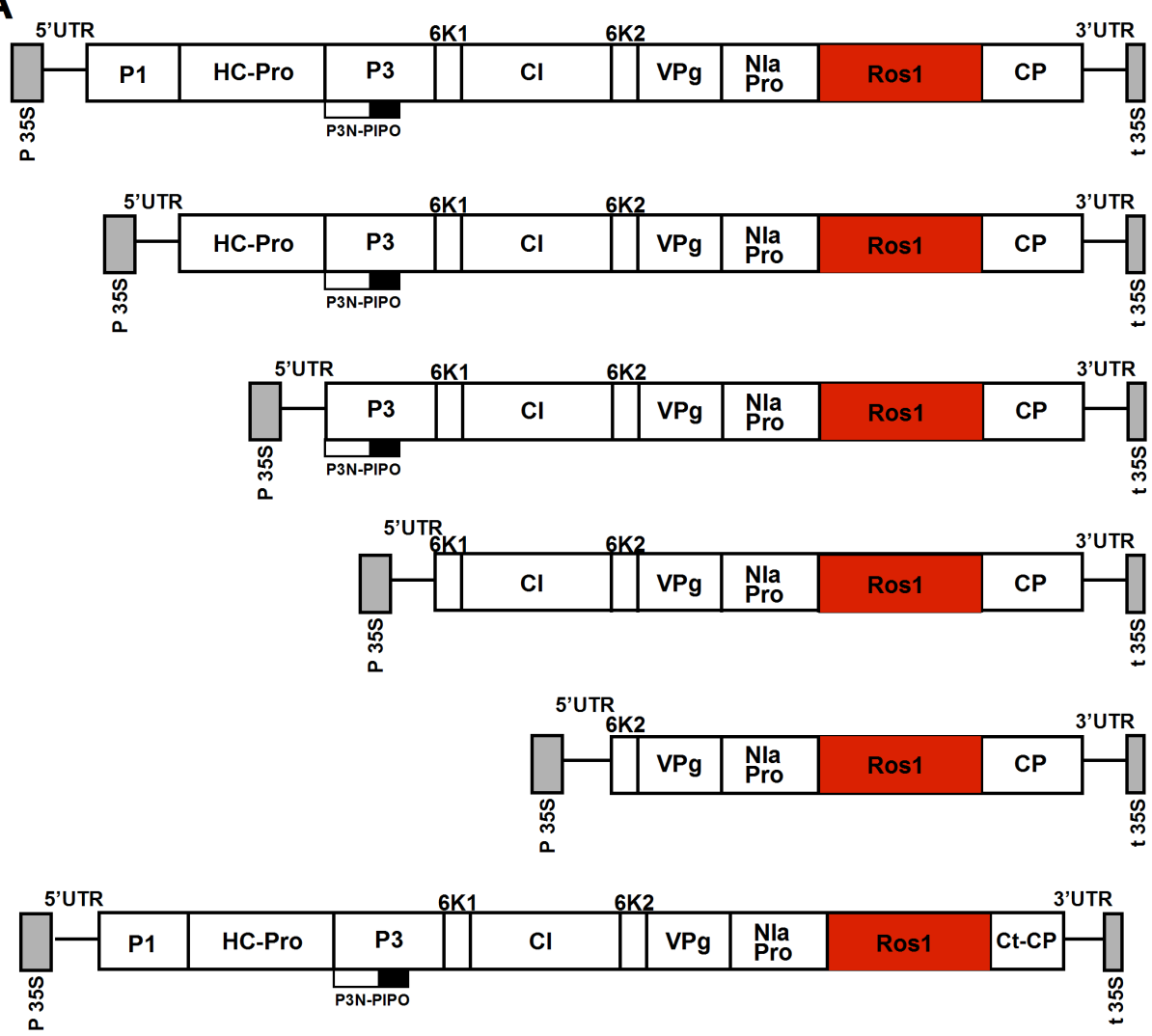

B

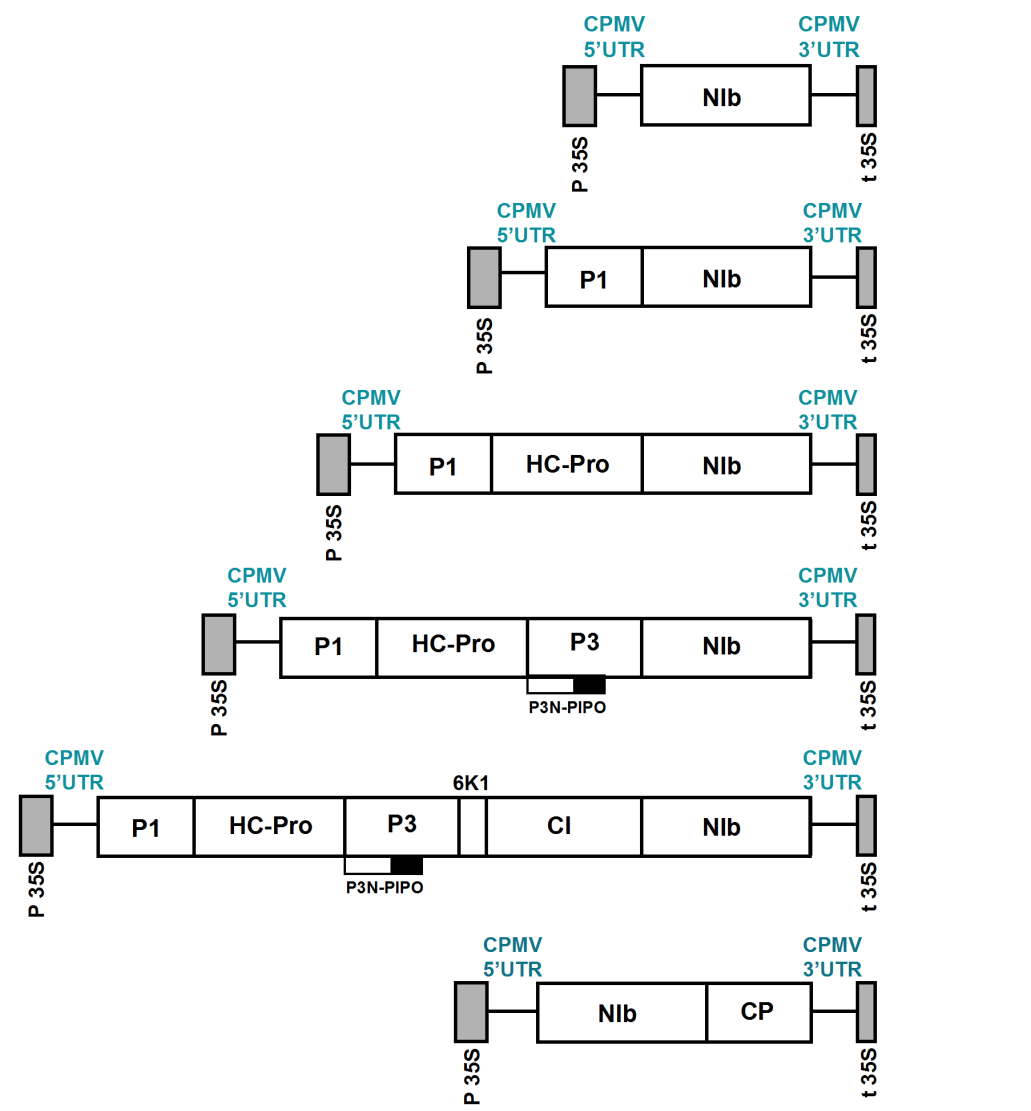

Figura 6.1. Esquema de las distintas construcciones empleadas en el estudio de la deconstrucción del vector viral. (A) En el vector se reemplazó Nlb con el gen reportero Rosea1 y se hicieron deleciones secuenciales de P1, HC-Pro, P3, 6K1+ Cl y la región amino terminal (Nt) de CP. (B) Vectores complementarios consistentes en las proteínas a suplementar flanqueadas por la 5' y 3' UTRs del CPMV. 
A.

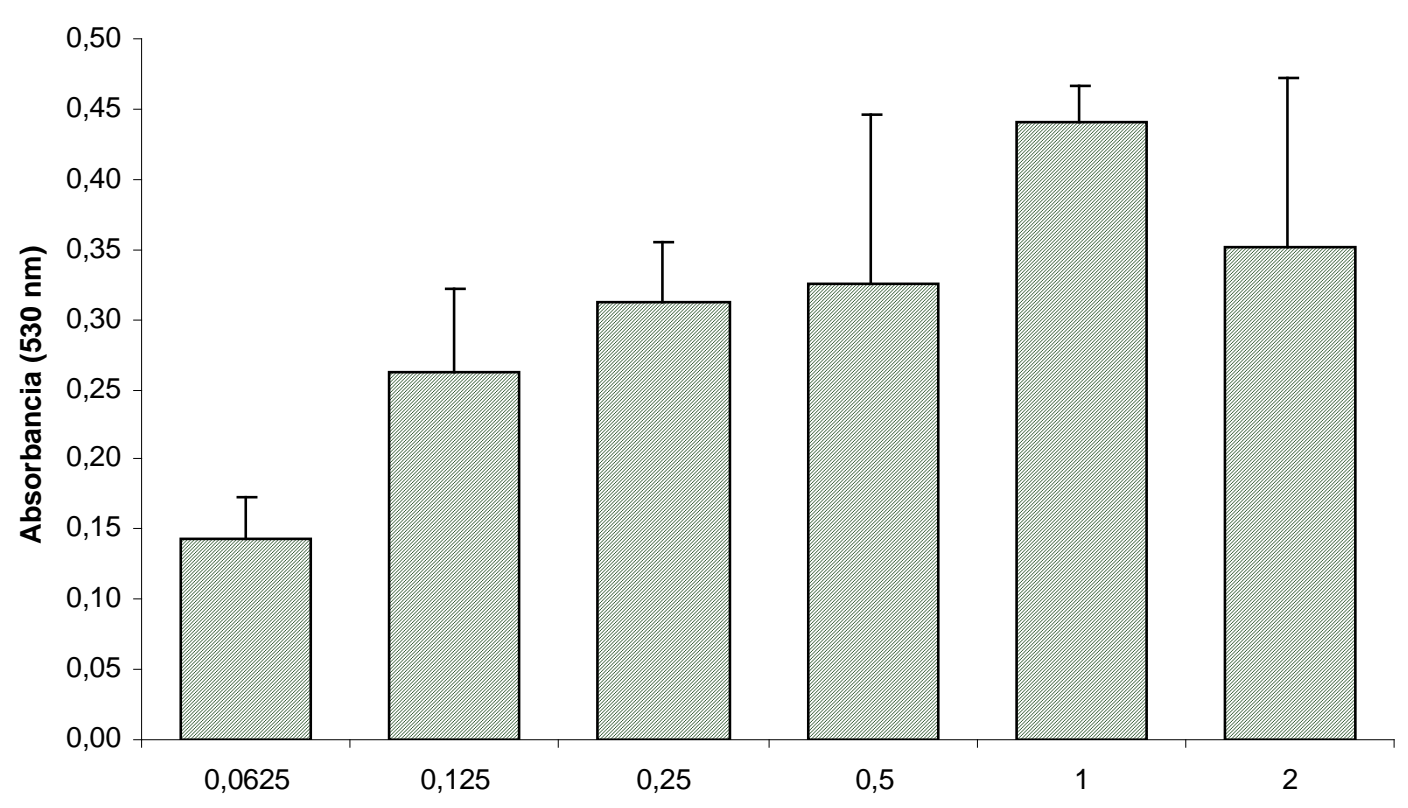

B.

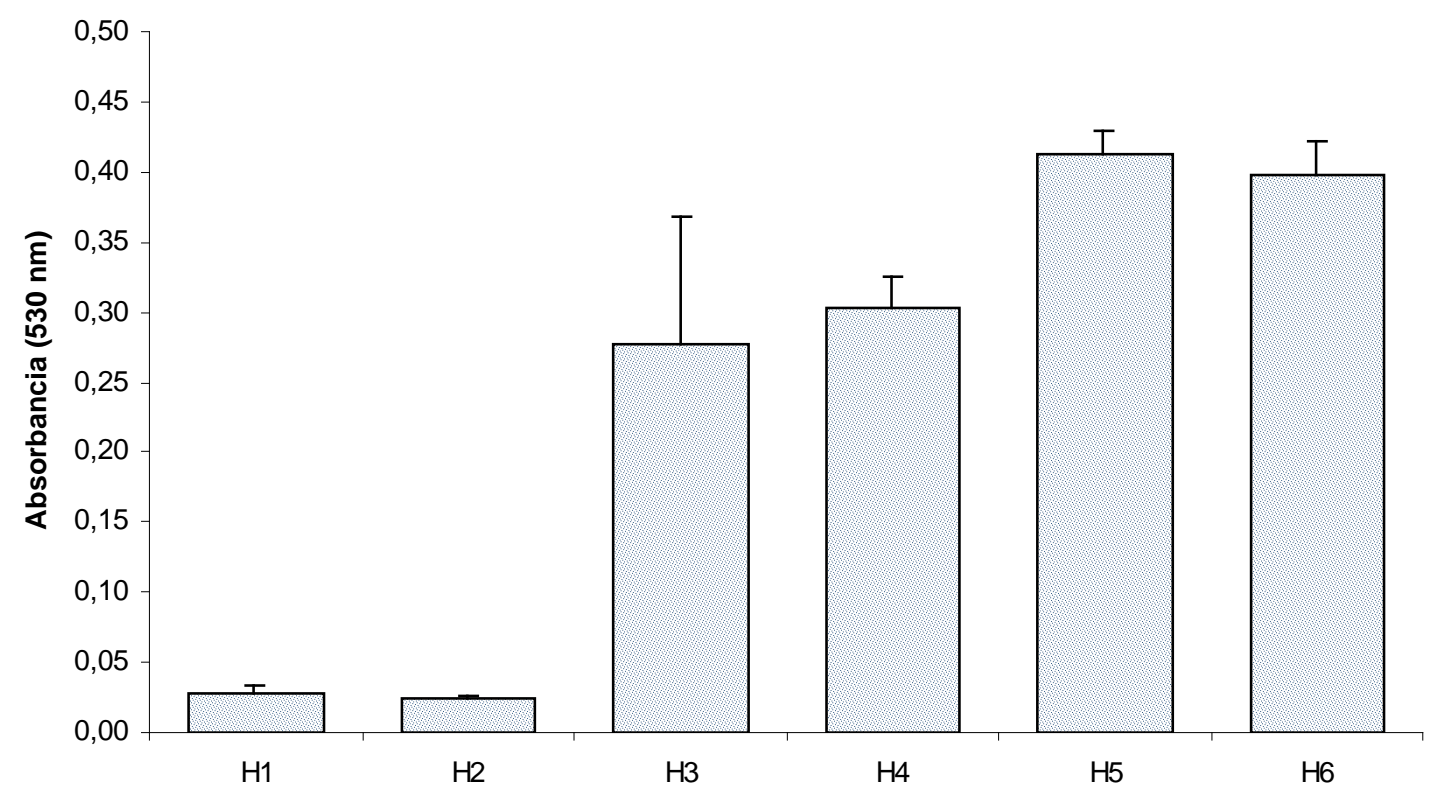

Figura 6.2. Acumulación de antocianinas en tejido agroinoculado de $N$. benthamina en diferentes condiciones de estudio. (A) Efecto de la DO $(600 \mathrm{~nm})$ de los cultivos de $A$. tumefaciens. Se agroinocularon cultivos de la bacteria con lo plásmidos pTEV $\Delta \mathrm{Nlb}-\mathrm{Ros} 1+$ pG53-NIb a DO de 0.0625, 0.125, 0.25, 0.5, y 2. (B) Efecto de la hoja agroinoculada de $N$. benthamiana en una misma planta. Se agroinocularon seis hojas distintas desde la más adulta (H1) hasta la más joven (H6). En todos los casos se muestran los valores de absorbancia a 530 $\mathrm{nm}$ promedio para $4(\mathrm{~A})$ y $3(\mathrm{~B})$ réplicas, así como el error estándar. 
Una vez se determinaron las condiciones en que se debía realizar el estudio, se hicieron las inoculaciones con las 6 posibles combinaciones de vectores defectivos y vectores complementarios de la siguiente manera:

$$
\begin{aligned}
& \mathrm{C} 1=\mathrm{TEV} \Delta \mathrm{Nlb}-\mathrm{Ros} 1+\mathrm{pG} 53-\mathrm{Nlb} \\
& \mathrm{C} 2=\mathrm{TEV} \Delta \mathrm{P} 1 . \mathrm{NIb}-\mathrm{Ros} 1+\mathrm{pG} 53-\mathrm{P} 1 . \mathrm{Nlb} \\
& \text { C3 = TEVAP1.HCPro.NIb-Ros1 + pG53-P1.HCPro.NIb } \\
& \text { C4 = TEVAP1.HCPro.P3.NIb-Ros1 + pG53-P1.HCPro.P3.NIb } \\
& \text { C5 = TEVAP1.HCPro.P3.6K1.CI.NIb-Ros1 + pG53-P1.HCPro.P3.6K1.CI.NIb } \\
& \text { C6 = TEVANIb.NtCP-Ros1 + pG53-NIb.CP }
\end{aligned}
$$

Como un control adicional se realizó la inoculación con el vector pG53-NIb, el cual no expresa el gen Ros1, de manera que sus valores de absorbancia a $530 \mathrm{~nm}$ pueden atribuirse a otros factores distintos a la expresión del gen reportero y consecuente acumulación de antocianinas. A los valores de absorbancia obtenidos con las distintas coinoculaciones y sus respectivos controles se restó el valor promedio de dicho control.

Al extraer y cuantificar las antocianinas acumuladas en las zonas agroinfiltradas, tanto para las inoculaciones control con los vectores defectivos solos como para las coinoculaciones, se observaron diferentes patrones para cada caso (Fig 6.3). Solamente en las coinoculaciones con los vectores con una deleción única C1 y C6, y con el vector defectivo en 3 proteínas C3, se observaron valores más altos para la coinoculación que para el control, sugiriendo que en estos casos ocurre una correcta suplementación. En la coinoculación C2, con el vector que tiene delecionadas P1 y NIb, aunque el valor control se encuentra ligeramente por debajo, los bajos valores de absorbancia tanto para el control como para la coinoculación parecen indicar que no ocurre la complementación. Finalmente, en las coinoculaciones C4 y C5 se obtuvieron valores para los controles incluso mayores que para la coinoculación, indicando que en casos donde el vector tiene delecionados de 4 a 6 cistrones puede producirse la expresión transitoria del gen reportero sin necesidad de que haya suplementación por parte de un vector complementario. 


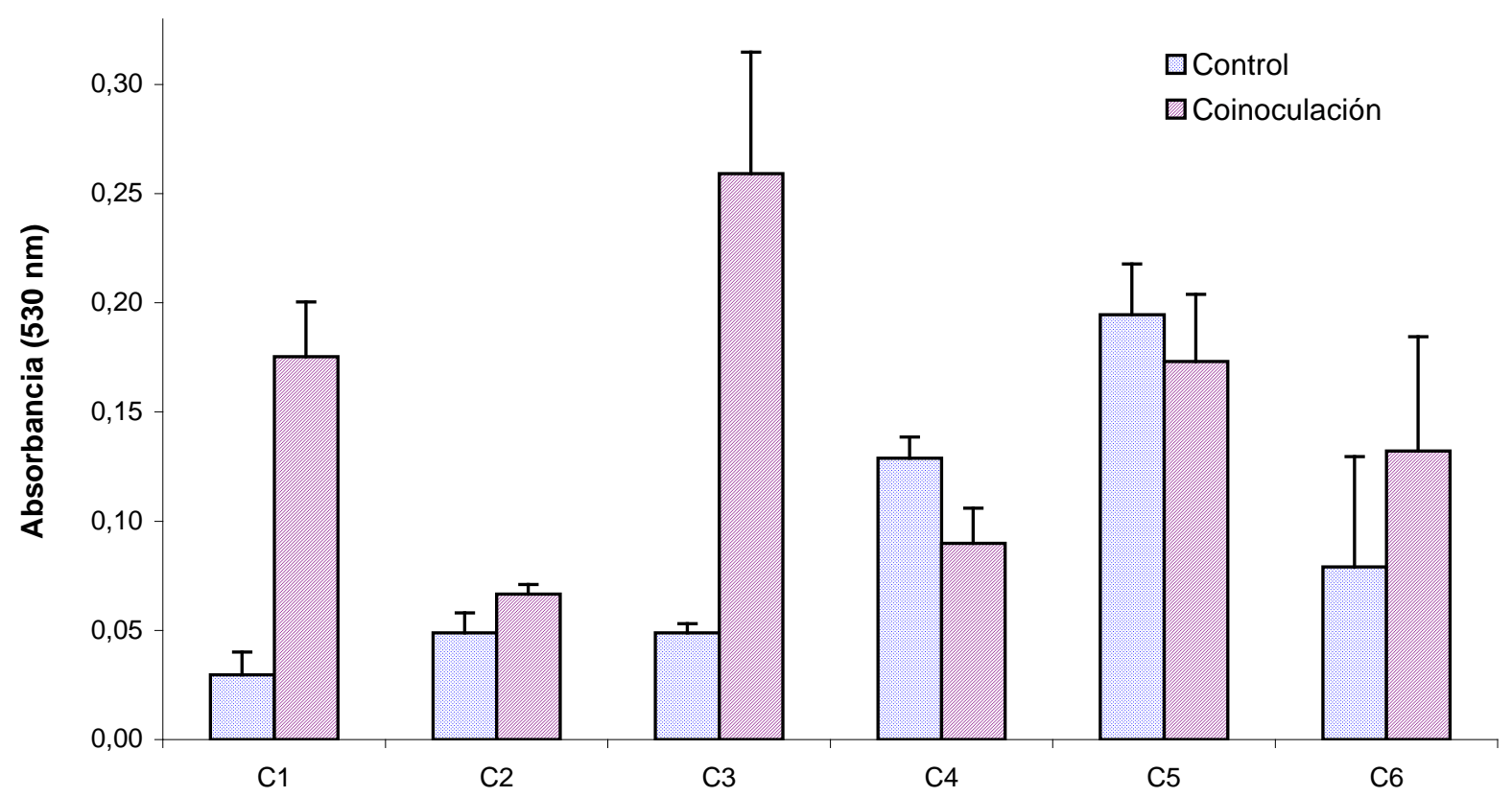

Figura 6.3. Cuantificación de antocianinas a partir de tejido de $N$. benthamiana coinfiltrado con diferentes combinaciones de cultivos. C1: TEVANIb-Ros1 +pG53-NIb, C2: TEVAP1.NIbRos1+pG53-P1.NIb, C3: TEVAP1.HCPro.Nlb-Ros1+pG53-P1.HCPro.Nlb, C4: TEVAP1.HCPro.P3.Nlb-Ros1 + pG53-P1. HCPro.P3.Nlb, C5: TEVAP1.HCPro.P3.6K1.CI.NIbRos1+pG53-P1.HCPro. P3. 6K1.CI.NIb, C6: TEVANIb.NtCP-Ros1+pG53-Nlb.CP. Se muestran los valores promedio de 4 réplicas tanto para cada control (vector viral solo) como cada coinoculación, y su error estándar.

Un análisis de varianzas realizado con los datos de absorbancia, mostró que de los 3 casos identificados inicialmente, las únicas diferencias significativas entre el control y la coinoculación se dieron con el vector que tiene delecionada Nlb (C1) y con el que tiene delecionadas P1, HC-Pro e Nlb (C3) (Fig. 6.4). En el caso de Nlb, la deleción de partida, estos resultados corroboran la posibilidad de suplementar esta proteína en trans por medio del vector de agroinoculación, de forma similar a lo que ocurre cuando se suplementa con un transgen como se ha descrito anteriormente por Li y Carrington (1995). Por otro lado, es curioso que no haya ocurrido una correcta suplementación para el vector defectivo en P1 y Nlb (C2), pero que esta sí haya ocurrido adecuadamente con el vector defectivo en P1, HC-Pro y Nlb, sugiriendo que las proteínas P1 y HC-Pro por algún motivo deben estar delecionadas simultáneamente para un correcto funcionamiento del vector de suplementación. No se esperan problemas en el procesamiento de las proteínas en estos dos vectores complementarios ya que se añadieron tres aminoácidos de HC-Pro y de P3 para completar el autoprecesamiento de P1 y Hc-Pro, respectivamente. Este resultado es importante, ya que refleja la posibilidad de delecionar cistrones adicionales al vector 
defectivo de expresión y, además, es la base para pensar en desarrollar en un futuro plantas transgénicas que expresen las tres proteínas virales, de modo que el vector de expresión tenga una mejor capacidad de insertar material genético foráneo y se pueda contar con un sistema de suplementación en trans mucho más estable.

En el caso de la suplementación del vector que tiene, además de Nlb, una deleción parcial en el gen de la proteína de cubierta, aunque hubo diferencias en los valores de absorbancia entre el control y la mezcla, dicha diferencia no resultó ser significativa en el análisis estadístico, reflejando una deficiente suplementación. Este resultado puede sugerir que, aunque se han descrito regiones dentro de la CP vitales para el funcionamiento del virus y otras que no (Mahajan et al., 1996), puede que en estudios de suplementación en trans como este no sea aconsejable realizar modificaciones o deleciones de esta proteína debido a su importante papel en la encapsidación de las partículas virales o el movimiento.

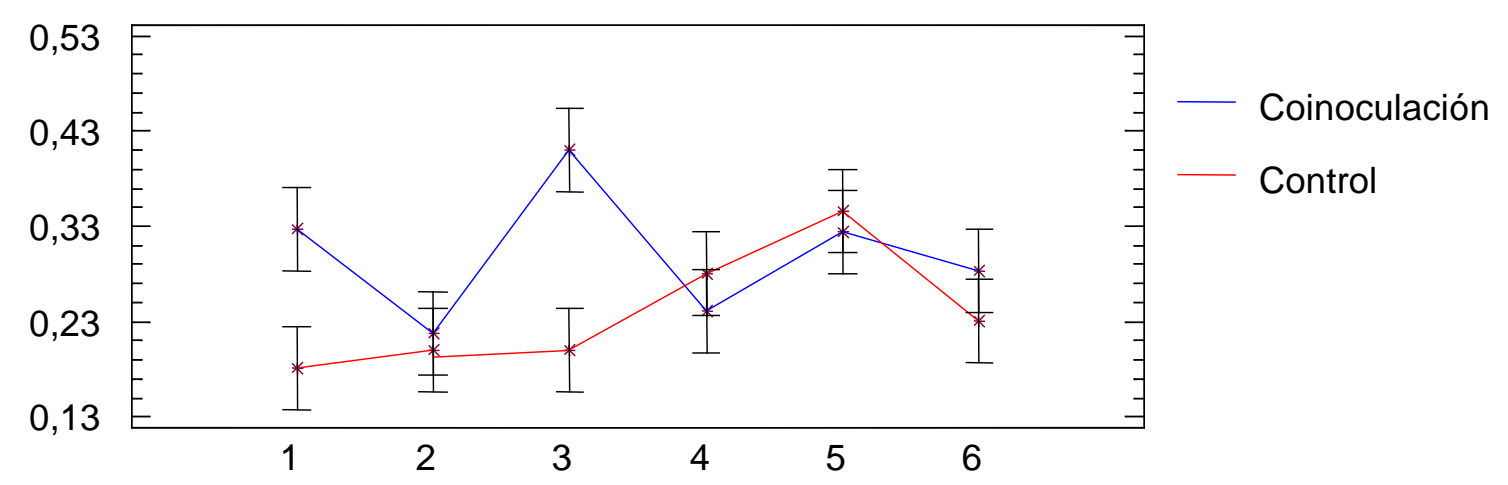

Figura 6.4. Representación gráfica del análisis de varianza realizado con los valores de absorbancia medidos para cada combinación. Se muestran las diferencias entre cada control (línea roja) y su correspondiente mezcla (línea azul).

Proteínas como P1, HC-Pro y P3 se han transferido a plantas con éxito para distintos tipos de estudios de biología básica, análisis de resistencia o ensayos de sinergismo con los potyvirus (Verchot y Carrington, 1995; Vance et al., 1995; Moreno et al., 1998), así como algunas proteínas de otros virus también se han podido complementar en trans (Lough et al., 2001). En la mayoría de esos casos se ha estudiado la posibilidad de suplementar genes individuales, mientras que en el presente estudio se comprobó que es posible suplementar en trans más de un gen del TEV. Estos resultados reflejan el potencial que existe de utilizar versiones defectivas del vector de expresión para 
insertar un mayor número de genes heterólogos o genes de mayor tamaño, y así intentar superar las típicas limitaciones existentes en los vectores de expresión de proteínas de este tipo, impuestas por el tamaño (Gleba et al., 2007), sin descartar posibles aplicaciones en otro tipo de estudios de tipo básico.

En lo referente a las metodologías empleadas en estudios de transcomplementación, se pueden dividir generalmente en tres tipos. La primera y más común es la inserción de un gen viral en plantas, como la CP o la proteína del movimiento, y que se ha empleado mayoritariamente para realizar ensayos de resistencia a virus (Prins et al., 2008). Una segunda aproximación es crear virus híbridos funcionales, que expresen genes virales heterólogos de interés, y que suplementen adecuadamente al virus correspondiente cuando se coinoculan con él (Huppert et al., 2002). En tercer lugar, se encuentran los ensayos de expresión transitoria, en los que el gen viral se inserta en las plantas junto con el virus delecionado, a través de técnicas como, por ejemplo, el cobombardeo (Agranovsky et al., 1998). Este último caso se aplicó en el estudio realizado aquí, encontrandose que dichos ensayos de expresión transitoria basados en la alta capacidad de Agrobacterium tumefaciens de transferir material genético a las células vegetales representan una metodología adecuada para hacer una evaluación rápida y relativamente sencilla de la capacidad de suplementar funciones virales a vectores defectivos en algunos de sus genes.

\section{REFERENCIAS}

Agranovsky, A. A., Folimonov, A. S., Folimonova, S., Morozov, S., Schiemann, J., Lesemann, D., and Atabekov, J. G. (1998). Beet yellows closterovirus HSP70-like protein mediates the cell-to-cell movement of a potexvirus transport-deficient mutant and a hordeivirus-based chimeric virus. J Gen Virol 79(Pt 4), 889-95.

Atabekov, J. G., Malyshenko, S. I., Morozov Yu, S., Taliansky, M. E., Solovyev, A. G., Agranovsky, A. A., and Shapka, N. A. (1999). Identification and study of tobacco mosaic virus movement function by complementation tests. Philos Trans $R$ Soc Lond B Biol Sci 354(1383), 629-35.

Bedoya, L. C., and Daros, J. A. (2010). Stability of Tobacco etch virus infectious clones in plasmid vectors. Virus Res 149(2), 234-40.

Bedoya, L., Martinez, F., Rubio, L., and Daros, J. A. (2010). Simultaneous equimolar expression of multiple proteins in plants from a disarmed potyvirus vector. $J$ Biotechnol 150(2), 268-75. 
Cañizares, M. C., Nicholson, L., and Lomonossoff, G. P. (2005). Use of viral vectors for vaccine production in plants. Immunol Cell Bio/83(3), 263-70.

Dore, J. M., van Dun, C. M., Pinck, L., and Bol, J. F. (1991). Alfalfa mosaic virus RNA3 mutants do not replicate in transgenic plants expressing RNA3-specific genes. $J$ Gen Virol 72(Pt 2), 253-8.

Gleba, Y., Klimyuk, V., and Marillonnet, S. (2005). Magnifection--a new platform for expressing recombinant vaccines in plants. Vaccine 23(17-18), 2042-8.

Gleba, Y., Klimyuk, V., and Marillonnet, S. (2007). Viral vectors for the expression of proteins in plants. Curr Opin Biotechnol 18(2), 134-41.

Grimsley, N., Hohn, B., Hohn, T., and Walden, R. (1986). "Agroinfection," an alternative route for viral infection of plants by using the Ti plasmid. Proc Natl Acad Sci U S A 83(10), 3282-6.

Guevara-González, R. G., Ramos, P. L., and Rivera-Bustamante, R. F. (1999). Complementation of coat protein mutants of pepper huasteco geminivirus in transgenic tobacco plants. Phytopathology 89(7), 540-5.

Hiraguri, A., Netsu, O., Shimizu, T., Uehara-lchiki, T., Omura, T., Sasaki, N., Nyunoya, H., and Sasaya, T. (2011). The nonstructural protein pC6 of rice grassy stunt virus trans-complements the cell-to-cell spread of a movement-defective tomato mosaic virus. Arch Virol 156(5), 911-6.

Huppert, E., Szilassy, D., Salanki, K., Diveki, Z., and Balazs, E. (2002). Heterologous movement protein strongly modifies the infection phenotype of cucumber mosaic virus. J Virol 76(7), 3554-7.

Kasschau, K. D., and Carrington, J. C. (1998). A counterdefensive strategy of plant viruses: suppression of posttranscriptional gene silencing. Cell 95(4), 461-70.

Kumari, P., Singh, A. K., Sharma, V. K., Chattopadhyay, B., and Chakraborty, S. (2011). A novel recombinant tomato-infecting begomovirus capable of transcomplementing heterologous DNA-B components. Arch Virol 156(5), 769-83.

Li, X. H., and Carrington, J. C. (1995). Complementation of tobacco etch potyvirus mutants by active RNA polymerase expressed in transgenic cells. Proc Natl Acad Sci U $S$ A 92(2), 457-61.

Lough, T. J., Emerson, S. J., Lucas, W. J., and Forster, R. L. (2001). Transcomplementation of long-distance movement of White clover mosaic virus triple gene block (TGB) mutants: phloem-associated movement of TGBp1. Virology 288(1), 18-28.

Marillonnet, S., Giritch, A., Gils, M., Kandzia, R., Klimyuk, V., and Gleba, Y. (2004). In planta engineering of viral RNA replicons: efficient assembly by recombination of DNA modules delivered by Agrobacterium. Proc Natl Acad Sci U S A 101(18), 6852-7. 
Marillonnet, S., Thoeringer, C., Kandzia, R., Klimyuk, V., and Gleba, Y. (2005). Systemic Agrobacterium tumefaciens-mediated transfection of viral replicons for efficient transient expression in plants. Nat Biotechnol 23(6), 718-23.

Moreno, M., Bernal, J. J., Jimenez, I., and Rodriguez-Cerezo, E. (1998). Resistance in plants transformed with the P1 or P3 gene of tobacco vein mottling potyvirus. $J$ Gen Virol 79(Pt 11), 2819-27.

Prins, M., Laimer, M., Noris, E., Schubert, J., Wassenegger, M., and Tepfer, M. (2008). Strategies for antiviral resistance in transgenic plants. Mol Plant Pathol 9(1), 73-83.

Sainsbury, F., Thuenemann, E. C., and Lomonossoff, G. P. (2009). pEAQ: versatile expression vectors for easy and quick transient expression of heterologous proteins in plants. Plant Biotechnol J 7(7), 682-93.

Sainsbury, F., and Lomonossoff, G. P. (2008). Extremely high-level and rapid transient protein production in plants without the use of viral replication. Plant Physiol 148(3), 1212-8.

Scholthof, H. B., Scholthof, K. B., and Jackson, A. O. (1996). Plant virus gene vectors for transient expression of foreign proteins in plants. Annu Rev Phytopathol 34, 299323.

Thole, V., Worland, B., Snape, J. W., and Vain, P. (2007). The pCLEAN dual binary vector system for Agrobacterium-mediated plant transformation. Plant Physiol 145(4), 1211-9.

Vance, V. B., Berger, P. H., Carrington, J. C., Hunt, A. G., and Shi, X. M. (1995). 5' proximal potyviral sequences mediate potato virus $X /$ potyviral synergistic disease in transgenic tobacco. Virology 206(1), 583-90.

Verchot, J., and Carrington, J. C. (1995). Evidence that the potyvirus P1 proteinase functions in trans as an accessory factor for genome amplification. $J$ Virol 69(6), 366874. 



\section{MATERIAL SUPLEMENTARIO}

Tabla 6.1. Cebadores empleados para la construcción de los distintos vectores deconstruídos y sus correspondientes vectores complementarios. Sitios Bsal subrayados.

\begin{tabular}{|c|c|c|}
\hline PLÁSMIDO & CEBADOR 1 & CEBADOR 2 \\
\hline TEV $\Delta \mathrm{P} 1$. NIb-Ros 1 & $\begin{array}{l}\text { GGCGGGTCTCCCATGGCTAT } \\
\text { CGTTCGTAAATGG }\end{array}$ & $\begin{array}{l}\text { GGCGGGTCTCCCATGAGCGA } \\
\text { CAAATCAATCTCTGAG }\end{array}$ \\
\hline TEV $\Delta$ P1.HCPro.NIb-Ros1 & $\begin{array}{l}\text { GGCGGGTCTCCCATGGCTAT } \\
\text { CGTTCGTAAATGG }\end{array}$ & $\begin{array}{l}\text { GGCGGGTCTCCCATGGGGAT } \\
\text { GAACCGAGATATGGTC }\end{array}$ \\
\hline TEVAP1.HCPro.P3.NIb-Ros1 & $\begin{array}{l}\text { GGCGGGTCTCCCATGGCTAT } \\
\text { CGTTCGTAAATGG }\end{array}$ & $\begin{array}{l}\text { GGCGGGTCTCCCATGGCAAA } \\
\text { ACAACCGGAGATAGC }\end{array}$ \\
\hline TEV $\Delta$ P1.HCPro.P3.6K1.CI.Nlb-Ros1 & $\begin{array}{l}\text { GGCGGGTCTCCCATGGCTAT } \\
\text { CGTTCGTAAATGG }\end{array}$ & $\begin{array}{l}\text { GGCGGGTCTCCCATGTCAGA } \\
\text { TAGCGAAGTGGCTAAG }\end{array}$ \\
\hline TEVANIb.NtCP-Ros1 & $\begin{array}{l}\text { GGCGGGTCTCCTCAATTTCC } \\
\text { AATTTGTTGGGCCTC }\end{array}$ & $\begin{array}{l}\text { GGCGGGTCTCCTTGAATGAG } \\
\text { TTTGTCACGCTATGC }\end{array}$ \\
\hline pG53-NIb & $\begin{array}{l}\text { GGCGGGTCTCGTGAAATGGG } \\
\text { GGAGAAGAGGAAATGGGTC }\end{array}$ & $\begin{array}{l}\text { CCGCGGTCTCCAGAGTTACT } \\
\text { GAAAATAAAGATTCTCAG }\end{array}$ \\
\hline pG53-P1.NIb & $\begin{array}{l}\text { GGCGGGTCTCGTGAAATGGC } \\
\text { ACTCATCTTTGGCAC }\end{array}$ & $\begin{array}{l}\text { CCGCGGTCTCCCCCCTTTGT } \\
\text { CGCTATAATGGGGAGATTC }\end{array}$ \\
\hline pG53-P1.HCPro.NIb & $\begin{array}{l}\text { GGCGGGTCTCGTGAAATGGC } \\
\text { ACTCATCTTTGGCAC }\end{array}$ & $\begin{array}{l}\text { CCGCGGTCTCCCCCCGTTCA } \\
\text { TCCСTCCAACATTGTAAG }\end{array}$ \\
\hline pG53-P1.HCPro.P3.NIb & $\begin{array}{l}\text { GGCGGGTCTCGTGAAATGGC } \\
\text { ACTCATCTTTGGCAC }\end{array}$ & $\begin{array}{l}\text { CCGCGGTCTCCCCCCCTGTT } \\
\text { CAACGAGGTCTTCC }\end{array}$ \\
\hline pG53-P1.HCPro.P3.6K1.CI.NIb & $\begin{array}{l}\text { GGCGGGTCTCGTGAAATGGC } \\
\text { ACTCATCTTTGGCAC }\end{array}$ & $\begin{array}{l}\text { CCGCGGTCTCCCCCCTTGGA } \\
\text { GATAGATAGTTTCCAG }\end{array}$ \\
\hline pG53-NIb.CP & $\begin{array}{l}\text { GGCGGGTCTCGTCAGAGTGG } \\
\text { CACTGTGGGTGCTGG }\end{array}$ & $\begin{array}{l}\text { CCGCGGTCTCCAGAGTCACT } \\
\text { GGCGGACCCCTAATAG }\end{array}$ \\
\hline
\end{tabular}


CAPITULO 7. RESULTADOS:

ROSEA1 COMO MARCADOR VISUAL PARA SEGUIR LA INFECCIÓN Y MOVIMIENTO DE VIRUS EN PLANTAS 
In preparation

\section{Visual tracking of plant virus infection and movement using a reporter MYB transcription factor that activates anthocyanin biosynthesis}

\section{Leonor C. Bedoya, Fernando Martínez, Diego Orzáez, José-Antonio Daròs}

Instituto de Biología Molecular y Celular de Plantas (Consejo Superior de Investigaciones Científicas - Universidad Politécnica de Valencia), Avenida de los Naranjos, 46022 Valencia, Spain

\section{ABSTRACT}

Insertion of reporter genes into plant virus genomes is a common experimental strategy to research many aspects of the viral infection dynamics. Their numerous advantages make fluorescent proteins the markers of choice in most studies. However, the use of fluorescent proteins still has some limitations, such as the need of specialized material and facilities to detect the fluorescence. Here, we demonstrate a visual reporter marker system to track virus infection and movement through the plant. The reporter system is based on expression of Antirrhinum majus MYB-related Rosea1 (Ros1) transcription factor (220 amino acids, $25.7 \mathrm{kDa}$ ) that activates a series of biosynthetic genes leading to accumulation of colored anthocyanins. Using two different tobacco etch potyvirus recombinant clones tagged with Ros1, we show that infected tobacco tissues turn bright red, demonstrating that in this context the sole expression of Ros 1 is sufficient to induce pigment accumulation to a level readily detectable to the naked eye. This marker system also reports viral load qualitatively and quantitatively by means of a very simple extraction process. The Ros1 marker remained stable within the potyvirus genome through successive infectious passages from plant to plant. The main limitation of this marker system is that color output will depend on each particular plant host-virus combination and must be previously tested. However, our experiments demonstrate accurate tracking of turnip mosaic potyvirus infecting Arabidopsis thaliana and either tobacco mosaic virus or potato $X$ virus infecting Nicotiana benthamiana, stressing the general applicability of the method.

\section{INTRODUCTION}

Research in plant virology has benefited tremendously from the use of genetically encoded reporter genes (Tilsner and Oparka, 2010). Some markers, when inserted into the viral genome, report on virus infection and movement through the plant. Others, 
when fused to a viral gene product, report on subcellular localization of that particular viral factor. The bacterial gene coding for the enzyme $\beta$-glucuronidase (GUS) was used in pioneering studies (Chapman et al., 1992; Dolja et al., 1992; Scholthof et al., 1993). GUS accumulation in the plant cells in which viral expression was taking place showed the extension of infection throughout the plant. However, GUS is not a vital marker and detection of GUS activity usually requires of destructive techniques. In contrast, the use of fluorescent protein markers as Aequorea victoria green fluorescent protein (GFP), or any of its multiple derivatives and relatives (Day and Davidson, 2009), allows marker detection in live tissues (Baulcombe et al., 1995). Moreover combination of different fluorescent marker proteins with appropriate spectral properties permits co-visualization of several viral factors at the same time as well as co-localization of viral and host factors (Caplan et al., 2008; Martin et al., 2009; Wei et al., 2010; Wei et al., 2010). Techniques such as fluorescence resonance energy transfer (FRET) and bimolecular fluorescence complementation (BiFC), also based on the use of fluorescent proteins, reveal protein-protein interactions (Citovsky et al., 2006; Piston and Kremers, 2007; Lalonde et al., 2008). Recently, a new fluorescent marker protein (iLOV) derived from a domain of Arabidopsis thaliana L. blue light receptor phototropin, was shown to offer some advantages over the GFP-derived markers as a reporter of plant virus infection and movement, and when fused to proteins, mainly based on its smaller size (Chapman et al., 2008).

The current reporter technologies based on fluorescent proteins require specialized equipment for tracking viral dynamics (e.g. UV lamps), usually involving the transfer of the plants to laboratory facilities and often requiring dissecting adult plant organs for observation. This imposes limitations to the study of viral dynamics in the whole plant, particularly in field experiments or at the agronomic scale. To deal with these limitations, we propose the use of a vital visual reporter marker system based on the activation of endogenous anthocyanin biosynthetic pathways.

Anthocyanins are plant endogenous pigments with multiple roles, from adaptation to biotic and abiotic stress to cellular recycling or attraction of seed dispersers (ChalkerScott, 1999; Ougham et al., 2005; Winefield et al., 2009). Small variations in their basic chemical composition give rise to a wide range of patterns of light absorption, which constitutes the basis of, for example, flower colors in many species (He et al., 2011), but also provide a versatile tracking tool in plant biotechnology (Orzaez et al., 2009). The biosynthesis of anthocyanins has been extensively studied, and it is known to be 
activated at the transcriptional level by a triad of transcription factors, namely an R2R3 MYB, a basic helix-loop-helix (bHLH) and a WD40 repeat protein, binding cooperatively to the promoter regions of the genes coding for the different enzymes in the pathway (Hichri et al., 2011). The overexpression of at least some of the components of the triad, usually an R2R3 MYB and a bHLH, has been used to activate anthocyanin biosynthesis (Ververidis et al., 2007). In an outstanding example, anthocyanin accumulation was induced to impressive levels in tomato (Solanum lycopersicum L.) fruits by overexpression of the Antirrhinum majus L. (garden snapdragon) transcription factors Rosea1 (Ros1) and Delila, an R2R3 MYB and a bHLH respectively (Butelli et al., 2008; Luo et al., 2008).

In our previous work aimed at testing the potential use of a disarmed potyvirus-based expression vector for multigene expression in plants, we showed that co-expression of Ros1 along with its interacting partner Delila induced accumulation of red anthocyanins in infected tobacco (Nicotiana tabacum L.) tissue (Bedoya et al., 2010). This result stimulated us to research the utility of these transcription factors as vital visual markers to track plant virus infection and movement through the host. Since an ideal reporter system must keep exogenous sequences to a minimum to avoid a strong influence on viral fitness, we have focused on the 660-nt long open reading frame (ORF) corresponding to the $A$. majus gene Rosea1, encoding a 220-amino acid (25.7-kDa) MYB-related transcription factor (Schwinn et al., 2006). Here, we show that Ros1 is sufficient to serve as a reporter for color-based tracking of viral infection and movement in several plant virus-host combinations.

\section{RESULTS}

We constructed two recombinant Tobacco etch virus (TEV, genus Potyvirus, family Potyviridae) cDNAs, both including an additional cistron coding for Ros1. Two classic insertion positions for potyviruses were chosen (Dolja et al., 1992; Beauchemin et al., 2005; Kelloniemi et al., 2008). The first, located between P1 proteinase (P1) and helpercomponent proteinase (HC-Pro) cistrons, generated recombinant clone TEVRos1(P1/HC-Pro) (Fig. 1a). The second, between the RNA-dependent RNA polymerase (NIb) and the coat protein (CP) cistrons, produced recombinant clone TEVRos1(NIb/CP) (Fig. 1a). To promote the release of the heterologous protein from the viral polyprotein, in TEV-Ros1(P1/HC-Pro) three codons (coding for SDK) were fused to the N-terminal end of Ros1 to complete a P1 self-proteolytic site and eleven codons 
(coding for TTENLYFQ/SGT) were fused to the C-terminal end of Ros1 to introduce an Nla proteinase (NlaPro) artificial proteolytic site. In TEV-Ros1(NIb/CP) three codons (coding for SGT) and eight codons (coding for TTENLYFQ) were fused respectively to the N- and C-terminal ends of Ros1 to complete NlaPro-specific NIb/Ros1 and Ros1/CP proteolytic sites (Supplemental Fig. 1). These cDNAs were agroinoculated in tobacco plants. New tobacco plants were mechanically inoculated with sap from infected plants in the third true leaf. For both viral recombinant clones, typical TEV symptoms arose in some of the leaves above the inoculated 4 days post inoculation (dpi). Those leaf areas first showing symptoms then turned red with an approximately 1 or 2-day delay (Fig. 1b, pictures corresponding to clone TEV-Ros1(NIb/CP)). Fig. 1c shows a similar time series but focusing in a single leaf, the third above the inoculated one, which showed more severe symptoms during infection. For both recombinant viruses, the pattern of red colored anthocyanins matched exactly the pattern of TEV symptoms. Notably, symptoms and anthocyanin accumulation started in the second leaf above the inoculated, skipping one leaf, and expanded intensively into the fourth. Further leaves showed less severe symptoms and spotty anthocyanin accumulation (Fig. 1b).

To further investigate if those tissues showing anthocyanin accumulation are also those supporting virus replication, we constructed an additional recombinant TEV cDNA including two marker cistrons: GFP was inserted between P1 and HC-Pro and Ros1 between NIb and CP (Fig. 2a). The N- and C-terminal peptides described above were fused to both markers to assure proper release from the viral polyprotein (Supplemental Fig. 1). The viral cDNA was agroinoculated in tobacco plants and symptomatic leaves were inspected at several dpi. GFP fluorescence was detected in leaves above the agroinoculated one, concurrently to symptoms development. Anthocyanin accumulation was detected in exactly the same tissues with an approximately 2-day delay. Fig. $2 b$ shows a sector of an infected tobacco leave ( $8 \mathrm{dpi})$ with a matching reticulate pattern of green fluorescence and visible red color. This demonstrates that the tissues in which the red-colored anthocyanins are visually detected are those in which viral genome is being expressed. The delay observed between the fluorescent detection of GFP and the visual detection of anthocyanins suggests that Ros1 needs some time to exert its regulatory action, which nevertheless culminates with pigment accumulation reaching levels sufficient for simple visual detection. 
(a)

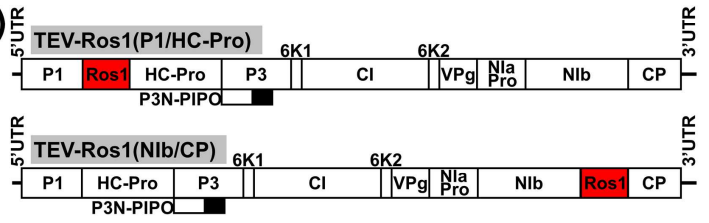

(c)

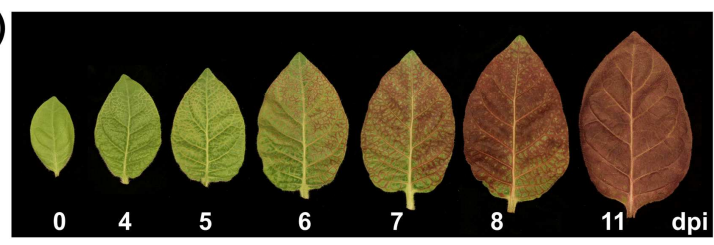

(b)

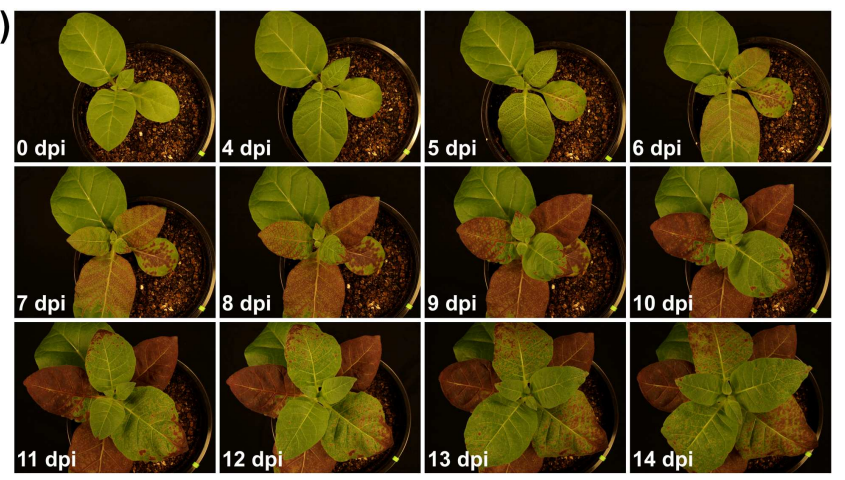

Figure 1. Anthocyanin accumulation in tobacco plants infected by recombinant TEV clones that include the transcription factor Ros1 as a vital visual marker. (a) Schematic representation of recombinant clones TEV-Ros1(P1/HC-Pro) and TEV-Ros1(NIb/CP). TEV 5' and 3' UTRs are indicated by lines, TEV cistrons P1, HC-Pro, P3, P3N-PIPO, 6K1, Cl, 6K2, VPg, NlaPro, NIb and $\mathrm{CP}$ by boxes and Ros 1 cistron by a red box. (b) Pictures at various dpi of a tobacco plant inoculated with TEV-Ros1(NIb/CP). (c) Pictures at various dpi of the third leaf above the inoculated one from tobacco plants infected with TEV-Ros1(NIb/CP).

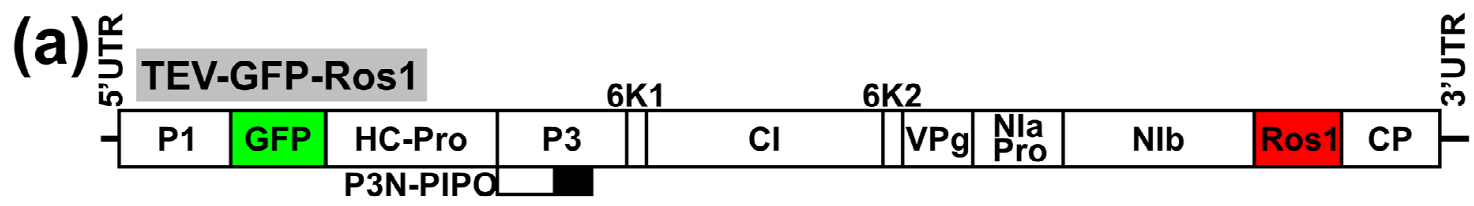

(b)
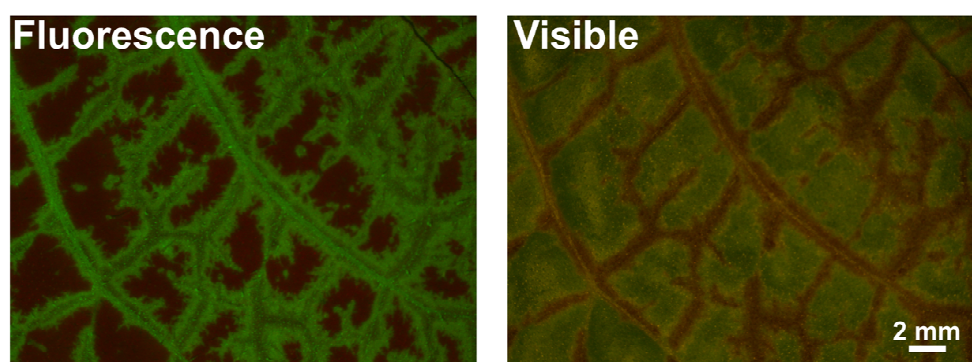

Figure 2. Green fluorescence and anthocyanin accumulation in a tobacco leaf infected by a recombinant TEV clone that includes GFP and Ros1 reporter markers. (a) Schematic representation of the recombinant clone TEV-GFP-Ros1. GFP and Ros1 cistrons are represented by green and red boxes, respectively. Other details are as in Figure 1a. (b) Stereomicroscope pictures of an infected tobacco leave under green fluorescence and visible conditions. Scale bars represent $2 \mathrm{~mm}$.

To confirm the apparent correlation between virus replication and pigment accumulation, we infected tobacco plants with TEV-Ros1(NIb/CP) and harvested the second leaf above the inoculated at $9 \mathrm{dpi}$. This leaf typically develops symptoms only in the basal part. Tissue was sampled and RNA purified from the green and red parts of the leaf, as well as in the border between both regions (Fig. 3a). In the analysis, a control from a non-inoculated plant was also included. Next, the presence of TEV was detected by RT-PCR. A 790-bp TEV-specific DNA was exclusively amplified from the tissues in the red and green-red border part of the leaf (Fig. 3b, lanes 3 and 4), 
indicating that TEV genome is only substantially present in those tissues which accumulated anthocyanins.

We then asked if the amount of anthocyanin accumulating in infected tissue quantitatively correlated to viral load. To address this question, we recurred to three TEV mutant clones showing defects in viral accumulation compared to wild-type. TEVCLA2, TEV-AS13a and TEV-AS20a contain mutations in the allele corresponding to the viral RNA silencing suppressor HC-Pro. These mutations confer RNA silencing hyposuppressor activity to the corresponding proteins, resulting in lower viral genome amplification capacity during protoplast infection and a lower viral load in infected plants (Kasschau et al., 1997; Torres-Barceló et al., 2008; Torres-Barceló et al., 2010). Note that AS13a and AS20a contain only one of the two mutations present in the previously described hypo-suppressor mutants AS13 and AS20 (Kasschau et al., 1997; TorresBarceló et al., 2008). Mutations were transferred to TEV-Ros1(Nlb/CP) cDNA creating TEV(CLA2)-Ros1(NIb/CP), TEV(AS13a)-Ros1(NIb/CP) and TEV(AS20a)Ros1(NIb/CP). These cDNAs, as well as the corresponding wild-type control TEVRos1(NIb/CP), were agroinoculated in tobacco plants and virions were purified from infected tissue. Virion concentration in each preparation was quantified by western analysis using an anti-CP antibody. Subsequently, tobacco plants were mechanically inoculated with normalized amounts of the different virion preparations. During the following days, red coloration appeared in all infected plants, but those infected with TEV mutants showed lower pigmentation than those infected with the wild-type control. Fig. $4 \mathrm{a}$ depicts the third leaves above those inoculated taken from representative plants at $10 \mathrm{dpi}$. Tissue from these third leaves was harvested from three independent plants infected with each virion preparation, as well as from a non-inoculated control. In those tissues, viral load was quantified by western analysis using the anti-CP antibody. Anthocyanins were also extracted from the same tissues and quantified spectrophotometrically. The plot in Fig. $4 b$ shows a good correlation between anthocyanin accumulation and viral load. These results indicate that Ros1 readily reports on viral load both qualitatively (eye inspection), but also quantitatively through a very simple colorimetric assay of a tissue homogenate. 
(a)

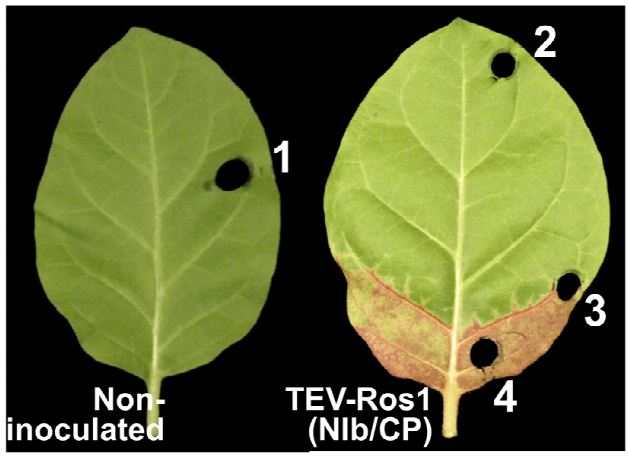

(b)

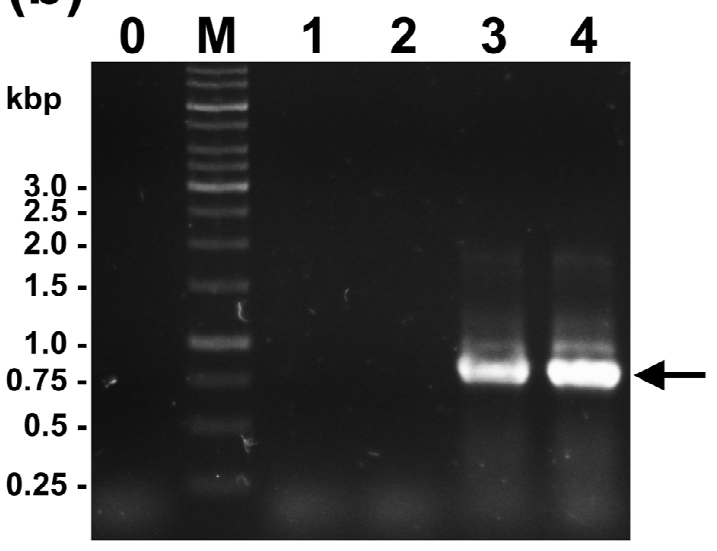

Figure 3. TEV diagnosis in a tobacco leaf infected by TEV-Ros 1 (NIb/CP). (a) RNA was extracted and purified from tissue samples from a tobacco non-inoculated control (1) and from a tobacco leaf infected by TEV-Ros1(NIb/CP) showing green (2), green-red (3) or red (4) pigmentation. (b) TEV was diagnosed by RT-PCR and the amplification products separated by agarose electrophoresis. Lane 0, RT-PCR negative control with no template. Lane M, DNA ladder markers with some sizes indicated on the left. Lanes 1 to 4, RT-PCR products amplified from RNA samples 1 to 4 . The 790-bp TEV-specific DNA amplification product corresponding to $\mathrm{CP}$ cistron is indicated by an arrow.

To perform properly as a reporter of plant virus infection, Ros1 should be maintained in the recombinant virus genome for the whole infectious cycle. To analyze this question, a virus inoculum from an initially agroinoculated tobacco plant was serially propagated from plant to plant each 9 days. Pictures of the successive infected plants were taken just before harvesting the tissue for the subsequent passage (Fig. 5). This experiment spanned a total of six passages (seven infected plants) and demonstrates the high stability of the Ros1 reporter in the TEV genome.

(a)

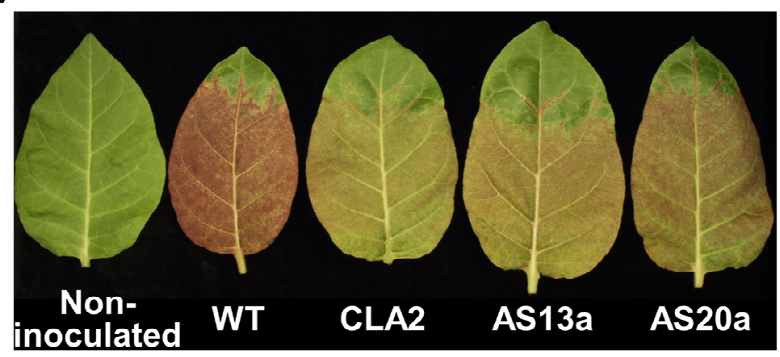

(b)

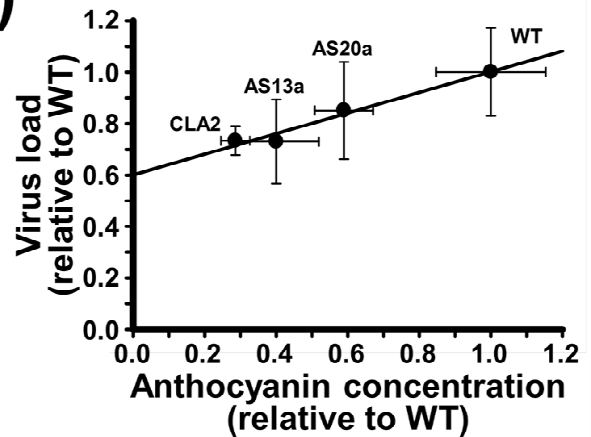

Figure 4. Correlation between anthocyanin accumulation and viral load in tobacco leaves infected by TEV-Ros1(NIb/CP) and the corresponding HC-Pro mutants CLA2, AS13a and AS20a. (a) Pictures of the third leaves above the inoculated from tobacco plants non-inoculated or infected (10 dpi) with TEV-Ros1(Nlb/CP) (WT), TEV(CLA2)-Ros1(Nlb/CP) (CLA2), TEV(AS13a)-Ros1(Nlb/CP) (AS13a) and TEV(AS20a)-Ros1(Nlb/CP) (AS20a). (b) Plot of the anthocyanin accumulation relative to WT virus versus virus load relative to WT virus. Bars 
indicate the standard deviation of each measure on three plant replicates. A linear regression was fitted to the data $(y=0.4 x+0.6, r=0.98)$.

Finally, we tested if the reporter properties shown by Ros 1 in infections of tobacco by TEV can be extended to other viruses belonging to the same or different taxonomic groups, and to different host plant species. Towards this aim, we constructed additional recombinant viral cDNAs including the Ros1 reporter marker. Ros1 was inserted between NIb and $\mathrm{CP}$ in a Turnip mosaic virus (TuMV, genus Potyvirus, family Potyviridae) infectious cDNA (TuMV-Ros1, Fig. 6a). Ros1 included N-terminal and Cterminal peptide fusions to complete TuMV NlaPro cleavage sites NIb/Ros 1 and Ros1/CP (Supplemental Fig. 1). Ros1 was also inserted after a duplicated CP promoter in the cDNAs of Tobacco mosaic virus (TMV, genus Tobamovirus, family Virgaviridae), of Potato virus X (PVX, genus Potexvirus, family Alphaflexiviridae) and of the RNA 2 of Tobacco rattle virus (TRV, genus Tobravirus, family Virgaviridae) to create TMV-Ros1, PVX-Ros1 and TRV2-Ros1, respectively (Fig. 6a). The full sequences of all these virus recombinant cDNAs are in Supplemental Fig. 1.
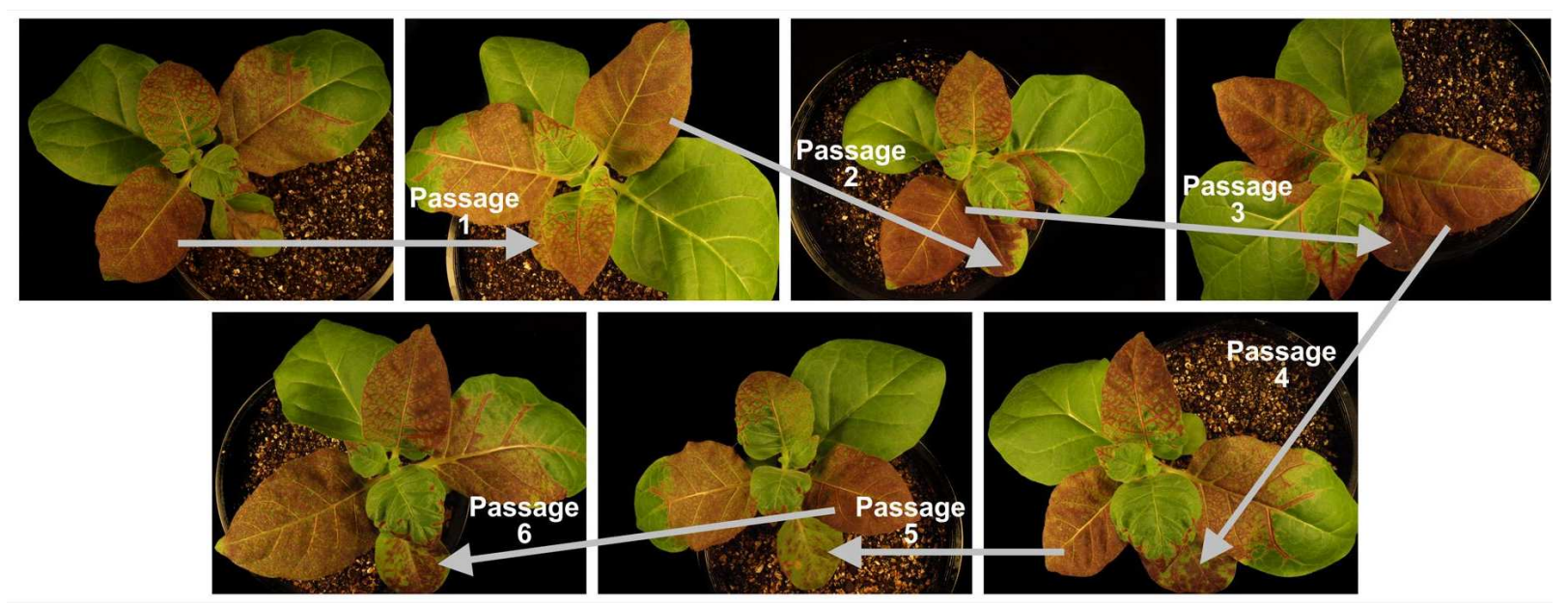

Figure 5. Stability of the Ros1 reporter marker in TEV-Ros1(Nlb/CP) through six infective passages in tobacco plants. The first plant was agroinoculated and the following were successively inoculated with sap from the previous infected plant. Pictures were taken at 9 dpi just before passaging.

Firstly, the model plant Arabidopsis thaliana L. (accession Col-0) was mechanically inoculated with inocula containing either wild-type TuMV or TuMV-Ros1. Inoculated plants developed the symptoms characteristic of TuMV. Again with some delay, symptomatic tissue became purple, indicating anthocyanin accumulation. Fig. 6b shows representative $A$. thaliana plants infected by wild-type TuMV and TuMV-Ros 1 at 20 dpi. The purple color is particularly visible on the reverse side of the leaves. Secondly, 
Nicotiana benthamiana Domin plants, also a model in many studies in plant virology, were inoculated mechanically with inocula corresponding to TEV-Ros1(NIb/CP), TMVRos1, PVX-Ros1 and TRV-Ros1. Inocula originated from previously agroinoculated plants. Between 8 and $13 \mathrm{dpi}$ the different viruses induced their characteristic symptoms. With an approximately 2-day delay, symptomatic tissue become brown in the case of TEV-Ros1(Nlb/CP), TMV-Ros1 and PVX-Ros1 (Fig. 6c). Although TRVRos1 induced symptoms, symptomatic tissue never developed any pigmentation that could be attributed to anthocyanin accumulation.

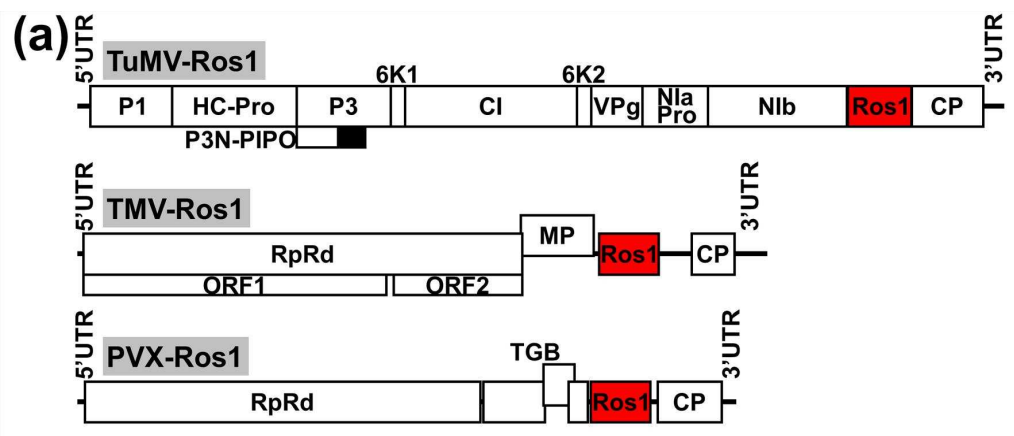

(b)
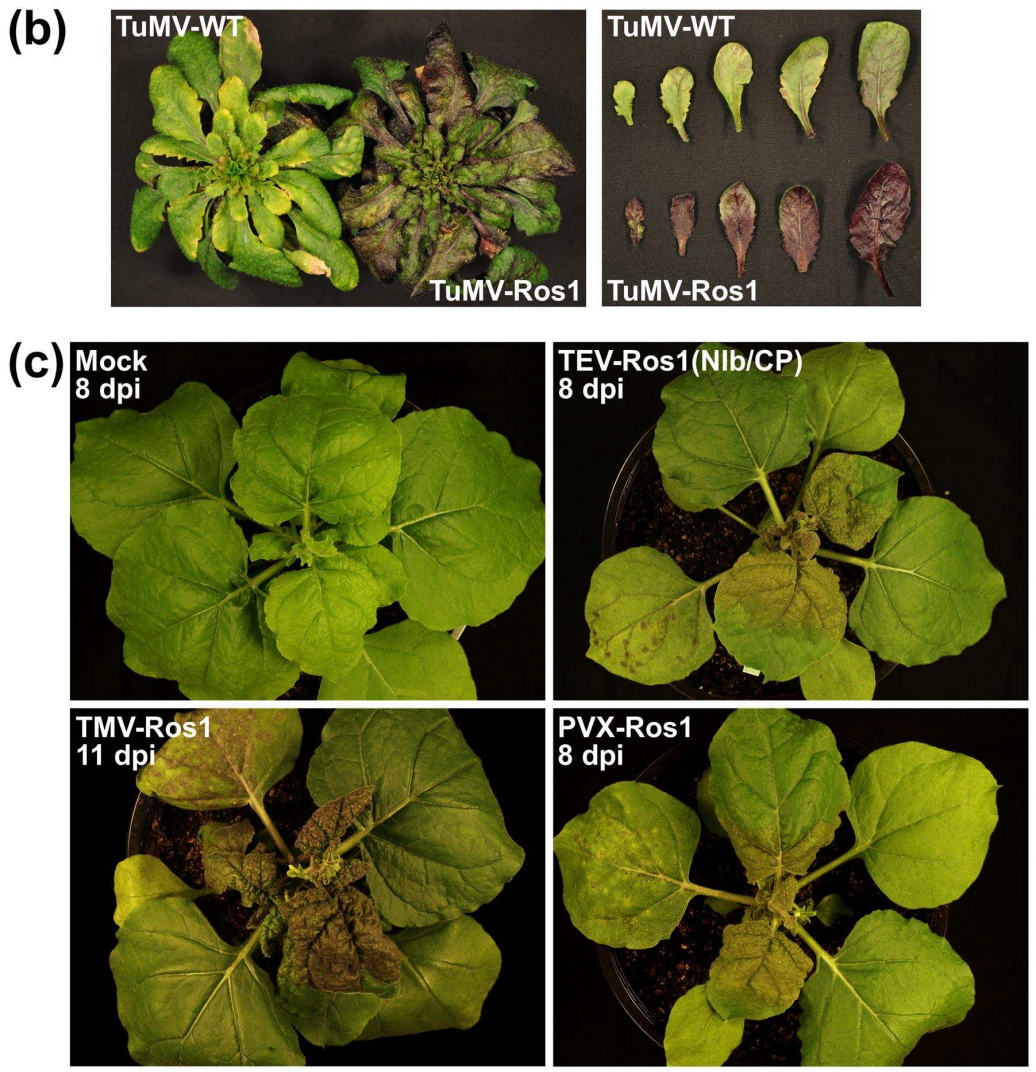

Figure 6. Anthocyanin accumulation in $A$. thaliana and $N$. benthamiana plants infected by recombinant clones of several viruses including the Ros1 reporter marker. (a) Schematic representation of TuMV-Ros1, TMV-Ros1 and PVX-Ros1. Ros1 marker is represented by a red box. RNA-dependent RNA polymerases (RdRp), movement proteins (MP), triple gene block (TGB) are represented by boxes. Other details are as in Figure 1a. (b) Pictures of $A$. thaliana plants infected by TuMV-WT and TuMV-Ros1 (20 dpi). A detail of the reverse side of the leaves is also included. (c) Pictures of $N$. benthamiana plants mock-inoculated and infected by TEVRos1(Nlb/CP), TMV-Ros1 and PVX-Ros1 at different dpi. 


\section{DISCUSSION}

We show here the use of natural plant pigments as a reporter system for visual tracking of plant virus infection dynamics through the plant. The system is based on the expression of the MYB-related $A$. majus transcription factor Ros1 which activates anthocyanin biosynthesis. There are a few examples in the literature in which plant pigments are used as visual reporter systems, most of them consisting of tissue depigmentation. The silencing of phytoene desaturase (PDS), a gene involved in carotenoid biosynthesis, is often used as a marker of virus induced gene silencing (VIGS). The lack of carotenoids destabilizes the chlorophylls yielding a readily visible white phenotype (Liu et al., 2002). Silencing of PDS also served as reporter in carotenoid rich organs as tomato fruits (Fu et al., 2005; Orzaez et al., 2006). Similarly, silencing of chalcone synthase, a key enzyme in anthocyanin biosynthesis, has been used as an endogenous reporter for gene silencing in anthocyanin-rich organs as flower petals (Chen et al., 2004). Silencing of the transgenically-expressed transcription factors Ros1 and Delila was also used as a VIGS reporter in purple tomatoes (Orzaez et al., 2009). In contrast, strategies based on induction of tissue pigmentation are not so common, although recently, anthocyanin accumulation has been proposed as a method for identity preservation in plant biotechnology (Juarez et al., 2009), and as a selection system in plant transformation (Kortstee et al., 2011).

The experiments shown here demonstrate that the A. majus transcription factor Ros 1 may be useful as a reporter gene in the research of many aspects of plant molecular virology and virus-plant interaction for a series of virus-host plant combinations. Ros1 interacts with the companion transcription factor Delila to activate almost all genes encoding anthocyanin biosynthetic enzymes, including genes required for side chain modification and two genes involved in vacuolar import (Schwinn et al., 2006; Butelli et al., 2008). Previously, we showed that the simultaneous expression of both transcription factors Delila and Ros1 through a disarmed TEV-based expression vector induced a dark red coloration in infected tobacco tissues (Bedoya et al., 2010). However, the combined size of Delila and Ros1 cDNAs (2592 bp) precludes the use of both proteins as a reporter marker system. In this work we show that the sole expression of Ros1 is sufficient to induce anthocyanin accumulation to a level clearly visible to the naked eye (Fig. 1). Ros 1 ORF is $660 \mathrm{bp}$ and codes for a $25.7-\mathrm{kDa}$ protein. This size is comparable to those of GFP and related fluorescent proteins. It is, however, significantly larger than the approximately $10-\mathrm{kDa}$ fluorescent reporter iLOV (Chapman et al., 2008). 
Nonetheless, as a clear advantage of Ros1 versus GFP or iLOV, the product of Ros1 activity (anthocyanins) can be easily detected by naked eye. Consequently, many plants could be quickly monitored and screened visually without the need for artificial irradiation, and in a non-destructive manner. This property may be desirable in experimental strategies in which plant viruses are used for large screenings or in which virus properties like infectivity or systemic movement are screened in many virus mutants. The suitability of a reporter system of this kind, based on the production of anthocyanin pigments as a way to non-invasive identification of infected cell was already discussed when Baulcombe et al. (1995) demonstrated the properties of GFP as a reporter for virus infection.

The success of a virus-encoded R2R3 MYB transcription factor at inducing anthocyanin accumulation in the absence of its interaction partners is not entirely surprising. It has been observed before that the MYB component is often the limiting factor in anthocyanin production (Piazza et al., 2002; Schwinn et al., 2006; Albert et al., 2011). The sole overexpression of some R2R3 MYB factors like tomato ANT1 or petunia (Petunia x hybrida hort. Ex E.Vilm.) DPL and PHZ induced red or purple coloration in vegetative tissues (Mathews et al., 2003; Albert et al., 2011). However, the overexpression of the MYB component is not always sufficient. Transient expression of an apple (Malus $x$ domestica Borkh.) MYB factor (MdMYB10) induced only a weak anthocyanin response in $N$. benthamiana and required the presence of a recombinant bHLH partner to fully activate the target promoters (Espley et al., 2007; Lin-Wang et al., 2010). In our case, the expression levels conferred by the different viruses or the concomitant expression of the corresponding viral RNA silencing suppressors may explain the ability of Ros 1 to activate pigmentation on its own in most instances. Moreover, its endogenous interaction partners could themselves be activated by the stress imposed by the virus infection, resulting in an enhanced anthocyanin response. Indeed, it is known that viral infection can activate anthocyanin biosynthesis (Gutha et al., 2010), and therefore, we cannot discard that the suitability of Ros1 as a minimal reporter for viral infection in different host species is partially the consequence of the activation of its endogenous interaction partners as a result of the infection. In this sense, the complementation in trans with additional factors, like Delila (introduced as a stable transgene), could be used in the future as a way to modulate the output signal. More elaborated strategies may include the expression of engineered targets of the 
transcription factor coding for different anthocyanin biosynthetic enzymes as a way to modulate color outputs.

In the potyviruses TEV and TuMV, Ros1 is expressed as part of the viral polyprotein which is subsequently processed by the viral encoded proteases. Once released from the viral polyprotein, Ros1 must move to the nucleus to induce anthocyanin biosynthesis. The need for nuclear traffic imposes a limitation to this marker when compared with others like GFP or iLOV, whose intrinsic fluorescence is directly detected. While GFP and iLOV can be used as reporters either as free proteins or when fused to viral proteins, translational fusion of Ros1 to a viral protein may interfere with its regulatory activity. However, the Ros1-based reporter system relying on enzymatic synthesis of pigments may offer increased sensitivity with respect to fluorescent protein markers, similarly to the GUS system, but without the major drawback of destructive sampling.

Our experiments also demonstrated an exquisite co-localization between pigment accumulation and the presence of the Ros1-tagged TEV. This is deduced from the matching patterns of green fluorescence and red pigmentation in tobacco leaves infected by the doubly tagged TEV-GFP-Ros1 (Fig. 2), and from the amplification by RT-PCR of a specific TEV cDNA exclusively from those parts of an infected leaf showing the red pigmentation (Fig. 3). These results suggest that the anthocyanin biosynthetic induction triggered by Ros 1 expression is cell autonomous and does not extend to neighboring tissues or even to the whole plant. This property enables the use of Ros1 to track the virus movement through the plant, to study which tissues are invaded by the virus which are not, and to accurately dissect viral and host factors involved in virus cell-to-cell and systemic movement.

In fact, direct observation of tobacco plants infected by TEV-Ros1(NIb/CP) suggests that, when inoculated in the third true leaf, virus skips the next leaf, colonizes the basal half of the subsequent one, colonizes completely the third and fourth leaves above the inoculated, and only patches of more distal leaves (Fig. 1b). At the end, there are new leaves growing that are apparently free of virus. This observation is coherent with a burst of virus replication and movement during the first days after infection that is finally controlled or ameliorated by the plant antiviral defenses. Nonetheless, we cannot discard the potential presence of minimal amounts of TEV particles in non-red tissues either not expressing the viral genome or expressing it in an amount insufficient to trigger visible anthocyanin accumulation. 
In addition, our experiments also show that Ros1 is a quantitative reporter because anthocyanin accumulation correlates viral load (Fig. 4). Precise quantification can be performed by a very cheap and simple extraction process with acidified methanol followed by a colorimetric measurement (see below Experimental Procedures). In any case, visual inspection of infected tissues gives a qualitative idea of virus accumulation that can be sufficient for many purposes (Fig. 4a). Also very important is the high stability of Ros1 in the genome of the recombinant TEV during the infectious cycle and through successive passages from plant to plant (Fig. 5). Nonetheless, this property is expected to depend on the particular virus species, since some viruses accept insertions better than others. Also, stability will depend on the particular constructive details of each recombinant virus cDNA clone. In our TEV constructs, attention has been paid to avoid long sequence repetitions when inserting the Ros1 marker to avoid undesired homologous recombination (Supplemental Fig. 1).

Finally, our experiments also demonstrate that the properties of Ros1 as a reporter marker can be extended to other viruses belonging to different taxonomic groups and other host plants (Fig. 6). However, this property is not universal, as exemplified by the case of TRV-Ros1 infecting $N$. benthamiana. Since Ros1 needs to move to the nucleus to act and since each particular plant species or plant taxonomic group has a particular anthocyanin biosynthethic pathway, it is expected that the performance of Ros 1 as a reporter marker will depend on each particular virus-host combination. In our work, best results were obtained with TEV infecting tobacco plants, in which Ros1 produces an intense bright red pigmentation (Fig. 1). Good results were also obtained with TuMV infecting $A$. thaliana plants. In this case, the purple pigmentation was particularly bright on the reverse side of the leaves (Fig. 6b). Finally, $N$. benthamiana developed a less bright although clearly visible brown coloration with TEV, TMV and PVX (Fig. 6c). These differences in accumulation and color may reflect the complex interaction of Ros 1 with its endogenous partners, giving rise to the transcriptional activation of different enzymes in different plant species. Additionally, phenotypic differences between species may also be due to the different redox status of the vacuolar milieu. But in conclusion, despite these drawbacks, Ros1 promises to be a useful vital visual marker to track virus infection and movement, and to easily quantify viral load for many virus-plant host combinations. 


\section{MATERIALS AND METHODS}

\section{Plasmids}

Virus clones TEV-Ros1(P1/HC-Pro), TEV-Ros1(Nlb/CP), TEV-GFP-Ros1, TuMV-WT, TuMV-Ros1, TMV-Ros1 and PVX-Ros1 were produced from plasmids pTEVRos1(P1/HC-Pro), pTEV-Ros1(NIb/CP), pTEV-GFP-Ros1, pTuMV, pTuMV-Ros1, pTMV-Ros1 and pPVX-Ros1, respectively. Virus clone TRV-Ros1 was produced from plasmids pTRV1 (Liu et al., 2002) and pTRV2-Ros1. Plasmid pGTEVa derives from pGTEV (Bedoya and Daròs, 2010), contains the TEV cDNA corresponding to Genbank accession number DQ986288 under the control of Cauliflower mosaic virus (CaMV) 35S promoter and terminator, but includes two silent mutations (G273A and A1119G) to remove internal Bsal restriction sites. In pGTEV-Ros1(P1/HC-Pro), pGTEVRos1(NIb/CP) and pGTEV-GFP-Ros1, the Ros1 (DQ275529) and the enhanced GFP (AAB08060) cDNAs were inserted in different positions of pGTEVa by standard techniques based on the use of the type Ils restriction enzyme Bsal (New England Biolabs) and T4 DNA ligase (Fermentas) (Engler et al., 2009). The complete sequences of the resulting viral cDNAs contained in those plasmids are in Supplemental Fig. 1. pGTEV(CLA2)-Ros1(NIb/CP), pGTEV(AS13a)-Ros1(NIb/CP) and pGTEV(AS20a)Ros1(NIb/CP) were like pGTEV-Ros1(NIb/CP) but included the mutations T1631C (CLA2), A1952C (AS13a) or A2135C (AS20a) in the TEV CDNA (HC-Pro cistron). pTuMV-Ros1 is like pTuMV-GFP (Martínez et al., 2011) but replacing the GFP between NIb and CP by Ros1 (Supplemental Fig. 1). In pTMV-Ros1, Ros1 cDNA replaces dsRed of pTMV-dsRed (Canto and Palukaitis, 2002). In pPVX-Ros1, Ros1 cDNA is inserted after the duplicated CP promoter of pgR107 (Lu et al., 2003). In pTRV2-Ros1, Ros1 cDNA is inserted after the duplicated CP promoter of pTRV2 (AF406991) (Liu et al., 2002). The full sequences of the viral cDNAs in all these plasmids are in Supplemental Fig. 1.

\section{$\underline{\text { Plant inoculation }}$}

For agroinoculation of TEV-Ros1(P1/HC-Pro), TEV-Ros1(NIb/CP), TEV-GFP-Ros1 and PVX-Ros1, Agrobacterium tumefaciens C58C1 containing the helper plasmid pCLEANS48 (Thole et al., 2007) was transformed with the corresponding plasmids (see above). Bacteria were grown in liquid culture, adjusted at 0.5 OD $(600 \mathrm{~nm})$ in induction buffer 
(10 mM MES-NaOH, pH 5.6, $10 \mathrm{mM} \mathrm{MgCl}_{2}, 150 \mu \mathrm{M}$ acetosyringone), cultured for $2 \mathrm{~h}$ at $28{ }^{\circ} \mathrm{C}$ and infiltrated in a plant leaf (Bedoya and Daròs, 2010). For agroinoculation of TRV-Ros1, two cultures of $A$. tumefaciens C58C1 each transformed with pTRV1 or pTRV2-Ros1 were treated as above, mixed and infiltrated. TUMV-WT and TuMV-Ros1 were mechanically inoculated from plasmids pTuMV (Martínez et al., 2011) and pTuMVRos1. Finally, TMV-Ros1 was mechanically inoculated from 5'-capped RNA transcripts obtained by in vitro transcription (Bedoya and Daròs, 2010) with T7 RNA polymerase (Epicentre) of plasmid pTMV-Ros1 digested by Kpnl (Fermentas).

Plants were also mechanically inoculated with sap from a previously infected plant. Approximately $100 \mathrm{mg}$ of frozen tissue was homogenized in 20 volumes of $\mathrm{TI}(50 \mathrm{mM}$ potassium phosphate, $\mathrm{pH} 8.0,1 \%$ polyvinylpyrrolidone $10,1 \%$ polyethylene glycol 6000 , $10 \mathrm{mM}$ 2-mercaptoethanol). A cotton swab was soaked in the plant homogenate and gently rubbed on a leaf in which two 10- $\mu$ l drops (one per leaf side) of $10 \%$ Carborundum in TI was previously deposited (Bedoya et al., 2010).

$N$. tabacum and $N$. benthamiana plants were grown in a greenhouse at $25 \stackrel{\circ}{\mathrm{C}}$ with a 16 $\mathrm{h}$ day, $8 \mathrm{~h}$ night cycle. When inoculated, plants were transferred to a growth chamber with a $12 \mathrm{~h}$ day $25^{\circ} \mathrm{C}$ and 12 night $23^{\circ} \mathrm{C}$ cycle. A. thaliana plants were grown all the time in these last conditions.

\section{$\underline{\text { TEV diagnosis by RT-PCR }}$}

RNA was purified from frozen tissue using silica gel columns and eluted in $10 \mu$ l (Zymo Research). One $\mu$ RNA was subjected to reverse transcription with M-MuLV reverse transcriptase (Fermentas) using primer I (5'-CTCGCACTACATAGGAGAATTAGAC-3') in $10 \mu \mathrm{l}$ and $1 \mu \mathrm{l}$ of this reaction to PCR amplification with Thermus thermophilus DNA polymerase (Biotools) with primers II (5'-AGTGGCACTGTGGGTGCTGGTGTTG-3') and III (5'-CTGGCGGACCCCTAATAG-3') in a 20- $\mu$ l reaction. Reaction conditions were as previously described (Bedoya et al., 2010). PCR products were analyzed by electrophoresis in 1\% agarose gels in TAE buffer $(40 \mathrm{mM}$ Tris, $20 \mathrm{mM}$ sodium acetate, $1 \mathrm{mM}$ EDTA, pH 7.2) and staining with ethidium bromide. 
$\underline{\text { Western analysis }}$

Frozen tissue (around $120 \mathrm{mg}$ ) was homogenized in 3 volumes of TEW $(60 \mathrm{mM}$ Tris$\mathrm{HCl}, \mathrm{pH} 6.8,2 \%$ sodium dodecyl sulfate -SDS-, $100 \mathrm{mM}$ dithiothreitol, $10 \%$ glycerol, $0.01 \%$ bromophenol blue). The extract was heated for $5 \mathrm{~min}$ at $98{ }^{\circ} \mathrm{C}$, vortexed and clarified by centrifugation. Supernatants $(5 \mu \mathrm{l})$ were separated by discontinuous polyacrylamide gel electrophoresis in the presence of SDS (SDS-PAGE) in $12.5 \%$ polyacrylamide (resolving gel). Proteins were electroblotted to a PVDF membrane (GE Healthcare) and TEV CP detected through an overnight incubation at room temperature with a 1:10 000 dilution of an anti-CP polyclonal antibody conjugated to alkaline phosphatase (Agdia) (Bedoya et al., 2010). Alkaline phosphatase was detected using a chemiluminescent substrate (CSPD, Roche) and quantified with a luminescent image analyzer (LAS-3000, Fujifilm).

\section{Anthocyanin quantification}

Frozen tobacco tissue (around $150 \mathrm{mg}$ ) was homogenized in 50 volumes of extraction solution $(0.037 \% \mathrm{HCl}$ in methanol). The extract was vortexed vigorously, incubated for 1 $\mathrm{h}$ on ice and clarified by centrifugation for $5 \mathrm{~min}$ at $13,000 \times \mathrm{g}$. Anthocyanin concentration was measured in the supernatant quantifying absorbance at $530 \mathrm{~nm}$ and subtracting the absorbance of a similar extract from a non-inoculated plant.

\section{ACKNOWLEDGEMENTS}

We thank Verónica Aragonés for excellent technical assistance and Dr. C. Douglas Grubb (Leibniz-Institut für Pflanzenbiochemie, Germany) for critical review of the manuscript.

\section{REFERENCES}

Albert NW, Lewis DH, Zhang H, Schwinn KE, Jameson PE, Davies KM (2011) Members of an R2R3-MYB transcription factor family in Petunia are developmentally and environmentally regulated to control complex floral and vegetative pigmentation patterning. Plant J 65: 771-784 
Baulcombe DC, Chapman S, Santa Cruz S (1995) Jellyfish green fluorescent protein as a reporter for virus infections. Plant J 7: 1045-1053

Beauchemin C, Bougie V, Laliberté JF (2005) Simultaneous production of two foreign proteins from a polyvirus-based vector. Virus Res 112: 1-8

Bedoya L, Martínez F, Rubio L, Daròs JA (2010) Simultaneous equimolar expression of multiple proteins in plants from a disarmed potyvirus vector. J Biotechnol 150: 268-275

Bedoya LC, Daròs JA (2010) Stability of Tobacco etch virus infectious clones in plasmid vectors. Virus Res 149: 234-240

Butelli E, Titta L, Giorgio M, Mock HP, Matros A, Peterek S, Schijlen EG, Hall RD, Bovy AG, Luo J, Martin C (2008) Enrichment of tomato fruit with health-promoting anthocyanins by expression of select transcription factors. Nat Biotechnol 26: $1301-$ 1308

Canto T, Palukaitis P (2002) Novel N gene-associated, temperature-independent resistance to the movement of tobacco mosaic virus vectors neutralized by a cucumber mosaic virus RNA1 transgene. J Virol 76: 12908-12916

Caplan JL, Mamillapalli P, Burch-Smith TM, Czymmek K, Dinesh-Kumar SP (2008) Chloroplastic protein NRIP1 mediates innate immune receptor recognition of a viral effector. Cell 132: 449-462

Citovsky V, Lee LY, Vyas S, Glick E, Chen MH, Vainstein A, Gafni Y, Gelvin SB, Tzfira T (2006) Subcellular localization of interacting proteins by bimolecular fluorescence complementation in planta. J Mol Biol 362: 1120-1131

Chalker-Scott L (1999) Environmental significance of anthocyanins in plant stress responses. Photochem Photobiol 70: 1-9

Chapman S, Faulkner C, Kaiserli E, Garcia-Mata C, Savenkov El, Roberts AG, Oparka KJ, Christie JM (2008) The photoreversible fluorescent protein iLOV outperforms GFP as a reporter of plant virus infection. Proc Natl Acad Sci USA 105: 20038-20043

Chapman S, Kavanagh T, Baulcombe D (1992) Potato virus X as a vector for gene expression in plants. Plant J 2: 549-557

Chen JC, Jiang CZ, Gookin TE, Hunter DA, Clark DG, Reid MS (2004) Chalcone synthase as a reporter in virus-induced gene silencing studies of flower senescence. Plant Mol Biol 55: 521-530 
Day RN, Davidson MW (2009) The fluorescent protein palette: tools for cellular imaging. Chem Soc Rev 38: 2887-2921

Dolja VV, McBride HJ, Carrington JC (1992) Tagging of plant potyvirus replication and movement by insertion of b-glucuronidase into the viral polyprotein. Proc Natl Acad Sci USA 89: 10208-10212

Engler C, Gruetzner R, Kandzia R, Marillonnet S (2009) Golden gate shuffling: a onepot DNA shuffling method based on type Ils restriction enzymes. PLoS One 4: e5553

Espley RV, Hellens RP, Putterill J, Stevenson DE, Kutty-Amma S, Allan AC (2007) Red colouration in apple fruit is due to the activity of the MYB transcription factor, MdMYB10. Plant J 49: 414-427

Fu DQ, Zhu BZ, Zhu HL, Jiang WB, Luo YB (2005) Virus-induced gene silencing in tomato fruit. Plant J 43: 299-308

Gutha LR, Casassa LF, Harbertson JF, Naidu RA (2010) Modulation of flavonoid biosynthetic pathway genes and anthocyanins due to virus infection in grapevine (Vitis vinifera L.) leaves. BMC Plant Biol 10: 187

He Q, Shen Y, Wang M, Huang M, Yang R, Zhu S, Wang L, Xu Y, Wu R (2011) Natural variation in petal color in Lycoris longituba revealed by anthocyanin components. PLoS One 6: e22098

Hichri I, Barrieu F, Bogs J, Kappel C, Delrot S, Lauvergeat V (2011) Recent advances in the transcriptional regulation of the flavonoid biosynthetic pathway. $J$ Exp Bot 62: 2465-2483

Juarez P, Timoner F, Presa S, Granell A, Orzáez D (2009) Tomato-made recombinant human IgA against rotavirus. New Biotechnol 25: S288-S288

Kasschau KD, Cronin S, Carrington JC (1997) Genome amplification and longdistance movement functions associated with the central domain of tobacco etch potyvirus helper component-proteinase. Virology 228: 251-262

Kelloniemi J, Mäkinen K, Valkonen JP (2008) Three heterologous proteins simultaneously expressed from a chimeric potyvirus: infectivity, stability and the correlation of genome and virion lengths. Virus Res 135: 282-291

Kortstee AJ, Khan SA, Helderman C, Trindade LM, Wu Y, Visser RG, Brendolise C, Allan A, Schouten HJ, Jacobsen E (2011) Anthocyanin production as a potential visual selection marker during plant transformation. Transgenic Res 
Lalonde S, Ehrhardt DW, Loqué D, Chen J, Rhee SY, Frommer WB (2008) Molecular and cellular approaches for the detection of protein-protein interactions: latest techniques and current limitations. Plant J 53: 610-635

Lin-Wang K, Bolitho K, Grafton K, Kortstee A, Karunairetnam S, McGhie TK, Espley RV, Hellens RP, Allan AC (2010) An R2R3 MYB transcription factor associated with regulation of the anthocyanin biosynthetic pathway in Rosaceae. BMC Plant Biol 10: 50

Liu Y, Schiff M, Dinesh-Kumar SP (2002) Virus-induced gene silencing in tomato. Plant J 31: 777-786

Lu R, Malcuit I, Moffett P, Ruiz MT, Peart J, Wu AJ, Rathjen JP, Bendahmane A, Day L, Baulcombe DC (2003) High throughput virus-induced gene silencing implicates heat shock protein 90 in plant disease resistance. EMBO J 22: 56905699

Luo J, Butelli E, Hill L, Parr A, Niggeweg R, Bailey P, Weisshaar B, Martin C (2008) AtMYB12 regulates caffeoyl quinic acid and flavonol synthesis in tomato: expression in fruit results in very high levels of both types of polyphenol. Plant $\mathrm{J}$ 56: 316-326

Martin K, Kopperud K, Chakrabarty R, Banerjee R, Brooks R, Goodin MM (2009) Transient expression in Nicotiana benthamiana fluorescent marker lines provides enhanced definition of protein localization, movement and interactions in planta. Plant J 59: 150-162

Martínez F, Sardanyés J, Elena SF, Daròs JA (2011) Dynamics of a plant RNA virus intracellular accumulation: stamping machine vs. geometric replication. Genetics 188: $637-646$

Mathews H, Clendennen SK, Caldwell CG, Liu XL, Connors K, Matheis N, Schuster DK, Menasco DJ, Wagoner W, Lightner J, Wagner DR (2003) Activation tagging in tomato identifies a transcriptional regulator of anthocyanin biosynthesis, modification, and transport. Plant Cell 15: 1689-1703

Orzaez D, Medina A, Torre S, Fernández-Moreno JP, Rambla JL, Fernández-delCarmen A, Butelli E, Martin C, Granell A (2009) A visual reporter system for virusinduced gene silencing in tomato fruit based on anthocyanin accumulation. Plant Physiol 150: 1122-1134 
Orzaez D, Mirabel S, Wieland WH, Granell A (2006) Agroinjection of tomato fruits. A tool for rapid functional analysis of transgenes directly in fruit. Plant Physiol 140: 311

Ougham HJ, Morris P, Thomas H (2005) The colors of autumn leaves as symptoms of cellular recycling and defenses against environmental stresses. In Curr Top Dev Biol (Gerald, PS ed) Academic Press, pp 135-160

Piazza P, Procissi A, Jenkins GI, Tonelli C (2002) Members of the c1/pl1 regulatory gene family mediate the response of maize aleurone and mesocotyl to different light qualities and cytokinins. Plant Physiol 128: 1077-1086

Piston DW, Kremers GJ (2007) Fluorescent protein FRET: the good, the bad and the ugly. Trends Biochem Sci 32: 407-414

Scholthof HB, Morris TJ, Jackson AO (1993) The capsid protein gne of tomato bushy stunt virus is dispensable for systemic movement and can be replaced for localized expression of foreign genes. Mol Plant-Microbe Interact 6: 309-322

Schwinn K, Venail J, Shang Y, Mackay S, Alm V, Butelli E, Oyama R, Bailey P, Davies K, Martin C (2006) A small family of MYB-regulatory genes controls floral pigmentation intensity and patterning in the genus Antirrhinum. Plant Cell 18: 831851

Thole V, Worland B, Snape JW, Vain P (2007) The pCLEAN dual binary vector system for Agrobacterium-mediated plant transformation. Plant Physiol 145: 12111219

Tilsner J, Oparka KJ (2010) Tracking the green invaders: advances in imaging virus infection in plants. Biochem J 430: 21-37

Torres-Barceló C, Daròs JA, Elena SF (2010) Compensatory molecular evolution of HC-Pro, an RNA-silencing suppressor from a plant RNA virus. Mol Biol Evol 27: 543-551

Torres-Barceló C, Martín S, Daròs JA, Elena SF (2008) From hypo- to hypersuppression: effect of amino acid substitutions on the RNA-silencing suppressor activity of the Tobacco etch potyvirus HC-Pro. Genetics 180: 1039-1049

Ververidis F, Trantas E, Douglas C, Vollmer G, Kretzschmar G, Panopoulos N (2007) Biotechnology of flavonoids and other phenylpropanoid-derived natural products. Part II: reconstruction of multienzyme pathways in plants and microbes. Biotechnol J 2: 1235-1249 
Wei T, Huang TS, McNeil J, Laliberté JF, Hong J, Nelson RS, Wang A (2010) Sequential recruitment of the endoplasmic reticulum and chloroplasts for plant potyvirus replication. J Virol 84: 799-809

Wei T, Zhang C, Hong J, Xiong R, Kasschau KD, Zhou X, Carrington JC, Wang A (2010) Formation of complexes at plasmodesmata for potyvirus intercellular movement is mediated by the viral protein P3N-PIPO. PLoS Pathog 6: e1000962

Winefield C, Davies K, Gould K (2009) Anthocyanins. New York: Springer 
SUPPLEMENTARY MATERIAL

Supplementary Figure 1. Full sequence of the recombinant viral clones TEV-Ros1(P1/HC-
Pro), TEV-Ros1(NIb/CP), TEV-GFP-Ros1, TuMV-Ros1, TMV-Ros1, PVX-Ros1 and TRV2-
Ros1. In all cases the cDNA sequence corresponding to Ros 1 is highlighted on red background.

$>$ TEV-Ros1(P1/HC-Pro)

GAAAATAACAAATCTCAACACAACATATACAAAACAAACGAATCTCAAGCAATCAAGCATTCTACTTCTATTGCAGCAATTTAAATCATTTCTTTTA AAGCAAAAGCAATTTTCTGAAAATTTTCACCATTTACGAACGATAGCCATGGCACTCATCTTTGGCACAGTCAACGCTAACATCCTGAAGGAAGTGT TCGGTGGAGCTCGTATGGCTTGCGTTACCAGCGCACATATGGCTGGAGCGAATGGAAGCATTTTGAAGAAGGCAGAAGAAACCTCTCGTGCAATCAT GCACAAACCAGTGATCTTCGGAGAAGACTACATTACCGAGGCAGACTTGCCTTACACACCACTCCATTTAGAGGTCGATGCTGAAATGGAGCGGATG TATTATCTTGGTCGTCGCGCGCTCACCCATGGCAAGAGACGCAAAGTTTCTGTGAATAACAAGAGGAACAGGAGAAGGAAAGTGGCCAAAACGTACG TGGGGCGTGATTCCATTGTTGAGAAGATTGTAGTGCCCCACACCGAGAGAAAGGTTGATACCACAGCAGCAGTGGAAGACATTTGCAATGAAGCTAC CACTCAACTTGTGCATAATAGTATGCCAAAGCGTAAGAAGCAGAAAAACTTCTTGCCCGCCACTTCACTAAGTAACGTGTATGCCCAAACTTGGAGC ATAGTGCGCAAACGCCATATGCAGGTGGAGATCATTAGCAAGAAGAGCGTCCGAGCGAGGGTCAAGAGATTTGAGGGCTCGGTGCAATTGTTCGCAA GTGTGCGTCACATGTATGGCGAGAGGAAAAGGGTGGACTTACGTATTGACAACTGGCAGCAAGAGACACTTCTAGACCTTGCTAAAAGATTTAAGAA TGAGAGAGTGGATCAATCGAAGCTCACTTTTGGTTCAAGTGGCCTAGTTTTGAGGCAAGGCTCGTACGGACCTGCGCATTGGTATCGACATGGTATG TTCATTGTACGCGGTCGGTCGGATGGGATGTTGGTGGATGCTCGTGCGAAGGTAACGTTCGCTGTTTGTCACTCAATGACACATTATAGCGACAAAA TGGAAAAGAATTGTCGTGGAGTGAGAAAAGGTACTTGGACCAAAGAAGAAGACACTCTCTTGAGGCAATGTATAGAAGAGTATGGTGAAGGGAAATE GCATCAAGTTCCACACAGAGCAGGGTTGAACCGGTGTAGGAAGAGTTGCAGGCTGAGGTGGTTGAATTATCTGAGGCCAAATATCAAAAGAGGTCGE TTTTCGAGAGATGAAGTGGACCTAATTGTGAGGCTTCATAAGCTGTTGGGTAACAAATGGTCGCTGATTGCTGGTAGAATTCCTGGAAGGACAGCTA ATGACGTGAAGAАCTTTTGAATACTCATGTGGGGAAGAATTTAGGCGAGGATGGAGAACGATGCCGGAAAAATGTTATGAACACAAAAACCATTAA GCTGACTAATATCGTAAGACCCCGAGCTCGGACCTTCACCGGATTGCACGTTACTTGGCCGAGAGAAGTCGGAAAAACCGATGAATTTTCAAATGTC CGGTTAACAACTGATGAGATTCCAGATTGTGAGAAGCAAACGCAATTTTACAATGATGTTGCGTCGCCACAAGATGAAGTTGAAGACTGCATTCAGT

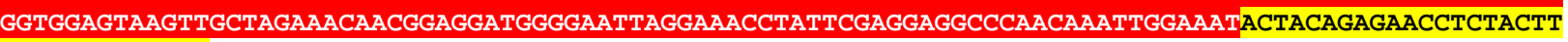
TCAATCAGGTACAAGCGACAAATCAATCTCTGAGGCATTCTTCATACCATACTCTAAGAAATTCTTGGAGTTGAGGCCAGATGGAATCTCCCATGAG TGTACAAGAGGAGTATCAGTTGAGCGGTGCGGTGAGGTGGCTGCAATCCTGACACAAGCACTTTCACCGTGTGGTAAGATCACATGCAAACGTTGCA TGGTTGAAACACCTGACATTGTTGAGGGTGAGTCGGGAGACAGTGTCACCAACCAAGGTAAGCTCCTAGCAATGCTGAAAGAACAGTATCCAGATTT CCCAATGGCCGAGAAACTACTCACAAGGTTTTTGCAACAGAAATCACTAGTAAATACAAATTTGACAGCCTGCGTGAGCGTCAAACAACTCATTGGT GACCGCAAACAAGCTCCATTCACACACGTACTGGCTGTCAGCGAAATTCTGTTTAAAGGCAATAAACTAACAGGGGCCGATCTCGAAGAGGCAAGCA CACATATGCTTGAAATAGCAAGGTTCTTGAACAATCGCACTGAAAATATGCGCATTGGCCACCTTGGTTCTTTCAGAAATAAAATCTCATCGAAGGC CCATGTGAATAACGCACTCATGTGTGATAATCAACTTGATCAGAATGGGAATTTTATTTGGGGACTAAGGGGTGCACACGCAAAGAGGTTTCTTAAA GGATTTTTCACTGAGATTGACCCAAATGAAGGATACGATAAGTATGTTATCAGGAAACATATCAGGGGTAGCAGAAAGCTAGCAATTGGCAATTTGA TAATGTCAACTGACTTCCAGACGCTCAGGCAACAAATTCAAGGCGAAACTATTGAGCGTAAAGAAATTGGGAATCACTGCATTTCAATGCGGAATGG TAATTACGTGTACCCATGTTGTTGTGTTACTCTTGAAGATGGTAAGGCTCAATATTCGGATCTAAAGCATCCAACGAAGAGACATCTGGTCATTGGC AACTCTGGCGATTCAAAGTACCTAGACCTTCCAGTTCTCAATGAAGAGAAAATGTATATAGCTAATGAAGGTTATTGCTACATGAACATTTTCTTTG CTCTACTAGTGAATGTCAAGGAAGAGGATGCAAAGGACTTCACCAAGTTTATAAGGGACACAATTGTTCCAAAGCTTGGAGCGTGGCCAACAATGCA AGATGTTGCAACTGCATGCTACTTACTTTCCATTCTTTACCCAGATGTCCTGAGTGCTGAATTACCCAGAATTTTGGTTGATCATGACAACAAAACA ATGCATGTTTTGGATTCGTATGGGTCTAGAACGACAGGATACCACATGTTGAAAATGAACACAACATCCCAGCTAATTGAATTCGTTCATTCAGGTT TGGAATCCGAAATGAAAACTTACAATGTTGGAGGGATGAACCGAGATATGGTCACACAAGGTGCAATTGAGATGTTGATCAAGTCCATATACAAACC ACATCTCATGAAGCAGTTACTTGAGGAGGAGCCATACATAATTGTCCTGGCAATAGTCTCCCCTTCAATTTTAATTGCCATGTACAACTCTGGAACT TTTGAGCAGGCGTTACAAATGTGGTTGCCAAATACAATGAGGTTAGCTAACCTCGCTGCCATCTTGTCAGCCTTGGCGCAAAAGTTAACTTTGGCAG ACTTGTTCGTCCAGCAGCGTAATTTGATTAATGAGTATGCGCAGGTAATTTTGGACAATCTGATTGACGGTGTCAGGGTTAACCATTCGCTATCCCT AGCAATGGAAATTGTTACTATTAAGCTGGCCACCCAAGAGATGGACATGGCGTTGAGGGAAGGTGGCTATGCTGTGACCTCTGAAAAGGTGCATGAA ATGTTGGAAAAAAACTATGTAAAGGCTTTGAAGGATGCATGGGACGAATTAACTTGGTTGGAAAAATTCTCCGCAATCAGGCATTCAAGAAAGCTCT TGAAATTTGGGCGAAAGCCTTTAATCATGAAAAACACCGTAGATTGCGGCGGACATATAGACTTGTCTGTGAAATCGCTTTTCAAGTTCCACTTGGA ACTCCTGAAGGGAACCATCTCAAGAGCCGTAAATGGTGGTGCAAGAAAGGTAAGAGTAGCGAAGAATGCCATGACAAAAGGGGTTTTTCTCAAAATC TACAGCATGCTTCCTGACGTCTACAAGTTTATCACAGTCTCGAGTGTCCTTTCCTTGTTGTTGACATTCTTATTTCAAATTGACTGCATGATAAGGG CACACCGAGAGGCGAAGGTTGCTGCACAGTTGCAGAAAGAGAGCGAGTGGGACAATATCATCAATAGAACTTTCCAGTATTCTAAGCTTGAAAATCC TATTGGCTATCGCTCTACAGCGGAGGAAAGACTCCAATCAGAACACCCCGAGGCTTTCGAGTACTACAAGTTTTGCATTGGAAAGGAAGACCTCGTT GAACAGGCAAAACAACCGGAGATAGCATACTTTGAAAAGATTATAGCTTTCATCACACTTGTATTAATGGCTTTTGACGCTGAGCGGAGTGATGGAG TGTTCAAGATACTCAATAAGTTCAAAGGAATACTGAGCTCAACGGAGAGGGAGATCATCTACACGCAGAGTTTGGATGATTACGTTACAACCTTTGA TGACAATATGACAATCAACCTCGAGTTGAATATGGATGAACTCCACAAGACGAGCCTTCCTGGAGTCACTTTTAAGCAATGGTGGAACAACCAAATC AGCCGAGGCAACGTGAAGCCACATTATAGAACTGAGGGGCACTTCATGGAGTTTACCAGAGATACTGCGGCATCGGTTGCCAGCGAGATATCACACT CACCCGCAAGAGATTTTCTTGTGAGAGGTGCTGTTGGATCTGGAAAATCCACAGGACTTCCATACCATTTATCAAAGAGAGGGAGAGTGTTAATGCT TGAGCCTACCAGACCACTCACAGATAACGTGCACAAGCAACTGAGAAGTGAACCATTTAACTGCTTCCCAACTTTGAGGATGAGAGGGAAGTCAACT TTTGGGTCATCACCGATTACAGTCATGACTAGTGGATTCGCTTTACACCATTTTGCACGAAACATAGCTGAGGTAAAAACATACGATTTTGTCATAA TTGATGAATGTCATGTGAATGATGCTTCTGCTATAGCGTTTAGGAATCTACTGTTTGAACATGAATTTGAAGGAAAAGTCCTCAAAGTGTCAGCCAC ACCACCAGGTAGAGAAGTTGAATTCACAACTCAGTTTCCCGTGAAACTCAAGATAGAAGAGGCTCTTAGCTTTCAGGAATTTGTAAGTTTACAAGGG ACAGGTGCCAACGCCGATGTGATTAGTTGTGGCGACAACATACTAGTATATGTTGCTAGCTACAATGATGTTGATAGTCTTGGCAAGCTCCTTGTGC AAAAGGGATACAAAGTGTCGAAGATTGATGGAAGAACAATGAAGAGTGGAGGAACTGAAATAATCACTGAAGGTACTTCAGTGAAAAAGCATTTCAT AGTCGCAACTAATATTATTGAGAATGGTGTAACCATTGACATTGATGTAGTTGTGGATTTTGGGACTAAGGTTGTACCAGTTTTGGATGTGGACAAT AGAGCGGTGCAGTACAACAAAACTGTGGTGAGTTATGGGGAGCGCATCCAAAGACTCGGTAGAGTTGGGCGACACAAGGAAGGAGTAGCACTTCGAA TTGGCCAAACAAATAAAACACTGGTTGAAATTCCAGAAATGGTTGCCACTGAAGCTGCCTTTCTATGCTTCATGTACAATTTGCCAGTGACAACACA GAGTGTTTCAACCACACTGCTGGAAAATGCCACATTATTACAAGCTAGAACTATGGCACAGTTTGAGCTATCATATTTTTACACAATTAATTTTGTG CGATTTGATGGTAGTATGCATCCAGTCATACATGACAAGCTGAAGCGCTTTAAGCTACACACTTGTGAGACATTCCTCAATAAGTTGGCGATCCCAA ATAAAGGCTTATCCTCTTGGCTTACGAGTGGAGAGTATAAGCGACTTGGTTACATAGCAGAGGATGCTGGCATAAGAATCCCATTCGTGTGCAAAGA AATTCCAGACTCCTTGCATGAGGAAATTTGGCACATTGTAGTCGCCCATAAAGGTGACTCGGGTATTGGGAGGCTCACTAGCGTACAGGCAGCAAAG GTTGTTTATACTCTGCAAACGGATGTGCACTCAATTGCGAGGACTCTAGCATGCATCAATAGACTCATAGCACATGAACAAATGAAGCAGAGTCATT TTGAAGCCGCAACTGGGAGAGCATTTTCCTTCACAAATTACTCAATACAAAGCATATTTGACACGCTGAAAGCAAATTATGCTACAAAGCATACGAA AGAAAATATTGCAGTGCTTCAGCAGGCAAAAGATCAATTGCTAGAGTTTTCGAACCTAGCAAAGGATCAAGATGTCACGGGTATCATCCAAGACTTC AATCACCTGGAAACTATCTATCTCCAATCAGATAGCGAAGTGGCTAAGCATCTGAAGCTTAAAAGTCACTGGAATAAAAGCCAAATCACTAGGGACA TCATAATAGCTTTGTCTGTGTTAATTGGTGGTGGATGGATGCTTGCAACGTACTTCAAGGACAAGTTCAATGAACCAGTCTATTTCCAAGGGAAGAA GAATCAGAAGCACAAGCTTAAGATGAGAGAGGCGCGTGGGGCTAGAGGGCAATATGAGGTTGCAGCGGAGCCAGAGGCGCTAGAACATTACTTTGGA 
AGCGCATATAATAACAAAGGAAAGCGCAAGGGCACCACGAGAGGAATGGGTGCAAAGTCTCGGAAATTCATAAACATGTATGGGTTTGATCCAACTG ATTTTTCATACATTAGGTTTGTGGATCCATTGACAGGTCACACTATTGATGAGTCCACAAACGCACCTATTGATTTAGTGCAGCATGAGTTTGGAAA GGTTAGAACACGCATGTTAATTGACGATGAGATAGAGCCTCAAAGTCTTAGCACCCACACCACAATCCATGCTTATTTGGTGAATAGTGGCACGAAG AAAGTTCTTAAGGTTGATTTAACACCACACTCGTCGCTACGTGCGAGTGAGAAATCAACAGCAATAATGGGATTTCCTGAAAGGGAGAATGAATTGC GTCAAACCGGCATGGCAGTGCCAGTGGCTTATGATCAATTGCCACCAAAGAGTGAGGACTTGACGTTTGAAGGAGAAAGCTTGTTTAAGGGACCACG TGATTACAACCCGATATCGAGCACCATTTGTCACTTGACGAATGAATCTGATGGGCACACAACATCGTTGTATGGTATTGGATTTGGTCCCTTCATC ATTACAAACAAGCACTTGTTTAGAAGAAATAATGGAACACTGTTGGTCCAATCACTACATGGTGTATTCAAGGTCAAGAACACCACGACTTTGCAAC AACACCTCATTGATGGGAGGGACATGATAATTATTCGCATGCCTAAGGATTTCCCACCATTTCCTCAAAAGCTGAAATTTAGAGAGCCACAAAGGGA AGAGCGCATATGTCTTGTGACAACCAACTTCCAAACTAAGAGCATGTCTAGCATGGTGTCAGACACTAGTTGCACATTCCCTTCATCTGATGGCATA TTCTGGAAGCATTGGATTCAAACCAAGGATGGGCAGTGTGGCAGTCCATTAGTATCAACTAGAGATGGGTTCATTGTTGGTATACACTCAGCATCGA ATTTCACCAACACAAACAATTATTTCACAAGCGTGCCGAAAAACTTCATGGAATTGTTGACAAATCAGGAGGCGCAGCAGTGGGTTAGTGGTTGGCG ATTAAATGCTGACTCAGTATTGTGGGGGGGCCATAAAGTTTTCATGAGCAAACCTGAAGAGCCTTTTCAGCCAGTTAAGGAAGCGACTCAACTCATG AGTGAATTGGTGTACTCGCAAGGGGAGAAGAGGAAATGGGTCGTGGAAGCACTGTCAGGGAACTTGAGGCCAGTGGCTGAGTGTCCCAGTCAGTTAG TCACAAAGCATGTGGTTAAAGGAAAGTGTCCCCTCTTTGAGCTCTACTTGCAGTTGAATCCAGAAAAGGAAGCATATTTTAAACCGATGATGGGAGC ATATAAGCCAAGTCGACTTAATAGAGAGGCGTTCCTCAAGGACATTCTAAAATATGCTAGTGAAATTGAGATTGGGAATGTGGATTGTGACTTGCTG GAGCTTGCAATAAGCATGCTCATCACAAAGCTCAAGGCGTTAGGATTCCCAACTGTGAACTACATCACTGACCCAGAGGAAATTTTTAGTGCATTGA ATATGAAAGCAGCTATGGGAGCACTATACAAAGGCAAGAAGAAAGAAGCTCTCAGCGAGCTCACACTAGATGAGCAGGAGGCAATGCTCAAAGCAAG TTGCCTGCGACTGTATACGGGAAAGCTGGGAATTTGGAATGGCTCATTGAAAGCAGAGTTGCGTCCAATTGAGAAGGTTGAAAACAACAAAACGCGA ACTTTCACAGCAGCACCAATAGACACTCTTCTTGCTGGTAAAGTTTGCGTGGATGATTTCAACAATCAATTTTATGATCTCAACATAAAGGCACCAT GGACAGTTGGTATGACTAAGTTTTATCAGGGGTGGAATGAATTGATGGAGGCTTTACCAAGTGGGTGGGTGTATTGTGACGCTGATGGTTCGCAATT CGACAGTTCCTTGACTCCATTCCTCATTAATGCTGTATTGAAAGTGCGACTTGCCTTCATGGAGGAATGGGATATTGGTGAGCAAATGCTGCGAAAT TTGTACACTGAGATAGTGTATACACCAATCCTCACACCGGATGGTACTATCATTAAGAAGCATAAAGGCAACAATAGCGGGCAACCTTCAACAGTGG TGGACAACACACTCATGGTCATTATTGCAATGTTATACACATGTGAGAAGTGTGGAATCAACAAGGAAGAGATTGTGTATTACGTCAATGGCGATGA CCTATTGATTGCCATTCACCCAGATAAAGCTGAGAGGTTGAGTGGATTCAAAGAATCTTTCGGAGAGTTGGGCCTGAAATATGAATTTGACTGCACC ACCAGGGACAAGACACAGTTGTGGTTCATGTCACACAGGGCTTTGGAGAGGGATGGCATGTATATACCAAAGCTAGAAGAAGAAAGGATTGTTTCTA TTTTGGAATGGGACAGATCCAAAGAGCCGTCACATAGGCTTGAAGCCATCTGTGCATCAATGATCGAAGCATGGGGTTATGACAAGCTGGTTGAAGA AATCCGCAATTTCTATGCATGGGTTTTGGAACAAGCGCCGTATTCACAGCTTGCAGAAGAAGGAAAGGCGCCATATCTGGCTGAGACTGCGCTTAAG TTTTTGTACACATCTCAGCACGGAACAAACTCTGAGATAGAAGAGTATTTAAAAGTGTTGTATGATTACGATATTCCAACGACTGAGAATCTTTATT TTCAGAGTGGCACTGTGGGTGCTGGTGTTGACGCTGGTAAGAAGAAAGATCAAAAGGATGATAAAGTCGCTGAGCAGGCTTCAAAGGATAGGGATGT TAATGCTGGAACTTCAGGAACATTCTCAGTTCCACGAATAAATGCTATGGCCACAAAACTTCAATATCCAAGGATGAGGGGAGAGGTGGTTGTAAAC TTGAATCACCTTTTAGGATACAAGCCACAGCAAATTGATTTGTCAAATGCTCGAGCCACACATGAGCAGTTTGCCGCGTGGCATCAGGCAGTGATGA CAGCCTATGGAGTGAATGAAGAGCAAATGAAAATATTGCTAAATGGATTTATGGTGTGGTGCATAGAAAATGGGACTTCCCCAAATTTGAACGGAAC TTGGGTTATGATGGATGGTGAGGAGCAAGTTTCATACCCGCTGAAACCAATGGTTGAAAACGCGCAGCCAACACTGAGGCAAATTATGACACACTTC AGTGACCTGGCTGAAGCGTATATTGAGATGAGGAATAGGGAGCGACCATACATGCCTAGGTATGGTCTACAGAGAAACATTACAGACATGAGTTTGT CACGCTATGCGTTCGACTTCTATGAGCTAACTTCAAAAACACCTGTTAGAGCGAGGGAGGCGCATATGCAAATGAAAGCTGCTGCAGTACGAAACAG TGGAACTAGGTTATTTGGTCTTGATGGCAACGTGGGTACTGCAGAGGAAGACACTGAACGGCACACAGCGCACGATGTGAACCGTAACATGCACACA CTATTAGGGGTCCGCCAGTGATAGTTTCTGCGTGTCTTTGCTTTCCGCTTTTAAGCTTATTGTAATATATATGAATAGCTATTCACAGTGGGACTTG GTCTTGTGTTGAATGGTATCTTATATGTTTTAATATGTCTTATTAGTCTCATTACTTAGGCGAACGACAAAGTGAGGTCACCTCGGTCTAATTCTCC TATGTAGTGCGAGAAAAAAAAAAAAAAAAAAAAAAAAAAAAAAAAAAAAAAAAAAA

\section{Cistron borders are underlined. Sequences fused to the Ros1 cDNA 5' and 3' termini are on yellow background.}

\section{$>$ TEV-Ros1(Nlb/CP)}

GAAAATAACAAATCTCAACACAACATATACAAAACAAACGAATCTCAAGCAATCAAGCATTCTACTTCTATTGCAGCAATTTAAATCATTTCTTTTA AAGCAAAAGCAATTTTCTGAAAATTTTCACCATTTACGAACGATAGCCATGGCACTCATCTTTGGCACAGTCAACGCTAACATCCTGAAGGAAGTGT TCGGTGGAGCTCGTATGGCTTGCGTTACCAGCGCACATATGGCTGGAGCGAATGGAAGCATTTTGAAGAAGGCAGAAGAAACCTCTCGTGCAATCAT GCACAAACCAGTGATCTTCGGAGAAGACTACATTACCGAGGCAGACTTGCCTTACACACCACTCCATTTAGAGGTCGATGCTGAAATGGAGCGGATG TATTATCTTGGTCGTCGCGCGCTCACCCATGGCAAGAGACGCAAAGTTTCTGTGAATAACAAGAGGAACAGGAGAAGGAAAGTGGCCAAAACGTACG TGGGGCGTGATTCCATTGTTGAGAAGATTGTAGTGCCCCACACCGAGAGAAAGGTTGATACCACAGCAGCAGTGGAAGACATTTGCAATGAAGCTAC CACTCAACTTGTGCATAATAGTATGCCAAAGCGTAAGAAGCAGAAAAACTTCTTGCCCGCCACTTCACTAAGTAACGTGTATGCCCAAACTTGGAGC ATAGTGCGCAAACGCCATATGCAGGTGGAGATCATTAGCAAGAAGAGCGTCCGAGCGAGGGTCAAGAGATTTGAGGGCTCGGTGCAATTGTTCGCAA GTGTGCGTCACATGTATGGCGAGAGGAAAAGGGTGGACTTACGTATTGACAACTGGCAGCAAGAGACACTTCTAGACCTTGCTAAAAGATTTAAGAA TGAGAGAGTGGATCAATCGAAGCTCACTTTTGGTTCAAGTGGCCTAGTTTTGAGGCAAGGCTCGTACGGACCTGCGCATTGGTATCGACATGGTATG TTCATTGTACGCGGTCGGTCGGATGGGATGTTGGTGGATGCTCGTGCGAAGGTAACGTTCGCTGTTTGTCACTCAATGACACATTATAGCGACAAAT CAATCTCTGAGGCATTCTTCATACCATACTCTAAGAAATTCTTGGAGTTGAGGCCAGATGGAATCTCCCATGAGTGTACAAGAGGAGTATCAGTTGA GCGGTGCGGTGAGGTGGCTGCAATCCTGACACAAGCACTTTCACCGTGTGGTAAGATCACATGCAAACGTTGCATGGTTGAAACACCTGACATTGTT GAGGGTGAGTCGGGAGACAGTGTCACCAACCAAGGTAAGCTCCTAGCAATGCTGAAAGAACAGTATCCAGATTTCCCAATGGCCGAGAAACTACTCA CAAGGTTTTTGCAACAGAAATCACTAGTAAATACAAATTTGACAGCCTGCGTGAGCGTCAAACAACTCATTGGTGACCGCAAACAAGCTCCATTCAC ACACGTACTGGCTGTCAGCGAAATTCTGTTTAAAGGCAATAAACTAACAGGGGCCGATCTCGAAGAGGCAAGCACACATATGCTTGAAATAGCAAGG TTCTTGAACAATCGCACTGAAAATATGCGCATTGGCCACCTTGGTTCTTTCAGAAATAAAATCTCATCGAAGGCCCATGTGAATAACGCACTCATGT GTGATAATCAACTTGATCAGAATGGGAATTTTATTTGGGGACTAAGGGGTGCACACGCAAAGAGGTTTCTTAAAGGATTTTTCACTGAGATTGACCC AAATGAAGGATACGATAAGTATGTTATCAGGAAACATATCAGGGGTAGCAGAAAGCTAGCAATTGGCAATTTGATAATGTCAACTGACTTCCAGACG CTCAGGCAACAAATTCAAGGCGAAACTATTGAGCGTAAAGAAATTGGGAATCACTGCATTTCAATGCGGAATGGTAATTACGTGTACCCATGTTGTT GTGTTACTCTTGAAGATGGTAAGGCTCAATATTCGGATCTAAAGCATCCAACGAAGAGACATCTGGTCATTGGCAACTCTGGCGATTCAAAGTACCT AGACCTTCCAGTTCTCAATGAAGAGAAAATGTATATAGCTAATGAAGGTTATTGCTACATGAACATTTTCTTTGCTCTACTAGTGAATGTCAAGGAA GAGGATGCAAAGGACTTCACCAAGTTTATAAGGGACACAATTGTTCCAAAGCTTGGAGCGTGGCCAACAATGCAAGATGTTGCAACTGCATGCTACT TACTTTCCATTCTTTACCCAGATGTCCTGAGTGCTGAATTACCCAGAATTTTGGTTGATCATGACAACAAAACAATGCATGTTTTGGATTCGTATGG GTCTAGAACGACAGGATACCACATGTTGAAAATGAACACAACATCCCAGCTAATTGAATTCGTTCATTCAGGTTTGGAATCCGAAATGAAAACTTAC AATGTTGGAGGGATGAACCGAGATATGGTCACACAAGGTGCAATTGAGATGTTGATCAAGTCCATATACAAACCACATCTCATGAAGCAGTTACTTG AGGAGGAGCCATACATAATTGTCCTGGCAATAGTCTCCCCTTCAATTTTAATTGCCATGTACAACTCTGGAACTTTTGAGCAGGCGTTACAAATGTG GTTGCCAAATACAATGAGGTTAGCTAACCTCGCTGCCATCTTGTCAGCCTTGGCGCAAAAGTTAACTTTGGCAGACTTGTTCGTCCAGCAGCGTAAT TTGATTAATGAGTATGCGCAGGTAATTTTGGACAATCTGATTGACGGTGTCAGGGTTAACCATTCGCTATCCCTAGCAATGGAAATTGTTACTATTA AGCTGGCCACCCAAGAGATGGACATGGCGTTGAGGGAAGGTGGCTATGCTGTGACCTCTGAAAAGGTGCATGAAATGTTGGAAAAAAACTATGTAAA GGCTTTGAAGGATGCATGGGACGAATTAACTTGGTTGGAAAAATTCTCCGCAATCAGGCATTCAAGAAAGCTCTTGAAATTTGGGCGAAAGCCTTTA ATCATGAAAAACACCGTAGATTGCGGCGGACATATAGACTTGTCTGTGAAATCGCTTTTCAAGTTCCACTTGGAACTCCTGAAGGGAACCATCTCAA 
GAGCCGTAAATGGTGGTGCAAGAAAGGTAAGAGTAGCGAAGAATGCCATGACAAAAGGGGTTTTTCTCAAAATCTACAGCATGCTTCCTGACGTCTA CAAGTTTATCACAGTCTCGAGTGTCCTTTCCTTGTTGTTGACATTCTTATTTCAAATTGACTGCATGATAAGGGCACACCGAGAGGCGAAGGTTGCT GCACAGTTGCAGAAAGAGAGCGAGTGGGACAATATCATCAATAGAACTTTCCAGTATTCTAAGCTTGAAAATCCTATTGGCTATCGCTCTACAGCGG AGGAAAGACTCCAATCAGAACACCCCGAGGCTTTCGAGTACTACAAGTTTTGCATTGGAAAGGAAGACCTCGTTGAACAGGCAAAACAACCGGAGAT AGCATACTTTGAAAAGATTATAGCTTTCATCACACTTGTATTAATGGCTTTTGACGCTGAGCGGAGTGATGGAGTGTTCAAGATACTCAATAAGTTC AAAGGAATACTGAGCTCAACGGAGAGGGAGATCATCTACACGCAGAGTTTGGATGATTACGTTACAACCTTTGATGACAATATGACAATCAACCTCG AGTTGAATATGGATGAACTCCACAAGACGAGCCTTCCTGGAGTCACTTTTAAGCAATGGTGGAACAACCAAATCAGCCGAGGCAACGTGAAGCCACA TTATAGAACTGAGGGGCACTTCATGGAGTTTACCAGAGATACTGCGGCATCGGTTGCCAGCGAGATATCACACTCACCCGCAAGAGATTTTCTTGTG AGAGGTGCTGTTGGATCTGGAAAATCCACAGGACTTCCATACCATTTATCAAAGAGAGGGAGAGTGTTAATGCTTGAGCCTACCAGACCACTCACAG ATAACGTGCACAAGCAACTGAGAAGTGAACCATTTAACTGCTTCCCAACTTTGAGGATGAGAGGGAAGTCAACTTTTGGGTCATCACCGATTACAGT CATGACTAGTGGATTCGCTTTACACCATTTTGCACGAAACATAGCTGAGGTAAAAACATACGATTTTGTCATAATTGATGAATGTCATGTGAATGAT GCTTCTGCTATAGCGTTTAGGAATCTACTGTTTGAACATGAATTTGAAGGAAAAGTCCTCAAAGTGTCAGCCACACCACCAGGTAGAGAAGTTGAAT TCACAACTCAGTTTCCCGTGAAACTCAAGATAGAAGAGGCTCTTAGCTTTCAGGAATTTGTAAGTTTACAAGGGACAGGTGCCAACGCCGATGTGAT TAGTTGTGGCGACAACATACTAGTATATGTTGCTAGCTACAATGATGTTGATAGTCTTGGCAAGCTCCTTGTGCAAAAGGGATACAAAGTGTCGAAG ATTGATGGAAGAACAATGAAGAGTGGAGGAACTGAAATAATCACTGAAGGTACTTCAGTGAAAAAGCATTTCATAGTCGCAACTAATATTATTGAGA ATGGTGTAACCATTGACATTGATGTAGTTGTGGATTTTGGGACTAAGGTTGTACCAGTTTTGGATGTGGACAATAGAGCGGTGCAGTACAACAAAAC TGTGGTGAGTTATGGGGAGCGCATCCAAAGACTCGGTAGAGTTGGGCGACACAAGGAAGGAGTAGCACTTCGAATTGGCCAAACAAATAAAACACTG GTTGAAATTCCAGAAATGGTTGCCACTGAAGCTGCCTTTCTATGCTTCATGTACAATTTGCCAGTGACAACACAGAGTGTTTCAACCACACTGCTGG AAAATGCCACATTATTACAAGCTAGAACTATGGCACAGTTTGAGCTATCATATTTTTACACAATTAATTTTGTGCGATTTGATGGTAGTATGCATCC AGTCATACATGACAAGCTGAAGCGCTTTAAGCTACACACTTGTGAGACATTCCTCAATAAGTTGGCGATCCCAAATAAAGGCTTATCCTCTTGGCTT ACGAGTGGAGAGTATAAGCGACTTGGTTACATAGCAGAGGATGCTGGCATAAGAATCCCATTCGTGTGCAAAGAAATTCCAGACTCCTTGCATGAGG AAATTTGGCACATTGTAGTCGCCCATAAAGGTGACTCGGGTATTGGGAGGCTCACTAGCGTACAGGCAGCAAAGGTTGTTTATACTCTGCAAACGGA TGTGCACTCAATTGCGAGGACTCTAGCATGCATCAATAGACTCATAGCACATGAACAAATGAAGCAGAGTCATTTTGAAGCCGCAACTGGGAGAGCA TTTTCCTTCACAAATTACTCAATACAAAGCATATTTGACACGCTGAAAGCAAATTATGCTACAAAGCATACGAAAGAAAATATTGCAGTGCTTCAGC AGGCAAAAGATCAATTGCTAGAGTTTTCGAACCTAGCAAAGGATCAAGATGTCACGGGTATCATCCAAGACTTCAATCACCTGGAAACTATCTATCT CCAATCAGATAGCGAAGTGGCTAAGCATCTGAAGCTTAAAAGTCACTGGAATAAAAGCCAAATCACTAGGGACATCATAATAGCTTTGTCTGTGTTA ATTGGTGGTGGATGGATGCTTGCAACGTACTTCAAGGACAAGTTCAATGAACCAGTCTATTTCCAAGGGAAGAAGAATCAGAAGCACAAGCTTAAGA TGAGAGAGGCGCGTGGGGCTAGAGGGCAATATGAGGTTGCAGCGGAGCCAGAGGCGCTAGAACATTACTTTGGAAGCGCATATAATAACAAAGGAAA GCGCAAGGGCACCACGAGAGGAATGGGTGCAAAGTCTCGGAAATTCATAAACATGTATGGGTTTGATCCAACTGATTTTTCATACATTAGGTTTGTG GATCCATTGACAGGTCACACTATTGATGAGTCCACAAACGCACCTATTGATTTAGTGCAGCATGAGTTTGGAAAGGTTAGAACACGCATGTTAATTG ACGATGAGATAGAGCCTCAAAGTCTTAGCACCCACACCACAATCCATGCTTATTTGGTGAATAGTGGCACGAAGAAAGTTCTTAAGGTTGATTTAAC ACCACACTCGTCGCTACGTGCGAGTGAGAAATCAACAGCAATAATGGGATTTCCTGAAAGGGAGAATGAATTGCGTCAAACCGGCATGGCAGTGCCA GTGGCTTATGATCAATTGCCACCAAAGAGTGAGGACTTGACGTTTGAAGGAGAAAGCTTGTTTAAGGGACCACGTGATTACAACCCGATATCGAGCA CCATTTGTCACTTGACGAATGAATCTGATGGGCACACAACATCGTTGTATGGTATTGGATTTGGTCCCTTCATCATTACAAACAAGCACTTGTTTAG AAGAAATAATGGAACACTGTTGGTCCAATCACTACATGGTGTATTCAAGGTCAAGAACACCACGACTTTGCAACAACACCTCATTGATGGGAGGGAC ATGATAATTATTCGCATGCCTAAGGATTTCCCACCATTTCCTCAAAAGCTGAAATTTAGAGAGCCACAAAGGGAAGAGCGCATATGTCTTGTGACAA CCAACTTCCAAACTAAGAGCATGTCTAGCATGGTGTCAGACACTAGTTGCACATTCCCTTCATCTGATGGCATATTCTGGAAGCATTGGATTCAAAC CAAGGATGGGCAGTGTGGCAGTCCATTAGTATCAACTAGAGATGGGTTCATTGTTGGTATACACTCAGCATCGAATTTCACCAACACAAACAATTAT TTCACAAGCGTGCCGAAAAACTTCATGGAATTGTTGACAAATCAGGAGGCGCAGCAGTGGGTTAGTGGTTGGCGATTAAATGCTGACTCAGTATTGT GGGGGGGCCATAAAGTTTTCATGAGCAAACCTGAAGAGCCTTTTCAGCCAGTTAAGGAAGCGACTCAACTCATGAGTGAATTGGTGTACTCGCAAGG GGAGAAGAGGAAATGGGTCGTGGAAGCACTGTCAGGGAACTTGAGGCCAGTGGCTGAGTGTCCCAGTCAGTTAGTCACAAAGCATGTGGTTAAAGGA AAGTGTCCCCTCTTTGAGCTCTACTTGCAGTTGAATCCAGAAAAGGAAGCATATTTTAAACCGATGATGGGAGCATATAAGCCAAGTCGACTTAATA GAGAGGCGTTCCTCAAGGACATTCTAAAATATGCTAGTGAAATTGAGATTGGGAATGTGGATTGTGACTTGCTGGAGCTTGCAATAAGCATGCTCAT CACAAAGCTCAAGGCGTTAGGATTCCCAACTGTGAACTACATCACTGACCCAGAGGAAATTTTTAGTGCATTGAATATGAAAGCAGCTATGGGAGCA CTATACAAAGGCAAGAAGAAAGAAGCTCTCAGCGAGCTCACACTAGATGAGCAGGAGGCAATGCTCAAAGCAAGTTGCCTGCGACTGTATACGGGAA AGCTGGGAATTTGGAATGGCTCATTGAAAGCAGAGTTGCGTCCAATTGAGAAGGTTGAAAACAACAAAACGCGAACTTTCACAGCAGCACCAATAGA CACTCTTCTTGCTGGTAAAGTTTGCGTGGATGATTTCAACAATCAATTTTATGATCTCAACATAAAGGCACCATGGACAGTTGGTATGACTAAGTTT TATCAGGGGTGGAATGAATTGATGGAGGCTTTACCAAGTGGGTGGGTGTATTGTGACGCTGATGGTTCGCAATTCGACAGTTCCTTGACTCCATTCC TCATTAATGCTGTATTGAAAGTGCGACTTGCCTTCATGGAGGAATGGGATATTGGTGAGCAAATGCTGCGAAATTTGTACACTGAGATAGTGTATAC ACCAATCCTCACACCGGATGGTACTATCATTAAGAAGCATAAAGGCAACAATAGCGGGCAACCTTCAACAGTGGTGGACAACACACTCATGGTCATT ATTGCAATGTTATACACATGTGAGAAGTGTGGAATCAACAAGGAAGAGATTGTGTATTACGTCAATGGCGATGACCTATTGATTGCCATTCACCCAG ATAAAGCTGAGAGGTTGAGTGGATTCAAAGAATCTTTCGGAGAGTTGGGCCTGAAATATGAATTTGACTGCACCACCAGGGACAAGACACAGTTGTG GTTCATGTCACACAGGGCTTTGGAGAGGGATGGCATGTATATACCAAAGCTAGAAGAAGAAAGGATTGTTTCTATTTTGGAATGGGACAGATCCAAA GAGCCGTCACATAGGCTTGAAGCCATCTGTGCATCAATGATCGAAGCATGGGGTTATGACAAGCTGGTTGAAGAAATCCGCAATTTCTATGCATGGG TTTTGGAACAAGCGCCGTATTCACAGCTTGCAGAAGAAGGAAAGGCGCCATATCTGGCTGAGACTGCGCTTAAGTTTTTGTACACATCTCAGCACGG AACAAACTCTGAGATAGAAGAGTATTTAAAAGTGTTGTATGATTACGATATTCCAACGACTGAGAATCTTTATTTTCAGTCAGGTACAATGGAAAAG AATTGTCGTGGAGTGAGAAAAGGTACTTGGACCAAAGAAGAAGACACTCTCTTGAGGCAATGTATAGAAGAGTATGGTGAAGGGAAATGGCATCAAG TTCCACACAGAGCAGGGTTGAACCGGTGTAGGAAGAGTTGCAGGCTGAGGTGGTTGAATTATCTGAGGCCAAATATCAAAAGAGGTCGGTTTTCGAG AGATGAAGTGGACCTAATTGTGAGGCTTCATAAGCTGTTGGGTAACAAATGGTCGCTGATTGCTGGTAGAATCCTGGAAGGACAGCTAATGACGTG AAGAACTTTTGGAATACTCATGTGGGGAAGAATTTAGGCGAGGATGGAGAACGATGCCGGAAAAATGTTATGAACACAAAAACCATTAAGCTGACTA АTATCGTAAGACCCCGAGCTCGGACCTTCACCGGATTGCACGTTACTTGGCCGAGAGAAGTCGGAAAAACCGATGAATTTTCAAATGTCCGGTTAAC AACTGATGAGATTCCAGATTGTGAGAAGCAAACGCAATTTTACAATGATGTTGCGTCGCCACAAGATGAAGTTGAAGACTGCATTCAGTGGTGGAGT AAGTTGCTAGAAACAACGGAGGATGGGGAATTAGGAAACCTATTCGAGGAGGCCCAACAAATTGGAAATACTACAGAGAACCTCTACTTTCAAAGTG GCACTGTGGGTGCTGGTGTTGACGCTGGTAAGAAGAAAGATCAAAAGGATGATAAAGTCGCTGAGCAGGCTTCAAAGGATAGGGATGTTAATGCTGG AACTTCAGGAACATTCTCAGTTCCACGAATAAATGCTATGGCCACAAAACTTCAATATCCAAGGATGAGGGGAGAGGTGGTTGTAAACTTGAATCAC CTTTTAGGATACAAGCCACAGCAAATTGATTTGTCAAATGCTCGAGCCACACATGAGCAGTTTGCCGCGTGGCATCAGGCAGTGATGACAGCCTATG GAGTGAATGAAGAGCAAATGAAAATATTGCTAAATGGATTTATGGTGTGGTGCATAGAAAATGGGACTTCCCCAAATTTGAACGGAACTTGGGTTAT GATGGATGGTGAGGAGCAAGTTTCATACCCGCTGAAACCAATGGTTGAAAACGCGCAGCCAACACTGAGGCAAATTATGACACACTTCAGTGACCTG GCTGAAGCGTATATTGAGATGAGGAATAGGGAGCGACCATACATGCCTAGGTATGGTCTACAGAGAAACATTACAGACATGAGTTTGTCACGCTATG CGTTCGACTTCTATGAGCTAACTTCAAAAACACCTGTTAGAGCGAGGGAGGCGCATATGCAAATGAAAGCTGCTGCAGTACGAAACAGTGGAACTAG GTTATTTGGTCTTGATGGCAACGTGGGTACTGCAGAGGAAGACACTGAACGGCACACAGCGCACGATGTGAACCGTAACATGCACACACTATTAGGG GTCCGCCAGTGATAGTTTCTGCGTGTCTTTGCTTTCCGCTTTTAAGCTTATTGTAATATATATGAATAGCTATTCACAGTGGGACTTGGTCTTGTGT TGAATGGTATCTTATATGTTTTAATATGTCTTATTAGTCTCATTACTTAGGCGAACGACAAAGTGAGGTCACCTCGGTCTAATTCTCCTATGTAGTG CGAGAAAAAAAAAAAAAAAAAAAAAAAAAAAAAAAAAAAAAAAAAAAAA

\section{Cistron borders are underlined. Sequences fused to the Ros1 cDNA 5' and 3' termini are on yellow background.}




\section{$>$ TEV-GFP-Ros1}

GAAAATAACAAATCTCAACACAACATATACAAAACAAACGAATCTCAAGCAATCAAGCATTCTACTTCTATTGCAGCAATTTAAATCATTTCTTTTA AAGCAAAAGCAATTTTCTGAAAATTTTCACCATTTACGAACGATAGCCATGGCACTCATCTTTGGCACAGTCAACGCTAACATCCTGAAGGAAGTGT TCGGTGGAGCTCGTATGGCTTGCGTTACCAGCGCACATATGGCTGGAGCGAATGGAAGCATTTTGAAGAAGGCAGAAGAGACCTCTCGTGCAATCAT GCACAAACCAGTGATCTTCGGAGAAGACTACATTACCGAGGCAGACTTGCCTTACACACCACTCCATTTAGAGGTCGATGCTGAAATGGAGCGGATG TATTATCTTGGTCGTCGCGCGCTCACCCATGGCAAGAGACGCAAAGTTTCTGTGAATAACAAGAGGAACAGGAGAAGGAAAGTGGCCAAAACGTACG TGGGGCGTGATTCCATTGTTGAGAAGATTGTAGTGCCCCACACCGAGAGAAAGGTTGATACCACAGCAGCAGTGGAAGACATTTGCAATGAAGCTAC CACTCAACTTGTGCATAATAGTATGCCAAAGCGTAAGAAGCAGAAAAACTTCTTGCCCGCCACTTCACTAAGTAACGTGTATGCCCAAACTTGGAGC ATAGTGCGCAAACGCCATATGCAGGTGGAGATCATTAGCAAGAAGAGCGTCCGAGCGAGGGTCAAGAGATTTGAGGGCTCGGTGCAATTGTTCGCAA GTGTGCGTCACATGTATGGCGAGAGGAAAAGGGTGGACTTACGTATTGACAACTGGCAGCAAGAGACACTTCTAGACCTTGCTAAAAGATTTAAGAA TGAGAGAGTGGATCAATCGAAGCTCACTTTTGGTTCAAGTGGCCTAGTTTTGAGGCAAGGCTCGTACGGACCTGCGCATTGGTATCGACATGGTATG TTCATTGTACGCGGTCGGTCGGATGGGATGTTGGTGGATGCTCGTGCGAAGGTAACGTTCGCTGTTTGTCACTCAATGACACATTATAGCGACAAA TEGTGAGCAAAGEGCAAGAAGCTETTCACCGGGGTGGTECCCATCCTGETCGAGCTGGACGGCGACGTAAAACGECCACAAGTTCAGCGTGTCCGGCGA

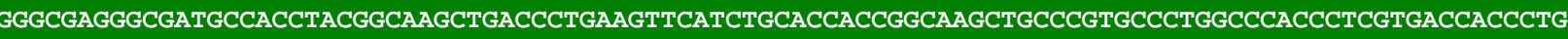
ACCTACGGCGTGCA GTGCTTCAGCCGCTACCCCGACCACATGAAGCAGCACGACTTCTTCAAGTCCGCCATGCCCGAAGGCTACGTCCAGGAGCGCA CCATCTTCTTCAAGGACGACGGCAACTACAAGACCCGCGCCGAGGTGAAGTTCGAGGGCGACACCCTGGTGAACCGCATCGAGCTGAAGGGCATCGA СTTCAAGGAGGACGGCAACATCCTGGGGCACAAGCTGGAGTACAACTACAACAGCCACAACGTCTATATCATGGCCGACAAGCAGAAGAACGGCATC AAGGTGAACTTCAAGATCCGCCACAACATCGAGGACGGCAGCGTGCAGCTCGCCGACCACTACCAGCAGAACACCCCCATCGGCGACGGCCCCGTGC

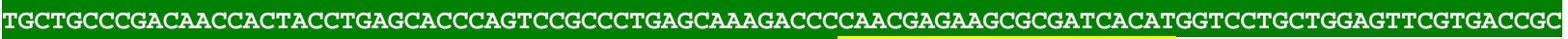
СЕССGGGATCACTCTCGECATGGACGAGCTETACAAGTACTCAGACCTCGECGGAGAAAACTTGTACTTCCAAAGCGACAAATCAATCTCTGAGGCA TTCTTCATACCATACTCTAAGAAATTCTTGGAGTTGAGACCAGATGGAATCTCCCATGAGTGTACAAGAGGAGTATCAGTTGAGCGGTGCGGTGAGG TGGCTGCAATCCTGACACAAGCACTTTCACCGTGTGGTAAGATCACATGCAAACGT TGCATGGTTGAAACACCTGACATTGTTGAGGGTGAGTCGGG AGACAGTGTCACCAACCAAGGTAAGCTCCTAGCAATGCTGAAAGAACAGTATCCAGATTTCCCAATGGCCGAGAAACTACTCACAAGGTTTTTGCAA CAGAAATCACTAGTAAATACAAATTTGACAGCCTGCGTGAGCGTCAAACAACTCATTGGTGACCGCAAACAAGCTCCATTCACACACGTACTGGCTG TCAGCGAAATTCTGTTTAAAGGCAATAAACTAACAGGGGCCGATCTCGAAGAGGCAAGCACACATATGCTTGAAATAGCAAGGTTCTTGAACAATCG CACTGAAAATATGCGCATTGGCCACCTTGGTTCTTTCAGAAATAAAATCTCATCGAAGGCCCATGTGAATAACGCACTCATGTGTGATAATCAACTT GATCAGAATGGGAATTTTATTTGGGGACTAAGGGGTGCACACGCAAAGAGGTTTCTTAAAGGATTTTTCACTGAGATTGACCCAAATGAAGGATACG ATAAGTATGTTATCAGGAAACATATCAGGGGTAGCAGAAAGCTAGCAATTGGCAATTTGATAATGTCAACTGACTTCCAGACGCTCAGGCAACAAAT TCAAGGCGAAACTATTGAGCGTAAAGAAATTGGGAATCACTGCATTTCAATGCGGAATGGTAATTACGTGTACCCATGTTGTTGTGTTACTCTTGAA GATGGTAAGGCTCAATATTCGGATCTAAAGCATCCAACGAAGAGACATCTGGTCATTGGCAACTCTGGCGATTCAAAGTACCTAGACCTTCCAGTTC TCAATGAAGAGAAAATGTATATAGCTAATGAAGGTTATTGCTACATGAACATTTTCTTTGCTCTACTAGTGAATGTCAAGGAAGAGGATGCAAAGGA CTTCACCAAGTTTATAAGGGACACAATTGTTCCAAAGCTTGGAGCGTGGCCAACAATGCAAGATGTTGCAACTGCATGCTACTTACTTTCCATTCTT TACCCAGATGTCCTGAGTGCTGAATTACCCAGAATTTTGGTTGATCATGACAACAAAACAATGCATGTTTTGGATTCGTATGGGTCTAGAACGACAG GATACCACATGTTGAAAATGAACACAACATCCCAGCTAATTGAATTCGTTCATTCAGGTTTGGAATCCGAAATGAAAACTTACAATGTTGGAGGGAT GAACCGAGATATGGTCACACAAGGTGCAATTGAGATGTTGATCAAGTCCATATACAAACCACATCTCATGAAGCAGTTACTTGAGGAGGAGCCATAC ATAATTGTCCTGGCAATAGTCTCCCCTTCAATTTTAATTGCCATGTACAACTCTGGAACTTTTGAGCAGGCGTTACAAATGTGGTTGCCAAATACAA TGAGGTTAGCTAACCTCGCTGCCATCTTGTCAGCCTTGGCGCAAAAGTTAACTTTGGCAGACTTGTTCGTCCAGCAGCGTAATTTGATTAATGAGTA TGCGCAGGTAATTTTGGACAATCTGATTGACGGTGTCAGGGTTAACCATTCGCTATCCCTAGCAATGGAAATTGTTACTATTAAGCTGGCCACCCAA GAGATGGACATGGCGTTGAGGGAAGGTGGCTATGCTGTGACCTCTGAAAAGGTGCATGAAATGTTGGAAAAAAACTATGTAAAGGCTTTGAAGGATG CATGGGACGAATTAACTTGGTTGGAAAAATTCTCCGCAATCAGGCATTCAAGAAAGCTCTTGAAATTTGGGCGAAAGCCTTTAATCATGAAAAACAC CGTAGATTGCGGCGGACATATAGACTTGTCTGTGAAATCGCTTTTCAAGTTCCACTTGGAACTCCTGAAGGGAACCATCTCAAGAGCCGTAAATGGT GGTGCAAGAAAGGTAAGAGTAGCGAAGAATGCCATGACAAAAGGGGTTTTTCTCAAAATCTACAGCATGCTTCCTGACGTCTACAAGTTTATCACAG TCTCGAGTGTCCTTTCCTTGTTGTTGACATTCTTATTTCAAATTGACTGCATGATAAGGGCACACCGAGAGGCGAAGGTTGCTGCACAGTTGCAGAA AGAGAGCGAGTGGGACAATATCATCAATAGAACTTTCCAGTATTCTAAGCTTGAAAATCCTATTGGCTATCGCTCTACAGCGGAGGAAAGACTCCAA TCAGAACACCCCGAGGCTTTCGAGTACTACAAGTTTTGCATTGGAAAGGAAGACCTCGTTGAACAGGCAAAACAACCGGAGATAGCATACTTTGAAA AGATTATAGCTTTCATCACACTTGTATTAATGGCTTTTGACGCTGAGCGGAGTGATGGAGTGTTCAAAGATACTCAATAAGTTCAAAGGAATACTGAG CTCAACGGAGAGGGAGATCATCTACACGCAGAGTTTGGATGATTACGTTACAACCTTTGATGACAATATGACAATCAACCTCGAGTTGAATATGGAT GAACTCCACAAGACGAGCCTTCCTGGAGTCACTTTTAAGCAATGGTGGAACAACCAAATCAGCCGAGGCAACGTGAAGCCACATTATAGAACTGAGG GGCACTTCATGGAGTTTACCAGAGATACTGCGGCATCGGTTGCCAGCGAGATATCACACTCACCCGCAAGAGATTTTCTTGTGAGAGGTGCTGTTGG ATCTGGAAAATCCACAGGACTTCCATACCATTTATCAAAGAGAGGGAGAGTGTTAATGCTTGAGCCTACCAGACCACTCACAGATAACGTGCACAAG CAACTGAGAAGTGAACCATTTAACTGCTTCCCAACTTTGAGGATGAGAGGGAAGTCAACTTTTGGGTCATCACCGATTACAGTCATGACTAGTGGAT TCGCTTTACACCATTTTGCACGAAACATAGCTGAGGTAAAAACATACGATTTTGTCATAATTGATGAATGTCATGTGAATGATGCTTCTGCTATAGC GTTTAGGAATCTACTGTTTGAACATGAATTTGAAGGAAAAGTCCTCAAAGTGTCAGCCACACCACCAGGTAGAGAAGTTGAATTCACAACTCAGTTT CCCGTGAAACTCAAGATAGAAGAGGCTCTTAGCTTTCAGGAATTTGTAAGTTTACAAGGGACAGGTGCCAACGCCGATGTGATTAGTTGTGGCGACA ACATACTAGTATATGTTGCTAGCTACAATGATGTTGATAGTCTTGGCAAGCTCCTTGTGCAAAAGGGATACAAAGTGTCGAAGATTGATGGAAGAAC AATGAAGAGTGGAGGAACTGAAATAATCACTGAAGGTACTTCAGTGAAAAAGCATTTCATAGTCGCAACTAATATTATTGAGAATGGTGTAACCATT GACATTGATGTAGTTGTGGATTTTGGGACTAAGGTTGTACCAGTTTTGGATGTGGACAATAGAGCGGTGCAGTACAACAAAACTGTGGTGAGTTATG GGGAGCGCATCCAAAGACTCGGTAGAGTTGGGCGACACAAGGAAGGAGTAGCACTTCGAATTGGCCAAACAAATAAAACACTGGTTGAAATTCCAGA AATGGTTGCCACTGAAGCTGCCTTTCTATGCTTCATGTACAATTTGCCAGTGACAACACAGAGTGTTTCAACCACACTGCTGGAAAATGCCACATTA TTACAAGCTAGAACTATGGCACAGTTTGAGCTATCATATTTTTACACAATTAATTTTGTGCGATTTGATGGTAGTATGCATCCAGTCATACATGACA AGCTGAAGCGCTTTAAGCTACACACTTGTGAGACATTCCTCAATAAGTTGGCGATCCCAAATAAAGGCTTATCCTCTTGGCTTACGAGTGGAGAGTA TAAGCGACTTGGTTACATAGCAGAGGATGCTGGCATAAGAATCCCATTCGTGTGCAAAGAAATTCCAGACTCCTTGCATGAGGAAATTTGGCACATT GTAGTCGCCCATAAAGGTGACTCGGGTATTGGGAGGCTCACTAGCGTACAGGCAGCAAAGGTTGTTTATACTCTGCAAACGGATGTGCACTCAATTG CGAGGACTCTAGCATGCATCAATAGACTCATAGCACATGAACAAATGAAGCAGAGTCATTTTGAAGCCGCAACTGGGAGAGCATTTTCCTTCACAAA TTACTCAATACAAAGCATATTTGACACGCTGAAAGCAAATTATGCTACAAAGCATACGAAAGAAAATATTGCAGTGCTTCAGCAGGCAAAAGATCAA TTGCTAGAGTTTTCGAACCTAGCAAAGGATCAAGATGTCACGGGTATCATCCAAGACTTCAATCACCTGGAAACTATCTATCTCCAATCAGATAGCG AAGTGGCTAAGCATCTGAAGCTTAAAAGTCACTGGAATAAAAGCCAAATCACTAGGGACATCATAATAGCTTTGTCTGTGTTAATTGGTGGTGGATG GATGCTTGCAACGTACTTCAAGGACAAGTTCAATGAACCAGTCTATTTCCAAGGGAAGAAGAATCAGAAGCACAAGCTTAAGATGAGAGAGGCGCGT GGGGCTAGAGGGCAATATGAGGTTGCAGCGGAGCCAGAGGCGCTAGAACATTACTTTGGAAGCGCATATAATAACAAAGGAAAGCGCAAGGGCACCA CGAGAGGAATGGGTGCAAAGTCTCGGAAATTCATAAACATGTATGGGTTTGATCCAACTGATTTTTCATACATTAGGTTTGTGGATCCATTGACAGG TCACACTATTGATGAGTCCACAAACGCACCTATTGATTTAGTGCAGCATGAGTTTGGAAAGGTTAGAACACGCATGTTAATTGACGATGAGATAGAG CCTCAAAGTCTTAGCACCCACACCACAATCCATGCTTATTTGGTGAATAGTGGCACGAAGAAAGTTCTTAAGGTTGATTTAACACCACACTCGTCGC TACGTGCGAGTGAGAAATCAACAGCAATAATGGGATTTCCTGAAAGGGAGAATGAATTGCGTCAAACCGGCATGGCAGTGCCAGTGGCTTATGATCA ATTGCCACCAAAGAGTGAGGACTTGACGTTTGAAGGAGAAAGCTTGTTTAAGGGACCACGTGATTACAACCCGATATCGAGCACCATTTGTCACTTG ACGAATGAATCTGATGGGCACACAACATCGTTGTATGGTATTGGATTTGGTCCCTTCATCATTACAAACAAGCACTTGTTTAGAAGAAATAATGGAA CACTGTTGGTCCAATCACTACATGGTGTATTCAAGGTCAAGAACACCACGACTTTGCAACAACACCTCATTGATGGGAGGGACATGATAATTATTCG 
CATGCCTAAGGATTTCCCACCATTTCCTCAAAAGCTGAAATTTAGAGAGCCACAAAGGGAAGAGCGCATATGTCTTGTGACAACCAACTTCCAAACT AAGAGCATGTCTAGCATGGTGTCAGACACTAGTTGCACATTCCCTTCATCTGATGGCATATTCTGGAAGCATTGGATTCAAACCAAGGATGGGCAGT GTGGCAGTCCATTAGTATCAACTAGAGATGGGTTCATTGTTGGTATACACTCAGCATCGAATTTCACCAACACAAACAATTATTTCACAAGCGTGCC GAAAAACTTCATGGAATTGTTGACAAATCAGGAGGCGCAGCAGTGGGTTAGTGGTTGGCGATTAAATGCTGACTCAGTATTGTGGGGGGGCCATAAA GTTTTCATGAGCAAACCTGAAGAGCCTTTTCAGCCAGTTAAGGAAGCGACTCAACTCATGAGTGAATTGGTGTACTCGCAAGGGGAGAAGAGGAAAT GGGTCGTGGAAGCACTGTCAGGGAACTTGAGGCCAGTGGCTGAGTGTCCCAGTCAGTTAGTCACAAAGCATGTGGTTAAAGGAAAGTGTCCCCTCTT TGAGCTCTACTTGCAGTTGAATCCAGAAAAGGAAGCATATTTTAAACCGATGATGGGAGCATATAAGCCAAGTCGACTTAATAGAGAGGCGTTCCTC AAGGACATTCTAAAATATGCTAGTGAAATTGAGATTGGGAATGTGGATTGTGACTTGCTGGAGCTTGCAATAAGCATGCTCATCACAAAGCTCAAGG CGTTAGGATTCCCAACTGTGAACTACATCACTGACCCAGAGGAAATTTTTAGTGCATTGAATATGAAAGCAGCTATGGGAGCACTATACAAAGGCAA GAAGAAAGAAGCTCTCAGCGAGCTCACACTAGATGAGCAGGAGGCAATGCTCAAAGCAAGTTGCCTGCGACTGTATACGGGAAAGCTGGGAATTTGG AATGGCTCATTGAAAGCAGAGTTGCGTCCAATTGAGAAGGTTGAAAACAACAAAACGCGAACTTTCACAGCAGCACCAATAGACACTCTTCTTGCTG GTAAAGTTTGCGTGGATGATTTCAACAATCAATTTTATGATCTCAACATAAAGGCACCATGGACAGTTGGTATGACTAAGTTTTATCAGGGGTGGAA TGAATTGATGGAGGCTTTACCAAGTGGGTGGGTGTATTGTGACGCTGATGGTTCGCAATTCGACAGTTCCTTGACTCCATTCCTCATTAATGCTGTA TTGAAAGTGCGACTTGCCTTCATGGAGGAATGGGATATTGGTGAGCAAATGCTGCGAAATTTGTACACTGAGATAGTGTATACACCAATCCTCACAC CGGATGGTACTATCATTAAGAAGCATAAAGGCAACAATAGCGGGCAACCTTCAACAGTGGTGGACAACACACTCATGGTCATTATTGCAATGTTATA CACATGTGAGAAGTGTGGAATCAACAAGGAAGAGATTGTGTATTACGTCAATGGCGATGACCTATTGATTGCCATTCACCCAGATAAAGCTGAGAGG TTGAGTGGATTCAAAGAATCTTTCGGAGAGTTGGGCCTGAAATATGAATTTGACTGCACCACCAGGGACAAGACACAGTTGTGGTTCATGTCACACA GGGCTTTGGAGAGGGATGGCATGTATATACCAAAGCTAGAAGAAGAAAGGATTGTTTCTATTTTGGAATGGGACAGATCCAAAGAGCCGTCACATAG GCTTGAAGCCATCTGTGCATCAATGATCGAAGCATGGGGTTATGACAAGCTGGTTGAAGAAATCCGCAATTTCTATGCATGGGTTTTGGAACAAGCG CCGTATTCACAGCTTGCAGAAGAAGGAAAGGCGCCATATCTGGCTGAGACTGCGCTTAAGTTTTTGTACACATCTCAGCACGGAACAAACTCTGAGA TAGAAGAGTATTTAAAAGTGTTGTATGATTACGATATTCCAACGACTGAGAATCTTTATTTTCAGTCAGGTACAATGGAAAAGAATTGTCGTGGAGT GAGAAAAGGTACTTGGACCAAAGAAGAAGACACTCTCTTGAGGCAATGTATAGAAGAGTATGGTGAAGGGAAATGECATCAAGTTCCACACAGAGCA GGGTTGAACCGGTGTAGGAAGAGTTGCAGGCTGAGGTGGTTGAATTATCTGAGGCCAAATATCAAAAGAGGTCGGTTTTCGAGAGATGAAGTGGACC TAATTGTAGGCTTCATAAGCTGTTGGGTAACAAATGGTCGCTGATTGCTGGTAGAATTCCTGGAAGGACAGCTAATGACGTGAAGAACTTTTGGAA TACTCATGTGGGGAAGAATTPGGCGAGGATGGAGAACGATGCCGGAAAAATGTTATGAACACAAAAACCATTAAGCTGACTAATATCGTAAGACCC

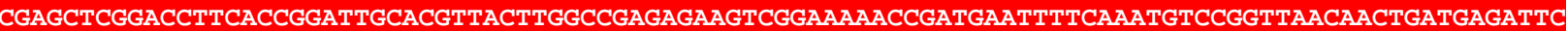
CAGATTGTGAGAAGCAAACGCAATTTTACAATGATGTTGCGTCGCCACAAGATGAAGTTGAAGACTGCATTCAGTGGTGGAGTAAGTTGCTAGAAAC

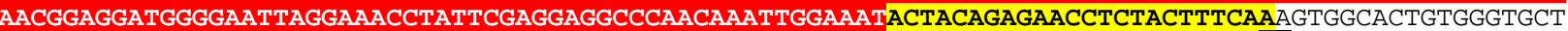
GGTGTTGACGCTGGTAAGAAGAAAGATCAAAAGGATGATAAAGTCGCTGAGCAGGCTTCAAAGGATAGGGATGTTAATGCTGGAACTTCAGGAACAT TCTCAGTTCCACGAATAAATGCTATGGCCACAAAACTTCAATATCCAAGGATGAGGGGAGAGGTGGTTGTAAACTTGAATCACCTTTTAGGATACAA GCCACAGCAAATTGATTTGTCAAATGCTCGAGCCACACATGAGCAGTTTGCCGCGTGGCATCAGGCAGTGATGACAGCCTATGGAGTGAATGAAGAG CAAATGAAAATATTGCTAAATGGATTTATGGTGTGGTGCATAGAAAATGGGACTTCCCCAAATTTGAACGGAACTTGGGTTATGATGGATGGTGAGG AGCAAGTTTCATACCCGCTGAAACCAATGGTTGAAAACGCGCAGCCAACACTGAGGCAAATTATGACACACTTCAGTGACCTGGCTGAAGCGTATAT TGAGATGAGGAATAGGGAGCGACCATACATGCCTAGGTATGGTCTACAGAGAAACATTACAGACATGAGTTTGTCACGCTATGCGTTCGACTTCTAT GAGCTAACTTCAAAAACACCTGTTAGAGCGAGGGAGGCGCATATGCAAATGAAAGCTGCTGCAGTACGAAACAGTGGAACTAGGTTATTTGGTCTTG ATGGCAACGTGGGTACTGCAGAGGAAGACACTGAACGGCACACAGCGCACGATGTGAACCGTAACATGCACACACTATTAGGGGTCCGCCAGTGATA GTTTCTGCGTGTCTTTGCTTTCCGCTTTTAAGCTTATTGTAATATATATGAATAGCTATTCACAGTGGGACTTGGTCTTGTGTTGAATGGTATCTTA TATGTTTTAATATGTCTTATTAGTCTCATTACTTAGGCGAACGACAAAGTGAGGTCACCTCGGTCTAATTCTCCTATGTAGTGCGAGAAAAAAAAAA AAAAAAAAAAAAAAAAAAAAAAAAAAAAAAAAAAA

\section{Cistron borders are underlined. GFP cDNA is on green background. Sequences fused to the GFP and Ros1 cDNA 5' and 3' termini are on yellow background.}

\section{$>$ TuMV-Ros1}

AAAAATATAAAAACTCAACACAACATACACAAAACGATAAAAGCAAACGCAGACCTTTCGAAGCACTCAAGCAATCAAAGATTCTCAAATCTTTCAT CGTTATCAAAGCAATCACCAACAGCAAACCAAATGGCAGTAGTTACATTCGCATCGGCTATCACCAACGCCATCACCAGCAAGCCAGCATCCACCGG AATGGTACAGTTTGGGAGTTTCCCACCAGTGCCATTGCGATCCACCACCGTCACCACAGTCGCCACTTCAGTGGCACAACCTAAACTGTACACAGTG CAGTTTGGAAGCCTTGACCCAGTAGTTGTCAAGGGTGGAGCAGGGTCCTTTGCTAAGGCAACACGCCAGCAGCCTAACGTTGAAATAGACGTTAGCC TCAGTGAAGCTGCAGCTCTGGAGGTTGCGAAACCTAGATCAAATGCCGTGTTGAGGATGCACGAGGAAGCAAACAAGGAGAGAGCACTCTTTTTGGA CTGGGAGGCTAGTTTGAAGAGAAGCTCGTATGGAATTGCCGAGAACGAGAAAGTTGTAATGACAACTCGTGGCGTCAGTAAGATAGTGCCCAGGAGT TCAAGGGCAATGAAGCAAAAGCGCGCAAGGGAAAGGCGTAGAGCGCAGCAACCAATTATACTAAAGTGGGAGCCCAAATTGAGCGGGATCTCAATTG GAGGAGGACTCTCTGCGAGCGCGATCGAAATAGAAGAGGTTCACACAAAGTGGCCGCTTCACAAGACACCGTCAATGAAGAAGAGAACGGTGCACAG AATATGCAGGATGAATGACCAAGGAGTTGACATGTTGACACGATCCCTGGTTAAGATCTTCAAGACTAAGAGTGCCAACATTGAGTACATCGGAAAG AAGTCGATTAAGGTCGATTTCATCAGAAAAGAACGGACGAAATTCGCAAGGATCCAAGTAGCACACTTACTCGGGAAGAGAGCGCAGCGCGACTTAT CAGCTGGAATGGAAGAAAACCATTTTATTGATATTCTCAGCAGGTACTCGGGTAACAAAACAACCATAAATCCAGGAGTGGTTTGCGCAGGTTGGAG TGGCATAGTCGTTAGAGATGGAATTCTAACCCAGAAACGAAGCAGAAGCCCATCAGAGGCCTTTGTAATTAGAGGTGAGCACGAAGGCAAGTTGTAC GATGCCAGGATTAAAGTCACGAGGACAATGAGTCACAAGATTGTGCACTTTAGTGCAGCAGGAGCCAACTTCTGGAAAGGCTTCGACAGATGCTTTC TTGCATACCGTAGTGACAATCGCGAGCATACATGCTATTCAGGGCTAGATGTTACTGAGTGCGGCGAGGTGGCAGCACTGATGTGCTTGGCTATGTT CCCATGCGGAAAGATAACCTGCCCTGACTGTGTAACAGATAGTGAGCTATCCCAAGGGCAAGCAAGTGGGCCATCCATGAAGCACAGGTTAACGCAG CTACGCGATGTCATCAAGTCAAGCTACCCACGCTTCAAGCATGCAGTGCAGATACTAGATATGTATGAGCAATCACTGAGCAGTGCAAACGAAAACT ACCAAGATTTCGCAGAAATCCAGAGTATAAGTGATGGAGTTGAGAAAGCTGCATTCCCACACGTTAATAAGCTAAACGCAATATTGATCAAGGGGGC CACAGCGACAGGGGAGGAATTCTCACAGGCCACGAAACATTTGCTTGAGATAGCACGATACCTGAAGAACAGAACTGAGAACATTGAGAAGGGTTCA TTGAAGTCCTTTCGTAACAAGATCTCCCAGAAAGCGCACATCAACCCAACACTAATGTGCGACAACCAGCTCGATAGAAATGGAAATTTCATATGGG GTGAGAGAGGATACCATGCAAAACGATTCTTCAGCAACTACTTTGAGATAATCGATCCAAAGAAAGGCTACACCCAATACGAAACAAGAGTGGTACC AAATGGGTCACGGAAACTTGCAATCGGCAAACTAATAGTCTCAACGAACTTTGAAGTTCTAAGGGAGCAGATGAAAGGCGAACCGGTAGAACCATAC CCAGTAACAGTCGAGTGCGTGAGCAAGTTACAGGGTGACTTCGTTCATGCATGTTGTTGTGTCACAACAGAATCAGGCGACCCAGTCTTGTCTGAAA TTAAGATGCCAACCAAACACCACCTAGTGATTGGCAACAGCGGCGATCCAAAGTACATAGATCTCCCTGAGATCGAGGAGAATAAGATGTACATAGC GAAAGAAGGTTATTGTTACATCAATATCTTCCTAGCTATGCTAGTAAATGTTAAGGAGTCGCAGGCAAAGGAGTTCACGAAAGTTGTTAGGGATAAA CTAGTTGGCGAACTTGGCAAGTGGCCCACTCTGTTAGATGTAGCAACCGCTTGTTATTTCCTGAAGGTATTTTACCCAGACGTTGCTAACGCCGAAT TACCACGCATGTTAGTGGACCATAAGACAAAGATAATTCATGTCGTTGATTCATATGGGTCACTGTCAACTGGATATCATGTCCTTAAGACAAATAC TGTGGAACAACTCATCAAATTCACAAGATGCAATTTGGAGTCAAGCTTAAAACACTACCGTGTCGGAGGGACAGAATGGGAGGACACTCATGGAGCC AGCAACATAGATAATCCACAATGGTGCATCAAGAGGCTCAAAAAAGGAGTCTATAGACCAAAGCAACTAAAAGAAGACATGTTGGCAAACCCTTTCT TACCATTATATGCTTTACTGTCACCAGGTGTCATCCTGGCATTTTACAATAGTGGATCTCTAGAGTACTTGATGAACCATTACATCAGGGTTGACAG TAATGTCGCCGTTTTGTTGGTTGTTTTGAAATCTCTAGCTAAGAAAGTGTCAACTAGTCAGAGTGTGTTAGCCCAGCTTCAAATCATTGAACGAAGT CTACCAGAACTCATCGAAGCTAAGGCTAATGTTAATGGACCAGATGACGCAGCCACTCGCGCGTGTAACAGATTCATGGGCATGCTTTTGCACATGG CAGAACCAAACTGGGAGCTTGCGGATGGTGGATACACAATTCTGAGAGATCATAGCATCTCCATTTTGGAAAAAAGTTATCTACAAATCTTGGACGA 
GGCATGGAACGAGTTAAGTTGGTCGGAGCGCTGTGCTATAAGATACTACTCGTCAAAGCAAGCAATCTTTACACAGAGAGATTTGCCAATGAAAAGC GAAGCCGATTTAGGCGGCAGATACAGCGTGTCAGTCATGTCATCTTACGAATGGGGTAAGCAATGTGTTAAAAACGTACACTCTAGTATAGGTAGTA GATTACGTAGTGGTATGTCTTGGACTGGTAGCAAGGTGTCGAATAGCGTGTGTAGGACTATTAATTATTTAGTACCAGATGTGTTCAAGTTTATGAA TGTGCTCGTTTGTATCAGCTTACTAATCAAGATGACCGCCGAGGCGAATCACATCGTCACCACGCAAAGAAGGCTCAAACTGGATATTGAGGAGACA GAGCGCAGGAAAATAGAATGGGAACTTGCATTCCACCATGCCATTCTGACGCAGAGTGCAGGTCAACACCCAACGATAGATGAGTTCAGAGCATACA TCGCTGACAAGGCACCACATCTAAGTGAGCATATCGAGCCTGAAGAAAAGGCAGTGGTTCATCAAGCAAAGAGACAATCCGAGCAAGAACTCGAACG TATAATAGCATTTGTTGCATTGGTGCTCATGATGTTTGACGCAGAACGAAGCGACTGTGTCACAAAGATTCTTAACAAGCTTAAGGGACTAGTCGCC ACTGTCGAACCTACAGTTTACCATCAGACTCTCAATGATATAGAGGATGACTTGAGCGAGAGGAATCTCTTCGTCGATTTCGAGCTTAGCAGTGAGG GCGATGTGCTCCAACAACTTCCAGCTGAAAAGACATTTGCTTCATGGTGGAGCCATCAACTAAGCAGAGGATTCACAATCCCACACTACAGGACAGA AGGGAAGTTCATGACTTTTACCAGAGCAACTGCCACGGAAGTCGCGAGTAAAATAGCACACGAAAGTGACAGAGACATATTGCTAATGGGAGCAGTA GGATCAGGTAAGTCAACTGGCTTGCCATATCATCTCTCCAGAAAAGGGAATGTATTGCTCCTTGAGCCAACTCGGCCACTTGCAGAAAACGTACATA AGCAGCTGTCGCAGGCACCATTCCATCAGAACACAACTCTTAGGATGCGCGGATTAACAGCATTCGGGTCGGCGCCAATCTCAGTAATGACCAGTGG TTTTGCACTCAATTACTTTGCAAACAATAGAATGCGCATTGAAGAATTTGACTTTGTCATATTTGATGAATGTCACGTTCATGATGCTAATGCAATG GCGATGAGATGTTTGCTGCATGAGTGTGACTATTCTGGCAAAATTATCAAAGTTTCAGCCACACCACCAGGTCGAGAAGTTGAGTTCTCCACTCAAT ACCCCGTGTCAATAAGCACAGAAGACACACTATCGTTCCAGGATTTTGTGAACGCACAGGGTAGTGGAAGCAACTGTGATGTGATTTCAAAAGGAGA CAATATTCTCGTGTATGTAGCAAGCTACAATGAGGTAGACGCGCTTTCAAAACTTTTAATTGAAAGAGACTTCAAAGTCACGAAGGTTGATGGAAGA ACGATGAAAGTTGGAAACATCGAGATCACCACAAGTGGAACACCTAGCAAGAAGCACTTCATAGTCGCAACTAATATCATCGAGAACGGTGTTACTC TGGACATCGATGTGGTTGCTGATTTTGGAACGAAGGTACTCCCATACCTTGACACAGACAGTAGAATGCTTAGCACAACAAAGGCAAGCATCAATTA TGGGGAGCGCATCCAAAGACTAGGAAGAGTCGGACGACACAAGCCAGGTCACGCCCTGCGAATAGGTCACACAGAGAAAGGGTTGAGCGAAATTCCA AGTTGTATTGCAACAGAAGCAGCTTTGAAGTGCTTCACTTATGGGCTTCCAGTGATCACCAACAACGTCTCGACAAGCATTCTGGGTAATGTAACGG TGAAGCAGGCACGAACAATGTCTGTGTTTGAAATAACACCGTTCTACACAAGCCAAGTGGTGAGATATGATGGCTCCATGCACCCACAGGTGCACGA ACTTCTAAAGAGATTCAAACTCAGAGACTCTGAGATTGTTTTGAACAAATTAGCCATACCTCACCGAGGAGTGAACGCTTGGCTCACAGCCAGTGAG TATGCACGACTTGGCGCTAATGTTGAAGATAGGCGTGACGTGCGAATCCCTTTTATGTGTCGCGACATCCCAGAAAAACTTCATCTAGACATGTGGG ATGTGATTGTCAAATTCAAAGGTGATGCGGGTTTTGGTCGGCTTTCAAGCGCCAGTGCGAGCAAGGCAGCTTATACTCTACAGACGGACGTCAACTC CATACAGCGTACAGTCACTATCATAGATACACTAATCGCTGAGGAGAGAAGAAAGCAGGAATACTTCAAGACGGTAACCTCCAACTGTGTTTCTTCT TCGAACTTCTCACTGCAGAGCATAACAAATGCGATAAAATCTCGTATGATGAAAGATCACACGTGCGAGAACATATCAGTGCTTGAAGGAGCGAAGT CACAGTTACTTGAGTTTAGAAACCTGAATGCTGATCACTCATTTGCCACTAAAACCGATGGAATATCTCGACATTTCATGAGTGAGTATGGAGCGCT TGAGGCAGTTCACCATCAAAACATCAGCGACATGAGCAAATTCCTTAAGCTTAAGGGCAAATGGAACAAGACGCTAATCACGCGAGATGTGTTGGTG CTTTGTGGAGTTCTTGGAGGTGGATTGTGGATGGTTATTCAGCACCTGCGGTCAAAGATCTCTGAACCCGTAACCCACGAAGCGAAAGGCAAGAGGC AAAGACAGAAGCTAAAGTTTCGCAATGCCCGAGACAACAAGATGGGTAGAGAAGTATACGGAGATGATGACACCATAGAGCACTTCTTTGGTGATGC CTACACAAAGAAAGGGAAGAGCAAGGGCAGGACACGTGGTATCGGGCACAAAAACAGGAAGTTCATCAATATGTATGGATTTGATCCTGAAGATTTC TCTGCAGTTCGTTTCGTGGATCCACTCACAGGAGCGACGTTGGATGACAACCCGTTCACAGACATCACCCTTGTGCAAGAGCACTTTGGTAACATAA GAATGAACTTGCTCGGGGAGGATGAGTTGGATCCAAATGAAATACGTGTGAATAAGACAATTCAGGCCTACTACATGAACAATAAAACAGGCAAGGC TTTGAAGGTGGATCTGACACCACACATACCTCTCAAGGTGTGCGATCTTCACGCAACCATTGCTGGATTCCCAGAGCGAGAAAACGAACTGAGGCAG ACTGGAAAGGCTCAGCCCATTAACATAGACGAGGTGCCAAGAGCTAATAATGGACTCGTCCCAGTGGACCACGAGAGTAACTCCATGTTCAGAGGGT TGCGTGACTACAACCCAATATCAAACAACATTTGTCATCTCACAAATGTTTCAGATGGAGCATCAAACTCGTTATATGGAGTCGGTTTCGGACCACT CATATTAACAAACCGACACCTCTTTGAGCGGAATAACGGTGAGCTCGTAATAAAATCACGACATGGTGAGTTCGTGATTAAAAACACAACTCAGCTA CATTTGCTACCGATTCCAGACAGAGATCTTCTGCTAATCCGGTTACCAAAGGACGTCCCACCCTTTCCACAGAAATTGGGTTTCAGGAAACCTGAGA AGGGTGAGCGAATTTGCATGGTGGGATCCAACTTCCAAACCAAGAGCATAACGAGTATAGTCTCTGAGACTAGCACAATAATGCCAGTGGAAAACAG TCAGTTTTGGAAACACTGGATTAGCACGAAAGACGGTCAATGCGGAAGTCCAATGGTGAGCACGAAAGACGGAAAAATACTTGGATTACACAGTCTG GCAAACTTCCAAAACTCCATCAATTACTTTGCTGCTTTCCCAGACGATTTTGCCGAGAAGTATCTTCATACCATTGAGGCACACGAGTGGGTCAAGC ATTGGAAATATAACACTAGTGCCATCAGTTGGGGCTCTTTGAATATACAAGCATCGCAACCGTCAGGCTTGTTCAAAGTAAGCAAGCTAATCTCAGA CCTCGACAGCACGGCAGTCTATGCACAAACCCAGCAGAATCGGTGGATGTTCGAGCAACTCAATGGGAACCTGAAAGCGGTAGCACACTGCCCTAGC CAGCTTGTGACAAAGCACACAGTTAAAGGAAAATGTCAGATGTTTGACTTGTATCTCAAGTTGCATGATGAAGCACGAGAGTATTTCCAACCGATGC TGGGCCAGTATCAAAAGAGCAAACTCAATCGAGAAGCATATGCAAAGGATCTTCTAAAATATGCGACGCCAATCGAAGCAGGAAACATCGACTGCGA TCTGTTTGAAAAGACAGTTGAAATAGTCGTATCAGATCTGCGAGGTTATGGTTTCGAAACATGCAATTATGTCACTGATGAGAATGACATATTCGAA GCTCTTAACATGAAATCCGCAGTTGGAGCGTTGTATAAAGGAAAGAAGAAGGATTACTTCGCTGAGTTCACACCTGAGATGAAAGAAGAAATATTGA AGCAAAGTTGTGAACGACTCTTCTTAGGAAAGATGGGAGTGTGGAACGGCTCGTTGAAGGCAGAGTTACGACCACTAGAAAAAGTGGAAGCAAACAA AACACGGACGTTTACTGCCGCACCACTAGACACACTACTGGGTGGAAAGGTCTGCGTGGATGATTTCAACAACCAGTTCTATGATCACAACCTTAGA GCTCCTTGGAGTGTTGGCATGACAAAGTTTTATTGTGGTTGGGATCGTTTGTTAGAGTCGTTACCAGATGGTTGGGTGTATTGTGATGCTGATGGCT CACAGTTTGACAGCTCGCTATCACCATACTTGATCAATGCAGTACTCAACATCCGCTTAGGGTTCATGGAAGAGTGGGACGTAGGGGAGATAATGCT GAGAAATTTGTACACCGAAATCGTGTATACCCCTATCTCTACACCAGATGGTACACTCGTCAAGAAGTTCAAAGGAAACAATAGCGGACAGCCATCG ACTGTTGTAGACAACACGCTCATGGTCATACTGGCAGTCAACTATTCACTCAAGAAAAGCGGAATTCCAAGTGAGTTGCGCGACAGCATCATCAGAT TCTTCGTCAACGGAGATGATTTACTGCTAAGCGTACACCCAGAGTATGAGTATATCCTTGACACTATGGCAGACAACTTTCGTGAATTGGGCCTGAA GTATACTTTCGACTCAAGGACCAGGGAAAAAGGAGACCTTTGGTTTATGTCGCACCAAGGGCACAAAAGGGAGGGAATCTGGATTCCCAAGCTCGAG CCAGAGCGAATAGTATCGATTTTAGAATGGGATCGGTCGAAAGAGCCATGCCATCGACTAGAGGCAATCTGCGCAGCGATGATTGAATCGTGGGGAT ACGACAAGTTAACTCACGAGATACGTAAGTTTTATGCGTGGATGATTGAACAAGCTCCATTTAGCTCCTTAGCACAAGAAGGGAAAGCTCCTTACAT AGCGGAAACAGCGCTGAGGAAGCTCTACCTTGATAAGGAACCAGCTCAAGAGGATCTCACCCATTATTTGCAAGCAATCTTTGAGGATTATGAAGAT GGTGCTGAGACTTGCGTATACCATCAAGCCATGGAAAAGAATTGTCGTGGAGTGAGAAAAGGTACTTGGACCAAAGAAGAAGACACTCTCTTGAGGC AATGTATAGAAGAGTATGGTGAAGGGAAATGCCATCAAGTTCCACACAGAGCAGGGTTGAACCGGTGTAGGAAGAGTTGCAGGCTGAGGTGGTTGAA TTATCTGAGGCCAAATATCAAAAGAGGTCG TTTTCGAGAGATGAAGTGGACCTAATTGTGAGGCTTCATAAGCTGTTGGGTAACAAATGGTCGCTE ATTGCTGGTAGAATTCCTGGAAGGACAGCTAATGACGTGAAGAACTTTTGGAATACTCATGTGGGGAAGAATTTAGGCGAGGATGGAGAACGATGCC GGAAAAATGTTATGAACACAAAAACCATTAAGCTGACTAATATCGTAAGACCCCGAGCTCGGACCTTCACCGGATTGCACGTTACTTGGCCGAGAGA AGTCGGAAAAACCGATGAATTTTCAAATGTCCGGTPAACAACTGATGAGATTCCAGATTGTGAGAAGCAAACGCAATTTTACAATGATGTTGCGTCG CCACAAGATGAAGTTGAAGACTGCATTCAGTGGTGGAGTAAGTTGCTAGAAACAACGGAGGATGGGGAATTAGGAAACCTATTCGAGGAGGCCCAAC AAATTGGAAATGCTAGCTGTGTTTATCACCAGGCAGAGACGCCTGATGCAGGTTTGACAGATGAGCAGAAGCAGGCGGAAAAGGAGAAGAAGGAGAG AGAGAAGGCAGAAAAGGAACGAGAGAGGCAAAAACAGTTGGCGCTCAAGAAAGGCAAGGATGTTGCGCAAGAAGAGGGGAAACGCGACAGGGAAGTG AACGCCGGAACCTCTGGAACTTTCAGTGTACCCAGACTTAAGAGCCTAACAAGCAAAATGCGCGTGCCAAGATACGAGCAGAGAGTGGCTTTAAACC TTGATCATCTAATCCTATACACGCCGGAGCAGACGGATCTATCCAACACACGGTCAACGCGAAAGCAGTTTGACACATGGTTTGAAGGTGTAATGGC CGATTACGAACTGACGGAGGACAAAATGCAAATTATTCTCAATGGTTTAATGGTCTGGTGCATTGAGAACGGAACCTCCCCGAACATAAACGGAATG TGGGTGATGATGGACGGCGATGATCAGGTGGAATTCCCGATCAAACCGCTCATTGACCACGCCAAACCCACATTTAGGCAAATAATGGCCCATTTCA GTGACGTAGCTGAAGCGTACATTGAAAAGCGTAACCAAGACCGACCATACATGCCACGATATGGTCTTCAGCGCAATTTAACCGACATGAGCCTAGC TCGATACGCGTTTGACTTCTATGAAATGACTTCTAGAACTCCAATACGTGCGAGAGAAGCACACATCCAGATGAAAGCAGCAGCACTGCGTGGCGCA AATAACAATTTGTTCGGCTTGGATGGAAACGTTGGTGCAACGGTAGAGAACACGGAGAGGCATACGACCGAGGACGTTAATCGGAACATGCATAACT TACTTGGCGTTAAGGGGTTATGAAGTTGTATGTTGGTAGACTATAAGTATTTAAGTTTACTCGTTAGTATTCTCGCTTATGGGAAATATGTAAGTTT GTTAAAGCAGCCAGTGTGACTTTGTCATGTGTGTTGTTGTTACTTTCTATATTTTCGCCGAACATTTTATTGGTGTTAGCGCATGTGGTGAGGATCA TCCTCGATTGCCTTAACATTGATATGATGCAAGGGACAAAAAAAAAAAAAAAAAAAAAAAAAAAAAAAAAAAAAAAAA 


\section{Sequences fused to the Ros1 cDNA 5' and 3' termini are on yellow background.}

\section{$>$ TMV-Ros1}

GTATTTTTACAACAATTACCAACAACAACAAACAACAGACAACATTACAATTACTATTTACAATTACAATGGCATACACACAGACAGCTACCACATC AGCTTTGCTGGACACTGTCCGAGGAAACAACTCCTTGGTCAATGATCTAGCAAAGCGTCGTCTTTACGACACAGCGGTTGAAGAGTTTAACGCTCGT GACCGCAGGCCCAAGGTGAACTTTTCAAAAGTAATAAGCGAGGAGCAGACGCTTATTGCTACCCGGGCGTATCCAGAATTCCAAATTACATTTTATA ACACGCAAAATGCCGTGCATTCGCTTGCAGGTGGATTGCGATCTTTAGAACTGGAATATCTGATGATGCAAATTCCCTACGGATCATTGACTTATGA CATAGGCGGGAATTTTGCATCGCATCTGTTCAAGGGACGAGCATATGTACACTGCTGCATGCCCAACCTGGACGTTCGAGACATCATGCGGCACGAA GGCCAGAAAGACAGTATTGAACTATACCTTTCTAGGCTAGAGAGAGGGGGGAAAACAGTCCCCAACTTCCAAAAGGAAGCATTTGACAGATACGCAG AAATTCCTGAAGACGCTGTCTGTCACAATACTTTCCAGACATGCGAACATCAGCCGATGCAGCAATCAGGCAGAGTGTATGCCATTGCGCTACACAG CATATATGACATACCAGCCGATGAGTTCGGGGCGGCACTCTTGAGGAAAAATGTCCATACGTGCTATGCCGCTTTCCACTTCTCCGAGAACCTGCTT CTTGAAGATTCATGCGTCAATTTGGACGAAATCAACGCGTGTTTTTCGCGCGATGGAGACAAGTTGACCTTTTCTTTTGCATCAGAGAGTACTCTTA ATTACTGTCATAGTTATTCTAATATTCTTAAGTATGTGTGCAAAACTTACTTCCCGGCCTCTAATAGAGAGGTTTACATGAAGGAGTTTTTAGTCAC CAGAGTTAATACCTGGTTTTGTAAGTTTTCTAGAATAGATACTTTTCTTTTGTACAAAGGTGTGGCCCATAAAAGTGTAGATAGTGAGCAGTTTTAT ACTGCAATGGAAGACGCATGGCATTACAAAAAGACTCTTGCAATGTGCAACAGCGAGAGAATCCTCCTTGAGGATTCATCATCAGTCAATTACTGGT TTCCCAAAATGAGGGATATGGTCATCGTACCATTATTCGACATTTCTTTGGAGACTAGTAAGAGGACGCGCAAGGAAGTCTTAGTGTCCAAGGATTT CGTGTTTACAGTGCTTAACCACATTCGAACATACCAGGCGAAAGCTCTTACATACGCAAATGTTTTGTCCTTCGTCGAATCGATTCGATCGAGGGTA ATCATTAACGGTGTGACAGCGAGGTCCGAATGGGATGTGGACAAATCTTTGTTACAATCCTTGTCCATGACGTTTTACCTGCATACTAAGCTTGCCG TTCTAAAGGATGACTTACTGATTAGCAAGTTTAGTCTCGGTTCGAAAACGGTGTGCCAGCATGTGTGGGATGAGATTTCGCTGGCGTTTGGGAACGC ATTTCCCTCCGTGAAAGAGAGGCTCTTGAACAGGAAACTTATCAGAGTGGCAGGCGACGCATTAGAGATCAGGGTGCCTGATCTATATGTGACCTTC CACGACAGATTAGTGACTGAGTACAAGGCCTCTGTGGACATGCCTGCGCTTGACATTAGGAAGAAGATGGAAGAAACGGAAGTGATGTACAATGCAC TTTCAGAATTATCGGTGTTAAGGGAGTCTGACAAATTCGATGTTGATGTTTTTTCCCAGATGTGCCAATCTTTGGAAGTTGACCCAATGACGGCAGC GAAGGTTATAGTCGCGGTCATGAGCAATGAGAGCGGTCTGACTCTCACATTTGAACGACCTACTGAGGCGAATGTTGCGCTAGCTTTACAGGATCAA GAGAAGGCTTCAGAAGGTGCATTGGTAGTTACCTCAAGAGAAGTTGAAGAACCGTCCATGAAGGGTTCGATGGCCAGAGGAGAGTTACAATTAGCTG GTCTTGCTGGAGATCATCCGGAATCGTCCTATTCTAAGAACGAGGAGATAGAGTCTTTAGAGCAGTTTCATATGGCGACGGCAGATTCGTTAATTCG TAAGCAGATGAGCTCGATTGTGTACACGGGTCCGATTAAAGTTCAGCAAATGAAAAACTTTATCGATAGCCTGGTAGCATCACTATCTGCTGCGGTG TCGAATCTCGTCAAGATCCTCAAAGATACAGCTGCTATTGACCTTGAAACCCGTCAAAAGTTTGGAGTCTTGGATGTTGCATCTAGGAAGTGGTTAA TCAAACCAACGGCCAAGAGTCATGCATGGGGTGTTGTTGAAACCCACGCGAGGAAGTATCATGTGGCGCTTTTGGAATATGATGAGCAGGGTGTGGT GACATGCGATGATTGGAGAAGAGTAGCTGTTAGCTCTGAGTCTGTTGTTTATTCCGACATGGCGAAACTCAGAACTCTGCGCAGACTGCTTCGAAAC GGAGAACCGCATGTCAGTAGCGCAAAGGTTGTTCTTGTGGACGGAGTTCCGGGCTGTGGAAAAACCAAAGAAATTCTTTCCAGGGTTAATTTTGATG AAGATCTAATTTTAGTACCTGGGAAGCAAGCCGCGGAAATGATCAGAAGACGTGCGAATTCCTCAGGGATTATTGTGGCCACGAAGGACAACGTTAA AACCGTTGATTCTTTCATGATGAATTTTGGGAAAAGCACACGCTGTCAGTTCAAGAGGTTATTCATTGATGAAGGGTTGATGTTGCATACTGGTTGT GTTAATTTTCTTGTGGCGATGTCATTGTGCGAAATTGCATATGTTTACGGAGACACACAGCAGATTCCATACATCAATAGAGTTTCAGGATTCCCGT ACCCCGCCCATTTTGCCAAATTGGAAGTTGACGAGGTGGAGACACGCAGAACTACTCTCCGTTGTCCAGCCGATGTCACACATTATCTGAACAGGAG ATATGAGGGCTTTGTCATGAGCACTTCTTCGGTTAAAAAGTCTGTTTCGCAGGAGATGGTCGGCGGAGCCGCCGTGATCAATCCGATCTCAAAACCC TTGCATGGCAAGATCTTGACTTTTACCCAATCGGATAAAGAAGCTCTGCTTTCAAGAGGGTATTCAGATGTTCACACTGTGCATGAAGTGCAAGGCG AGACATACTCTGATGTTTCACTAGTTAGGTTAACCCCTACACCGGTCTCCATCATTGCAGGAGACAGCCCACATGTTTTGGTCGCATTGTCAAGGCA CACCTGTTCGCTCAAGTACTACACTGTTGTTATGGATCCTTTAGTTAGTATCATTAGAGATCTAGAGAAACTTAGCTCGTACTTGTTAGATATGTAT AAGGTCGATGCAGGAACACAATAGCAATTACAGATTGACTCGGTGTTCAAAGGTTCCAATCTTTTTGTTGCAGCGCCAAAGACTGGTGATATTTCTG ATATGCAGTTTTACTATGATAAGTGTCTCCCAGGCAACAGCACCATGATGAATAATTTTGATGCTGTTACCATGAGGTTGACTGACATTTCATTGAA TGTCAAAGATTGCATATTGGATATGTCTAAGTCTGTTGCTGCGCCTAAGGATCAAATCAAACCACTAATACCTATGGTACGAACGGCGGCAGAAATG CCACGCCAGACTGGACTATTGGAAAATTTAGTGGCGATGATTAAAAGAAACTTTAACGCACCCGAGTTGTCTGGCATCATTGATATTGAAAATACTG CATCTTTGGTTGTAGATAAGTTTTTTGATAGTTATTTGCTTAAAGAAAAAAGAAAACCAAATAAAAATGTTTCTTTGTTCAGTAGAGAGTCTCTCAA TAGATGGTTAGAAAAGCAGGAACAGGTAACAATAGGCCAGCTCGCAGATTTTGATTTTGTGGATTTGCCAGCAGTTGATCAGTACAGACACATGATT AAAGCACAACCCAAACAAAAGTTGGACACTTCAATCCAAACGGAGTACCCGGCTTTGCAGACGATTGTGTACCATTCAAAAAAGATCAATGCAATAT TCGGCCCGTTGTTTAGTGAGCTTACTAGGCAATTACTGGACAGTGTTGATTCGAGCAGATTTTTGTTTTTCACAAGAAAGACACCAGCGCAGATTGA GGATTTCTTCGGAGATCTCGACAGTCATGTGCCGATGGATGTCTTGGAGCTGGATATATCAAAATACGACAAATCTCAGAATGAATTCCACTGTGCA GTAGAATACGAGATCTGGCGAAGATTGGGTTTCGAAGACTTCTTGGGAGAAGTTTGGAAACAAGGGCATAGAAAGACCACCCTCAAGGATTATACCG CAGGTATAAAAACTTGCATCTGGTATCAAAGAAAGAGCGGGGACGTCACGACGTTCATTGGAAACACTGTGATCATTGCTGCATGTTTGGCCTCGAT GCTTCCGATGGAGAAAATAATCAAAGGAGCCTTTTGCGGTGACGATAGTCTGCTGTACTTTCCAAAGGGTTGTGAGTTTCCGGATGTGCAACACTCC GCGAATCTTATGTGGAATTTTGAAGCAAAACTGTTTAAAAAACAGTATGGATACTTTTGCGGAAGATATGTAATACATCACGACAGAGGATGCATTG TGTATTACGATCCCCTAAAGTTGATCTCGAAACTTGGTGCTAAACACATCAAGGATTGGGAACACTTGGAGGAGTTCAGAAGGTCTCTTTGTGATGT TGCTGTTTCGTTGAACAATTGTGCGTATTACACACAGTTGGACGACGCTGTATGGGAGGTTCATAAGACCGCCCCTCCAGGTTCGTTTGTTTATAAA AGTCTGGTGAAGTATTTGTCTGATAAAGTTCTTTTTAGAAGTTTGTTTATAGATGGCTCTAGTTGTTAAAGGAAAAGTGAATATCAATGAGTTTATC GACCTGACAAAAATGGAGAAGATCTTACCGTCGATGTTTACCCCTGTAAAGAGTGTTATGTGTTCCAAAGTTGATAAAATAATGGTTCATGAGAATG AGTCATTGTCAGGGGTGAACCTTCTTAAAGGAGTTAAGCTTATTGATAGTGGATACGTCTGTTTAGCCGGTTTGGTCGTCACGGGCGAGTGGAACTT GCCTGACAATTGCAGAGGAGGTGTGAGCGTGTGTCTGGTGGACAAAAGGATGGAAAGAGCCGACGAGGCCAtTCTCGGATCTTACTACACAGCAGCT GCAAAGAAAAGATTTCAGTTCAAGGTCGTTCCCAATTATGCTATAACCACCCAGGACGCGATGAAAAACGTCTGGCAAGTTTTAGTTAATATTAGAA ATGTGAAGATGTCAGCGGGTTTCTGTCCGCTTTCTCTGGAGTTTGTGTCGGTGTGTATTGTTTATAaAAATAATATAAAATTAGGTTTGAGAGAGAA GATTACAAACGTGAGAGACGGAGGGCCCATGGAACTTACAGAAGAAGTCGTTGATGAGTTCATGGAAGATGTCCCTATGTCGATCAGGCTTGCAAAG TTTCGATCTCGAACCGGAAAAAAGAGTGATGTCCGCAAAGGGAAAAATAGTAGTAGTGATCGGTCAGTGCCGAACAAGAACTATAGAAATGTTAAGG ATTTTGGAGGAATGAGTTTTAAAAAGAATAATTTAATCGATGATGATTCGGAGGCTACTGTCGCCGAATCGGATTCGTTTTAAATAGATCTTACAGT ATCACTACTCCATCTCAGTTCGT GT TCTTGTCATTAAT TAAATGGAAAAAGAATTGTCGTGGAGTGAGAAAㅅAGGTACTTGGACCAAAAGAAGAAGAACAC TCTCTTGAGECAAATGTATAGAAGAATATGGTGAAAGGAAAATGGCATCAAATTCCACACAGAGCAGGGTTGAACCGGTGTAGGAAGAGTTECAGGCTE

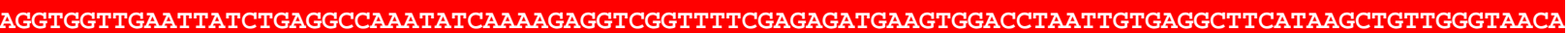
AATGGTCGCTGATTGCTGGTAGAATTCCTGGAAGGACAGCTAATGACGTGAAGAACTTPTTGAATACTCATGTGGGAAGAATTTAGGCGAGGATGG

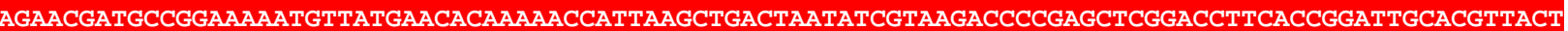
TEGCCGAGAGAAGTCGGAAAAACCGATGAATTTTCAAATTTCCGGTTAACAACTGATGAGATTCCAGATTGTGAGAAGCAAACGCAATTTTACAATE ATETTECGTCGCCACAAGATGAAGTTGAAAACTECATTCAGTGGTGGAGTAAGTTGCTAGAAACAACGGAGGATGGGGAATTAGGAAACCTATTCGA GGAGECCCA소CAA속TGGAAAAATTAACTCGAGGGGTAGTCAAGATGCATAATAAATAACGGATTGTGTCCGTAATCACACGTGGTGCGTACGATAACG CATAGTGTTTTTCCCTCCACTTAAATCGAAGGGTTGTGTCTTGGATCGCGCGGGTCAAATGTATATGGTTCATATACATCCGCAGGCACGTAATAAA GCGAGGGGTTCGGGTCGAGGTCGGCTGTGAAACTCGAAAAGGTTCCGGAAAACAAAAAAGAGAGTGGTAGGTAATAGTGTTAATAATAAGAAAATAA ATAATAGTGGTAAGAAAGGTTTGAAAGTTGAGGAAATTGAGGATAATGTAAGTGATGACGAGTCTATCGCGTCATCGAGTACGTTTTAATCAATATG CCTTATACAATCAACTCTCCGAGCCAATTTGTTTACTTAAGTTCCGCTTATGCAGATCCTGTGCAGCTGATCAATCTGTGTACAAATGCATTGGGTA ACCAGTTTCAAACGCAACAAGCTAGGACAACAGTCCAACAGCAATTTGCGGATGCCTGGAAACCTGTGCCTAGTATGACAGTGAGATTTCCTGCATC GGATTTCTATGTGTATAGATATAATTCGACGCTTGATCCGTTGATCACGGCGTTATTAAATAGCTTCGATACTAGAAATAGAATAATAGAGGTTGAT AATCAACCCGCACCGAATACTACTGAAATCGTTAACGCGACTCAGAGGGTAGACGATGCGACTGTAGCTATAAGGGCTTCAATCAATAATTTGGCTA 
ATGAACTGGTTCGTGGAACTGGCATGTTCAATCAAGCAAGCTTTGAGACTGCTAGTGGACTTGTCTGGACCACAACTCCGGCTACTTAGCTATTGTT GTGAGATTTCCTAAAATAAAGTCACTGAAGACTTAAAATTCAGGGTGGCTGATACCAAAATCAGCAGTGGTTGTTCGTCCACTTAAATATAACGATT GTCATATCTGGATCCAACAGTTAAACCATGTGATGGTGTATACTGTGGTATGGCGTAAAACAACGGAAAAGTCGCTGAAGACTTAAAATTCAGGGTG GCTGATACCAAAATCAGCAGTGGTTGTTCGTCCACTTAAAAATAACGATTGTCATATCTGGATCCAACAGTTAAACCATGTGATGGTGTATACTGTG GTATGGCGTAAACAACGGAGAGGTTCGAATCCTCCCCTAACCGCGGGTAGCGGCCCAG

\section{$>$ PVX-Ros1}

GAAAACTAAACCATACACCACCAACACAACCAAACCCACCACGCCCAATTGTTACACACCCGCTTGAAAAAGAAAGTTTAACAAATGGCCAAGGTGC GCGAGGTTTACCAATCTTTTACAGACTCCACCACAAAAACTCTCATCCAAGATGAGGCTTATAGAAACATTCGCCCCATCATGGAAAAACACAAACT AGCTAACCCTTACGCTCAAACGGTTGAAGCGGCTAATGATCTAGAGGGGTTCGGCATAGCCACCAATCCCTATAGCATTGAATTGCATACACATGCA GCCGCTAAGACCATAGAGAATAAACTTCTAGAGGTGCTTGGTTCCATCCTACCACAAGAACCTGTTACATTTATGTTTCTTAAACCCAGAAAGCTAA ACTACATGAGAAGAAACCCGCGGATCAAGGACATTTTCCAAAATGTTGCCATTGAACCAAGAGACGTAGCCAGGTACCCCAAGGAAACAATAATTGA CAAACTCACAGAGATCACAACGGAAACAGCATACATTAGTGACACTCTGCACTTCTTGGATCCGAGCTACATAGTGGAGACATTCCAAAACTGCCCA AAATTGCAAACATTGTATGCGACCTTAGTTCTCCCCGTTGAGGCAGCCTTTAAAATGGAAAGCACTCACCCGAACATATACAGCCTCAAATACTTCG GAGATGGTTTCCAGTATATACCAGGCAACCATGGTGGCGGGGCATACCATCATGAATTCGCTCATCTACAATGGCTCAAAGTGGGAAAGATCAAGTG GAGGGACCCCAAGGATAGCTTTCTCGGACATCTCAATTACACGACTGAGCAGGTTGAGATGCACACAGTGACAGTACAGTTGCAGGAATCGTTCGCG GCAAACCACTTGTACTGCATCAGGAGAGGAGACTTGCTCACACCGGAGGTGCGCACTTTCGGCCAACCTGACAGGTACGTGATTCCACCACAGATCT TCCTCCCAAAAGTTCACAACTGCAAGAAGCCGATTCTCAAGAAAACTATGATGCAGCTCTTCTTGTATGTTAGGACAGTCAAGGTCGCAAAAAATTG TGACATTTTTGCCAAAGTCAGACAATTAATTAAATCATCTGACTTGGACAAATACTCTGCTGTGGAACTGGTTTACTTAGTAAGCTACATGGAGTTC CTTGCCGATTTACAAGCTACCACCTGCTTCTCAGACACACTTTCTGGTGGCTTGCTAACAAAGACCCTTGCACCGGTGAGGGCTTGGATACAAGAGA AAAAGATGCAGCTGTTTGGTCTTGAGGACTACGCGAAGTTAGTCAAAGCAGTTGATTTCCACCCGGTGGATTTTTCTTTCAAAGTGGAAACTTGGGA CTTCAGATTCCACCCCTTGCAAGCGTGGAAAGCCTTCCGACCAAGGGAAGTGTCGGATGTAGAGGAAATGGAAAGTTTGTTCTCAGATGGGGACCTG CTTGATTGCTTCACAAGAATGCCAGCTTATGCGGTAAACGCAGAGGAAGATTTAGCTGCAATCAGGAAAACGCCCGAGATGGATGTCGGTCAAGAAG TTAAAGAGCCTGCAGGAGACAGAAATCAATACTCAAACCCTGCAGAAACTTTCCTCAACAAGCTCCACAGGAAACACAGTAGGGAGGTGAAACACCA GGCCGCAAAGAAAGCTAAACGCCTAGCTGAAATCCAGGAGTCAATGAGAGCTGAAGGTGATGCCGAACCAAATGAAATAAGCGGGACGATGGGGGCA ATACCCAGCAACGCCGAACTTCCTGGCACGAATGATGCCAGACAAGAACTCACACTCCCAACCACTAAACCTGTCCCTGCAAGGTGGGAAGATGCTT CATTCACAGATTCTAGTGTGGAAGAGGAGCAGGTTAAACTCCTTGGAAAAGAAACCGTTGAAACAGCGACGCAACAAGTCATCGAAGGACTTCCTTG GAAACACTGGATTCCTCAATTAAATGCTGTTGGATTCAAGGCGCTGGAAATTCAGAGGGATAGGAGTGGAACAATGATCATGCCCATCACAGAAATG GTCTCCGGGCTGGAAAAAGAGGACTTCCCTGAAGGAACTCCAAAAGAGTTGGCACGAGAATTGTTCGCTATGAACAGAAGCCCTGCCACCATCCCTT TGGACCTGCTTAGAGCCAGAGACTACGGCAGTGATGTAAAGAACAAGAGAATTGGTGCCATCACAAAGACACAGGCAACGAGTTGGGGCGAATACTT GACAGGAAAGATAGAAAGCTTAACTGAGAGGAAAGTTGCGACTTGTGTCATTCATGGAGCTGGAGGTTCTGGAAAAAGTCATGCCATCCAGAAGGCA TTGAGAGAAATTGGCAAGGGCTCGGACATCACTGTAGTCCTGCCGACCAATGAACTGCGGCTAGATTGGAGTAAGAAAGTGCCTAACACTGAGCCCT ATATGTTCAAGACCTCTGAAAAGGCGTTAATTGGGGGAACAGGCAGCATAGTCATCTTTGACGATTACTCAAAACTTCCTCCCGGTTACATAGAAGC CTTAGTCTGTTTCTACTCTAAAATCAAGCTAATCATTCTAACAGGAGATAGCAGACAAAGCGTCTACCATGAAACTGCTGAGGACGCCTCCATCAGG CATTTGGGACCAGCAACAGAGTACTTCTCAAAATACTGCCGATACTATCTCAATGCCACACACCGCAACAAGAAAGATCTTGCGAACATGCTTGGTG TCTACAGTGAGAGAACGGGAGTCACCGAAATCAGCATGAGCGCCGAGTTCTTAGAAGGAATCCCAACTTTGGTACCCTCGGATGAGAAGAGAAAGCT GTACATGGGCACCGGGAGGAATGACACGTTCACATACGCTGGATGCCAGGGGCTAACTAAGCCGAAGGTACAAATAGTGTTGGACCACAACACCCAA GTGTGTAGCGCGAATGTGATGTACACGGCACTTTCTAGAGCCACCGATAGGATTCACTTCGTGAACACAAGTGCAAATTCCTCTGCCTTCTGGGAAA AGTTGGACAGCACCCCTTACCTCAAGACTTTCCTATCAGTGGTGAGAGAACAAGCACTCAGGGAGTACGAGCCGGCAGAGGCAGAGCCAATTCAAGA GCCTGAGCCCCAGACACACATGTGTGTCGAGAATGAGGAGTCCGTGCTAGAAGAGTACAAAGAGGAACTCTTGGAAAAGTTTGACAGAGAGATCCAC TCTGAATCCCATGGTCATTCAAACTGTGTCCAAACTGAAGACACAACCATTCAGTTGTTTTCGCATCAACAAGCAAAAGATGAGACCCTCCTCTGGG CGACTATAGATGCGCGGCTCAAGACCAGCAATCAAGAAACAAACTTCCGAGAATTCCTGAGCAAGAAGGACATTGGGGACGTTCTGTTTTTAAACTA CCAAAAAGCTATGGGTTTACCCAAAGAGCGTATTCCTTTTTCCCAAGAGGTCTGGGAAGCTTGTGCCCACGAAGTACAAAGCAAGTACCTCAGCAAG TCAAAGTGCAACTTGATCAATGGGACTGTGAGACA GAGCCCAGACTTCGATGAAAATAAGATTATGGTATTCCTCAAGTCGCAGTGGGTCACAAAGG TGGAAAAACTAGGTCTACCCAAGATTAAGCCAGGTCAAACCATAGCAGCCTTTTACCAGCAGACTGTGATGCTTTTTGGAACTATGGCTAGGTACAT GCGATGGTTCAGACAGGCTTTCCAGCCAAAAGAAGTCTTCATAAACTGTGAGACCACGCCAGATGACATGTCTGCATGGGCCTTGAACAACTGGAAT TTCAGCAGACCTAGCTTGGCTAATGACTACACAGCTTTCGACCAGTCTCAGGATGGAGCCATGTTGCAATTTGAGGTGCTCAAAGCCAAACACCACT GCATACCAGAGGAAATCATTCAGGCATACATAGATATTAAGACTAATGCACAGATTTTCCTAGGCACGTTATCAATTATGCGCCTGACTGGTGAAGG TCCCACTTTTGATGCAAACACTGAGTGCAACATAGCTTACACCCATACAAAGTTTGACATCCCAGCCGGAACTGCTCAAGTTTATGCAGGAGACGAC TCCGCACTGGACTGTGTTCCAGAAGTGAAGCATAGTTTCCACAGGCTTGAGGACAAATTACTCCTAAAGTCAAAGCCTGTAATCACGCAGCAAAAGA AGGGCAGTTGGCCTGAGTTTTGTGGTTGGCTGATCACACCAAAAGGGGTGATGAAAGACCCAATTAAGCTCCATGTTAGCTTAAAATTGGCTGAAGC TAAGGGTGAACTCAAGAAATGTCAAGATTCCTATGAAATTGATCTGAGTTATGCCTATGACCACAAGGACTCTCTGCATGACTTGTTCGATGAGAAA CAGTGTCAGGCACACACACTCACTTGCAGAACACTAATCAAGTCAGGGAGAGGCACTGTCTCACTTTCCCGCCTCAGAAACTTTCTTTAACCGTTAA GTTACCTTAGAGATTTGAATAAGATGGATATTCTCATCAGTAGTTTGAAAAGTTTAGGTTATTCTAGGACTTCCAAATCTTTAGATTCAGGACCTTT GGTAGTACATGCAGTAGCCGGAGCCGGTAAGTCCACAGCCCTAAGGAAGTTGATCCTCAGACACCCAACATTCACCGTGCATACACTCGGTGTCCCT GACAAGGTGAGTATCAGAACTAGAGGCATACAGAAGCCAGGACCTATTCCTGAGGGCAACTTCGCAATCCTCGATGAGTATACTTTGGACAACACCA CAAGGAACTCTAACCAGGCACTTTTTGCTGACCCTTATCAGGCACCGGAGTTTAGCCTAGAGCCCCACTTCTACTTGGAAACATCATTTCGAGTTCC GAGGAAAGTGGCAGATTTGATAGCTGGCTGTGGCTTCGATTTCGAGACCAACTCACCGGAAGAAGGGCACTTAGAGATCACTGGCATATTCAAAGGG CCCCCTACTCGGAAAGGTGATAGCCATTGATGAGGAGTCTGAGACAACACTGTCCAGGCATGGTGTTGAGTTTGTTAAGCCCTGCCAAGTGACGGGA CTTGAGTTCAAAGTAGTCACTATTGTGTCTGCCGCACCAATAGAGGAAATTGGCCAGTCCACAGCTTTCTACAACGCTATCACCAGGTCAAAGGGAT TGACATATGTCCGCGCAGGGCCATAGGCTGACCGCTCCGGTCAATTCTGAAAAAGTGTACATAGTATTAGGTCTATCATTTGCTTTAGTTTCAATTA CCTTTCTGCTTTCTAGAAATAGCTTACCCCACGTCGGTGACAACATTCACAGCTTGCCACACGGAGGAGCTTACAGAGACGGCACCAAAGCAATCTT GTACAACTCCCCAAATCTAGGGTCACGAGTGAGTCTACACAACGGAAAGAACGCAGCATTTGCTGCCGTTTTGCTACTGACTTTGCTGATCTATGGA AGTAAATACATATCTCAACGCAATCATACTTGTGCTTGTGGTAACAATCATAGCAGTCATTAGCACTTCCTTAGTGAGGACTGAACCTTGTGTCATC AAGATTACTGGGGAATCAATCACAGTGTTGGCTTGCAAACTAGATGCAGAAACCATAAGGGCCATTGCCGATCTCAAGCCACTCTCCGTTGAACGGT TAAGTTTCCATTGATACTCGAAAGAGGTCAGCACCAGCTAGCATGGAAAAGAATTGTCGTGGAGTGAGAAAAGGTACTTGGACCAAAGAAGAAGACA CTCTCTTGAGGCAATGTATAGAAGAGTATGGTGAAGGGAAATGGCATCAAGTTCCACACAGAGCAGGGTTGAACCGGTGTAGGAAGAGTTGCAGGCI GAGGTGGTTGAATTATCTGAGGCCAAATATCAAAAGAGGTCGGTTTTCGAGAGATGAAGTGGACCTAATTGTGAGGCTTCATAAGCTGTTGGGTAAC AAATGGTCGCTGATTGCTGGTAGAATTCCTGGAAGGACAGCTAATGACGTGAAGAACTTTTGGAATACTCATGTGGGGAAGAATTTAGGCGAGGATC GAGAACGATGCCGGAAAAATGTTATGAACACAAAAACCATTAAGCTGACTAATATCGTAAGACCCCGAGCTCGGACCTTCACCGGATTGCACGTTAC TTGGCCGAGA GAA GTCGGAAAAACCGATGAATTTTCAAAT GTCCGGTTAACAACTGATGAGATTCCAGATTGTGAGAAGCAAACGCAATTTTACAA' GATGTTGCGTCGCCACAAGATGAAGTTGAAGACTGCATTCAGTGGTGGAGTAAGTTGCTAGAAACAACGGAGGATGGGGAATTAGGAAACCTATTCG AGGAGGCCCAACAAATTGGAAATTAACGCCGATAAGCTTGATAGGGCCATTGCCGATCTCAAGCCACTCTCCGTTGAACGGTTAAGTTTCCATTGAT ACTCGAAAGATGTCAGCACCAGCTAGCACAACACAGCCCATAGGGTCAACTACCTCAACTACCACAAAAACTGCAGGCGCAACTCCTGCCACAGCTT CAGGCCTGTTCACCATCCCGGATGGGGATTTCTTTAGTACAGCCCGTGCCATAGTAGCCAGCAATGCTGTCGCAACAAATGAGGACCTCAGCAAGAT TGAGGCTATTTGGAAGGACATGAAGGTGCCCACAGACACTATGGCACAGGCTGCTTGGGACTTAGTCAGACACTGTGCTGATGTAGGATCATCCGC T CAAACAGAAATGATAGATACAGGTCCCTATTCCAACGGCATCAGCAGAGCTAGACTGGCAGCAGCAATTAAAGAGGTGTGCACACTTAGGCAATTTT 


\section{RESULTADOS}

GCATGAAGTATGCTCCAGTGGTATGGAACTGGATGTTAACTAACAACAGTCCACCTGCTAACTGGCAAGCACAAGGTTTCAAGCCTGAGCACAAATT CGCTGCATTCGACTTCTTCAATGGAGTCACCAACCCAGCTGCCATCATGCCCAAAGAGGGGCTCATCCGGCCACCGTCTGAAGCTGAAATGAATGCT GCCCAAACTGCTGCCTTTGTGAAGATTACAAAGGCCAGGGCACAATCCAACGACTTTGCCAGCCTAGATGCAGCTGTCACTCGAGGTCGTATCACTG GAACAACAACCGCTGAGGCTGTTGTCACTCTACCACCACCATAACTACGTCTACATAACCGACGCCTACCCCAGTTTCATAGTATTTTCTGGTTTGA TTGTATGAATAATATAAATAAAAAAAAAAAAAAAAAAAAAAAAAAAAAAAAAAAAAAAAAAAAAAAAAAAAAAAAAAAAAAAAAAAAAAAAAAAAAA AAAAAAAA

\section{$>$ TRV2-Ros1}

ATAAAACATTGCACCTATGGTGTTGCCCTGGCTGGGGTATGTCAGTGATCGCAGTAGAATGTACTAATTGACAAGTTGGAGAATACGGTAGAACGTC CTTATCCAACACAGCCTTTATCCCTCTCCCTGACGAGGTTTTTGTCAGTGTAATATTTCTTTTTGAACTATCCAGCTTAGTACCGTACGGGAAAGTG ACTGGTGTGCTTATCTTTGAAATGTTACTTTGGGTTTCGGTTCTTTAGGTTAGTAAGAAAGCACTTGTCTTCTCATACAAAGGAAAACCTGAGACGT ATCGCTTACGAAAGTAGCAATGAAAGAAAGGTGGTGGTTTTAATCGCTACCGCAAAAACGATGGGGTCGTTTTAATTAACTTCTCCTACGCAAGCGT CTAAACGGACGTTGGGGTTTTGCTAGTTTCTTTAGAGAAAACTAGCTAAGTCTTTAATGTTATCATTAGAGATGGCATAAATATAATACTTGTGTCT GCTGATAAGATCATTTTAATTTGGACGATTAGACTTGTTGAACTACAGGTTACTGAATCACTTGCGCTAATCAACATGGGAGATATGTACGATGAAT CATTTGACAAGTCGGGCGGTCCTGCTGACTTGATGGACGATTCTTGGGTGGAATCAGTTTCGTGGAAAGATCTGTTGAAGAAGTTACACAGCATAAA ATTTGCACTACAGTCTGGTAGAGATGAGATCACTGGGTTACTAGCGGCACTGAATAGACAGTGTCCTTATTCACCATATGAGCAGTTTCCAGATAAG AAGGTGTATTTCCTTTTAGACTCACGGGCTAACAGTGCTCTTGGTGTGATTCAGAACGCTTCAGCGTTCAAGAGACGAGCTGATGAGAAGAATGCAG TGGCGGGTGTTACAAATATTCCTGCGAATCCAAACACAACGGTTACGACGAACCAAGGGAGTACTACTACTACCAAGGCGAACACTGGCTCGACTTT GGAAGAAGACTTGTACACTTATTACAAATTCGATGATGCCTCTACAGCTTTCCACAAATCTCTAACTTCGTTAGAGAACATGGAGTTGAAGAGTTAT TACCGAAGGAACTTTGAGAAAGTATTCGGGATTAAGTTTGGTGGAGCAGCTGCTAGTTCATCTGCACCGCCTCCAGCGAGTGGAGGTCCGATACGTC CTAATCCCTAGGGATTTAAGGACGTGAACTCTGTTGAGATCTCTGTGAAATTCAGAGGGTGGGTGATACCATATTCACTGATGCCATTAGCGACATC TAAATAGGGCTAATTGTGACTAATTTGAGGGAATTTCCTTTACCATTGACGTCAGTGTCGTTGGTAGCATTTGAGTTTCGCAATGCACGAATTACTT AGGAAGTGGCTTGACGACACTAATGTGTTATTGTTAGATAATGGTTTGGTGGTCAAGGTACGTAGTAGAGTCCCACATATTCGCACGTATGAAGTAA TTGGAAAGTTGTCAGTTTTTGATAATTCACTGGGAGATGATACGCTGTTTGAGGGAAAAGTAGAGAACGTATTTGTTTTTATGTTCAGGCGGTTCTT GTGTGTCAACAAAGATGGACATTGTTACTCAAGGAAGCACGATGAGCTTTATTATTACGGACGAGTGGACTTAGATTCTGTGAGTAAGGTTACCGAA TTATGGAAAA GAATTGTCGTGGA GT GAGAAAAGGTACTTGGACCAAAGAAGAAGACACTCTCTTGAGGCAATGTATAGAAGAGTATGGTGAAGGGAA ATGGCATCAAGTTCCACACAGAGCAGGGTTGAACCGGTGTAGGAAGAGTTGCAGGCTGAGGTGGTTGAATTATCTGAGGCCAAATATCAAAAGAGGT CGGTTTTCGAGAGATGAAGTGGACCTATTGTGAGGCTTCATAAGCTGTTGGGTAACAAATGGTCGCTGATTGCTGGTAGAATTCCTGGAAGGACAG СTAATGACGTGAAGAACTTTTGGAATACTCATGTGGGGAAGAATTTAGGCGAGGATGGAGAACGATGCCGGAAAAATGTTATGAACACAAAAACCAT TAAGCTGACTAATATCGTAAGACCCCGAGCTCGGACCTTCACCGGATTGCACGTTACTTGGCCGAGAGAAGTCGGAAAAACCGATGAATTTTCAAAT GTCCGGTTAACAACTGATGAGATTCCAGATTGTGAGAAGCAAACGCAATTTTACAATGATGTTGCGTCGCCACAAGATGAAGTTGAAGACTGCATTC AGTGGTGGAGTAAGTTGCTAGAAACAACGGAGGATGGGGAATTAGGAAACCTATTCGAGGAGGCCCAACAAATTGGAAATTAACTCGAGGCCCGGGC ATGTCCCGAAGACATTAAACTACGGTTCTTTAAGTAGATCCGTGTCTGAAGTTTTAGGTTCAATTTAAACCTACGAGATTGACATTCTCGACTGATC TTGATTGATCGGTAAGTCTTTTGTAATTTAATTTTCTTTTTGATTTTATTTTAAATTGTTATCTGTTTCTGTGTATAGACTGTTTGAGATCGGCGTT TGGCCGACTCATTGTCTTACCATAGGGGAACGGACTTTGTTTGTGTTGTTATTTTATTTGTATTTTATTAAAATTCTCAACGATCTGAAAAAGCCTC GCGGCTAAGAGATTGTTGGGGGGTGAGTAAGTACTTTTAAAGTGATGATGGTTACAAAGGCAAAAGGGGTAAAACCCCTCGCCTACGTAAGCGTTAT TACGCCC 
CAPÍTULO 8:

DISCUSIÓN GENERAL 
Desde su descripción los virus de plantas han siedo empleados como modelos para el estudio de variados aspectos de la biología en general, y de los mecanismos moleculares de interacción y regulación de genes entre los patógenos y sus huéspedes. Asímismo, gracias al amplio conocimiento que se ha alcanzado y se continúa extendiendo sobre estos agentes infecciosos, ha sido posible su aplicación en el desarrollo de variadas herramientas moleculares, como por ejemplo construcción de vectores para estudios de VIGS (Lu et al., 2003) o para la expresión de proteínas heterólogas en plantas (Porta y Lomonossoff, 2002; Gleba et al., 2007; Lico et al., 2008). Sin embargo, debido a su naturaleza y a la imposibilidad de cultivarlos como se hace con microorganismos como bacterias y hongos, para poder estudiarlos y modificarlos es necesario contar con elementos que faciliten su uso in vitro y su manipulación a nivel genético y molecular. Ya que la gran mayoría de virus vegetales poseen un genoma de RNA, el progreso de las técnicas necesarias para obtener copias de DNA de dichos genomas (Dawson et al., 1986) y clonarlos en sistemas como plásmidos bacterianos ha sido determinante para el avance en la investigación que se realiza sobre ellos desde hace décadas. Dicha facilidad para obtener clones infecciosos de virus de plantas ha permitido que actualmente existan clones de cDNA para un sinnúmero de virus, los cuales permiten una infección relativamente fácil y rápida de plantas y la posibilidad de modificar genéticamente sus genomas para diferentes tipos de estudios. En el caso del virus del grabado del tabaco (TEV), el plásmido pTEV7DA (Carrington et al., 1993; Dolja et al., 1993) es el más ampliamente usado hasta ahora. Permite realizar la transcripción in vitro y obtener RNAs infecciosos con los que inocular plantas. Aunque con este clon se han llevado a cabo un gran número de estudios sobre potyvirus y sobre el TEV, presenta problemas de estabilidad cuando se propaga en Escherichia coli como mutaciones y deleciones parciales o totales en el cDNA viral o del plásmido que lo contiene (Capítulo 3, Fig. 1B). Adicionalmente, la infección con RNA no siempre es tan eficiente como se desea y representa un proceso relativamente complejo en comparación con otros métodos que se han desarrollado como la agroinoculación (Grimsley et al., 1986).

En este trabajo se construyeron tres nuevos clones infecciosos del TEV con el fin de mejorar su estabilidad en bacterias y ofrecer la posibilidad de inocular plantas con DNA, con RNA o por agroinfección. Habitualmente, las estrategias para mejorar la estabilidad de los clones virales en bacterias se basan en modificar de alguna manera la propia 
secuencia viral. Por ejemplo, se pueden introducir intrones para interrumpir genes potencialmente tóxicos para E. coli (Johansen, 1996), o realizar mutaciones que impidan la expresión de los mismos (Satyanarayana et al., 2003). Sin embargo, en este caso se optó por manipular las secuencias exógenas al genoma viral dentro del vector plasmídico, intentando conservar solamente aquellos elementos necesarios para su correcta replicación y mantenimiento en las bacterias, como el origen de replicación o genes de resistencia a antibióticos. Los resultados obtenidos sugieren que, aunque usualmente la inestabilidad de los clones virales en bacterias está relacionada con la expresión de genes virales cuyos productos resultan tóxicos para las bacterias (Boyer y Haenni, 1994), todos los componentes de los vectores y los elementos alrededor de la propia secuencia viral pueden tener un papel relevante. Es así como se vio un aumento significativo de la estabilidad con respecto al plásmido original al eliminar la porción de las secuencias que se pueden considerar prescindibles o innecesarias e insertar en dirección contraria al marcador de selección y origen de replicación el clon del TEV contenido en el plásmido pTEV7DA. De este modo, los nuevos plásmidos se encuentran en un vector mínimo y con un casete compuesto únicamente por el promotor y terminador correspondientes, el origen de replicación mínimo y el marcador de selección adecuado. En el estudio de pases en cultivo líquido cada 24 horas realizado con diferentes linajes bacterianos, los tres plásmidos construidos, pMTEV, p35TEV y pGTEV tuvieron una mayor estabilidad que pTEV7DA, ya que en ningún caso se presentaron las extensas y variadas deleciones observadas en este último (Capítulo 3, Fig. 1). pMTEV representa el mejor ejemplo de cómo las dos sencillas modificaciones descritas pueden llevar a mejorar la estabilidad de un clon viral, ya que aunque este plásmido al igual que pTEV7DA se usa para realizar la transcripción in vitro y obtener RNA infeccioso, y es básicamente igual a su predecesor solo que con una diferencia de tamaño de alrededor de $1 \mathrm{kpb}$ y una orientación del genoma del TEV opuesta a los demás elementos del vector, no presentó cambios durante todos los pases. El plásmido p35TEV se diferencia de pMTEV en que posee el promotor y el terminador del 35S del CaMV, lo cual resultó en la posible generación de rearreglos o duplicaciones que produjeron plásmidos de mayor tamaño que el original en el estudio de pases (Capítulo 3, Fig. 1D), sugiriendo alguna actividad del promotor 35S en bacterias, como se ha descrito en otros casos (Assaad y Signer, 1990). En el plásmido pGTEV construido para realizar agroinoculación, sin embargo, al situar exactamente el mismo casete de p35TEV entre los bordes derecho e izquierdo del T-DNA de 
Agrobacterium tumefaciens, la estabilidad fue casi tan alta como la de pMTEV, excepto por uno de los 10 linajes establecidos para el que se produjo un plásmido más grande que el original (Capítulo 3, Fig. 1E). Adicionalmente, al hacer un estudio práctico sobre los tres tipos de inóculos obtenidos a partir de los 3 nuevos plásmidos se notó que la agroinoculación con el plásmido pGTEV, como ha ocurrido para muchos otros virus (Vaghchhipawala y Mysore, 2008), fue un método altamente eficiente para la infección fácil y rápida de plantas de tabaco.

Gracias al avance conseguido en la estabilidad del clon infeccioso del TEV, y partiendo del plásmido pGTEV, se desarrolló un vector para expresar simultáneamente varias proteínas heterólogas en plantas. Para ello, el gen de la polimerasa viral Nlb se sustituyó por un casete correspondiente a tres proteínas reporteras fluorescentes distintas, separadas entre sí por sitios artificiales de procesamiento de la proteasa viral NlaPro (Capítulo 4, Fig. 1). Para suplementar la función de Nlb se emplearon, por un lado, plantas transgénicas que contienen el gen de la proteína viral $y$, por otro, la coinoculación con un vector basado en el virus $\mathrm{X}$ de la patata (Potato virus $X, \mathrm{PVX}$ ) que expresa el mismo gen a través de un promotor duplicado. Al inocular plantas de tabaco transgénicas o de Nicotiana benthamiana, respectivamente, el vector con las tres proteínas fue capaz de provocar síntomas e infectar sistémicamente únicamente en el primer caso, comprobando la capacidad de dichas plantas de suplementar la actividad de Nlb descrita con anterioridad (Li y Carrington, 1995). Además, la infección con el vector TEVANIb-CVB en estas plantas tardó un poco más en desarrollarse, en comparación con el TEV silvestre, y los síntomas que se desarrollaron fueron levemente más tenues, hecho que también se ha observado al insertar material genético exógeno en otros virus (German-Retana et al., 2000).

El análisis de la expresión por microscopía en tejido sintomático mostró una correcta fluorescencia de las proteínas azul, amarilla (verde con el filtro empleado) y roja a nivel celular y subcelular, comprobándose la expresión simultánea de las tres proteínas y su colocalización en las células vegetales (Capítulo 4, Fig. 2A). La estrategia de expresión de los potyvirus por medio de una poliproteína, procesada postraduccionalmente, es uno de sus atractivos para usarse como vectores, ya que al expresarse todas las proteínas en una misma localización, y en cantidades equimolares, potencialmente se podrían expresar complejos proteicos, componentes de rutas metabólicas y proteínas 
heterooligoméricas como anticuerpos, para ensamblarse y funcionar de forma más eficiente y coordinada que con otras estrategias empleadas hasta ahora (Giritch et al., 2006).

Por otro lado, en tejido infectado se analizó el procesamiento de cada proteína reportera a partir de la poliproteína viral (Capítulo 4, Fig. 3). Debido a que se ha descrito que la proteasa NlaPro de los potyvirus es la encargada del procesamiento de la mayoría de las proteínas virales (Merits et al., 2002), en el vector basado en el TEV se introdujeron sitios de procesamiento de dicha proteasa entre las tres distintas proteínas fluorescentes reporteras. Al igual que lo observado por Carrington et al. (1993), se vio que dichos sitios de procesamiento permiten que proteínas introducidas dentro de la poliproteína viral, en este caso las proteínas mCherry, Venus y mTagBFP, se liberen correcta y eficientemente de la poliproteína y funcionen como proteínas individuales en las células vegetales.

En lo referente a los niveles de expresión de proteínas por medio de este vector, un análisis cuantitativo de la proteína mCherry (Capítulo 4, Fig. 5) mostró que, transcurridos 9 días de la inoculación de plantas de tabaco transgénicas, esta proteína se acumula en aproximadamente $8 \mathrm{mg}$ por $\mathrm{kg}$ de tejido fresco mientras que con el control simple (que contiene únicamente mCherry) se pueden acumular hasta casi 20 mg por $\mathrm{kg}$ de tejido. Dichas concentraciones son comparables a la expresión observada en estudios con vectores basados en otros potyvirus (Masuta et al., 2000; Hsu et al., 2004), aunque estas concentraciones de proteína están netamente por debajo de las obtenidas con otros tipos de vectores de expresión más ampliamente empleados, como los basados en el virus del mosaico del tabaco (Tobacco mosaic virus, TMV) que permiten obtener hasta un 5\% de proteína del total de proteínas solubles (Lindbo, 2007). Sin embargo, al emplear el vector del TEV defectivo para expresar los factores de transcripción Delila y Rosea1 de Antirrhinum majus, que conjuntamente promueven la biosíntesis de antocianinas, se pudo observar en hojas sintomáticas una coloración típica consecuencia de la acumulación de estas sustancias (Capítulo 4, Fig. 7), hecho que sugiere que, aún en cantidades relativamente bajas, por medio de este vector es posible expresar diversas proteínas funcionalmente activas y en un mismo sitio, lo cual puede ser suficiente para determinados objetivos. 
La construcción de vectores de expresión basados en potyvirus se ha hecho introduciendo el gen de interés principalmente entre el cistrón de la proteína $\mathrm{P} 1$ y el de HC-Pro (Dolja et al., 1992; Guo et al., 1998; Masuta et al., 2000), o entre los genes de las proteínas NIb y CP (Shiboleth et al., 2001; Dietrich y Maiss, 2003), aunque también se han probado otros posibles sitios de inserción (Chen et al., 2007). En el vector desarrollado aquí, se optó por el segundo sitio de inserción, con la diferencia de introducir un solo casete de expresión conteniendo las proteínas de interés en reemplazo del cistrón de la NIb, quedando flanqueado por NlaPro y CP. Dicha estrategia permitió expresar correctamente todas las proteínas ensayadas, corroborando la facilidad de expresar genes por medio del TEV, así como ha sucedido con otros potyvirus (Beauchemin et al., 2005). Masuta et al. (2000) lograron expresar simultáneamente las proteínas GFP y glutamina sintetasa de la soja (GS), introduciéndolas conjuntamente entre P1 y HC-Pro, mientras que Beauchemin et al. (2005) probaron distintas combinaciones entre los dos sitios de inserción mencionados para expresar correctamente GFP y GUS. Asímismo, como muesta el estudio realizado en 2008 por Kelloniemi et al., el modo de ensamblaje de los viriones de los potyvirus es lo suficientemente flexible para permitir la inserción estable de hasta tres genes de proteínas heterólogas, sin perjudicar su capacidad de moverse e infectar sistémicamente las plantas. En este caso, además, la deleción de Nlb (de casi 1,5 kb) confiere una doble ventaja, ya que en teoría se podría insertar una mayor cantidad de material genético, y hace de este un sistema de expresión contenido sin riesgo de escapes al medio ambiente del virus.

Debido a los buenos resultados obtenidos con el vector de expresión defectivo basado en el TEV, se propusieron dos distintas estrategias para intentar mejorarlo. En primer lugar, y buscando aumentar los niveles de expresión de las proteínas recombinantes, se estudió el efecto de insertar junto con el gen de interés distintos supresores virales del silenciamiento. Adicionalmente al supresor natural del TEV, la proteína HC-Pro, en el vector TEV $\triangle$ NIb-mCherry se insertaron individualmente, y tras el cistrón de la proteína fluorescente separados por un sitio de procesamiento de NlaPro, los supresores 2b del CMV, 16K del TRV, P19 del TBSV y HC-Pro del PPV. La proteína HC-Pro del TEV fue el primer supresor del silenciamiento descrito, descubierta gracias a su capacidad de impedir el silenciamiento en infecciones con otros virus y de aumentar su título, en un proceso de sinergismo (Anandalakshmi et al., 1998; 
Kasschau y Carrington, 1998). Ha sido ampliamente estudiada y se han sugerido distintos mecanismos de acción, aunque es generalmente aceptado que opera uniendo pequeños RNAs (siRNAs) impidiendo así que se establezca y amplifique la señal del silenciamiento en la planta por la acción del complejo RISC (Lakatos et al., 2006). Aunque la HC-Pro del TEV es una proteína supresora altamente eficiente, se han descrito supresores de otros virus que pueden interferir en variados momentos del proceso de silenciamiento, por lo que se estudió la posibilidad de que añadir un segundo supresor al vector de expresión aumentara la capacidad supresora y esto conllevara a una mayor expresión de la proteína mCherry. Al agroinocular plantas de tabaco transgénicas (que expresan NIb) con los cuatro diferentes vectores construidos (Fig. 5.1), y el control sin ningún supresor adicional, y medir la fluorescencia de mCherry en tejido sintomático se observó que únicamente las proteínas P19 y 2b provocan un aumento de su expresión (Fig. 5.3). Este efecto fue leve para 2b, mientras que con P19 hubo un mayor aumento de la fluorescencia con respecto al control. Se ha postulado que la proteína P19 interfiere en la ruta de silenciamiento uniendo en general pequeños RNAs de doble cadena (ds-siRNAs) y, específicamente, ds-siRNAs de $21 \mathrm{nt}$ de longitud con 2 nt sobresalientes en 3' impidiendo su interacción con los componentes del complejo de silenciamiento (Lakatos et al., 2004). Además de haber sido ampliamente estudiada por su fuerte actividad supresora, se ha descrito la utilidad de emplear la proteína P19 del TBSV u otros tombusvirus en sistemas de expresión transitoria para aumentar la eficiencia de expresión de diversas proteínas (Voinnet et al., 2003), incluyendo el antígeno Nef del HIV-1 (Lombardi et al., 2009) o anticuerpos de tipo IgG (Boivin et al., 2010). P19 tiene un gran potencial a nivel biotecnológico en sistemas de expresión de proteínas, incluso en conjunción con otros supresores como HC-Pro, ya que al parecer complementan su actividad supresora. En el caso de la proteína $2 \mathrm{~b}$ del CMV, ésta provocó un leve aumento de la expresión de mCherry. Este supresor actúa, entre otras cosas, uniendo dsRNAs e interfiriendo con la actividad de corte de la proteína ARGONAUTA1 (Zhang et al., 2006). A pesar del sutil efecto de este supresor en la expresión de mCherry, su actividad puede complementar la acción de otro supresor y su potencial aplicación en la mejora de sistemas de expresión de proteínas debe ser estudiado. De forma opuesta, al insertar en el vector las proteínas HC-Pro del PPV y $16 \mathrm{~K}$ del TRV no se produjo ningún efecto en la expresión de mCherry (Fig. 5.3). De hecho, con HC-Pro se produjo una leve reducción en el nivel de fluorescencia, aunque no estadísticamente significativa, sugiriendo que este segundo 
supresor podría interferir de alguna forma con el correcto funcionamiento de la proteína HC-Pro propia del TEV. En el caso de la proteína 16K, los resultados concuerdan con la proposición de que este es un supresor relativamente débil que funciona en los primeros pasos del proceso de silenciamiento (Martínez-Priego et al., 2008), pero cuya actividad no supera la de HC-Pro para permitir la infección del vector empleado aquí y la expresión de mCherry.

La segunda estrategia estudiada para intentar mejorar el vector de expresión basado en el TEV se basó en su deconstrucción progresiva para analizar, por medio de un sistema de expresión transitoria con Agrobacterium tumefaciens en plantas de $N$. benthamiana, la capacidad de suplementar en trans los genes delecionados por medio de un vector complementario en el que las secuencias a expresar están flanqueadas por las 5' y 3' UTRs del virus del mosaico del chícharo (Cowpea mosaic virus, CPMV). Para analizar la expresión transitoria se utilizó como gen reportero Ros1, que promueve la acumulación de antocianinas en el tejido inoculado, y permite una valoración cuantitativa de dicha expresión. Como control se usó el vector pTEV $\Delta$ NIb-Ros1, a partir del cual se desarrollaron 5 nuevos vectores defectivos en los que se hizo una deleción progresiva de los cistrones en la región aminoterminal o la mayor parte de la proteína de cubierta (Fig. 6.1). Con dicho control se realizó también un análisis previo para estandarizar las condiciones del ensayo y determinar la mejor concentración (densidad óptica, DO) a la que se debía realizar la coinoculación y el tipo de tejido más adecuado para observar los resultados (Fig. 6.2). En conjunto, los resultados muestran que, además de NIb, es posible eliminar otros cistrones del TEV y suplementarlos por medio de la coinoculación de un vector que exprese dichas proteínas (Fig 6.3). El caso más notable es la correcta expresión de Ros1, y consecuente acumulación de antocianinas, del vector en el que se han delecionado también las proteínas virales P1 y HC-Pro. Estos resultados, además, revelan la posibilidad de eliminar genes del genoma viral para ampliar la capacidad del vector de insertar genes foráneos y así, en teoría, poder expresar proteínas heterólogas más grandes o en mayor número. De hecho, este sistema de expresión transitoria se basa en las valiosas características que posee Agrobacterium tumefaciens, demostradas en estudios como, por ejemplo, el de Marillonnet et al. (2004) para el ensamblaje in vivo de módulos virales dentro de células vegetales. Además, este sistema de expresión presenta una alternativa con un alto potencial de aplicación en biotecnología, ya que en general los sistemas de 
transcomplementación de funciones virales se han basado en plantas transgénicas (Holt y Beachy, 1991; Li y Carrington, 1995) u otros virus (Briddon y Markham, 2001; Latham y Wilson, 2008; Hiraguri et al., 2011).

Con todo, se puede decir que el vector de expresión defectivo basado en el TEV desarrollado en este estudio es una herramienta adecuada para la expresión de proteínas heterólogas y, además, con un alto potencial de aplicación en otros tipos de estudios tanto básicos como aplicados. La capacidad de implementar metodologías para mejorar su capacidad de expresión, insertando los supresores del silenciamiento P19 o 2b, y delecionando cistrones virales como P1/HC-Pro para suplementarlos en trans, aumenta las posibilidades de emplearlo en el futuro en ingeniería metabólica de plantas o para expresar proteínas de interés farmacéutico o industrial.

En lo referente a los factores de transcripción Delila y Rosea1 de Antirrhinum majus, se planteó la posibilidad de utilizarlos como marcadores visuales para el seguimiento de infecciones y movimiento de virus de plantas como el TEV. Dichos genes forman parte de los reguladores dentro de la ruta de biosíntesis de antocianinas en las flores de $A$. majus, e interactúan para promover la activación de muchos de los genes que codifican las enzimas que la componen (Schwinn et al., 2006). La capacidad de estos factores de transcripción de producir antocianinas se ha aprovechado con fines aplicados, por ejemplo, para aumentar el contenido de estos antioxidantes en frutos de tomate y hacerlos más beneficiosos para la dieta humana (Butelli et al., 2008), o para emplearlos en estudios de silenciamiento génico mediado por virus (VIGS) (Orzaez et al., 2009). Sin embargo, Delila y Rosea 1 juntos representan un inserto de gran tamaño, siendo Delila el más grande (aproximadamente $2 \mathrm{kpb}$ ) y, además, las observaciones del presente trabajo mostraron que unidos promueven una acumulación de antocianinas que puede llegar a influir negativamente en el buen estado de las plantas inoculadas. Por este motivo, se optó por estudiar únicamente la utilidad de la región codificante del gen Rosea1 (Ros1), con un tamaño de 660 pb, como marcador. Al insertar dicho gen en dos diferentes posiciones dentro del genoma del TEV, y agroinocular plantas de tabaco, se pudo observar la acumulación de antocianinas en las zonas donde se desarrollan los síntomas típicos del TEV consecuencia de la infección sistémica del virus. Este hecho permitió analizar el proceso de infección viral tanto a nivel de una sola hoja como en toda la planta a lo largo del tiempo, comprobándose también que 
este marcador no afecta el desarrollo de la infección viral (Capítulo 7, Fig. 1). En comparación con los genes reporteros empleados al estudiar virus de vegetales, comúnmente proteínas fluorescentes como la GFP (Baulcombe et al., 1995; Tsien, 1998) o iLOV (Chapman et al., 2008) y enzimas como GUS (Hull y Devic, 1995), la expresión de Ros1 no tiene un efecto visual inmediato, sino que su acción sobre la ruta de biosíntesis de antocianinas puede estar levemente retrasada con respecto a la aparición de síntomas y movimiento del virus a lo largo de la planta. Sin embargo, las antocianinas, consecuencia de la presencia de este marcador, se localizan únicamente donde se encuentra el virus (Capítulo 7, Fig. 3) y en las mismas zonas donde se puede observar la expresión de la GFP dentro de la planta (Capítulo 7, Fig. 2B), mostrando su utilidad para monitorear la infección viral. Ros1 también es un marcador altamente estable que permanece funcional durante varios pases sucesivos del virus de planta a planta (Capítulo 7, Fig. 5), lo que lo hace conveniente para otros tipos de estudios en virología, como los enfocados a evolución (De la Iglesia y Elena, 2007). Además, el uso de Ros1 como gen reportero o marcador tiene la ventaja de no requerir ningún instrumento de microscopía o técnica bioquímica destructiva para su visualización, como es el caso de otros biomarcadores, haciéndolo atractivo para análisis masivos de plantas rápidos y sencillos. De igual forma, al examinar la relación entre la acumulación de antocianinas y de partículas virales, se encontró que Ros1 también puede usarse en análisis cuantitativos, ya que la cantidad de antocianinas presentes en tejido sintomático está correlacionada positivamente con la concentración del virus (Capítulo 7, Fig. 4). Finalmente, se vio que este marcador es útil para estudiar otros tipos de virus distintos al TEV, y que infectan a otras plantas como Arabidopsis thaliana o Nicotiana benthamiana, como por ejemplo el potyvirus del mosaico del nabo (Turnip mosaic virus, TuMV), el tobamovirus del mosaico del tabaco (TMV) y el potexvirus de la patata (Potato virus $X, \mathrm{PVX}$ ). Sin embargo, hay que tener en cuenta que la respuesta de este marcador reportero dependerá de cada combinación virus-planta. 
CONCLUSIONES 
- Es posible estabilizar clones infecciosos del virus del grabado del tabaco (TEV), sin alterar el propio clon viral, eliminando secuencias superfluas del vector en el que se insertan y situando todos los demás elementos funcionales de manera que se minimice la posible expresión de secuencias que puedan resultar tóxicas para las bacterias donde se propaga el plásmido.

- De los nuevos plásmidos construidos conteniendo el mismo clon infeccioso del TEV, el empleado para la agroinoculación (pGTEV) resultó ser el más sencillo de usar desde un punto de vista práctico para infectar un gran número de plantas en un tiempo mínimo.

- El clon infectivo del TEV pudo emplearse como vector de expresión de múltiples proteínas heterólogas, sustituyendo el gen de la polimerasa viral NIb por los de tres proteínas fluorescentes reporteras, observándose su expresión simultánea en el tejido vegetal infectado.

- De los dos sistemas de suplementación en trans de la proteína Nlb estudiados, el empleo de plantas transgénicas que expresan constitutivamente este gen o la coinoculación con el vector PVX-Nlb, el primerodemostró ser el más eficiente y que permite una correcta infección y movimiento sistémico del virus vector de expresión, añadiendo así una ventaja en bioseguridad y contención al sistema.

- La inserción de sitios de procesamiento artificiales reconocidos por la proteasa viral NlaPro para separar las distintas proteínas heterólogas en los casetes de expresión, demostró ser una estrategia adecuada para permitir el correcto procesamiento de las proteínas a partir de la poliproteína viral y su acumulación en forma madura.

- Además de genes reporteros, fue posible expresar los factores de transcripción Delila y Rosea1 de Antihrrinum majus, que interaccionan para promover la biosíntesis de antocianinas en plantas, mostrando la potencialidad del vector en ingeniería metabólica de plantas. 
- La adición al vector de expresión del supresor del silenciamiento viral P19 (del virus del enanismo arbustivo del tomate, TBSV) y, en menor medida, de $2 b$ (del virus del mosaico del pepino, CMV), puede mejorar la expresión de proteínas heterólogas.

- Un ensayo de expresión transitoria mostró que es posible delecionar del vector de expresión, además de NIb, los cistrones de P1/HC-Pro para suplementar su actividad en trans y así aumentar potencialmente la cantidad de información heteróloga que se puede expresar.

- El factor de transcripción Rosea1 de A. majus puede emplearse eficientemente como marcador visual para estudiar la dinámica de infección viral en plantas. Este marcador es, además, cuantitativo y estable en el genoma viral durante el proceso infectivo. 
BIBLIOGRAFÍA 
Ahlquist, P., French, R., Janda, M., and Loesch-Fries, L. S. (1984). Multicomponent RNA plant virus infection derived from cloned viral cDNA. Proc Natl Acad Sci $U S A$ 81(22), 7066-70.

Ai, H. W., Henderson, J. N., Remington, S. J., and Campbell, R. E. (2006). Directed evolution of a monomeric, bright and photostable version of Clavularia cyan fluorescent protein: structural characterization and applications in fluorescence imaging. Biochem $J$ 400(3), 531-40.

Ala-Poikela, M., Goytia, E., Haikonen, T., Rajamaki, M. L., and Valkonen, J. P. (2011). Helper component proteinase of the genus Potyvirus is an interaction partner of translation initiation factors elF(iso)4E and elF4E and contains a 4E binding motif. $J$ Virol 85(13), 6784-94.

Almazán, F., González, J. M., Penzes, Z., Izeta, A., Calvo, E., Plana-Duran, J., and Enjuanes, L. (2000). Engineering the largest RNA virus genome as an infectious bacterial artificial chromosome. Proc Natl Acad Sci U S A 97(10), 5516-21.

Álvarez, M. L., Pinyerd, H. L., Topal, E., and Cardineau, G. A. (2008). P19-dependent and P19-independent reversion of $\mathrm{F} 1-\mathrm{V}$ gene silencing in tomato. Plant $\mathrm{Mol} \mathrm{Biol}$ 68(12), 61-79.

Anandalakshmi, R., Pruss, G. J., Ge, X., Marathe, R., Mallory, A. C., Smith, T. H., and Vance, V. B. (1998). A viral suppressor of gene silencing in plants. Proc Natl Acad Sci U $S$ A 95(22), 13079-84.

Antonucci, T. K., Wen, P., and Rutter, W. J. (1989). Eukaryotic promoters drive gene expression in Escherichia coli. J Biol Chem 264(30), 17656-9.

Arazi, T., Shiboleth, Y. M., and Gal-On, A. (2001a). A nonviral peptide can replace the entire $\mathrm{N}$ terminus of zucchini yellow mosaic potyvirus coat protein and permits viral systemic infection. J Virol 75(14), 6329-36.

Arazi, T., Slutsky, S. G., Shiboleth, Y. M., Wang, Y., Rubinstein, M., Barak, S., Yang, J., and Gal-On, A. (2001b). Engineering zucchini yellow mosaic potyvirus as a nonpathogenic vector for expression of heterologous proteins in cucurbits. J Biotechnol 87(1), 67-82.

Assaad, F. F., and Signer, E. R. (1990). Cauliflower mosaic virus P35S promoter activity in Escherichia coli. Mol Gen Genet 223(3), 517-20.

Bancaud, A., Huet, S., Rabut, G., and Ellenberg, J. (2010). Fluorescence perturbation techniques to study mobility and molecular dynamics of proteins in live cells: FRAP, photoactivation, photoconversion, and FLIP. Cold Spring Harb Protoc 2010(12), pdb top90.

Barta A., S. K., Thompson D., Hartmuth K., Matzke M. and Matzke A. (1986). The expression of a nopaline synthase-human growth hormone chimaeric gene in transformed tobacco and sunflower callus tissue Plant Molecular Biology 6(5), 347-357 
Basaran, P., and Rodriguez-Cerezo, E. (2008). Plant molecular farming: opportunities and challenges. Crit Rev Biotechnol 28(3), 153-72.

Baulcombe, D. C., Chapman, S., and Santa Cruz, S. (1995). Jellyfish green fluorescent protein as a reporter for virus infections. Plant $J$ 7(6), 1045-53.

Baulcombe, D. (2004). RNA silencing in plants. Nature 431(7006), 356-63.

Beauchemin, C., Bougie, V., and Laliberte, J. F. (2005). Simultaneous production of two foreign proteins from a polyvirus-based vector. Virus Res 112(1-2), 1-8.

Bedoya, L., Martínez, F., Rubio, L. and Darós, J.A. (2010). Simultaneous equimolar expression of multiple proteins in plants from a disarmed potyvirus vector. J. Biotechnol. 150(2010), 268-275.

Bisbee, C. A. (1993). Current perspectives on manufacturing and scale-up of biopharmaceuticals. Gen Eng News 13(14), 8-9.

Boivin, E. B., Lepage, E., Matton, D. P., De Crescenzo, G., and Jolicoeur, M. (2010). Transient expression of antibodies in suspension plant cell suspension cultures is enhanced when co-transformed with the tomato bushy stunt virus p19 viral suppressor of gene silencing. Biotechnol Prog 26(6), 1534-43.

Bokman, S. H., and Ward, W. W. (1981). Renaturation of Aequorea gree-fluorescent protein. Biochem Biophys Res Commun 101(4), 1372-80.

Bonnet, J., Coopman, P., and Morris, M. C. (2008). Characterization of centrosomal localization and dynamics of Cdc25C phosphatase in mitosis. Cell Cycle 7(13), 1991-8.

Bortolamiol, D., Pazhouhandeh, M., Marrocco, K., Genschik, P., and Ziegler-Graff, V. (2007). The Polerovirus $F$ box protein P0 targets ARGONAUTE1 to suppress RNA silencing. Curr Biol 17(18), 1615-21.

Boyer, J. C., and Haenni, A. L. (1994). Infectious transcripts and cDNA clones of RNA viruses. Virology 198(2), 415-26.

Bragg, J. N., and Jackson, A. O. (2004). The C-terminal region of the Barley stripe mosaic virusgammab protein participates in homologous interactions and is required for suppression of RNA silencing. Mol Plant Pathol 5(5), 465-81.

Briddon, R. W., and Markham, P. G. (2001). Complementation of bipartite begomovirus movement functions by topocuviruses and curtoviruses. Arch Virol 146(9), 1811-9.

Brisson, N., Paszkowski, J., Penswick, J.R., Gronenborn, B., Potrykus, I. and Hohn, T. (1984). Expression of a bacterial gene in plants by using a viral vector. Nature 310(5977), 511-14.

Butelli, E., Titta, L., Giorgio, M., Mock, H. P., Matros, A., Peterek, S., Schijlen, E. G., Hall, R. D., Bovy, A. G., Luo, J., and Martin, C. (2008). Enrichment of tomato fruit with health-promoting anthocyanins by expression of select transcription factors. Nat Biotechnol 26(11), 1301-8. 
Campbell, R. E., Tour, O., Palmer, A. E., Steinbach, P. A., Baird, G. S., Zacharias, D. A., and Tsien, R. Y. (2002). A monomeric red fluorescent protein. Proc Natl Acad Sci $U$ $S$ A 99(12), 7877-82.

Cañizares, M. C., Nicholson, L., and Lomonossoff, G. P. (2005). Use of viral vectors for vaccine production in plants. Immunol Cell Biol 83(3), 263-70.

Carrington, J. C., Haldeman, R., Dolja, V. V., and Restrepo-Hartwig, M. A. (1993). Internal cleavage and trans-proteolytic activities of the VPg-proteinase (NIa) of tobacco etch potyvirus in vivo. $J$ Virol 67(12), 6995-7000.

Casais, R., Thiel, V., Siddell, S. G., Cavanagh, D., and Britton, P. (2001). Reverse genetics system for the avian coronavirus infectious bronchitis virus. J Virol 75(24), 12359-69.

Chalfie, M., Tu, Y., Euskirchen, G., Ward, W. W., and Prasher, D. C. (1994). Green fluorescent protein as a marker for gene expression. Science 263(5148), 802-5.

Chalker-Scott, L. (1999). Environmental significance of anthocyanins in plant stress responses. Photochem and Photobiolog 70(1), 1-9

Chapman, S., Kavanagh, T., and Baulcombe, D. (1992). Potato virus $X$ as a vector for gene expression in plants. Plant J 2(4), 549-57.

Chapman, S., Faulkner, C., Kaiserli, E., Garcia-Mata, C., Savenkov, E. I., Roberts, A. G., Oparka, K. J., and Christie, J. M. (2008). The photoreversible fluorescent protein iLOV outperforms GFP as a reporter of plant virus infection. Proc Natl Acad Sci U S A 105(50), 20038-43.

Chen, C. C., Chen, T. C., Raja, J. A., Chang, C. A., Chen, L. W., Lin, S. S., and Yeh, S. D. (2007). Effectiveness and stability of heterologous proteins expressed in plants by Turnip mosaic virus vector at five different insertion sites. Virus Res 130(1-2), 210-27.

Chen, Y., Xu, W., and Sun, Q. (2009). A novel and simple method for high-level production of reverse transcriptase from Moloney murine leukemia virus (MMLV-RT) in Escherichia coli. Biotechnol Lett 31(7), 1051-7.

Chiera, J. M., Lindbo, J. A., and Finer, J. J. (2008). Quantification and extension of transient GFP expression by the co-introduction of a suppressor of silencing. Transgenic Res 17(6), 1143-54.

Choi, I. R., Stenger, D. C., Morris, T. J., and French, R. (2000). A plant virus vector for systemic expression of foreign genes in cereals. Plant $\mathrm{J}$ 23(4), 547-55.

Chung, B. Y., Miller, W. A., Atkins, J. F., and Firth, A. E. (2008). An overlapping essential gene in the Potyviridae. Proc Natl Acad Sci U S A 105(15), 5897-902.

Clark, A. J. (1998). The mammary gland as a bioreactor: expression, processing, and production of recombinant proteins. J Mammary Gland Biol Neoplasia 3(3), 337-50. 
Cohen, Y., Gisel, A., and Zambryski, P. C. (2000). Cell-to-cell and systemic movement of recombinant green fluorescent protein-tagged turnip crinkle viruses. Virology 273(2), $258-66$.

Cress, D. E., Kiefer, M. C., and Owens, R. A. (1983). Construction of infectious potato spindle tuber viroid cDNA clones. Nucleic Acids Res 11(19), 6821-35.

Crutzen, F., Mehrvar, M., Gilmer, D., and Bragard, C. (2009). A full-length infectious clone of beet soil-borne virus indicates the dispensability of the RNA-2 for virus survival in planta and symptom expression on Chenopodium quinoa leaves. J Gen Viro/ $90(\mathrm{Pt}$ 12), 3051-6.

Cruz, S. S., Chapman, S., Roberts, A. G., Roberts, I. M., Prior, D. A., and Oparka, K. J. (1996). Assembly and movement of a plant virus carrying a green fluorescent protein overcoat. Proc Natl Acad Sci U S A 93(13), 6286-90.

Cubitt, A. B., Woollenweber, L. A., and Heim, R. (1999). Understanding structurefunction relationships in the Aequorea victoria green fluorescent protein. Methods Cell Biol 58, 19-30.

Cui, X., Wei, T., Chowda-Reddy, R. V., Sun, G., and Wang, A. (2010). The Tobacco etch virus $\mathrm{P} 3$ protein forms mobile inclusions via the early secretory pathway and traffics along actin microfilaments. Virology 397(1), 56-63.

Daniell, H., Streatfield, S. J., and Wycoff, K. (2001). Medical molecular farming: production of antibodies, biopharmaceuticals and edible vaccines in plants. Trends Plant Sci 6(5), 219-26.

Daniell, H., Khan, M. S., and Allison, L. (2002). Milestones in chloroplast genetic engineering: an environmentally friendly era in biotechnology. Trends Plant Sci 7(2), 8491.

Daniell, H., Singh, N. D., Mason, H., and Streatfield, S. J. (2009). Plant-made vaccine antigens and biopharmaceuticals. Trends Plant Sci 14(12), 669-79.

Dawson, W. O., Beck, D. L., Knorr, D. A., and Grantham, G. L. (1986). cDNA cloning of the complete genome of tobacco mosaic virus and production of infectious transcripts. Proc Natl Acad Sci U S A 83(6), 1832-6.

De Block, M., Herrera-Estrella, L., Van Montagu, M., Schell, J., and Zambryski, P. (1984). Expression of foreign genes in regenerated plants and in their progeny. EMBO $J$ 3(8), 1681-9.

de la Iglesia, F., and Elena, S. F. (2007). Fitness declines in Tobacco etch virus upon serial bottleneck transfers. J Virol 81(10), 4941-7.

Demain, A. L., and Vaishnav, P. (2009). Production of recombinant proteins by microbes and higher organisms. Biotechnol Adv 27(3), 297-306.

Desai, P. N., Shrivastava, N., and Padh, H. (2010). Production of heterologous proteins in plants: strategies for optimal expression. Biotechnol Adv 28(4), 427-35. 
Dhillon, T., Chiera, J. M., Lindbo, J. A., and Finer, J. J. (2009). Quantitative evaluation of six different viral suppressors of silencing using image analysis of transient GFP expression. Plant Cell Rep 28(4), 639-47.

Díaz-Pendón, J. A., Li, F., Li, W. X., and Ding, S. W. (2007). Suppression of antiviral silencing by cucumber mosaic virus $2 b$ protein in Arabidopsis is associated with drastically reduced accumulation of three classes of viral small interfering RNAs. Plant Cell 19(6), 2053-63.

Dietrich, C., and Maiss, E. (2003). Fluorescent labelling reveals spatial separation of potyvirus populations in mixed infected Nicotiana benthamiana plants. J Gen Virol 84(Pt 10), 2871-6.

Dirnberger, D., Steinkellner, H., Abdennebi, L., Remy, J. J., and van de Wiel, D. (2001). Secretion of biologically active glycoforms of bovine follicle stimulating hormone in plants. Eur J Biochem 268(16), 4570-9.

Dolja, V. V., McBride, H. J., and Carrington, J. C. (1992). Tagging of plant potyvirus replication and movement by insertion of beta-glucuronidase into the viral polyprotein. Proc Natl Acad Sci U S A 89(21), 10208-12.

Dolja, V. V., Herndon, K. L., Pirone, T. P., and Carrington, J. C. (1993). Spontaneous mutagenesis of a plant potyvirus genome after insertion of a foreign gene. $J$ Virol 67(10), 5968-75.

Domier, L. L., Franklin, K. M., Hunt, A. G., Rhoads, R. E., and Shaw, J. G. (1989). Infectious in vitro transcripts from cloned cDNA of a potyvirus, tobacco vein mottling virus. Proc Natl Acad Sci U S A 86(10), 3509-13.

Domingo, E., Flavell, R. A., and Weissmann, C. (1976). In vitro site-directed mutagenesis: generation and properties of an infectious extracistronic mutant of bacteriophage Qbeta. Gene 1(1), 3-25.

Donson, J., Kearney, C. M., Hilf, M. E., and Dawson, W. O. (1991). Systemic expression of a bacterial gene by a tobacco mosaic virus-based vector. Proc Natl Acad Sci U S A 88(16), 7204-8.

Dunoyer, P., Pfeffer, S., Fritsch, C., Hemmer, O., Voinnet, O., and Richards, K. E. (2002). Identification, subcellular localization and some properties of a cysteine-rich suppressor of gene silencing encoded by peanut clump virus. Plant J 29(5), 555-67.

Dunoyer, P., and Voinnet, O. (2005). The complex interplay between plant viruses and host RNA-silencing pathways. Curr Opin Plant Biol 8(4), 415-23.

Dyck, M. K, Lacroix, D., Pothier, F., and Sirard, M. A. (2003). Making recombinant proteins in animals: different systems, different applications. Trends Biotechnol 21(9), 394-9.

Edwards, M. C., and Weiland, J. J. (2010). First infectious clone of the propagatively transmitted Oat blue dwarf virus. Arch Virol 155(4), 463-70. 
Ezure, T., Suzuki, T., Shikata, M., Ito, M., Ando, E., Utsumi, T., Nishimura, O., and Tsunasawa, S. (2010). Development of an insect cell-free system. Curr Pharm Biotechnol 11(3), 279-84.

Fauquet, C. M., and Fargette, D. (2005). International Committee on Taxonomy of Viruses and the 3,142 unassigned species. Virol $J$ 2, 64.

Fernández-Calvino, L., Goytia, E., López-Abella, D., Giner, A., Urizarna, M., Vilaplana, L., and López-Moya, J. J. (2010). The helper-component protease transmission factor of tobacco etch potyvirus binds specifically to an aphid ribosomal protein homologous to the laminin receptor precursor. J Gen Virol 91(Pt 11), 2862-73.

Fernández-Fernández, M. R., Mourino, M., Rivera, J., Rodriguez, F., Plana-Duran, J., and Garcia, J. A. (2001). Protection of rabbits against rabbit hemorrhagic disease virus by immunization with the VP60 protein expressed in plants with a potyvirus-based vector. Virology 280(2), 283-91.

Fischer, R., Vaquero-Martin, C., Sack, M., Drossard, J., Emans, N., and Commandeur, U. (1999). Towards molecular farming in the future: transient protein expression in plants. Biotechnol Appl Biochem 30 (Pt 2), 113-6.

Fischer, R., and Emans, N. (2000). Molecular farming of pharmaceutical proteins. Transgenic Res 9(4-5), 279-99.

Flavell, R. A., Sabo, D. L., Bandle, E. F., and Weissmann, C. (1975). Site-directed mutagenesis: effect of an extracistronic mutation on the in vitro propagation of bacteriophage Qbeta RNA. Proc Natl Acad Sci U S A 72(1), 367-71.

Fraley, R. T., Rogers, S. G., Horsch, R. B., Sanders, P. R., Flick, J. S., Adams, S. P., Bittner, M. L., Brand, L. A., Fink, C. L., Fry, J. S., Galluppi, G. R., Goldberg, S. B., Hoffmann, N. L., and Woo, S. C. (1983). Expression of bacterial genes in plant cells. Proc Natl Acad Sci U S A 80(15), 4803-7.

French, R., Janda, M., and Ahlquist, P. (1986). Bacterial gene inserted in an engineered RNA virus: efficient expression in monocotyledonous plant cells. Science 231(4743), 1294-7.

Fujiyama, K., Saejung, W., Yanagihara, I., Nakado, J., Misaki, R., Honda, T., Watanabe, Y., and Seki, T. (2006). In Planta production of immunogenic poliovirus peptide using tobacco mosaic virus-based vector system. J Biosci Bioeng 101(5), 398-402.

Gambin, Y., and Deniz, A. A. (2010). Multicolor single-molecule FRET to explore protein folding and binding. Mol Biosyst 6(9), 1540-7.

German-Retana, S., Candresse, T., Alias, E., Delbos, R. P., and Le Gall, O. (2000). Effects of green fluorescent protein or beta-glucuronidase tagging on the accumulation and pathogenicity of a resistance-breaking Lettuce mosaic virus isolate in susceptible and resistant lettuce cultivars. Mol Plant Microbe Interact 13(3), 316-24.

Gerngross, T. U. (2004). Advances in the production of human therapeutic proteins in yeasts and filamentous fungi. Nat Biotechnol 22(11), 1409-14. 
Ghazala, W., Waltermann, A., Pilot, R., Winter, S., and Varrelmann, M. (2008). Functional characterization and subcellular localization of the 16K cysteine-rich suppressor of gene silencing protein of tobacco rattle virus. J Gen Virol 89(Pt 7), 174858.

Giritch, A., Marillonnet, S., Engler, C., van Eldik, G., Botterman, J., Klimyuk, V., and Gleba, Y. (2006). Rapid high-yield expression of full-size IgG antibodies in plants coinfected with noncompeting viral vectors. Proc Natl Acad Sci U S A 103(40), 14701-6.

Gleba, Y., Marillonnet, S., and Klimyuk, V. (2004). Engineering viral expression vectors for plants: the 'full virus' and the 'deconstructed virus' strategies. Curr Opin Plant Biol $7(2), 182-8$.

Gleba, Y., Klimyuk, V., and Marillonnet, S. (2005). Magnifection--a new platform for expressing recombinant vaccines in plants. Vaccine 23(17-18), 2042-8.

Gleba, Y., Klimyuk, V., and Marillonnet, S. (2007). Viral vectors for the expression of proteins in plants. Curr Opin Biotechnol 18(2), 134-41.

Glick, E., Zrachya, A., Levy, Y., Mett, A., Gidoni, D., Belausov, E., Citovsky, V., and Gafni, Y. (2008). Interaction with host SGS3 is required for suppression of RNA silencing by tomato yellow leaf curl virus V2 protein. Proc Natl Acad Sci U S A 105(1), 157-61.

González, J. M., Penzes, Z., Almazan, F., Calvo, E., and Enjuanes, L. (2002). Stabilization of a full-length infectious cDNA clone of transmissible gastroenteritis coronavirus by insertion of an intron. J Virol 76(9), 4655-61.

Gopinath, K., Wellink, J., Porta, C., Taylor, K. M., Lomonossoff, G. P., and van Kammen, A. (2000). Engineering cowpea mosaic virus RNA-2 into a vector to express heterologous proteins in plants. Virology 267(2), 159-73.

Griesbeck, O., Baird, G. S., Campbell, R. E., Zacharias, D. A., and Tsien, R. Y. (2001). Reducing the environmental sensitivity of yellow fluorescent protein. Mechanism and applications. J Biol Chem 276(31), 29188-94.

Grimsley, N., Hohn, B., Hohn, T., and Walden, R. (1986). "Agroinfection," an alternative route for viral infection of plants by using the Ti plasmid. Proc Natl Acad Sci $U S A$ 83(10), 3282-6.

Gritsun, T. S., and Gould, E. A. (1995). Infectious transcripts of tick-borne encephalitis virus, generated in days by RT-PCR. Virology 214(2), 611-8.

Gronenborn, B. and Matzeit, V. (1989). Plant gene vectors and genetic transformation: plant viruses as vectors. Cell Cult Somat Cells Genet Plants 6, 69-100

Grotewold, E., Chamberlin, M., Snook, M., Siame, B., Butler, L., Swenson, J., Maddock, S., St Clair, G., and Bowen, B. (1998). Engineering secondary metabolism in maize cells by ectopic expression of transcription factors. Plant Cell 10(5), 721-40. 
Guo, H. S., Lopez-Moya, J. J., and Garcia, J. A. (1998). Susceptibility to recombination rearrangements of a chimeric plum pox potyvirus genome after insertion of a foreign gene. Virus Res 57(2), 183-95.

Gutiérrez, C., Ramirez-Parra, E., Mar Castellano, M., Sanz-Burgos, A. P., Luque, A., and Missich, R. (2004). Geminivirus DNA replication and cell cycle interactions. Vet Microbiol 98(2), 111-9.

Haas, G., Azevedo, J., Moissiard, G., Geldreich, A., Himber, C., Bureau, M., Fukuhara, T., Keller, M., and Voinnet, O. (2008). Nuclear import of CaMV P6 is required for infection and suppression of the RNA silencing factor DRB4. EMBO J 27(15), 2102-12.

Hagiwara, Y., Peremyslov, V. V., and Dolja, V. V. (1999). Regulation of closterovirus gene expression examined by insertion of a self-processing reporter and by northern hybridization. J Viro/ 73(10), 7988-93.

Hamamoto, H., Sugiyama, Y., Nakagawa, N., Hashida, E., Matsunaga, Y., Takemoto, S., Watanabe, Y., and Okada, Y. (1993). A new tobacco mosaic virus vector and its use for the systemic production of angiotensin-l-converting enzyme inhibitor in transgenic tobacco and tomato. Biotechnology (N Y) 11(8), 930-2.

Hamilton, W., Baulcombe, D. (1989). Infectious RNA produced by in vitro transcription of a full-length Tobacco rattle virus RNA-1 cDNA. J Gen Virol 70: 963-968

Hemmes, H., Lakatos, L., Goldbach, R., Burgyan, J., and Prins, M. (2007). The NS3 protein of Rice hoja blanca tenuivirus suppresses RNA silencing in plant and insect hosts by efficiently binding both siRNAs and miRNAs. RNA 13(7), 1079-89.

Hendy, S., Chen, Z. C., Barker, H., Santa Cruz, S., Chapman, S., Torrance, L., Cockburn, W., and Whitelam, G. C. (1999). Rapid production of single-chain Fv fragments in plants using a potato virus $\mathrm{X}$ episomal vector. $\mathrm{J}$ Immunol Methods 231(12), 137-46.

Hiatt, A., Cafferkey, R., and Bowdish, K. (1989). Production of antibodies in transgenic plants. Nature 342(6245), 76-8.

Hiraguri, A., Netsu, O., Shimizu, T., Uehara-Ichiki, T., Omura, T., Sasaki, N., Nyunoya,

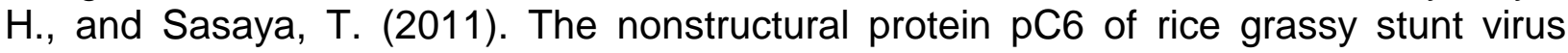
trans-complements the cell-to-cell spread of a movement-defective tomato mosaic virus. Arch Virol 156(5), 911-6.

Holt, C. A., and Beachy, R. N. (1991). In vivo complementation of infectious transcripts from mutant tobacco mosaic virus cDNAs in transgenic plants. Virology 181(1), 109-17.

Holton, T. A., and Cornish, E. C. (1995). Genetics and Biochemistry of Anthocyanin Biosynthesis. Plant Cell 7(7), 1071-1083.

Hood, E. (2002). From green plants to industrial enzymes. Enzyme Microb Tech 30, 279-83 
Hsu, C. H., Lin, S. S., Liu, F. L., Su, W. C., and Yeh, S. D. (2004). Oral administration of a mite allergen expressed by zucchini yellow mosaic virus in cucurbit species downregulates allergen-induced airway inflammation and $\lg \mathrm{E}$ synthesis. J Allergy Clin Immunol 113(6), 1079-85.

Huang, Z., Andrianov, V. M., Han, Y., and Howell, S. H. (2001). Identification of arabidopsis proteins that interact with the cauliflower mosaic virus (CaMV) movement protein. Plant Mol Biol 47(5), 663-75.

Hull, G. A., and Devic, M. (1995). The beta-glucuronidase (gus) reporter gene system. Gene fusions; spectrophotometric, fluorometric, and histochemical detection. Methods Mol Biol 49, 125-41.

Hurrelbrink, R. J., Nestorowicz, A., and McMinn, P. C. (1999). Characterization of infectious Murray Valley encephalitis virus derived from a stably cloned genome-length cDNA. J Gen Virol 80 (Pt 12), 3115-25.

Jeong, K. J., Jang, S. H., and Velmurugan, N. (2011). Recombinant antibodies: engineering and production in yeast and bacterial hosts. Biotechnol J 6(1), 16-27.

Joelson, T., Akerblom, L., Oxelfelt, P., Strandberg, B., Tomenius, K., and Morris, T. J. (1997). Presentation of a foreign peptide on the surface of tomato bushy stunt virus. $J$ Gen Virol 78 ( Pt 6), 1213-7.

Johansen, I. E. (1996). Intron insertion facilitates amplification of cloned virus cDNA in Escherichia coli while biological activity is reestablished after transcription in vivo. Proc Natl Acad Sci U S A 93(22), 12400-5.

Johansen, L. K., and Carrington, J. C. (2001). Silencing on the spot. Induction and suppression of RNA silencing in the Agrobacterium-mediated transient expression system. Plant Physiol 126(3), 930-8.

Johnson, J., Lin, T., and Lomonossoff, G. (1997). Presentation of heterologous peptides on plant viruses: genetics, structure, and function. Annu Rev Phytopathol 35, 67-86.

Kang, T. J., Kang, K. H., Kim, J. A., Kwon, T. H., Jang, Y. S., and Yang, M. S. (2004). High-level expression of the neutralizing epitope of porcine epidemic diarrhea virus by a tobacco mosaic virus-based vector. Protein Expr Purif 38(1), 129-35.

Kapila, J., De Rycke, R., Van Montagu, M. and Angenon, G. (1997). An Agrobacteriummediated transient gene expression system for intact leaves. Plant Sci 122(1), 101-8.

Kapoor, M., Zhang, L., Mohan, P. M., and Padmanabhan, R. (1995). Synthesis and characterization of an infectious dengue virus type-2 RNA genome (New Guinea C strain). Gene 162(2), 175-80.

Karasawa, S., Araki, T., Nagai, T., Mizuno, H., and Miyawaki, A. (2004). Cyan-emitting and orange-emitting fluorescent proteins as a donor/acceptor pair for fluorescence resonance energy transfer. Biochem J 381(Pt 1), 307-12. 
Kelloniemi, J., Makinen, K., and Valkonen, J. P. (2008). Three heterologous proteins simultaneously expressed from a chimeric potyvirus: infectivity, stability and the correlation of genome and virion lengths. Virus Res 135(2), 282-91.

Koes, R., Quattrocchio, F. and Mol J. (1994). The flavonoid biosynthetic pathway in plants: function and evolution. Bioessays 16 (2), 123-32.

Komori, T., Imayama, T., Kato, N., Ishida, Y., Ueki, J., and Komari, T. (2007). Current status of binary vectors and superbinary vectors. Plant Physiol 145(4), 1155-60.

Kremers, G. J., Goedhart, J., van Munster, E. B., and Gadella, T. W., Jr. (2006). Cyan and yellow super fluorescent proteins with improved brightness, protein folding, and FRET Forster radius. Biochemistry 45(21), 6570-80.

Kremers, G. J., Goedhart, J., van den Heuvel, D. J., Gerritsen, H. C., and Gadella, T. W., Jr. (2007). Improved green and blue fluorescent proteins for expression in bacteria and mammalian cells. Biochemistry 46(12), 3775-83.

Kumagai, M. H., Turpen, T. H., Weinzettl, N., della-Cioppa, G., Turpen, A. M., Donson, J., Hilf, M. E., Grantham, G. L., Dawson, W. O., Chow, T. P., and et al. (1993). Rapid, high-level expression of biologically active alpha-trichosanthin in transfected plants by an RNA viral vector. Proc Natl Acad Sci U S A 90(2), 427-30.

Lai, M. M. (2000). The making of infectious viral RNA: No size limit in sight. Proc Natl Acad Sci U S A 97(10), 5025-7.

Lakatos, L., Szittya, G., Silhavy, D., and Burgyan, J. (2004). Molecular mechanism of RNA silencing suppression mediated by 19 protein of tombusviruses. EMBO $\mathrm{J} 23(4)$, 876-84.

Lakatos, L., Csorba, T., Pantaleo, V., Chapman, E. J., Carrington, J. C., Liu, Y. P., Dolja, V. V., Calvino, L. F., Lopez-Moya, J. J., and Burgyan, J. (2006). Small RNA binding is a common strategy to suppress RNA silencing by several viral suppressors. $E M B O J$ 25(12), 2768-80.

Latham, J. R., and Wilson, A. K. (2008). Transcomplementation and synergism in plants: implications for viral transgenes? Mol Plant Pathol 9(1), 85-103.

Leffel, S. M., Mabon, S. A., and Stewart, C. N., Jr. (1997). Applications of green fluorescent protein in plants. Biotechniques 23(5), 912-8.

Li, F., and Ding, S. W. (2006). Virus counterdefense: diverse strategies for evading the RNA-silencing immunity. Annu Rev Microbio/ 60, 503-31.

Li, G., Zhang, Q. J., Zhong, J., and Wang, Y. Q. (2009). Evolutionary and functional diversity of green fluorescent proteins in cephalochordates. Gene 446(1), 41-9.

Li, X. H., and Carrington, J. C. (1995). Complementation of tobacco etch potyvirus mutants by active RNA polymerase expressed in transgenic cells. Proc Natl Acad Sci U $S$ A 92(2), 457-61. 
Lico, C., Chen, Q., and Santi, L. (2008). Viral vectors for production of recombinant proteins in plants. J Cell Physiol 216(2), 366-77.

Lim, H. S., Vaira, A. M., Domier, L. L., Lee, S. C., Kim, H. G., and Hammond, J. (2010). Efficiency of VIGS and gene expression in a novel bipartite potexvirus vector delivery system as a function of strength of TGB1 silencing suppression. Virology 402(1), 14963.

Lindbo, J. A. (2007). High-efficiency protein expression in plants from agroinfectioncompatible Tobacco mosaic virus expression vectors. BMC Biotechnol 7, 52.

Liu, L., Canizares, M. C., Monger, W., Perrin, Y., Tsakiris, E., Porta, C., Shariat, N., Nicholson, L., and Lomonossoff, G. P. (2005). Cowpea mosaic virus-based systems for the production of antigens and antibodies in plants. Vaccine 23(15), 1788-92.

Lombardi, R., Circelli, P., Villani, M. E., Buriani, G., Nardi, L., Coppola, V., Bianco, L., Benvenuto, E., Donini, M., and Marusic, C. (2009). High-level HIV-1 Nef transient expression in Nicotiana benthamiana using the P19 gene silencing suppressor protein of Artichoke Mottled Crinckle Virus. BMC Biotechnol 9, 96.

López-Moya, J. J., and García, J. A. (2000). Construction of a stable and highly infectious intron-containing cDNA clone of plum pox potyvirus and its use to infect plants by particle bombardment. Virus Res 68(2), 99-107.

Lu, R., Martín-Hernández, A. M., Peart, J. R., Malcuit, I., and Baulcombe, D. C. (2003). Virus-induced gene silencing in plants. Methods 30(4), 296-303.

Mahmoud, K. (2007). Recombinant protein production: strategic technology and a vital research tool. Res J Cell Molr Biol 1(1), 9-22.

Marillonnet, S., Giritch, A., Gils, M., Kandzia, R., Klimyuk, V., and Gleba, Y. (2004). In planta engineering of viral RNA replicons: efficient assembly by recombination of DNA modules delivered by Agrobacterium. Proc Natl Acad Sci U S A 101(18), 6852-7.

Martínez-Priego, L., Donaire, L., Barajas, D., and Llave, C. (2008). Silencing suppressor activity of the Tobacco rattle virus-encoded $16-\mathrm{kDa}$ protein and interference with endogenous small RNA-guided regulatory pathways. Virology 376(2), 346-56.

Masuta, C., Yamana, T., Tacahashi, Y., Uyeda, I., Sato, M., Ueda, S., and Matsumura, T. (2000). Development of clover yellow vein virus as an efficient, stable geneexpression system for legume species. Plant J 23(4), 539-46.

Matz, M. V., Lukyanov, K. A., and Lukyanov, S. A. (2002). Family of the green fluorescent protein: journey to the end of the rainbow. Bioessays 24(10), 953-9.

Mechtcheriakova, I. A., Eldarov, M. A., Nicholson, L., Shanks, M., Skryabin, K. G., and Lomonossoff, G. P. (2006). The use of viral vectors to produce hepatitis B virus core particles in plants. J Virol Methods 131(1), 10-5. 
Mena, M. A., Treynor, T. P., Mayo, S. L., and Daugherty, P. S. (2006). Blue fluorescent proteins with enhanced brightness and photostability from a structurally targeted library. Nat Biotechnol 24(12), 1569-71.

Merits, A., Rajamaki, M. L., Lindholm, P., Runeberg-Roos, P., Kekarainen, T., Puustinen, P., Makelainen, K., Valkonen, J. P., and Saarma, M. (2002). Proteolytic processing of potyviral proteins and polyprotein processing intermediates in insect and plant cells. J Gen Virol 83(Pt 5), 1211-21.

Messerle, M., Crnkovic, I., Hammerschmidt, W., Ziegler, H., and Koszinowski, U. H. (1997). Cloning and mutagenesis of a herpesvirus genome as an infectious bacterial artificial chromosome. Proc Natl Acad Sci U S A 94(26), 14759-63.

Mett, V., Farrance, C. E., Green, B. J., and Yusibov, V. (2008). Plants as biofactories. Biologicals 36(6), 354-8.

Meyers, B., Zaltsman, A., Lacroix, B., Kozlovsky, S. V., and Krichevsky, A. (2010). Nuclear and plastid genetic engineering of plants: comparison of opportunities and challenges. Biotechnol Adv 28(6), 747-56.

Miyawaki, A., Sawano, A., and Kogure, T. (2003). Lighting up cells: labelling proteins with fluorophores. Nat Cell Biol Suppl, S1-7.

Nguyen, A. W., and Daugherty, P. S. (2005). Evolutionary optimization of fluorescent proteins for intracellular FRET. Nat Biotechnol 23(3), 355-60.

Nishihara, M., and Nakatsuka, T. (2011). Genetic engineering of flavonoid pigments to modify flower color in floricultural plants. Biotechnol Lett 33(3), 433-41.

O'Brien, G. J., Bryant, C. J., Voogd, C., Greenberg, H. B., Gardner, R. C., and Bellamy, A. R. (2000). Rotavirus VP6 expressed by PVX vectors in Nicotiana benthamiana coats PVX rods and also assembles into viruslike particles. Virology 270(2), 444-53.

Orzaez, D., Medina, A., Torre, S., Fernández-Moreno, J. P., Rambla, J. L., FernándezDel-Carmen, A., Butelli, E., Martin, C., and Granell, A. (2009). A visual reporter system for virus-induced gene silencing in tomato fruit based on anthocyanin accumulation. Plant Physiol 150(3), 1122-34.

Patterson, G. H. (2004). A new harvest of fluorescent proteins. Nat Biotechnol 22(12), 1524-5.

Pédelacq, J. D., Cabantous, S., Tran, T., Terwilliger, T. C., and Waldo, G. S. (2006). Engineering and characterization of a superfolder green fluorescent protein. Nat Biotechnol 24(1), 79-88.

Plchova, H., Moravec, T., Hoffmeisterova, H., Folwarczna, J., and Cerovska, N. (2011). Expression of Human papillomavirus 16 E7ggg oncoprotein on $\mathrm{N}$ - and C-terminus of Potato virus X coat protein in bacterial and plant cells. Protein Expr Purif 77(2), 146-52. 
Pogue, G. P., Lindbo, J. A., Garger, S. J., and Fitzmaurice, W. P. (2002). Making an ally from an enemy: plant virology and the new agriculture. Annu Rev Phytopathol 40, 4574.

Polo, S., Ketner, G., Levis, R., and Falgout, B. (1997). Infectious RNA transcripts from full-length dengue virus type 2 cDNA clones made in yeast. $J$ Virol 71(7), 5366-74.

Porta, C., and Lomonossoff, G. P. (2002). Viruses as vectors for the expression of foreign sequences in plants. Biotechnol Genet Eng Rev 19, 245-91.

Pu, S. Y., Wu, R. H., Yang, C. C., Jao, T. M., Tsai, M. H., Wang, J. C., Lin, H. M., Chao, Y. S., and Yueh, A. (2011). Successful propagation of flavivirus infectious cDNAs by a novel method to reduce the cryptic bacterial promoter activity of virus genomes. J Virol 85(6), 2927-41.

Qu, F., Ren, T., and Morris, T. J. (2003). The coat protein of turnip crinkle virus suppresses posttranscriptional gene silencing at an early initiation step. $J$ Virol 77(1), $511-22$.

Quattrocchio, F., Wing, J. F., Leppen, H., Mol, J., and Koes, R. E. (1993). Regulatory Genes Controlling Anthocyanin Pigmentation Are Functionally Conserved among Plant Species and Have Distinct Sets of Target Genes. Plant Cell 5(11), 1497-1512.

Racaniello, V. R., and Baltimore, D. (1981). Cloned poliovirus complementary DNA is infectious in mammalian cells. Science 214(4523), 916-9.

Rai, M. and Padh, H. (2001). Expression systems for production of heterologous proteins. Curr Sci 80(9), 1121-8.

Ratcliff, F., Martin-Hernandez, A. M., and Baulcombe, D. C. (2001). Tobacco rattle virus as a vector for analysis of gene function by silencing. Plant J. 25(2), 237-45.

Rekas, A., Alattia, J. R., Nagai, T., Miyawaki, A., and Ikura, M. (2002). Crystal structure of venus, a yellow fluorescent protein with improved maturation and reduced environmental sensitivity. J Biol Chem 277(52), 50573-8.

Riechmann, J. L., Lain, S., and Garcia, J. A. (1992). Highlights and prospects of potyvirus molecular biology. J Gen Virol 73(Pt 1), 1-16.

Rizzo, T. M., and Palukaitis, P. (1990). Construction of full-length cDNA clones of cucumber mosaic virus RNAs 1, 2 and 3: generation of infectious RNA transcripts. Mol Gen Genet 222(2-3), 249-56.

Ruiz, M. T., Voinnet, O., and Baulcombe, D. C. (1998). Initiation and maintenance of virus-induced gene silencing. Plant Cell 10(6), 937-46.

Rybicki, E. P. (2010). Plant-made vaccines for humans and animals. Plant Biotechnol J 8(5), 620-37. 
Sainsbury, F., and Lomonossoff, G. P. (2008). Extremely high-level and rapid transient protein production in plants without the use of viral replication. Plant Physiol 148(3), $1212-8$.

Saitoh, H., Kiba, A., Nishihara, M., Yamamura, S., Suzuki, K., and Terauchi, R. (2001). Production of antimicrobial defensin in Nicotiana benthamiana with a potato virus $X$ vector. Mol Plant Microbe Interact 14(2), 111-5.

Satyanarayana, T., Gowda, S., Ayllon, M. A., and Dawson, W. O. (2003). Frameshift mutations in infectious cDNA clones of Citrus tristeza virus: a strategy to minimize the toxicity of viral sequences to Escherichia coli. Virology 313(2), 481-91.

Schijlen, E. G., Ric de Vos, C. H., van Tunen, A. J., and Bovy, A. G. (2004). Modification of flavonoid biosynthesis in crop plants. Phytochemistry 65(19), 2631-48.

Scholthof, H., Morris, T. and Jackson, A. (1993). The capsid protein gene of Tomato bushy stunt virus is dispensable for systemic movement and can be replaced for localized expression of foreign genes. Mol Plant Microbe Interact. 6(3), 309-22.

Scholthof, H. B., Scholthof, K. B., and Jackson, A. O. (1996). Plant virus gene vectors for transient expression of foreign proteins in plants. Annu Rev Phytopathol 34, 299323.

Schwinn, K., Venail, J., Shang, Y., Mackay, S., Alm, V., Butelli, E., Oyama, R., Bailey, P., Davies, K., and Martin, C. (2006). A small family of MYB-regulatory genes controls floral pigmentation intensity and patterning in the genus Antirrhinum. Plant Cell 18(4), $831-51$.

Senshu, H., Ozeki, J., Komatsu, K., Hashimoto, M., Hatada, K., Aoyama, M., Kagiwada, S., Yamaji, Y., and Namba, S. (2009). Variability in the level of RNA silencing suppression caused by triple gene block protein 1 (TGBp1) from various potexviruses during infection. J Gen Virol 90(Pt 4), 1014-24.

Shaner, N. C., Patterson, G. H., and Davidson, M. W. (2007). Advances in fluorescent protein technology. J Cell Sci 120(Pt 24), 4247-60.

Shcherbo, D., Merzlyak, E. M., Chepurnykh, T. V., Fradkov, A. F., Ermakova, G. V., Solovieva, E. A., Lukyanov, K. A., Bogdanova, E. A., Zaraisky, A. G., Lukyanov, S., and Chudakov, D. M. (2007). Bright far-red fluorescent protein for whole-body imaging. Nat Methods 4(9), 741-6.

Shiboleth, Y. M., Arazi, T., Wang, Y., and Gal-On, A. (2001). A new approach for weed control in a cucurbit field employing an attenuated potyvirus-vector for herbicide resistance. J Biotechnol 92(1), 37-46.

Shiboleth, Y. M., Haronsky, E., Leibman, D., Arazi, T., Wassenegger, M., Whitham, S. A., Gaba, V., and Gal-On, A. (2007). The conserved FRNK box in HC-Pro, a plant viral suppressor of gene silencing, is required for small RNA binding and mediates symptom development. J Viro/ 81(23), 13135-48. 
Shih, S. M., and Doran, P. M. (2009). Foreign protein production using plant cell and organ cultures: Advantages and limitations. Biotechnol Adv 27(6), 1036-42.

Shimomura, O., Johnson, F. H., and Saiga, Y. (1962). Extraction, purification and properties of aequorin, a bioluminescent protein from the luminous hydromedusan, Aequorea. J Cell Comp Physiol 59, 223-39.

Shivprasad, S., Pogue, G. P., Lewandowski, D. J., Hidalgo, J., Donson, J., Grill, L. K., and Dawson, W. O. (1999). Heterologous sequences greatly affect foreign gene expression in tobacco mosaic virus-based vectors. Virology 255(2), 312-23.

Sijmons, P. C., Dekker, B. M., Schrammeijer, B., Verwoerd, T. C., van den Elzen, P. J., and Hoekema, A. (1990). Production of correctly processed human serum albumin in transgenic plants. Biotechnology (N Y) 8(3), 217-21.

Smith, G. E., Summers, M. D., and Fraser, M. J. (1983). Production of human beta interferon in insect cells infected with a baculovirus expression vector. Mol Cell Biol 3(12), 2156-65.

Stanley, J. (1993). Geminiviruses: plant viral vectors. Curr Opin Genet Dev 3(1), 91-6.

Stepanenko, O. V., Verkhusha, V. V., Kuznetsova, I. M., Uversky, V. N., and Turoverov, K. K. (2008). Fluorescent proteins as biomarkers and biosensors: throwing color lights on molecular and cellular processes. Curr Protein Pept Sci 9(4), 338-69.

Steward, F., Mapes, M. and Mears, K. (1958). Growth and organized development of cultured cells II: Organization in cultures grown from freely suspended cells. Am J Bot 45(10), 705-8.

Sugiyama, Y., Hamamoto, H., Takemoto, S., Watanabe, Y., and Okada, Y. (1995). Systemic production of foreign peptides on the particle surface of tobacco mosaic virus. FEBS Lett 359(2-3), 247-50.

Takamatsu, N., Ishikawa, M., Meshi, T., and Okada, Y. (1987). Expression of bacterial chloramphenicol acetyltransferase gene in tobacco plants mediated by TMV-RNA. EMBO J 6(2), 307-11.

Taniguchi, T., Palmieri, M., and Weissmann, C. (1978). A Qbeta DNA-containing hybrid plasmid giving rise to Qbeta phage formation in the bacterial host [proceedings]. Ann Microbiol (Paris) 129 B(4), 535-6.

Toth, R. L., Pogue, G. P., and Chapman, S. (2002). Improvement of the movement and host range properties of a plant virus vector through DNA shuffling. Plant $J$ 30(5), 593600 .

Tsien, R. Y. (1998). The green fluorescent protein. Annu Rev Biochem 67, 509-44.

Turpen, T. H., Reinl, S. J., Charoenvit, Y., Hoffman, S. L., Fallarme, V., and Grill, L. K. (1995). Malarial epitopes expressed on the surface of recombinant tobacco mosaic virus. Biotechnology (N Y) 13(1), 53-7. 
Urcuqui-Inchima, S., Haenni, A. L., and Bernardi, F. (2001). Potyvirus proteins: a wealth of functions. Virus Res 74(1-2), 157-75

Vaghchhipawala, Z. E., and Mysore, K. S. (2008). Agroinoculation: a simple procedure for systemic infection of plants with viruses. Methods Mol Biol 451, 555-62.

Varsani, A., Williamson, A. L., Stewart, D., and Rybicki, E. P. (2006). Transient expression of Human papillomavirus type $16 \mathrm{~L} 1$ protein in Nicotiana benthamiana using an infectious tobamovirus vector. Virus Res 120(1-2), 91-6.

Vaucheret, H., Beclin, C., and Fagard, M. (2001). Post-transcriptional gene silencing in plants. J Cell Sci 114(Pt 17), 3083-91.

Verch, T., Yusibov, V., and Koprowski, H. (1998). Expression and assembly of a fulllength monoclonal antibody in plants using a plant virus vector. $J$ Immunol Methods 220(1-2), 69-75.

Verchot-Lubicz, J., Ye, C. M., and Bamunusinghe, D. (2007). Molecular biology of potexviruses: recent advances. J Gen Virol 88(Pt 6), 1643-55.

Verma, D., and Daniell, H. (2007). Chloroplast vector systems for biotechnology applications. Plant Physiol 145(4), 1129-43.

Verver, J., Wellink, J., Van Lent, J., Gopinath, K., and Van Kammen, A. (1998). Studies on the movement of cowpea mosaic virus using the jellyfish green fluorescent protein. Virology 242(1), 22-7.

Vogler, H., Akbergenov, R., Shivaprasad, P. V., Dang, V., Fasler, M., Kwon, M. O., Zhanybekova, S., Hohn, T., and Heinlein, M. (2007). Modification of small RNAs associated with suppression of RNA silencing by tobamovirus replicase protein. $J$ Virol 81(19), 10379-88.

Voinnet, O., Pinto, Y. M., and Baulcombe, D. C. (1999). Suppression of gene silencing: a general strategy used by diverse DNA and RNA viruses of plants. Proc Natl Acad Sci US A 96(24), 14147-52.

Voinnet, O., Rivas, S., Mestre, P., and Baulcombe, D. (2003). An enhanced transient expression system in plants based on suppression of gene silencing by the p19 protein of tomato bushy stunt virus. Plant J 33(5), 949-56.

Voinnet, O. (2008). Post-transcriptional RNA silencing in plant-microbe interactions: a touch of robustness and versatility. Curr Opin Plant Biol 11(4), 464-70.

Wagner, B., Fuchs, H., Adhami, F., Ma, Y., Scheiner, O., and Breiteneder, H. (2004). Plant virus expression systems for transient production of recombinant allergens in Nicotiana benthamiana. Methods 32(3), 227-34.

Wang, M. B., and Metzlaff, M. (2005). RNA silencing and antiviral defense in plants. Curr Opin Plant Biol 8(2), 216-22. 
Ward, C. W., and Shukla, D. D. (1991). Taxonomy of potyviruses: current problems and some solutions. Intervirology 32(5), 269-96.

Wigdorovitz, A., Perez Filgueira, D. M., Robertson, N., Carrillo, C., Sadir, A. M., Morris, T. J., and Borca, M. V. (1999). Protection of mice against challenge with foot and mouth disease virus (FMDV) by immunization with foliar extracts from plants infected with recombinant tobacco mosaic virus expressing the FMDV structural protein VP1. Virology 264(1), 85-91.

$\mathrm{Wu}$, J., and Zhou, X. (2002). Effects of replacing the movement protein gene of Tobacco mosaic virus by that of Tomato mosaic virus. Virus Res 87(1), 61-7.

Xie, Q., and Guo, H. S. (2006). Systemic antiviral silencing in plants. Virus Res 118(12), 1-6.

Yamshchikov, V., Mishin, V., and Cominelli, F. (2001). A new strategy in design of + RNA virus infectious clones enabling their stable propagation in E. coli. Virology 281(2), 272-80.

Yount, B., Denison, M. R., Weiss, S. R., and Baric, R. S. (2002). Systematic assembly of a full-length infectious cDNA of mouse hepatitis virus strain A59. J Virol 76(21), 11065-78.

Yu, B., Chapman, E. J., Yang, Z., Carrington, J. C., and Chen, X. (2006). Transgenically expressed viral RNA silencing suppressors interfere with microRNA methylation in Arabidopsis. FEBS Lett 580(13), 3117-20.

Yusibov, V., Shivprasad, S., Turpen, T. H., Dawson, W., and Koprowski, H. (1999). Plant viral vectors based on tobamoviruses. Curr Top Microbiol Immunol 240, 81-94.

Zhang, C., Bradshaw, J. D., Whitham, S. A., and Hill, J. H. (2010). The development of an efficient multipurpose bean pod mottle virus viral vector set for foreign gene expression and RNA silencing. Plant Physiol 153(1), 52-65.

Zhang, F., and Simon, A. E. (2003). A novel procedure for the localization of viral RNAs in protoplasts and whole plants. Plant J 35(5), 665-73.

Zhang, X., Yuan, Y. R., Pei, Y., Lin, S. S., Tuschl, T., Patel, D. J., and Chua, N. H. (2006). Cucumber mosaic virus-encoded $2 b$ suppressor inhibits Arabidopsis Argonaute1 cleavage activity to counter plant defense. Genes Dev 20(23), 3255-68. 


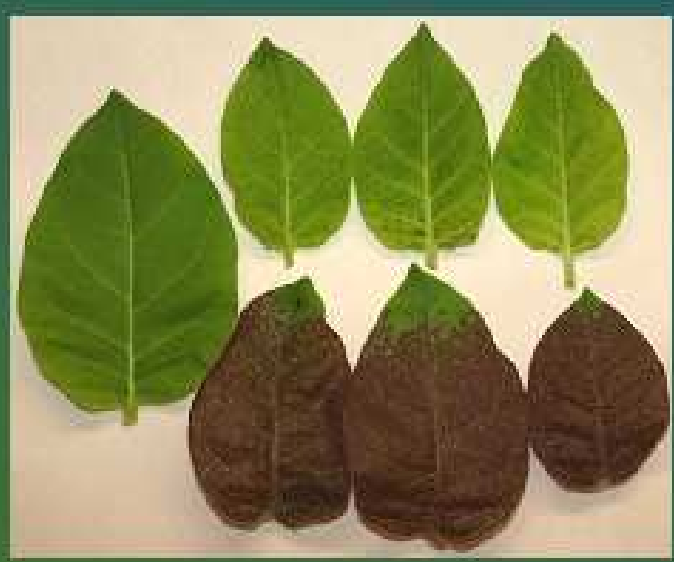

